Bartosz Czepil / Wojciech Opioła

\title{
Ethnic diversity and local governance quality
}

\section{The case of Opole Province in Poland}

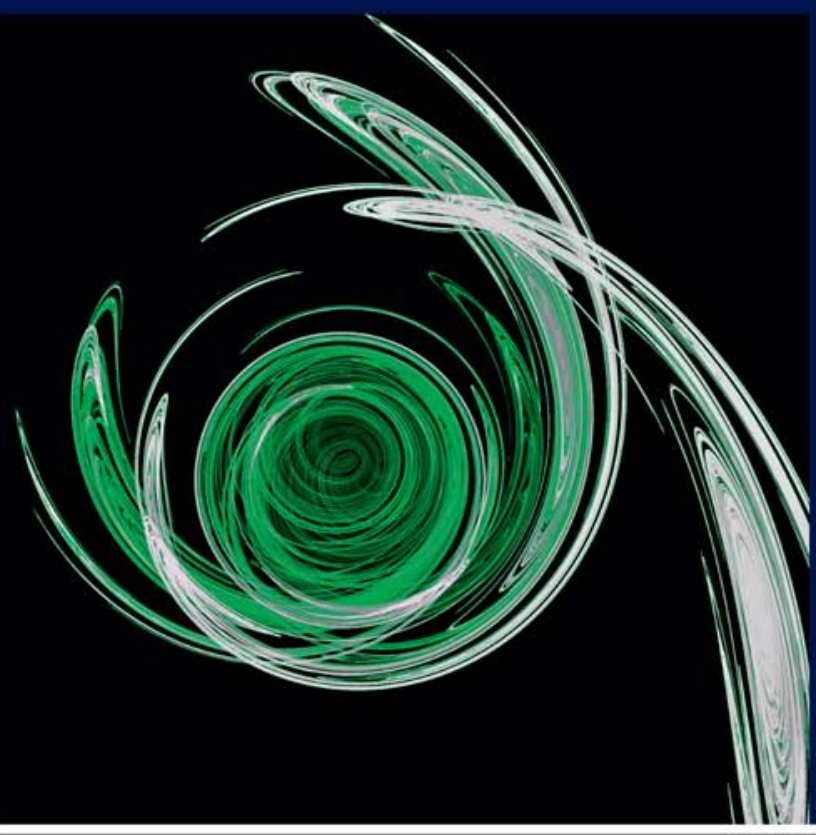




\section{Bartosz Czepil / Wojciech Opioła \\ Ethnic diversity and local governance quality}

The book is devoted to relations between the ethnic diversity and the quality of governance at the local level. Opolskie province in Poland is a case for explaining this interdependence. That is because of its history of multiculturalism and the present state of its ethnic diversity. The important feature of this region is, that nearly half of the communes is ethnically homogenous when the rest is ethnically diversified with a strong position of German and Silesian minorities. The preliminary assumption was, that the quality of governance would be higher in communes characterized by ethnic diversity. On the basis of the nested analysis method, authors conducted quantitative and qualitative analysis.

\section{The Authors}

Bartosz Czepil is a political scientist and sociologist, assistant professor at University of Opole, Poland.

Wojciech Opioła is a political scientist, assistant professor at University of Opole, Poland and the editor-in-chief of „Pogranicze. Polish Borderlands Studies“ peer-reviewed journal. 
Ethnic diversity and local governance quality 


\section{STUDIES IN POLITICS, SECURITY AND SOCIETY}

Edited by Stanisław Sulowski

Faculty of Political Science and International Studies

University of Warsaw

VOLUME 29

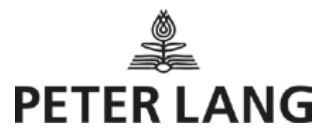


Bartosz Czepil / Wojciech Opioła

\section{Ethnic diversity and local governance quality}

The case of Opole Province in Poland

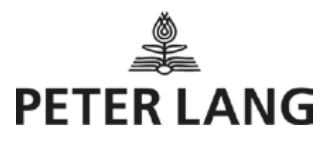




\section{Bibliographic Information published by the Deutsche Nationalbibliothek}

The Deutsche Nationalbibliothek lists this publication in the Deutsche Nationalbibliografie; detailed bibliographic data is available in the internet at http://dnb.d-nb.de.

Library of Congress Cataloging-in-Publication Data A CIP catalog record for this book has been applied for at the Library of Congress.

This publication was financially supported by the National Science Centre (grant no. UMO-2015/19/D/HS5/02566).

Printed by CPI books GmbH, Leck

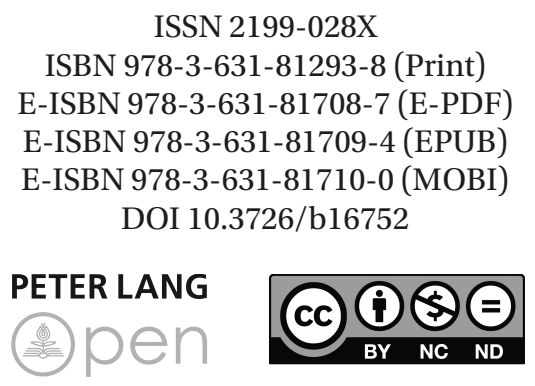

Open Access: This work is licensed under a Creative Commons Attribution Non Commercial No Derivatives 4.0 unported license.

To view a copy of this license, visit https://creativecommons.org/licenses/by-nc-nd/4.0/

(C) Bartosz Czepil / Wojciech Opioła, 2020

Peter Lang - Berlin · Bern · Bruxelles · New York · Oxford · Warszawa $\cdot$ Wien

This publication has been peer reviewed. www.peterlang.com 


\section{Contents}

Introduction

I. Research methodology .................................................................. 13

1 The meaning of the project ................................................................ 13

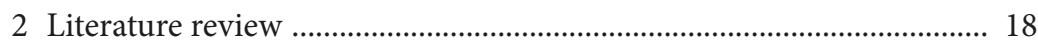

3 The concept and the main research stages ......................................... 25

II. Ethnic diversity and quality of governance.

Conceptualization and measurement at the commune level

1 Commune in the Polish political system ................................................. 29

2 Ethnic diversity .......................................................................................... 35

The number of groups ............................................................................... 36

A group differentiation basis ................................................................... 38

Group size ratios ....................................................................................... 39

Dynamics of changes .................................................................................. 40

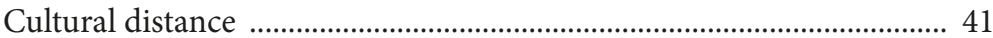

Method of measurement ............................................................................... 42

3 Quality of governance ......................................................................... 43

\section{A characterization of the Opolskie province. Cultural} diversity as a distinctive feature ...................................................... 63

1 The Opolskie province as a region ............................................................ 63

2 The place of the Opolskie province in the European Governance Quality Index ......................................................................................... 66

3 The Opolskie province's history of multiculturalism .............................. 70

4 The present state of multiculturalism in Opole Silesia .......................... 77 


\section{Quantitative analysis: the results of measurements and their} interpretation

1 General characteristics of selected communes ...................................... 81

2 Results of the governance quality measurement ................................... 82

3 Correlation analysis ........................................................................... 90

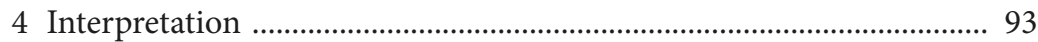

V. Qualitative analysis. Case studies of selected communes .... 97

1 Kolonowskie ..................................................................................... 102

Governance quality profile ...................................................................... 102

Geographic and demographic position ................................................ 104

Economy .......................................................................................... 105

Specific features in the material, symbolic, and identity-related

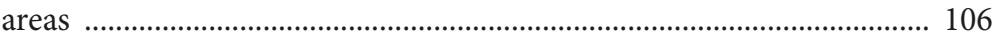

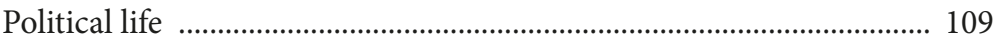

Attempt to explain the governance quality profile ................................. 114

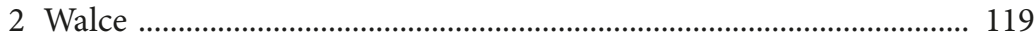

Governance quality profile ..................................................................... 119

Geographic and demographic position .................................................. 120

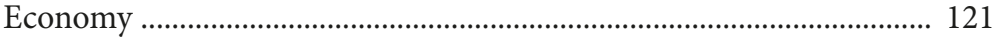

Specific features in the material, symbolic, and identity-related areas ................................................................................... 121

Political life ................................................................................. 122

Attempt to explain the governance quality profile ............................... 124

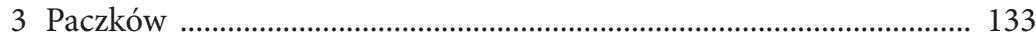

Governance quality profile ....................................................................... 133

Geographic and demographic position ................................................ 135

Economy .................................................................................................. 136

Specific features in the material, symbolic, and identity-related areas

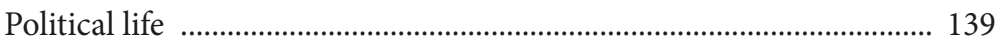

Attempt to explain the governance quality profile ................................ 141 


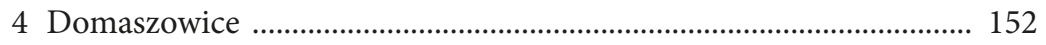

Governance quality profile ................................................................. 152

Geographic and demographic position ................................................. 155

Economy ................................................................................................. 155

Specific features in the material, symbolic, and identity-related

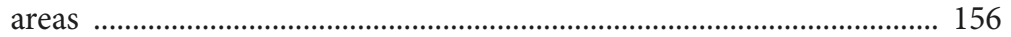

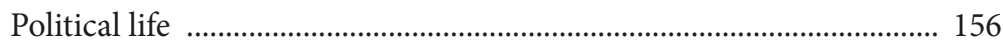

Attempt to explain the governance quality profile ................................ 162

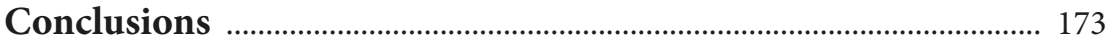

Annex 1: A table of the governance quality indexes ...................... 179

Annex 2: A detailed description of the particular governance quality indexes ..................................................................... 183

Annex 3: The CAWI questionnaire (sent on 7 July 2017) ............. 205

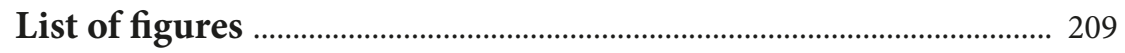

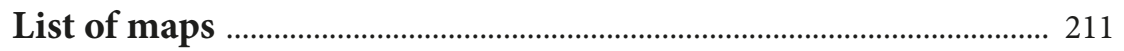

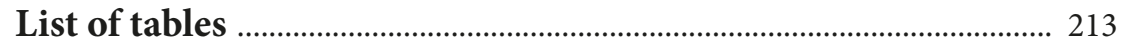

List of interviews ............................................................................... 215

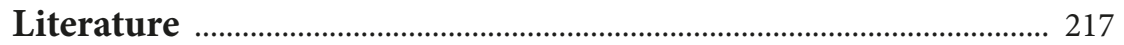





\section{Introduction}

This book is devoted to relations between the ethnic diversity of the region and the quality of governance at the local level. Opolskie province in Poland is a case for explaining this interdependence, because of its history of multiculturalism, its changes after 1946, and the present state of its ethnic diversity. The important feature of the analyzed region is, that nearly half of the communes is ethnically homogenous when the rest is ethnically diversified with a strong position of German and Silesian minorities.

Since the beginning of the 1990s, under the influence of international organizations promoting the cause of global development, the notion of good governance has become an important category in both the normative and analytical dimensions. The World Bank, the International Currency Fund, the International Monetary Fund, the Organization for Economic Co-operation and Development, and the United Nations Organization regard so-called good governance as a prerequisite for the effective use of development assistance and a foundation for social and economic development (Khan 2016: 4-5). Simultaneously, as Tadeusz Borys notes after reviewing various concepts of good governance, they are deprived of a universal character because they usually concern the national level, "with marginal references to the local level" (Borys 2014: 61). This is also noticed by Grzegorz Kula, according to whom "important aspects of good governance refer to the very structure of a state, its political system and traditions, therefore, it is difficult to assess them at the levels lower than the central one" (Kula 2013: 284). Simultaneously, Kula observes that "theoretically, the shorter the distance between authorities and citizens, the easier it is to assess the quality of governance" (Ibidem 286). It seems therefore that the problem of measuring the quality of governance should be less complicated at the level of local government than at the central level. Not only the alleged ease of access to information on activities of local authorities but also the fact that the individual directly experiences the result of the governance process at this level determine the importance of research on the quality of governance at the commune level. According to the authors, this position is supported by the still valid opinion of Alexis de Tocqueville on the special role of commune institutions which "for freedom, are what primary schools are for science: they cause freedom to become available to the people, allow it to develop a taste for its practice, and make it accustomed to use it" (De Tocqueville 2005: 57). Thus, the commune has an enormous potential for political socialization consistent with 
the spirit of the international standards of good governance, but it is also a unit in which, because of its sociological features, there exist considerable opportunities for the implementation of such standards.

Offered to readers, this book is the crowning element of the research project carried out by the authors in the years 2016-2019 thanks to a grant obtained from the Polish National Science Centre. The original idea motivating the authors was to combine their respective research experience in the fields of local politics, borderland issues, and multiculturalism of the Opolskie province (Opioła and Trzcielińska Polus 2013; Ganowicz and Opioła 2017; Opioła 2014a; 2014b; 2015) as well as governance quality and anti-corruption (Czepil 2014; 2015; 2016). This bore fruit in the form of a proposal to examine the quality of governance at the commune level and to diagnose to what extent and in what manner local governance quality could be influenced by the ethnic diversity of a particular commune's inhabitants. As the area of their research, the authors selected the Opolskie province, where a half of the communes are inhabited by German and Silesian communities.

At the beginning the authors were also interested in the issue of the strength of a local civil society. However, during the course of the project the decision was made - in accordance with the practice of research on governance quality - to treat a civil society as one of the dimensions of governance quality (participation).

In accordance with the adopted research method (nested analysis), the authors first conducted a statistical analysis based on the existing data (supplemented with a questionnaire survey). On the basis of the quantitative data, four communes were selected for the next stage of a qualitative analysis with a view to a more thorough exploration of possible relations between ethnic diversity and governance quality.

The theoretical and methodological guidelines for the research were developed in 2015. In 2016, following project reviewers' suggestions, the authors simplified some elements of the research process. The operationalization of the basic research categories, the selection of indicators, and the preparation of governance quality and ethnic diversity indexes, as well as a statistical analysis were carried out in 2016 and 2017. A CAWI questionnaire was administered in the middle of 2017 and the period from June 2018 to June 2019 was devoted to qualitative research conducted in the four communes of the Opolskie province: Domaszowice, Kolonowskie, Paczków and Walce. Simultaneously, from the spring of 2018 the authors were working on the final version of a research report in the form of this very book.

The book consists of five chapters. As this publication is a research report, there are considerable differences in the volumes of the particular chapters, but 
the authors decided to maintain the originally adopted structure of the book consistent with the logic of the conducted research. Chapter one includes a presentation of the research problem, research questions and hypotheses. It also contains a review of the literature on relations between ethnic diversity and quality of governance, as well as certain preliminary assumptions/dilemmas allowing the authors to place the research in a broader context. The final part of chapter one describes the subsequent research stages and defines the basic notions applicable to the reality under examination, i.e. ethnic diversity and governance quality.

Chapter two describes the theoretical background for the conducted research. It starts with a general description of the Polish commune, which constitutes a unit of analysis in the research. It is followed by an operationalization of the notion of "ethnic diversity" and deliberations on issues related to the measurement of ethnic diversity that the authors had to deal with. The last part of chapter two contains an operationalization of the notion of "governance quality" and a presentation of the authors' original local level governance quality index.

Chapter three is devoted to a description of the Opolskie province, in particular its multiculturalism as a feature distinguishing it from the other regions of Poland. It also contains a short historical analysis of the multiculturalism and borderlandness of the region as well as a comparison between its social and economic situation and those of the other Polish provinces.

Chapter four constitutes a presentation of the results of the quantitative analysis conducted by the authors. It contains a part of the collected statistical data, an analysis of correlations between the governance quality index and the level of ethnic diversity, as well as first conclusions and additional questions that arose in consequence of the conducted data analysis.

The longest in the book, chapter five presents four case studies based on the selected communes of the Opolskie province. It describes the method of selecting cases for the qualitative analysis, the procedures of collecting, analyzing and processing information, as well as four case studies based on one predetermined scheme.

The book ends with conclusions constituting responses to the questions posed and hypotheses proposed in its introductory part, as well as additional observations made during the course of the project. The final part of the book contains enclosures, lists of tables and figures, as well as a list of references.

From the perspective of the four years spent on the performance of the research described in the book, the authors regard it as an extremely difficult task. Being aware that the subject matter of the research belongs to one of the most inconclusive areas of research in social sciences (additionally, the manner of presentation depends on the discipline represented by a given researcher, and 
a particular issue can be studied by political scientists, sociologists, economists, and representatives of other disciplines), we would like to thank all those people who contributed to the final shape of the presented research. The anonymous reviewers of our research project proposal submitted (twice) to the National Science Centre. Our colleagues at the University of Opole, who during - frequently heated - discussions helped us to understand better the subject matter of our research, particularly Błażej Choroś, Borys Cymbrowski, Ewa Ganowicz, Danuta Kisielewicz, Aleksander Kwiatek, Marek Mazurkiewicz, Kamil Minkner, Magdalena Ozimek-Hanslik, and Krzysztof Zuba. The participants of the conferences (held in Luxembourg, Warsaw, Kamień Śląski, Šiauliai, Kiev) during which the authors discussed the assumptions for, and the results of, the research. The anonymous reviewers of the authors' articles and the editors of academic periodicals and collective monographs in which the authors published partial results of their research. And last but not least, the reviewers of this book (and its Polish language version) and all those involved in the publication process. 


\section{Research methodology}

The research problem of the study presented herein is the relation between the ethnic diversity of the Opolskie province and the quality of governance in particular communes of the region. The objective of the research project is a diagnosis of potential relations between this diversity and the quality of governance at the local level. The main research question to which the authors would like to provide an answer concerns the problem whether multi-ethnicity is a factor strengthening the quality of governance or rather a factor hindering the development of this aspect of the public sphere. To answer this question, it is necessary first to provide answers to several detailed questions: Is the level of the quality of governance in the Opolskie province communes with ethnic diversity different from that in ethnically homogeneous communes? How can diversity influence the quality of governance? What is the character of the relation and what are the social and political mechanisms through which the two aspects influence each other? Based on the above-mentioned questions, we want to present the following research hypotheses:

1. The quality of governance is higher in the Opolskie province communes with ethnic diversity in comparison to the quality of governance in the ethnically homogeneous communes.

2. The sense of identity of the minority in the Opolskie province (the German minority, citizens declaring their Silesian national identity) and their political interests are factors contributing to the higher quality of governance in the ethnically diversified communes.

\section{The meaning of the project}

The source of inspiration for the proposed study has been Robert Putnam's study conducted in Italy in which he examined interregional differences in the dimension of civil participation models and institutional effectiveness (Putnam 1995). This perspective induced the project's authors to ask questions concerning the influence of ethnic diversity in the Opolskie province on the differences occurring in particular between the eastern and western parts of the province (in the study, we do not take into consideration the influence of the Polish-Czech border area in the southern part of the province). Unlike in Putnam's research, in our study it is the factor of national and ethnic diversity that we consider to be a major variable explaining the hypothetical differences in the quality of 
governance. The level of analysis is also different: while Putnam focused on differences between regions all given the same formal institutional structures of representation and their different cultural uses of them, the project's authors are interested in a lower, local level of exploration and the ongoing elaboration of different formal and informal cultural regional representation structures over time as well.

At the provincial level, according to the data from national census carried out in 2011, the Opolskie province was inhabited by 895,000 people declaring Polish nationality ${ }^{1}, 106,000$ people declaring Silesian nationality, and 78,000 declaring German nationality. Furthermore, the census failed to establish the identity of over 22,000 people. Also, the number of people of Romany nationality was established at around 200 (according to the estimates of the Provincial Office, there are between 1500 and 2000 Romanies in the province), and 2700 people declared nationality other than Polish, Silesian, German or Romany. Analyzing the region with respect to minority group, we can divide the province into two parts: the eastern part with a considerable percentage of Germans and Silesians, and the western part, practically without any larger groups representing ethnic minorities.

The study is in line with the research tradition of the Opolskie province, but also goes beyond its dominant perspective. The fundamental constitutive elements of researches conducted by political scientists in the Opolskie province are the functioning of the German minority in the region and the consequences of the post-war population relocations (cf. Berlińska 1999; Lis 1993; 2013; Madajczyk 2001; Trosiak 2013; Trzcielińska-Polus 1999) ${ }^{2}$. In a previous research focusing on the Opolskie province, two significant patterns have been observed that should be taken into consideration in the context of the presented research problem:

1. Analyzing the Opolskie province as an ethnically and culturally diversified region and as a social borderland. However, one should be aware of the multidimensional character of such an approach. The borderland character of the Opolskie province is not only determined by the province's location at the state border (the Polish-Czech border) but also - and even to a significant degree [1] the presence of a large number of the German minority members in the

1 In the case of persons declaring a double identification, they were classified as being of the first declared national identification.

2 The post-war population transfers took place at the former territory of the Central European countries, mostly affected current territory of Poland (former Germany) and Ukraine (former Poland). Between 1944 and 1951 in all Central Europe about 20 million of people left homes, because of forced transfers. 


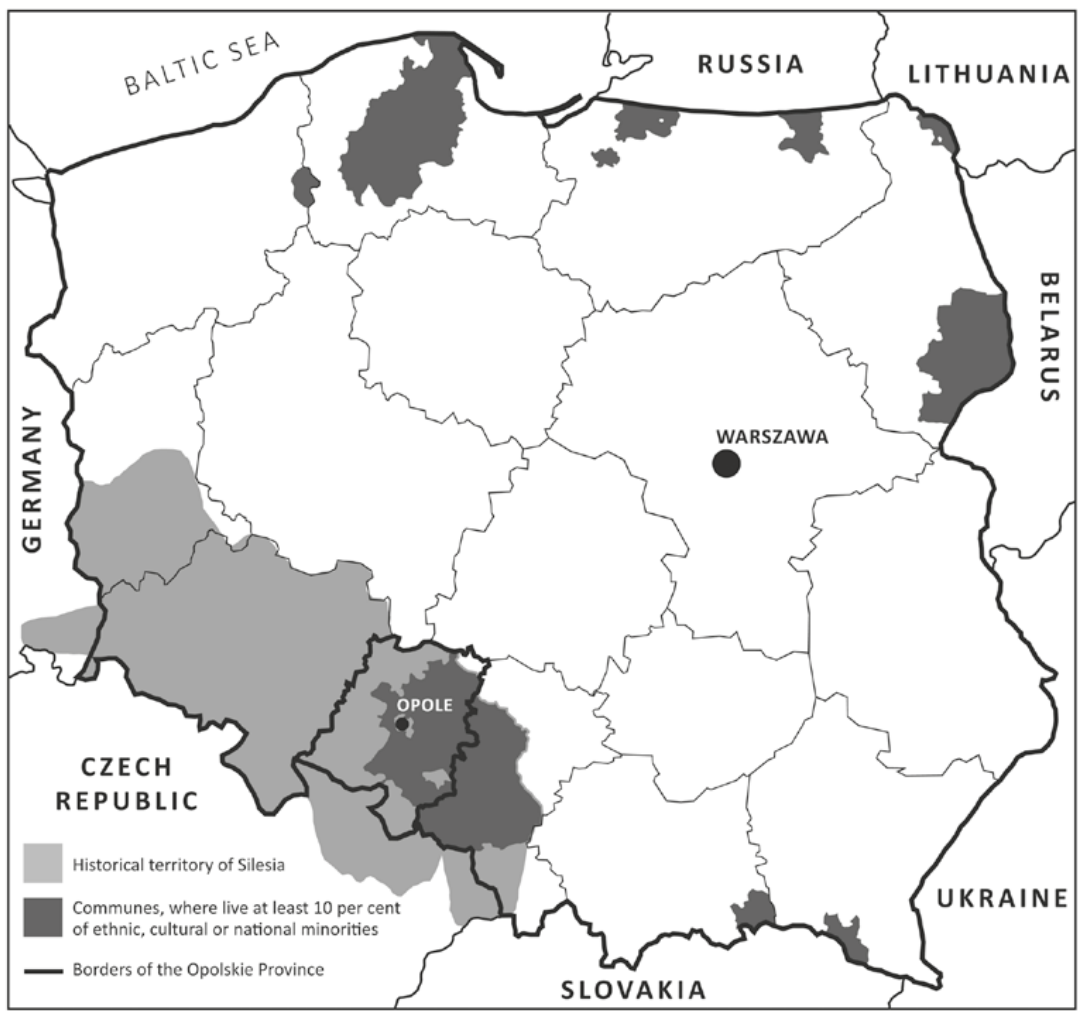

Map 1. Minorities in Poland. Source: the authors' own work.

region (the Polish-German social borderland); [2] the historical division still existing in the material culture - into "Germany" (the Opole Regency) and "Poland" (the upper Prosna River basin area: Praszka, Byczyna); [3] the "topographic and social" borderland (understood as the clash of the Polish immigrants, "Prussian" infrastructure, and symbolical capital); [4] "Polish multiculturalism" caused by the post-war migrations and the intermingling of the Polish speaking population from culturally different regions of the Second Polish Republic (1918-1939). The division into the German minority and the Polish majority is thus just one of several possible dimensions of the analysis.

2. In the Opolskie province, just like in the Śląskie and Dolnośląskie provinces, the phenomenon of Silesian self-identification of the population has 


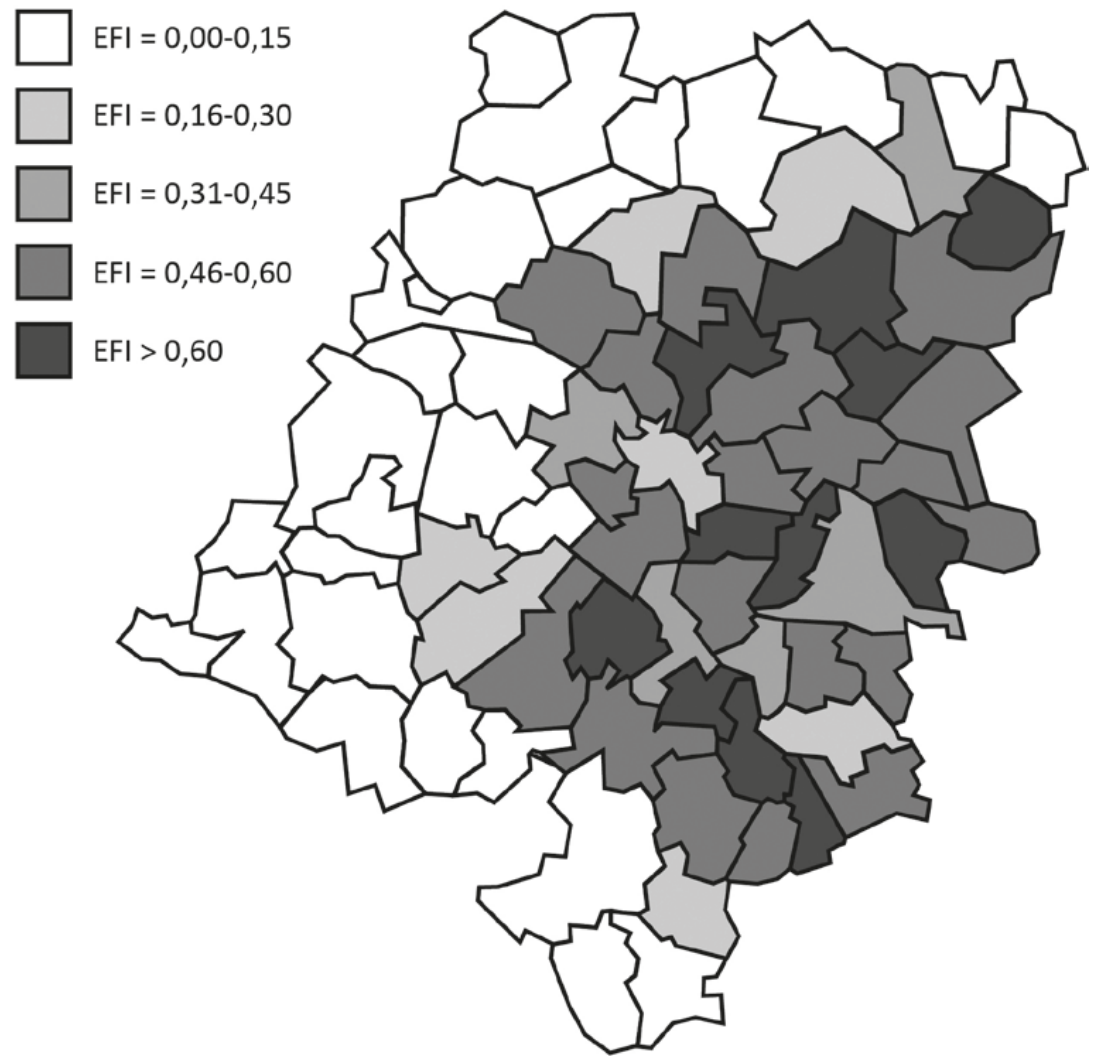

Map 2. Ethnic diversity of Opolskie province. Source: the authors own work.

intensified in the recent 15 years $^{3}$. It is particularly worth analyzing the identification of the Silesian people in the context of identification with the German nationality - in the latest census a significant decrease of German nationality declarations was observed with a simultaneous considerable increase of Silesian identifications. The process needs to be thoroughly analyzed at the commune, and even village level. It is of great importance, since the German minority is politically empowered (and characterized by a high level of social

3 The Silesian separatism developed in the late 19th century as a regional defense against both Prussian/German as well as Polish nationalization projects. 
life institutionalization), while the Silesians have only just started fighting for their political representation ${ }^{4}$.

In view of the above observations, it can be assumed that the Opolskie province is a specific region whose primary characteristic is the tradition of multiculturalism and the still present and experienced ethnic diversity (see Map 2). This state of affairs offers a natural possibility to explore the relations between diversity and the quality of governance at the local level.

The presented research project combines two aspects which are becoming more and more important in the light of contemporary civilizational transformations. The first aspect concerns the multiculturalism of regions and the development of regional identities, and it is in line with the current research agenda in the scope of regional policy in Europe (cf. Jeffery 2015; Mihajlović 2014; Paasi 2013; Riding and Jones 2017; Vainikka 2014). In this context, the project is a significant element broadening the knowledge of the functioning of multicultural regions on the continent. Processes similar to those observed in other EU regions occur also in the Opolskie province: migrations, growing economic disparity and social marginalization, increasing importance of double (national and regional) identification, decreasing interest in politics at both the European and national levels, and growing citizens' participation in the regional and local dimensions. The last of the mentioned elements refers to the other aspect of the proposed study, i.e. a growing interest in the civil society and the quality of governance, and relations between these variables are more and more frequently emphasized. The following issues are of particular interest: social capital, trust, political participation being analyzed as phenomena connected with the quality of governance (cf. Działek 2011; Kaufman, Kraay, Mastruzzi 2007; Łopaciuk-Gonczaryk and Hardt 2013; Newton 2001; Portes 1998; Putnam 1995; 2001; Rothstein 2011; Wilkin 2013). In the study, we want to connect these aspects and ask questions about the cause-and-effect relations between the region's multiculturalism and the power of its institutions. In social sciences, there have been numerous studies and theories related to this topic; in some of them Silesia has been considered a unit of analysis (Berlińska 1999; Cybula and Majcherkiewicz 2005; Szczepański 1998). One of the basic relations pointed out by researchers is the negative influence of ethnic diversity on the level of bridging social capital, social cohesion, quality of life or welfare,

4 And an institutional expression of these aspirations is the registration of three political parties representing the Silesians in 2018: Śląska Partia Regionalna, Ślonzoki Razem and Regionalna Mniejszość z Większością. 
which results, for instance, from a lower level of trust in representatives of ethnic groups other than one's own and a higher level of social capital and trust in ethnic representatives of one's own group. (cf. Alesina et al. 2003; Dinesen and Sønderskov 2018; Putnam 2007; Rothstein and Charron 2014; Schaeffer 2013; Wallman Lundåsen and Wollebæk 2013, Wright and Bloemraad 2012).

\section{Literature review}

Two works published in the recent years deserve special attention in this research area. One of them is an analysis by Alberto Alesina, Arnaud Devleeschauwer, William Easterly, Sergio Kurlat and Romain Wacziarg concerning the relation between ethnic fractionalization and the social and economic development of states (Alesina et al. 2003), while the other is a lecture by Robert Putnam of 2007 on the influence of ethnic diversity on civic life in the United States (Putnam 2007).

Alesina's work's contribution to the research on relations between ethnic diversity and the quality of governance consists first of all in the development of a universal ethnic fractionalization index (EFI) by means of which comparative quantitative studies can be easily conducted. This index, which is also used in our analysis, takes into consideration two variables: the number of ethnic groups in the population and the proportions of the sizes of particular groups (Alesina et al. 2003: 158-159). Most of the subsequent works use the EFI to measure ethnic diversity. Unlike the previously used index of ethnolinguistic fractionalization (ELF), the EFI allows the measurement of fractionalization of groups with different characteristics other than language only (such as national and ethnic identification, religion; cf. Fearon 2003).

Nevertheless, the contribution of the previous researches based on the ELF is significant, in particular in explaining the so-called new liberal dilemma. Whereas the primary objective of liberal democracies is to develop conditions for the existence and respect of diversity, the very diversity seems to decrease citizens' inclination to participate in public life and thus undermines the social foundations of the effective functioning of democratic institutions (Schaeffer 2013). Rafael La Porta, Florencio Lopez-de-Silanes, Andrei Shleifer and Robert Vishny (1999), based on data collected in 161 countries, explain that in ethnolinguistically homogeneous countries the quality of governance is higher than in countries diversified in this respect. Along with the growth of ethnic diversity, the level of state interventionism also rises, while the efficiency and quality of provided public services decrease. Exclusion or discrimination of ethnic minorities in their access to public services is a common phenomenon (Ibidem: 1220). Similar conclusions can be drawn from the research conducted by William Easterly and 
Ross Levine, who analyzed African countries and explained that the high level of ethnic diversity accounted for their political instability and a low level of provided public services (Easterly and Levine 1997).

Simultaneously, there were also studies criticizing the fractionalization index as not being the most adequate tool for examining cause-and-effect relations between multiculturalism and political phenomena or processes. For instance, Paul Collier in his article (2001) and later in the book (2007), failed to find such a relationship to being in a conflict trap related to ethnic diversity. It was only one kind of ethnic diversity that was socially/politically/violently destabilizing: "dominance" of one large ethnic minority in a mostly homogeneous country. Strong ethnic diversity was hardly a problem, but the medium level of diversity could be. James Fearon (2003) as well as Jose Montalvo and Marta Reynal-Querol (2005) observed that not just ethnic diversity, but cultural distance or polarization between ethnic groups within a particular community had much more significant explanatory potential. However, the polarization index proposed by Reynal-Querol ( $R Q$ index, Reynal-Querol 2002) was not as commonly accepted as the fractionalization index in social studies.

It is worth mentioning that in the case of the research presented in this book, we assume that the polarization cultural distance of all analyzed units taken into consideration by us is identical, as representatives of the same three ethnic groups live in each of the analyzed communes, but in different proportions. Therefore, in this case the fractionalization index is the right criterion of ethnic diversity.

While in the above mentioned studies scientists, chiefly economists, focused on cause-and-effect relations between a high level of ethnic diversity and a low level of the quality of governance and welfare, in subsequent studies scholars started searching for answers to the question whether ethnic diversity was the only basic element of differences in that respect. Paul Collier argued that ethnic diversity had a much more negative impact in non-democratic regimes, while stable democratic countries coped much better with their communities' multiculturalism (Collier 2000). Jan Delhey and Kenneth Newton (2005) observed the direct influence of ethnic homogeneity on a higher level of trust and the indirect influence on the quality of governance, life and economic egalitarianism. Scholars also started wondering whether, and in which conditions, ethnic diversity could be a factor strengthening the governance process. According to Robert Putnam, in medium- and long-term perspectives, an ethnically diversified community could establish new forms of social solidarity and intra-ethnic trust (Putnam 2007). Presented during the Johan Skytte Prize Lecture, this thesis soon became a very influential point of reference for scholars examining relations between multiculturalism and the social and political stability of contemporary communities. 
In his work, Putnam focuses on numerous positive and negative aspects of growing ethnic diversity. Without referring to all examples presented therein, let us concentrate on the part of the research which concerns diversity at the local level. Basing on data from the Social Capital Community Benchmark Survey, Putnam points out that local heterogeneous communities in the United States are characterized by a lower level of trust in local authorities local media, lower election frequency (but simultaneously higher level of interest in politics), lesser inclination to participate in joint projects for the benefit of the local community, lower density of friendship networks, lower quality of life, greater importance of television as the basic source of entertainment (Putnam 2007: 149-150). Still, justifying his thesis of the positive effects of multiculturalism in a long-term perspective, Putnam points out that the history of the American society is the history of a multinational community which in the first half of the 20th century and right after WWII replaced the dominant ethnic nationalisms with civic nationalism (Americanism, ibidem: 162-163). The American society's ethnic diversity is a multilevel diversity comprising the heritage of three processes: mass migration in the 17th, 18th, and 19th centuries, primarily from European countries, slavery and, contemporary immigration from Latin America, Asia and the countries of Middle East. The first of the above mentioned processes is a confirmation of the thesis of possible long-term development of strong social capital and an active civil society in multinational communities. This factor - the history of long lasting coexistence of a multi-ethnic community - seems also to be of importance in the case of the communes of the Opolskie province, whose ethnic structures were formed basically 70 years ago.

Putnam's theses soon started to be verified in other regions of the world. Maurice Gesthuizen, Tom van der Meer and Peer Scheepers (2008) determined that in the case of European democracies, such factors as economic inequalities and consolidation of a democratic regime in a state (the longer uninterrupted history of democracy, the higher the level of social capital) had much stronger influence on diversification in social capital among the European states continent than ethnic diversity. A similar relation was not found in another comparative study of European countries, either (Hooghe, Reeskens, Stolle and Trappers 2009). Analyzing the British society at the level of neighborhood communities, Patrick Sturgis, Ian Brunton-Smith, Sanna Read and Nick Allum (2011) did not show any statistically relevant cause-and-effect relations between ethnic diversity and social trust.

What is also worth mentioning is an interesting critique of Putnam's approach to the study of cause-and-effect relations between ethnic diversity and social capital. According to Alejandro Portes, the variables analyzed by Putnam 
(social trust, civil society, ethnic diversity) correlate, but it cannot be stated that one is the consequence of another; they rather affect one another (Działek 2011; Portes 1998; Portes and Vickstrom 2011). Portes and Vickstrom also reverse the argument's logic, and propose the thesis that it is the high quality of governance that can be the factor decreasing the negative effects of ethnic diversity and increasing the level of social trust (Portes and Vickstrom 2011: 476).

As it ensues from the previously presented review of the literature on the subject, most of the studies are comparative analyses at a national level. The basic dependent variable in most of the studies is also social capital or social cohesion; the quality of governance or civil society appears only as potential consequences. There are considerably fewer analyses conducted at a local level. These comprise the above quoted Putnam (2007) and Sturgis with his team (2011). An interesting example is the study on the influence of ethnic diversity on citizenship and an inclination to act collectively for the benefit of the local community conducted in rural settlements in Nepal (Baland, Bardhan, Das, Mookherjee and Sarkar 2007), in which no influence of diversity on the level of responsibility for the common good was shown. Many valuable guidelines can be found in the recent studies by Ruud Koopmans and Merlin Schaeffer on relations between ethnic diversity and social cohesion in the local urban communities in France, Germany and the Netherlands (Koopmans and Schaeffer 2016). The scholars confirmed the existence of a negative cause-and-effect relation between a community's heterogeneity and social cohesion; they simultaneously proved that negative effects could be mitigated by conducting an appropriate immigration policy (integrative rather than assimilative).

The cultural specificity of the Opolskie province will be used here to verify the theoretical statements concerning relations between ethnic diversity and the quality of governance. Furthermore, it will be a study of the quality of governance in which the Opolskie province is not considered (which seems a dominant practice) to be a homogeneous entirety compared to other provinces (cf. Przewłocka et al. 2013; Skrzypiec 2013; Wilkin 2008), but rather a culturally heterogeneous region where it is possible to identify processes, phenomena and differences which fall outside analyses taking into consideration data aggregated at the provincial level. Thus the multicultural specificity of the Opolskie province and its hypothetical influence on the quality of governance in the region will be "discovered" for scholars interested in such relations. Finally, research results will allow an empirically consolidated reference to many common beliefs concerning the differences between the western and eastern part of the Opolskie province, which are stereotyped, and which are explained in third chapter. 
Relations between the multiculturalism of the Opolskie province and the quality of governance is a peripheral area of interest among researchers. The researchers who dealt with the issue of multiculturalism of the province did not focus on its relations with the quality of governance and, in fact, did not use this notion in their work. However, their research contains some themes which make it possible to draw some conclusions on relations between the multiculturalism of the province and phenomena relevant for the study of the quality of governance (e.g. the unique character of local social capital, participation, civil society, the quality of regional and local institutions). Therefore, in the subsequent part, we try to focus on these threads and conclusions of the research that concern relations between multiculturalism and phenomena determining the quality of governance.

In the studies dedicated to the first decades after the mass relocation campaign, the researcher drew attention to differences among the three "interest groups", i.e. settlers, relocatees from the Eastern Borderlands, and autochthons, and competition among them. Settlers were perceived as the most dynamic group, while relocatees and the Silesian population were a socially disadvantaged group. In the case of Silesians, it was the result of their instrumental treatment by the authorities of the People's Republic of Poland and discrimination with respect to access to public services as well as positions and jobs in local governing structures. Meanwhile, the social disadvantage of Borderlanders resulted from the sense of temporariness, the loss of their homelands, and negative stereotypes (Madajczyk and Berlińska 2008: 526). These groups - Silesians and relocatees from the Eastern Borderlands - were also perceived as competing against each other in the field of culture. On the other hand, settlers, who usually came to Opole Silesia voluntarily, were defined in opposition to Borderlanders and Silesians as the leading group embodying the "ideology of pioneers" (Kwaśniewski 1968: 168-169). Actually, the higher level of economic and cultural capital among the Silesian population was noticed and appreciated (e.g. Madajczyk and Berlińska 2008: 568; Rauziński 1986: 17), but this potential was not utilized optimally for development purposes. Moreover, in consequence of the successive waves of Silesians' migration to the Federal Republic of Germany in the 1970s and the 1990s, this group, as well as the whole community of Opole Silesia, continued to disintegrate (Jacher 1991).

According to Maria Śmiełowska (1991), the character of contacts among the ethnic groups in Opole Silesia after the war was conflictual. This resulted from the opposing or incompatible standards and values of the cultures of the respective groups; contradictory group interests; civilizational barriers; the transfer of Poles' negative emotional attitude toward Germans and German culture 
to Silesians; and Silesians' negative attitude towards strangers (Śmiełowska 1991: 57). The author is of the opinion that self-adopted stereotypes and externally ascribed stereotypes that developed in that period were also important for the character of inter-group relations in the 1990s. Meanwhile, Danuta Berlińska emphasizes the evolution of inter-group relations from strong antagonism in the first years after the war through hidden conflicts and isolationism to the stage of functional integration in the 1990s (Berlińska 1998: 17). Thus, the aforementioned research indicates that with respect to the post-war period, it is difficult to refer to a regional community characterized by what Robert Putnam referred to as "bridging social capital" - Opole Silesia was divided among groups holding bonding social capital. Additionally, in confrontation with the hostile apparatus of the communist state, the native Silesian population showed alienation and distrust of the official state institutions (Jacher 1994). Nevertheless, it should be reiterated that with the passage of time, all parties managed to work out the methods of cooperation and the institutionalization of inter-group conflicts.

Research focused on the present situation, i.e. the period after 1989, includes various, sometimes opposing, concepts. Below we present a review of the most important conclusions from this research, highlighting relations between multiculturalism and phenomena corresponding to the quality of governance.

According to Robert Rauziński (2007), there is a relationship between the level of education and the share of the non-Polish population in the communes of the Opolskie province: the higher the level of ethnic diversity, the smaller the number of people with secondary and higher education. These differences in education are caused by the migration of persons holding two citizenships to work in Germany. As Romuald Jończy and Diana Rokita-Poskart stated (2013a), a high percentage of the population migrating abroad (especially to Germany) in search of employment, which is characteristic of the multicultural communes in the Opolskie province, causes lower income tax inflows and, consequently, a worse financial position of the local governments. On the contrary, according to the research conducted by Romuald Jończy and Katarzyna ŁukaniszynDomaniewska (2014), the high percentage of the population emigrating abroad had a positive impact on the economic situation of the inhabitants of the region because of the transfer of funds and the stimulation of demand for local goods and services, particularly in the sub-region of Opole (but the authors indicate also the negative fiscal effects of migration, with respect to both income tax and VAT). This impact was visible especially in the 1990s, during the period of the transformational shock, which was being neutralized in the region by means of earnings coming from definitive or circular migration. The researchers also draw attention to the negative influence of emigration on local social capital - it 
caused, among other things, the weakening of local ties and initiatives, the dismantling of the institutional and transport infrastructure (e.g. the liquidation of crèches, kindergartens, schools, and public transport connections).

According to Maria Szmeja, in Opole Silesia, the Silesian population is dominated politically and culturally by the Polish population, which results first of all in Silesians' distancing themselves from the Polish majority. Thus, the region's multiculturalism is not perceived by this author as an added value and an element strengthening the quality of social life (Szmeja 2000; 2017). Marek Mazurkiewicz noticed also $(2015 ; 2017 \mathrm{a})$, that the communes of the Opolskie province inhabited by the German minority are characterized by a lower level of social capital. Meanwhile, the results of the research conducted by Wojciech Opioła (2019) indicate that it is not possible to ascertain definitively that the level of the communes' ethnic diversity influences the level of their inhabitants' social capital and that, in some respects, the latter is higher in the multicultural communes.

According to Brygida Solga, the migrations of the province's inhabitants abroad - the region's distinctive feature against the background of the other parts of Poland - caused the development of a strong network of migrationrelated connections. The network became large enough to exert impact on local and regional development, resulting in the formation of a "circular society". Such a type of a social structure results in a relatively high level of economic capital, but, unfortunately, also in social disintegration (e.g. broken families; Solga 2002). On the other hand, according to Teresa Sołdra-Gwiżdż (1997), extensive and long-lasting activities undertaken by the region's various institutions (e.g. schools, cultural institutions, local authorities) with the aim of developing a joint regional identity in the Opolskie province (by way of autochthonizing the immigrant population and Polonizing the Silesian population) did not result in the development of inhabitants' strong ties with the region.

According to the research conducted by Danuta Berlińska $(1998 ; 1999)$, at the beginning of the 1990s the mobilization and political emancipation of Silesians were defined in terms of belonging to the German national community, and the reconstruction of German national identity in the region was accompanied by antagonisms with the Polish population (e.g. conflicts about monuments). The Silesian population also had lower educational aspirations because the possibility of working in Germany made people give up pursuing further stages of formal education. Thus, connections with the German state and culture weakened social capital throughout the province. But the period of the fight for retaining the separate Opolskie province in 1998 was also a catalyst for province-wide integration crossing the national barriers and the strengthening of inhabitants' identification 
with the region. This process was accompanied by the increasing awareness of the political elites that the region's national diversity required a system aimed at reconciling opposing interests, a dialogue-oriented attitude, and cooperation skills. Furthermore, the results of another study conducted by the author in 1999 indicated that the attitudes of the province's inhabitants to ethnic diversity were evolving towards cooperation across divides and tolerance of cultural differences (Berlińska 2004).

\section{The concept and the main research stages}

In the literature on the subject, the negative influence of ethnic diversity on the quality of governance is emphasized and a new dilemma of liberalism is indicated. There are several theoretical approaches explaining the negative influence of ethnic diversity on the social foundations of democracy. In the light of the psychological theories of prejudices, ethnic divisions lead to inter-ethnic mistrust and intra-ethnic favoritism, and consequently to tensions, conflicts and an absence of readiness to cooperate. The network theory implies that social relations in ethnically divided societies are organized along ethnic lines, which weakens the potential mechanisms of social control and extra-group civic mobilization. Public choice theorists claim that ethnic diversity strengthens the diversity of preferences and aspirations of particular groups, which is the source of antagonisms. Cultural theories point out the absence of a common language and commonly shared meanings as the source of a lack of social coherence understood as a low level of general trust and civic activity. Simultaneously, the theoretical approaches are challenged by the supporters of the psychological contact theory which proves that everyday contacts with representatives of a different culture lead to overcoming prejudices and stereotypes, and consequently to expansion of trust-based ties (Ibidem; Putnam 2007). Avoiding theoretical generalizations and unequivocal conclusions, we can assume the existence of empirical relations between phenomena described by means of such categories as ethnic diversity and the quality of governance. For the purposes of this research project, we define the presented notions as follows:

ethnic diversity (an independent variable) - being aware of the multiplicity of contexts in which the term is used, we understand it as the existence, in the same social space, of two or more social groups with different ethnic or national self-identification and different cultural characteristics. For the purposes of quantitative and qualitative analyses, we will operationalize ethnic diversity by means of two dimensions which will be used to construct a so-called fractionalization index: the number of ethnic groups in a 
community and the proportions of the population of particular groups (cf. Alesina et al. 2003; Putnam 2007).

quality of governance (a dependent variable) is understood in accordance with the concept of so-called good governance, which is a normative point of reference for an assessment of the quality of governance. The quality of governance depends on a degree to which analysed entities meet the criteria of good governance. According to the definition provided by Transparency International, good governance is "participatory, transparent, effective and efficient, responsive, inclusive governance, following the rule of law and assuring that corruption is minimized" (Transparency International 2009).

The two terms and the presented new liberal dilemma and its criticism determine the direction of the research on the Opolskie province communes, and the main hypothesis is actually in provocative contradiction with the dilemma, since according to it, the quality of governance is higher in ethnically diversified communes. An a priori explanation of the adopted hypothesis can be a relatively long history of coexistence of ethnically diversified communities in the region under analysis, which is one of the factors strengthening social capital, and consequently also the local community, a low level of excluding the minority from the distribution of public services, participation of all ethnic groups in governing the commune, etc. (cf. Kumlin and Rothstein 2010; Putnam 2007). It should also be stressed that the aforementioned concept of the new liberal dilemma refers mainly to the discrimination of immigrant minority groups in their access to public goods in new multicultural communities. In the case of the Opolskie province, the situation is different: several years after WWII post-war immigrants (the displaced people and settlers of Polish origin) became the dominant population in Opole Silesia, and the native population underwent political and cultural discrimination (Berlińska 1998; 1999; Lis 1993; Szmeja 2000).

The research was conducted in the Opolskie province in the years 2017-2018. The starting point was to use statistical data from the census to analyze national and ethnic diversity in the Opolskie province communes. The communes were the basic units of analysis. As for the assessment of good governance in the communes, it was based on the operationalization of the rules of good governance selected on the basis of an analysis of international standards (of such organizations as the World Bank, the European Union or the Council of Europe), and the practice of research on the quality of governance in different parts of the world (Wilkin 2008; Wilde et al. 2009; Kemp and Jimenez 2013). The next chapter presents a critical description of the operationalization of ethnic diversity and good governance, and at the end of the book there is an appendix with a detailed list of the adopted good governance indicators. 
The research was conducted on the basis of the nested analysis (Lieberman 2005; Rohlfing 2008), which is one of the conventional methods of comparative studies in political sciences. It allows the combination of a quantitative statistical analysis based on a large number of cases with a qualitative in-depth analysis of several chosen examples. The nested analysis consists in the use of quantitative data in the first stage of the research process in order to make an optimal choice of case studies for a qualitative comparative analysis. The first stage was a quantitative analysis of selected indexes in all communes of the Opolskie province (at this stage, the district towns were finally excluded) in order to measure the quality of governance in these communes. At this stage, the existing data analysis methods and the CAWI (Computer Assisted Web Interview) were applied. One of the differences in the method applied by the authors in comparison with Lieberman's postulate was the replacement of regression analysis with correlation analysis. The existing data used at the stage of measuring the quality of governance refer, depending on the index, to the years 2015-2017, and they come from such sources as the Central Statistical Office, the State Election Commission, the Regional Social Policy Centre, the Public Information Bulletin, and information from the particular communes' websites. To complement the data, on 7 July 2017, an Internet questionnaire was sent to 71 commune and town offices of the province; its specimen is included at the end of the book (more information on the applied CAWI can also be found in the description of the openness indexes). It was used mainly to assess these aspects of the quality of governance which could not be assessed by the authors on the basis of the existing data. We eventually received replies from 66 communes, and data concerning the remaining five communes were obtained during in-depth internet explorations. As a result of the analysis of the existing data and CAWI, information necessary for the assessment of all communes of the Opolskie province was obtained based on 25 indexes of the quality of governance which were assigned to the five rules of good governance: participation, equality, effectiveness, accountability, and openness.

The next research stage was of a qualitative character and consisted in conducting case studies of four communes.

The selected communes were singled out on the basis of the criteria of ethnic diversity and the quality of governance. These are the following four cases:

- an ethnically diversified commune with a low level of the quality of governance,

- an ethnically diversified commune with a high level of the quality of governance, 
- an ethnically homogeneous commune with a low level of the quality of governance,

- an ethnically homogeneous commune with a high level of the quality of governance.

Thus four considerably different units were selected for the qualitative analysis and the keys for the selection were four extreme relations between the dependent and the independent variable distinguished at the stage of the statistical analysis. Simultaneously, because the quantitative analysis did not provide an unequivocal confirmation of the assumed hypotheses, we did not decide to make a random selection of the cases for further analysis (cf. Lieberman 2005: 437). Instead, we applied the diverse case analysis method which provides better results in such situations (Seawright and Gerring 2008).

A case study is a qualitative comparative analysis in which we want to take into consideration a long term perspective (e.g. local social and political history). In the four selected communes an individual in-depth interviews with local leaders as well as some elements of ethnographic studies are also to be included (more information concerning the methodology of case studies can be found in chapter 5). The term local leaders is to be understood as people involved in public affairs of their communes for many years, representing the social side or commune authorities. The objective of the interviews is to facilitate the local qualitative understanding of potential cause-and-effect relations between ethnic diversity and the quality of governance that are dependent upon specific historical conditions that only interviews could recount instead of mere statistical analyses. 


\section{Ethnic diversity and quality of governance. Conceptualization and measurement at the commune level}

Before we focus on the issue of the conceptualization and operationalization of the notions of "ethnic diversity" and "quality of governance", it is necessary to present a general description of the specific character of the administrative level that is being surveyed and compared. This is because the legal and political status of the Polish commune and its social and demographic specificity can have an effect on the directions and possibilities of the quality of governance in the commune. Consequently, these characteristic features should be taken into consideration in the interpretation of research results.

\section{Commune in the Polish political system}

Since 1999 Poland has had a three-level territorial division system within which two local government segments have been shaped: the local system covering communes and districts and the regional system based on provinces. These changes of 1999 have occurred as a part of democratization process of post-Soviet Poland (which had started already in 1989), with the objectives, like: strengthening of local self-government, decentralization and deconcentration of political power (Yoder 2003).

Relations among these three segments of regional and local government are based on a combination of partnership in most cases, however antagonisms over conflicting jurisdictions happen as well. It should be noted that at present the district is regarded as the weakest local government link with a weak financial base, while the commune constitutes the center of local power (Wojciechowski et al. 2014: 19-20). According to the typology of local government systems in Eastern Europe proposed by Paweł Swianiewicz, the Polish system, together with those of Slovakia and Hungary, was classified as "champions of decentralization«. It means that local government assumes responsibility for a wide range of tasks; is characterized by a directly elected mayor (in Poland since 2002, earlier major was elected by a commune council) and a majority voting system for decision making bodies (in communes with up to 20,000 inhabitants). Additionally, local government is characterized by a considerable scope of financial autonomy, which manifests itself in the right to determine the level of local taxes, the transparent criteria for receiving transfers from the central budget, and the right to incur 
debt and credit without external approval of other jurisdictional levels. Among the five types of local government in Eastern Europe proposed by Swianiewicz ${ }^{5}$, the Polish system represents the highest level of decentralization, showing similarities to the so-called Northern model characteristic of the Western European democracies (Swianiewicz 2014: 303-307). Thus, a Polish commune can be justifiably regarded as an autonomous political space since, by way of cyclical and democratic elections, voters appoint decision making authorities and executive authorities are responsible for fulfilling the needs of their self-governing community. Communes also pursue autonomous financial policies and make use of symbols expressing the identity of a local community (an emblem, local feasts, monuments of nature).

Nevertheless, the specific character of this local political system comprises rules of electing authorities, making decisions, and enforcing political responsibility that are determined at the center rather than local level. It means that in communes there exist structural barriers to the possibility of shaping the principles of good governance (Antoszewski 2014: 21-22).

The position of a commune in Poland's political system is defined in Chapter VII of the Constitution of Poland, which guarantees its political and financial autonomy. A commune constitutes a basic local government unit, has the status of a legal person, and its autonomy is protected by courts. It executes all tasks of local government which are not reserved for the competence of the other local government units, i.e. districts and provinces. Its funds comprise its own revenues as well as grants and subsidies from the central budget. A commune's activities are subject to supervision with respect to legality by central government bodies. Such supervision is exercised by the President of the Council of Ministers and provincial governors, while financial matters are monitored by regional accounting chambers ('Constitution' 1997). The range of public tasks carried out by a commune and the principles of the functioning of commune authorities are determined in the Commune Government Act of 8 March 1990. The Act sets forth 20 tasks for which a commune is responsible, among which are real property management, environmental protection, water supply and sewage disposal, municipal waste management, local roads maintenance, social assistance, public education, health care, cultural development, promotional activities, cooperation with and support for local government organizations. A commune's basic

5 Besides "champions of decentralization", the other four types are considered: relatively decentralized, Balkan, high territorial consolidation, and territorial fragmentation with a high level of centralization (Swianiewicz 2014: 303-306). 
governing bodies are a commune council and a commune leader (a mayor or a president, depending on a commune's size). A commune council is a decision making and controlling body. Since 2018 councils have been elected for a five years' term of office (previously for a four years' term of office). The number of councillors in a commune depends on the number of its inhabitants, with the minimum number of 15 councillors in communes with up to 20,000 inhabitants. Since 2018 also elected for a five years' term of office, commune leaders (mayors or presidents) constitute executive bodies of communes. With respect to the performance of public tasks, they are controlled by commune councils. The commune leader implements resolutions passed by the commune council, manages the commune's affairs on an ongoing basis, and represents the commune externally. The commune leader performs their tasks through the commune office and is simultaneously the head of this office.

The above description is just a general and simplified outline of the position, structure, and competences of commune authorities. An analysis of governance at the commune level should also take into consideration the sociological and demographic specificity of communes in Poland, in particular the fact of their considerable diversity. Polish communes are divided into rural, urban-rural, and urban. According to the data for 2016, there were 2478 communes, including 1559 rural ones, 616 urban-rural ones, and 303 urban ones. The average number of inhabitants in one commune was 15,500 (Kaczmarek 2016: 72-74). In comparison to the average size of communes in the other EU Member States, which was 5,600 people in 2010, communes in Poland are medium-sized units (Kachniarz, Babczuk 2014: 2). It should be noted, however, that a considerable number of them are small rural communes with fewer than 5,000 inhabitants. Because of demographic processes, the number of such communes is increasing: in 1992 there were 540 communes with up to 5,000 inhabitants, while in 2013 their number already rose to 618 (Swianiewicz 2014a: 10). It has been argued that the local government reform, particularly the commune government reform of 1990, is one of the most successful aspects of the Polish transformation. Public opinion surveys indicate that local government authorities continuously enjoy a high level of trust exceeding $50 \%$, which is much higher than the result achieved by the central government (Trutkowski 2016: 13-18; Swianiewicz 2017: 1).

Before 1998 local government elections had been regarded as much less important as parliamentary or presidential elections. However, what has been observed since 2008 is a continual growth in the assessments of the importance of local government (and all other) elections, with local government elections regarded as more significant that parliamentary or presidential ones since 2012 (Gendźwiłł, Żerkowska-Balas 2018: 5). Nevertheless, the local government 


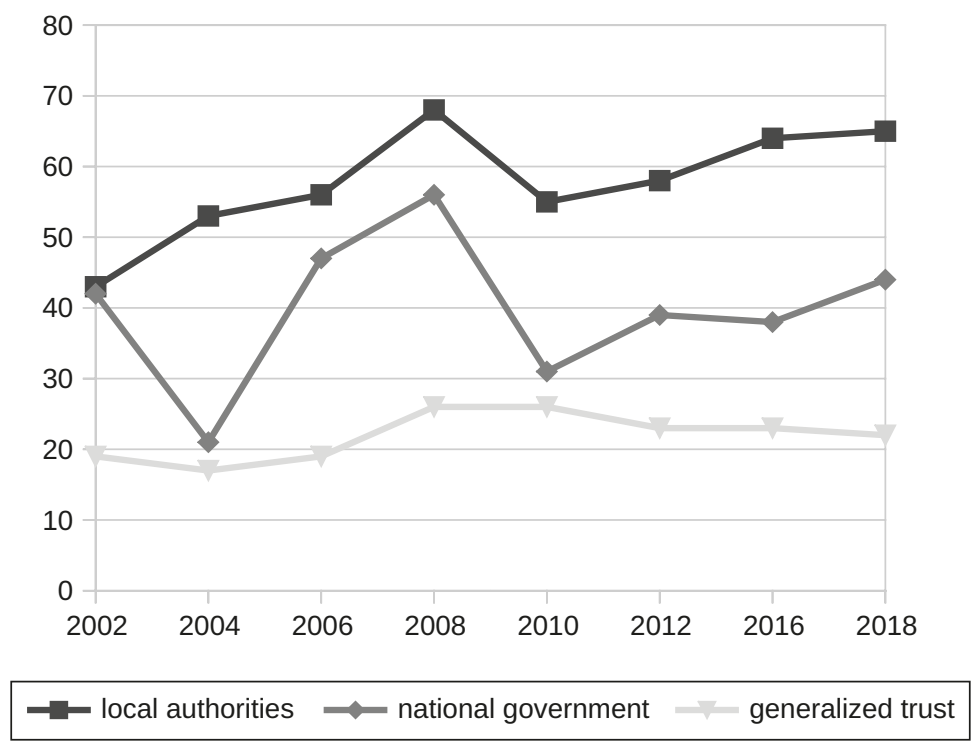

Fig. 1: Level of trust towards local authorities, national government and generalized trust in Poland 2002-2018. Source: Public Opinion Research Center (CBOS)

election turnout in the years 2006-2014 was a little bit lower than in the parliamentary elections held in that period, which was the effect of a relatively low turnout in large cities. There is a clear correlation between the size of a commune and an election turnout: the smaller the commune, the higher the turnout in local government elections (Flis 2018: 3).

Local government elections, in which voters elect their representatives to commune, district and provincial authorities, are dominated by choices made at the level of individual communes. According to the data for 2014, $78 \%$ of Poles were of the opinion that the election of commune authorities was the most important decision made during local government elections (Gendźwiłł, Żerkowska-Balas 2018: 9). Local government at the commune level is the closest to Poles, but high opinions of its importance result also from the scope of its competencies and the amount of public funds remaining at its disposal. In 2016 the expenditures of commune governments constituted $85 \%$ of all local government expenditures. The research conducted in 2018 shows that $60 \%$ of Poles are of the opinion that they influence matters in their own communes, while only $40 \%$ believe that they have any impact on matters at the national level (Gendźwiłł, Żerkowska-Balas 


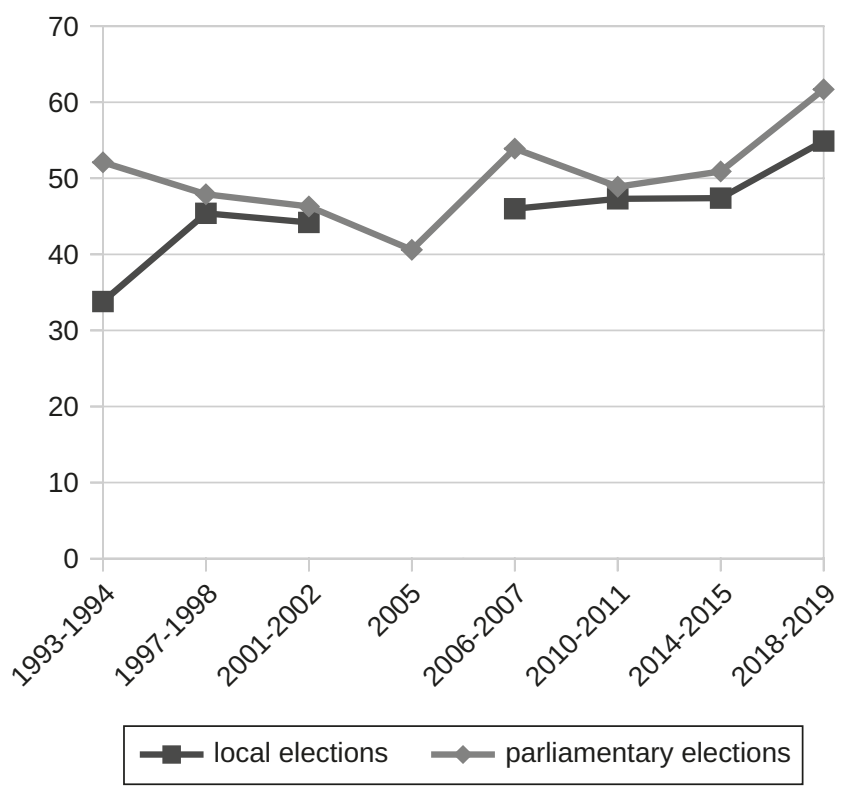

Fig. 2: Election turnout to the local and parliamentary elections in Poland 1993-2019*. Source: National Electoral Commission of Poland (PKW).

*In 2005 there were only parliamentary elections

2018: 9). As it has been noted above, the size of a commune is also of some significance. Small Polish communes are characterized by more interest in local politics, better knowledge of the functioning of local government authorities, and a higher level of trust in such authorities (Swianiewicz 2010: 12-16). Politics at the commune level is also characterized by low party dependency, with the lowest dependency in the smallest communes. The data for local government elections in the years 2006 and 2010 indicate that the highest level of independence of party affiliation occurred in communes with from 10,000 to 20,000 inhabitants (communes with fewer than 10,000 inhabitants were in the second place). In such communes, candidates put forward by non-party committees won $81.5 \%$ (2006) and $80 \%$ (2010) votes, respectively. As far as commune leaders and mayors characterized by the so-called double non-partyism (i.e. those not being members of any party and simultaneously elected from non-party committees) are concerned, they constituted $73 \%$ (2006) and $71 \%$ (2010) of representatives elected in such communes (Gendźwiłł, Żółtak 2012: 108-109). 
Finishing this description of the Polish local government at the commune level, we should mention the main problems it has been coping with since its establishment 25 years ago. They include excessive encumbrances resulting from the execution of public tasks in the conditions of the lack of funds necessary for it, as the subsequent extensions of the list of public tasks have not been accompanied by the strengthening of communes' financial positions. Commune authorities are also burdened by the central government with delegated tasks without being provided with sufficient funds or sovereign competencies, which reduces local government units to the role of the passive executors of the central government's policies. Another issue is defective laws passed at the central government level which fail to take into consideration local conditions and excessive regulatory burden preventing local governments from making and implementing decisions effectively. There is also a visible lack of consistency in the national development policy, for example in the area of regional development strategies or the central government's readiness for trust-based cooperation with local government associations. The weaknesses of the strategic approach concern also commune authorities as many communes have failed to adopt a local development strategy and many of the adopted strategies do not result from dialogues and cooperation with local communities. There are also many doubts concerning the structure of the local government system. For example, its division into very many small units raises questions about the possibility of the effective and efficient provision of public services. The existence of three government levels whose tasks sometimes tend to overlap results in conflicts about the ranges of competencies, for example with respect to road maintenance. There is also a lack of cooperation among communes which if solved could lead to the strengthening of their potential. There occur also problems with the implementation of particular public policies, in particular those related to education and regional planning for which local governments are responsible, although their competencies in these areas are restricted by the central government administration and the national legislation. Some local governments are also fraught with internal conflicts between the council and the executive body or within the council itself. Such conflicts may lead to deliberation and greater representative policy or compromises yet as well may hinder effective governance and exert a negative impact on the perception of local government activities by local communities. The additional problems that communes have to deal with are a weakness of the local civil society and many people's ignorance of the role of democratic participatory procedures introduced on matters important for the local community (Trutkowski 2016: 19-39). 


\section{Ethnic diversity}

In our research, ethnic diversity is an independent variable. Although in many researches this category is regarded as a primary concept, it seems justifiable to ask how ethnic diversity should be defined, especially at the operational level, and what its effects are in different situations. We start with the assumption that ethnic diversity is difficult to perceive as a state instead of as a moving target due to, among other things, the dynamics of migration, changes in legal regulations, or changes of ethnic and cultural self-identifications. Therefore, it is necessary to pose questions concerning both the manner of measuring diversity and the method of identifying "fractions" within an internally diversified community. Additional difficulties are caused by the fact that the category of ethnicity does not have one generally accepted scientific definition.

Ethnic diversity is understood as "the acknowledged co-occurrence, in the same space (or in the immediate proximity without a clear delimitation, or in the situation of aspiring to occupy the same space), of two or more social groups with relatively different cultural features" (Golka 2010: 64-65). The fragment quoted above is a part of the definition of multiculturalism put forward by Marian Golka. The very category of multiculturalism in the Polish scientific discourse is exceptionally broad-ranging and functions in social sciences with at least the following four meanings: (1) a factual state of ethnic diversity in a given space $^{6},(2)$ a policy aimed at the institutionalization of ethnic diversity, (3) a political program promoting multiculturalism as a desired feature of modern democratic societies, (4) a marketing strategy referring to the promotion of the folklore of minorities as a value increasing the tourist attractiveness of ethnically diversified areas (cf. Dolińska 2016).

In this research, the authors are interested in not only the fact of the occurrence of ethnically diversified local communities but also measurement of the degree of such diversity. Consequently, analyzing the communities inhabiting the Opolskie province, we should pose and answer the following questions:

- How many culturally/ethnically diversified groups should be distinguished?

- What data should constitute a basis for recognizing a given person as a member of an ethnic group?

- What data should constitute a basis for calculating the ratios of the members of every group?

6 This meaning of multiculturalism as a factual state of ethnic diversity is the closest to our definition of ethnic diversity. 
- How should dynamic changes taking place in the ethnic groups be taken into consideration?

- Should the cultural distance among the ethnic groups be taken into consideration? If so, in what way?

These questions result from adopting the diversity measurement method used generally in sciences and they also refer to the debate on methodological dilemmas related to various methods of measurement. An examination of ethnic and ethnolinguistic fractionalization is the most commonly used method of measuring ethnic diversity (Alesina et al. 2003, Fearon 2003, Posner 2004). This method takes into consideration the number of ethnic groups and, to some extent, the ratios among the numbers of the members of every group in the population, but it disregards the cultural distance (or differences in income) separating particular groups and the consequent possibility of social polarization. The polarization index (Chakravarty and Maharaj 2011; Esteban and Ray 1994; Montalvo and Reynal-Querol 2002; 2005) is an attempt to address this issue. It was developed mainly as a means of measuring the probability of the occurrence of conflicts and civil wars in ethnically diversified societies. Thus, for our purposes, we have adopted the ethnic fractionalization index as a basis for the assessment of ethnic diversity. This measurement method is explained in more detail in the further part of the chapter.

\section{The number of groups}

The research conducted on the population of the inhabitants of the Opolskie province is characterized by a relatively high degree of diversification with respect to the number of culturally different groups identified for the research purposes. Both the number and character of these groups were changing in parallel to changes in the dynamics of relocation processes, migration, demographic changes, as well as changes in self-identification. Before World War II the basic criterion of dividing the population was language: people spoke either Polish or German. After the war, four groups were usually distinguished: the so-called Polish native population, Germans, people displaced from the territories of the Soviet Union (the former territories of the second Republic of Poland), and settlers from Poland (see Map 3 in chapter 3). After 1989, in consequence of the "emergence" and institutionalization of the German minority, the population was divided culturally and ethnically into Poles and Germans, and in the subsequent years into Poles, Germans, and Silesians (cf. e.g. Berlińska 1999; Kowalski 1972; Kwiatek 2018; Rauziński 1982; 1986; 1998; Szmeja 1997; 2000). The detailed information on this division is presented in Tab. 1. 
Tab. 1: The cultural and ethnic diversity of the Opolskie province ${ }^{7}$ in the years 19481993: the number of inhabitants, nomenclature, data sources

\begin{tabular}{|c|c|c|c|c|c|c|}
\hline Year & $\begin{array}{l}\text { Population } \\
\text { identified with } \\
\text { Polishness }\end{array}$ & $\begin{array}{l}\text { Population } \\
\text { identified } \\
\text { with } \\
\text { Germanness }\end{array}$ & $\begin{array}{l}\text { Population } \\
\text { identified } \\
\text { with } \\
\text { nativeness/ } \\
\text { Silesianness } \\
\end{array}$ & Others & Source & $\begin{array}{l}\text { Data } \\
\text { acquisition } \\
\text { method }\end{array}$ \\
\hline 1948 & $\begin{array}{l}\text { Displaced persons - } \\
\text { approx. } 144,000 ; \\
\text { Repatriates - } \\
\text { approx. } 169,000\end{array}$ & $\begin{array}{l}\text { Germans - } \\
\text { approx. } 2000\end{array}$ & $\begin{array}{l}\text { Native } \\
\text { inhabitants - } \\
\text { approx. } \\
440,000\end{array}$ & $\begin{array}{l}\text { Reemigrants - } \\
\text { appox. 27,000 } \\
\text { Others - } \\
<1000\end{array}$ & $\begin{array}{l}\text { Rauziński } \\
1998\end{array}$ & no data \\
\hline 1948 & $\begin{array}{l}\text { Polish native } \\
\text { population - } \\
\text { 420,800; } \\
\text { Repatriates - } \\
\text { 179,900; Displaced } \\
\text { persons - } 161,100\end{array}$ & - & - & $\begin{array}{l}\text { Reemigrants - } \\
29,800\end{array}$ & $\begin{array}{l}\text { Kowalski } \\
1972\end{array}$ & $\begin{array}{l}\text { Situational } \\
\text { reports of } \\
\text { district offices; } \\
\text { delivery and } \\
\text { acceptance } \\
\text { reports; the } \\
\text { population } \\
\text { census in the } \\
\text { Regained } \\
\text { Territories of } \\
\text { 31 December } \\
1948\end{array}$ \\
\hline 1950 & $\begin{array}{l}\text { Displaced } \\
\text { persons from the } \\
\text { East - 188,300 } \\
\text { Settlers from within } \\
\text { Poland - 158,100 }\end{array}$ & - & $\begin{array}{l}\text { Silesians - } \\
436,000\end{array}$ & - & Szmeja 1997 & $\begin{array}{l}\text { The national } \\
\text { census of } 1950\end{array}$ \\
\hline 1950 & $\begin{array}{l}\text { Incoming } \\
\text { population from } \\
\text { Poland (settlers) } \\
-211,000 \\
\text { Incoming } \\
\text { population } \\
\text { from abroad } \\
\text { (repatriates) - } \\
180,200\end{array}$ & - & $\begin{array}{l}\text { Native } \\
\text { (indigenous) } \\
\text { population - } \\
418,300\end{array}$ & - & $\begin{array}{l}\text { Rauziński } \\
1986\end{array}$ & no data \\
\hline
\end{tabular}

(continued on next page)

7 Although the Opolskie province has been a unit of the administrative division of Poland since 1950, its boundaries were changed in every territorial organization reform. In the years 1950-1975 it included the Raciborski and Oleski districts; in the years 1975-1998 these two districts belonged to other provinces, while the 1998 reform returned the Oleski district and the communes of Praszka and Rudniki to the Opolskie province. Besides, some data sources refer to still other territorial units. The research conducted by Danuta Berlińska (1999) in 1990 covered the area of the historical region of Opole comprising also the cities of Zabrze, Bytom, and Gliwice. 
Tab. 1: Continued

\begin{tabular}{|c|c|c|c|c|c|c|}
\hline Year & $\begin{array}{l}\text { Population } \\
\text { identified with } \\
\text { Polishness }\end{array}$ & $\begin{array}{l}\text { Population } \\
\text { identified } \\
\text { with } \\
\text { Germanness }\end{array}$ & $\begin{array}{l}\text { Population } \\
\text { identified } \\
\text { with } \\
\text { nativeness/ } \\
\text { Silesianness }\end{array}$ & Others & Source & $\begin{array}{l}\text { Data } \\
\text { acquisition } \\
\text { method }\end{array}$ \\
\hline 1977 & $\begin{array}{l}\text { Incoming } \\
\text { population - } \\
601,800\end{array}$ & - & $\begin{array}{l}\text { Population of } \\
\text { local origin } \\
-371,200\end{array}$ & - & $\begin{array}{l}\text { Rauziński } \\
\text { 1982; the } \\
\text { authors' } \\
\text { own } \\
\text { calculations }\end{array}$ & $\begin{array}{l}\text { The authors' } \\
\text { own } \\
\text { calculations, } \\
\text { a study by } \\
\text { J. Balaryn; } \\
\text { a cumulative } \\
\text { dataset on } \\
\text { emigration }\end{array}$ \\
\hline 1990 & Poles - $58 \%$; & $\begin{array}{l}\text { Germans - } \\
7.2 \%\end{array}$ & $\begin{array}{l}\text { Silesians - } \\
34.8 \% \text {; }\end{array}$ & - & $\begin{array}{l}\text { Berlińska } \\
1999\end{array}$ & $\begin{array}{l}\text { Questionnaire } \\
\text { survey } \\
(\mathrm{N}=486)\end{array}$ \\
\hline 1993 & Poles - $66.9 \%$; & $\begin{array}{l}\text { Germans - } \\
5.2 \% \text {; }\end{array}$ & $\begin{array}{l}\text { Silesians - } \\
27.5 \% \text {; }\end{array}$ & - & $\begin{array}{l}\text { Berlińska } \\
1999\end{array}$ & $\begin{array}{l}\text { Questionnaire } \\
\text { survey } \\
(\mathrm{N}=496)\end{array}$ \\
\hline
\end{tabular}

Source: the authors' own work based on scientific literature.

For the research purposes, we decided to distinguish the following three groups: Poles, Germans, and Silesians. This choice reflects the best the current demographic position of the province and the numerical strength of these groups is the easiest to establish ${ }^{8}$.

\section{A group differentiation basis}

Either objective or subjective data may be used as a basis for differentiating ethnic, cultural or national groups. The former data include the legal status, i.e. citizenship, recognition as a member of a minority ethnic or national group, or the language used by a given person at home. The latter data comprise ethnic or national self-identification expressed in a census. In the case under analysis, we decided to rely on subjective data. There were a few reasons for this decision. First of all, the decisive majority of the inhabitants of the Opolskie province are Polish

8 The latest statistics indicate also a large number of Ukrainians (more than 60,000 persons, according to the data of the Provincial Labour Office). However, Ukrainian citizens (mainly construction or industrial workers and students) live first of all in district towns, which are not the subject matter of our research. 
citizens; there is also a certain group of people with two citizenships, Polish and German. This fact ruled out using citizenship as a measure of group differentiation. Secondly, we aimed to distinguish three groups: Poles, Germans, and Silesians. It should be noted that, in the light of Polish regulations concerning national minorities and regional languages, Silesians are not recognized as a separate group. Therefore, there was no possibility of using data concerning officially recognized ethnic, national, and regional minorities. It turned out that the most adequate measure was the subjective national self-identification expressed in a census. Determining the degree of ethnic diversity, we first took into consideration the censuses carried out in 2002 and 2011. However, during the preliminary data analysis it turned out that in 2011 not all census participants had been asked openly and directly about their nationality. Therefore, the data from the 2011 census are to some extent of an approximate character (cf. Barwiński 2014). Consequently, it was the data collected in the 2002 census that constituted the basic source of information on minorities.

\section{Group size ratios}

The distribution of the sizes of the groups in the population is a significant measure of the degree of ethnic diversity. According to the adopted EFI index, a commune inhabited by three separate groups with each of them comprising $1 / 3$ of the total members of the population is more ethnically diversified than a commune inhabited by ten groups with one dominant majority group ( $90 \%$ of the population) and the remaining nine ethnic groups comprising $10 \%$ of the members of the population. This is a hypothetical example which did not occur in the communes under examination. Nevertheless, the information on the numbers of the members of the particular groups was important in the light of the province's demography. The province includes communes where Poles constitute the majority of inhabitants (over $95 \%$ ) and the minority is a socially and culturally insignificant group, as well as communes with less than $50 \%$ of Polish inhabitants. At the same time, all studied communes were inhabited by the same ethnic groups: Poles, Germans, and Silesians (some larger towns are inhabited by the Romany minority; however, most of them are district towns, which were not included in the research, and the number of Romany people is statistically irrelevant). The measurement of the ratios and the interest in including Silesians in the research as a separate important group was an additional factor determining the adoption of census-based self-identification as a measure of the groups' size.

For verification purposes, we examined the correlation between ethnolinguistic diversity and ethnic diversity (on the basis of the 2002 census data) in 
people declaring German nationality and people declaring the use of the German language in the household environment. At 0.98 , this is a very strong correlation. Unfortunately, because of the lack of data at the commune level on the number of people using the Silesian language at home, a comparable analysis could not be carried out for the Silesian minority. The lack of such data was also one of the reasons for not using ethnolinguistic diversity as a measure.

\section{Dynamics of changes}

Ethnic diversity is subject to change over time. This is influenced by such factors as migration, reproductiveness and mortality (as well as reproduction strategies, which may be specific with respect to ethnic affiliation), and also the process of developing collective identities. As our research was an analysis of the situation at a particular point in time (most of the research was conducted in 2018 and was based on the data for the period 2015-2017), we were able to disregard the impact of changes in the social, demographic, and cultural spheres.

Nevertheless, the dynamics of changes in the ethnic structure was important for us in one aspect, namely the temporal distance between the data on ethnic diversity used in the research (the year 2002) and the time of conducting the research. The distance of 15 years is a period that needs to be taken into consideration, at least in order to make stipulations which may to some degree influence the explanation of data obtained at the further stages of the research. We identified three processes that had been taking place in the recent years and had had the potential to influence the ethnic structure of the communes in the Opolskie province:

- Poland's accession to the European Union and consequently the Schengen area, which had a considerable impact on the character of economic migration in the region. Before 2004 it had been Germans and Silesians who had acquired German citizenship (it had been possible since 1993) that were able to move freely and look for employment in the countries of the European Union. Therefore, there had been clear differences between Silesians and Germans on the one side and Poles on the other side with respect to employment in Poland and abroad. What was observed after 2004 was both an increase in the number of people of Polish nationality taking up employment

abroad and a decrease in the number of people with two citizenships working outside Poland. More and more people with two citizenships managed to find jobs in their home country (Jończy, Rokita-Poskart 2013b; 2014).

- a decrease in the number of people of German nationality resulting first of all from the more regressive age pyramid in that ethnic group. This observation 
was based on a comparison of self-identification declarations made in the censuses in 2002 and 2011 as well as changes in the number of members of the Social and Cultural Association of Germans in Opole Silesia. According to the census, in the year 2002 104,399 people living in the Opolskie province declared to be of German nationality, while in the year 2011 this number fell to $78,595^{9}$. In the case of the Social and Cultural Association of Germans, the number of its members decreased from 36,170 in 2013 to 29,464 in $2017^{10}$.

- an increase in the number of people of Silesian nationality resulting from the formation of a new identity. The first decade of the 21 st century witnessed a dynamic increase in the separate regional (or national) awareness of Silesians, which was reflected, among other things, in the conducted censuses. While in 2002 Silesian nationality was declared by 24,000 inhabitants of the Opolskie province, in 2011 this number rose to $105,000^{11}$.

\section{Cultural distance}

The last aspect of ethnic diversity that needs to be taken into consideration is cultural distance. Cultural distance refers to differences in values, behaviors, and systems of symbols which can be analyzed in a few dimensions. The most complete analysis of the dimensions of national cultures was carried out by Geert Hofstede within the scope of a couple of research projects executed since the 1960s (Hofstede, Hofstede, Minkov 2011). Hofstede (in the subsequent years together with associates) distinguished six dimensions of cultural differences (power distance, individualism, masculinity, uncertainty avoidance, long term orientation, indulgence) and, equally importantly, quantified a value of each of the dimensions for a few dozen national cultures. The academic community is continuing the discussion whether ethnic diversity is the most adequate indicator (independent variable) in comparative studies. Some researchers, e.g. James Fearon (2003), Jose Montalvo and Marta Reynal-Querol (2002; 2005) are of the opinion that differences, for example, in the quality of life, well-being, or

9 http://stat.gov.pl/spisy-powszechne/narodowe-spisy-powszechne/narodowy-spispowszechny-2002/ i http://stat.gov.pl/spisy-powszechne/nsp-2011/nsp-2011-wyniki/ struktura-narodowo-etniczna-jezykowa-i-wyznaniowa-ludnosci-polskinsp-2011,22,1.html (Accessed 21 February 2019).

10 http://skgd.pl/sprawozdania/\#2017 (Accessed 21 February 2019).

11 It should be noted that such a big difference results partly also from the different method of obtaining data on nationality and the differently formulated questions and proposed answers (cf. Barwiński 2014). 
the level of democracy are explained better by ethnic polarization than by diversity itself. In other words, what is of key importance is polarization among separate groups inhabiting the same area rather than the number of minorities and their status. This issue is elaborated in more detail in chapter one.

In our research, we distinguish the following three groups: Poles, Germans, and Silesians. Simultaneously since there are no communities participating in the research where it would be possible to distinguish another fourth group numerous enough to influence the research results. Since all three groups are present in each of the examined communes and since the communes have different group size ratios, we decided to disregard cultural distance because, concerning the same groups, it is the same in each commune.

The other doubts deserving consideration are the following: To what extent are Silesians culturally different from Germans? Taking into consideration the history of immigration to Silesia, should the group of Poles be regarded as culturally homogeneous? As far as the first doubt is concerned, we did not ascertain any significant correlations between the Silesian and German populations. What is more, during the 2011 census it was observed that in the case of declaring a double national identity, the number of people declaring the possession of the joint Silesian and Polish identity was over ten times larger than those declaring the joint Silesian and German identity ${ }^{12}$. Simultaneously, the clear and mass motivation to express self-identification with Silesian nationality does not allow the researcher to regard the Silesian population as culturally identical with the Polish population. As far as the other doubt is concerned, it was concluded that the period of 70 years since the largest movements of people in Opole Silesia resulted in a situation where the differences between people displaced from the East and settlers from central Poland were no longer of any great importance.

\section{Method of measurement}

Taking into consideration the aforementioned reservations, we adopted the ethnic fractionalization index as an ethnic diversity index (EFI; Alesina et al. 2003). The ethnic fractionalization index is a measure of both the number of ethnic groups and the ratios of their sizes. It is calculated according to the following formula:

$$
E F I=1-\left(a^{2}+b^{2}+c^{2} \ldots+n^{2}\right)
$$

12 http://stat.gov.pl/spisy-powszechne/nsp-2011/nsp-2011-wyniki/struktura-narodowoetniczna-jezykowa-i-wyznaniowa-ludnosci-polski-nsp-2011,22,1.html (Accessed 4 March 2019). 
where $a, b, c \ldots n$, is the percentage share of each ethnic group in the population of every commune (expressed as a fraction of unity). For example, in the commune $\mathrm{X}$ where the population of group a would be $45 \%$, the population of group $\mathrm{b}-35 \%$, and the population of group $\mathrm{c}-20 \%$, the ethnic fractionalization index would be calculated as follows:

$$
\begin{aligned}
E F I_{x} & =1-\left(0.45^{2}+0.35^{2}+0.2^{2}\right)=1-(0.2025+0.1225+0.04) \\
& =1-0.365=0.635
\end{aligned}
$$

The ethnic fractionalization index can range in value from 0 to 1 , where 0 signifies an ethnically homogeneous population (all members of the population belong to one ethnic group), and 1 stands for a perfectly diversified population (every member of the population belongs to a different ethnic group).

Tab. 2 presents EFI values for all communes in the Opolskie province. The data constituting the basis for the calculation of the index come first of all from the census carried out in 2002. The number of the members of the Silesian minority was estimated by comparing nationality declarations made in the years 2002 and 2011 at the level of districts.

\section{Quality of governance}

As was noticed in the introduction, we deal with the situation in which the discourse on good governance is dominated by thinking in general state categories, while methodological and axiological considerations call for a greater focus on the local level. Therefore, in this part of the book, the concept of good governance is transferred to the level of the Polish commune, which will be followed by the conceptualization and operationalization of the criteria of good governance used in this study. We will first present a general outline of the basic sources for the concept of good governance, including the most important principles/criteria (we use the notions of the principles or criteria of good governance interchangeably) making it possible to determine when governance is good. We will also distinguish the main directions in the research on good governance at the local level. As it has already been mentioned, good governance is first of all the subject of research focused on the national scale, but it does not mean that it has not been studied at the local level. International experiences in this area were synthesized in "A Practical Guide to Measuring Governance at the Local Level" issued by the Oslo Governance Centre at the United Nations Development Programme. It contains a review of 22 initiatives/tools used to measure the quality of local governance in various parts of the world (Wilde et al. 2009). As far as Polish experiences in researching good governance at the commune level are concerned, one of few examples of a comprehensive application of this concept is 
Tab. 2: Ethnic fractionalization in the communes of the Opolskie province ${ }^{13}$

\begin{tabular}{|c|c|c|c|c|}
\hline $\begin{array}{l}\text { Name of } \\
\text { commune/ } \\
\text { district }\end{array}$ & $\begin{array}{l}\text { Percentage of } \\
\text { Polish population }\end{array}$ & $\begin{array}{l}\text { Percentage of } \\
\text { Silesian population }\end{array}$ & $\begin{array}{l}\text { Percentage of } \\
\text { German population }\end{array}$ & EFI \\
\hline Opole & 0.89 & 0.07 & 0.02 & 0.19 \\
\hline \multicolumn{5}{|c|}{ Brzeski District: } \\
\hline Brzeg & 0.97 & 0.01 & 0.00 & 0.04 \\
\hline Grodków & 0.98 & 0.02 & 0.00 & 0.04 \\
\hline Lewin Brzeski & 0.97 & 0.02 & 0.00 & 0.05 \\
\hline Lubsza & 0.98 & 0.02 & 0.00 & 0.03 \\
\hline Olszanka & 0.99 & 0.01 & 0.00 & 0.03 \\
\hline Skarbimierz & 0.99 & 0.01 & 0.00 & 0.03 \\
\hline \multicolumn{5}{|c|}{ Głubczycki District } \\
\hline Baborów & 0.87 & 0.04 & 0.09 & 0.23 \\
\hline Głubczyce & 0.97 & 0.03 & 0.00 & 0.07 \\
\hline Kietrz & 0.98 & 0.02 & 0.00 & 0.04 \\
\hline Branice & 0.94 & 0.05 & 0.01 & 0.11 \\
\hline \multicolumn{5}{|c|}{ Kędzierzyńsko-Kozielski District } \\
\hline Kędzierzyn-Koźle & 0.87 & 0.08 & 0.04 & 0.23 \\
\hline Bierawa & 0.66 & 0.07 & 0.26 & 0.49 \\
\hline Cisek & 0.42 & 0.15 & 0.43 & 0.62 \\
\hline Pawłowiczki & 0.61 & 0.18 & 0.21 & 0.55 \\
\hline Polska Cerekiew & 0.60 & 0.18 & 0.22 & 0.56 \\
\hline Reńska Wieś & 0.38 & 0.27 & 0.35 & 0.66 \\
\hline \multicolumn{5}{|c|}{ Kluczborski District: } \\
\hline Byczyna & 0.96 & 0.03 & 0.01 & 0.07 \\
\hline Kluczbork & 0.83 & 0.07 & 0.10 & 0.30 \\
\hline Wołczyn & 0.96 & 0.02 & 0.02 & 0.08 \\
\hline Lasowice Wielkie & 0.48 & 0.14 & 0.38 & 0.61 \\
\hline \multicolumn{5}{|c|}{ Krapkowicki District: } \\
\hline Gogolin & 0.58 & 0.24 & 0.17 & 0.57 \\
\hline Krapkowice & 0.74 & 0.11 & 0.15 & 0.42 \\
\hline Zdzieszowice & 0.71 & 0.19 & 0.10 & 0.45 \\
\hline
\end{tabular}

13 The population percentages do not add up to $100 \%$ because some communes are inhabited by representatives of other minorities. Furthermore, in the case of data aggregated at the level of the province, double national identifications were taken into consideration. 
Tab. 2: Continued

\begin{tabular}{|c|c|c|c|c|}
\hline $\begin{array}{l}\text { Name of } \\
\text { commune/ } \\
\text { district }\end{array}$ & $\begin{array}{l}\text { Percentage of } \\
\text { Polish population }\end{array}$ & $\begin{array}{l}\text { Percentage of } \\
\text { Silesian population }\end{array}$ & $\begin{array}{l}\text { Percentage of } \\
\text { German population }\end{array}$ & EFI \\
\hline Strzeleczki & 0.41 & 0.17 & 0.42 & 0.63 \\
\hline Walce & 0.39 & 0.29 & 0.32 & 0.66 \\
\hline \multicolumn{5}{|c|}{ Namysłowski District: } \\
\hline Namysłów & 0.98 & 0.02 & 0.00 & 0.04 \\
\hline Domaszowice & 0.98 & 0.02 & 0.00 & 0.05 \\
\hline Pokój & 0.85 & 0.07 & 0.08 & 0.26 \\
\hline Świerczów & 0.99 & 0.00 & 0.01 & 0.02 \\
\hline Wilków & 0.98 & 0.02 & 0.00 & 0.04 \\
\hline \multicolumn{5}{|c|}{ Nyski District: } \\
\hline Głuchołazy & 0.97 & 0.02 & 0.00 & 0.05 \\
\hline Korfantów & 0.86 & 0.07 & 0.07 & 0.26 \\
\hline Nysa & 0.95 & 0.04 & 0.00 & 0.10 \\
\hline Otmuchów & 0.98 & 0.02 & 0.00 & 0.04 \\
\hline Paczków & 0.98 & 0.02 & 0.00 & 0.04 \\
\hline Kamiennik & 0.97 & 0.03 & 0.00 & 0.06 \\
\hline Łambinowice & 0.91 & 0.07 & 0.01 & 0.16 \\
\hline Pakosławice & 0.99 & 0.01 & 0.00 & 0.02 \\
\hline Skoroszyce & 0.99 & 0.01 & 0.00 & 0.03 \\
\hline \multicolumn{5}{|c|}{ Oleski District: } \\
\hline Dobrodzień & 0.58 & 0.17 & 0.25 & 0.57 \\
\hline Gorzów Śląski & 0.74 & 0.09 & 0.17 & 0.42 \\
\hline Olesno & 0.65 & 0.11 & 0.24 & 0.51 \\
\hline Praszka & 0.99 & 0.01 & 0.00 & 0.02 \\
\hline Radłów & 0.48 & 0.24 & 0.28 & 0.64 \\
\hline Rudniki & 0.99 & 0.01 & 0.00 & 0.01 \\
\hline Zębowice & 0.39 & 0.17 & 0.44 & 0.63 \\
\hline \multicolumn{5}{|c|}{ Opolski District: } \\
\hline Niemodlin & 0.98 & 0.01 & 0.00 & 0.03 \\
\hline Ozimek & 0.70 & 0.11 & 0.19 & 0.46 \\
\hline Prószków & 0.57 & 0.12 & 0.31 & 0.57 \\
\hline Chrząstowice & 0.54 & 0.19 & 0.27 & 0.60 \\
\hline Dąbrowa & 0.72 & 0.11 & 0.17 & 0.44 \\
\hline Dobrzeń Wielki & 0.58 & 0.21 & 0.21 & 0.58 \\
\hline
\end{tabular}


Tab. 2: Continued

\begin{tabular}{lllll}
\hline $\begin{array}{l}\text { Name of } \\
\text { commune/ } \\
\text { district }\end{array}$ & $\begin{array}{l}\text { Percentage of } \\
\text { Polish population }\end{array}$ & $\begin{array}{l}\text { Percentage of } \\
\text { Silesian population }\end{array}$ & $\begin{array}{l}\text { Percentage of } \\
\text { German population }\end{array}$ & EFI \\
\hline Komprachcice & 0.56 & 0.13 & 0.31 & 0.57 \\
Lubniany & 0.45 & 0.27 & 0.28 & 0.65 \\
Murów & 0.61 & 0.07 & 0.32 & 0.52 \\
Popielów & 0.64 & 0.16 & 0.20 & 0.53 \\
Tarnów Opolski & 0.53 & 0.21 & 0.24 & 0.61 \\
Tułowice & 0.96 & 0.03 & 0.01 & 0.08 \\
Turawa & 0.59 & 0.20 & 0.21 & 0.57 \\
& & Prudnicki District: & & \\
Biała & 0.48 & 0.09 & 0.43 & 0.58 \\
Głogówek & 0.69 & 0.06 & 0.25 & 0.46 \\
Prudnik & 0.97 & 0.02 & 0.01 & 0.07 \\
Lubrza & 0.92 & 0.01 & 0.06 & 0.14 \\
& & Strzelecki District: & & \\
Kolonowskie & 0.51 & 0.06 & 0.43 & 0.55 \\
Leśnica & 0.55 & 0.17 & 0.28 & 0.59 \\
Strzelce Opolskie & 0.74 & 0.13 & 0.14 & 0.42 \\
Ujazd & 0.62 & 0.13 & 0.25 & 0.54 \\
Zawadzkie & 0.67 & 0.14 & 0.19 & 0.49 \\
Izbicko & 0.53 & 0.19 & 0.28 & 0.61 \\
Jemielnica & 0.53 & 0.22 & 0.24 & 0.61 \\
Total Opolskie & $\mathbf{0 . 8 8}$ & $\mathbf{0 . 1 3}$ & $\mathbf{0 . 0 8}$ & \\
province: & & & & $\mathbf{0 . 2 0}$ \\
\hline
\end{tabular}

The authors' own work based on: Struktura narodowo-etniczna, językowa i wyznaniowa ludności Polski - NSP 2011 (Accessed 5 March 2019 at: http://stat.gov.pl/spisy-powszechne/nsp-2011/ nsp-2011-wyniki/struktura-narodowo-etniczna-jezykowa-i-wyznaniowa-ludnosci-polskinsp-2011,22,1.html); Wyniki Narodowego Spisu Powszechnego Ludności i Mieszkań 2002 w zakresie deklarowanej narodowości oraz języka używanego w domu (Accessed 5 March 2019 at: http://stat.gov.pl/spisy-powszechne/narodowe-spisy-powszechne/narodowy-spispowszechny-2002/wyniki-narodowego-spisu-powszechnego-2002-narodowosci-oraz-jezyka/); Barwiński 2014.

the project entitled Good Governance in the Micro Scale - an Innovative System for the Analysis of Public Tasks Executed by Small Communes, whose result was two books (Lisowska, Kobielska 2013; Lisowska, Kobielska 2014). On the basis of international standards and previous research experiences, the authors will select the good governance principles that were applied in the presented research. 
A definition of good governance requires that first the very category of governance be referred to. In his critical analysis of the notion of governance, Claus Offe indicates that "the contemporary proliferation of this term stands in sharp contrast to its informative content; to say governance does not mean to express a lot because of the term's ambiguity" (Offe 2016: 342). Offe is of the opinion that the category of governance belongs to so-called empty signifiers and its popularity results from normative demands hidden in it and reconciling the issue of the state's intervention and efficiency with the need for social autonomy (Ibidem: 344). Taking into consideration these comments, we should, however, depict the most characteristic features of this notion, and hence the way in which it is understood by the authors, because the objective scope of the assessment of the quality of governance in the communes of the Opolskie province should be interpreted on this basis.

According to Francis Fukuyama, governance is "the government's ability to create and enforce rules and to provide services, irrespective of whether the government is democratic or not" (Fukuyama 2013: 3). In Fukuyama's opinion, governance concerns the state's executive apparatus and its ability to implement efficiently priorities determined outside this apparatus, i.e. by politicians, therefore, also "an authoritarian regime can be governed well" (Ibidem: 4). A broader definition of governance is provided by the World Bank, which defines governance as "traditions and institutions by means of which power is exercised in the state" (Kaufman et al. 2010: 4). Next, World Bank researchers distinguish the following three aspects of governance (Ibidem):

a) processes within which governments are elected, supervised, and replaced,

b) a government's ability to formulate and implement reasonable policies effectively,

c) citizens' and the state's respect for institutions responsible for the regulation of social and economic interactions.

Thus, governance concerns processes and rules through which power is exercised as well as the results of the exercise of power. Already mentioned above, Offe writes that the notion of governance "is used in order to grasp, on the one hand, institutions (...), and on the other - the process (of steering) taking place within such institutions" (Offe 2016: 337). However, if we take a close look at the third component of governance distinguished by the World Bank, what we can also see there is a place for citizens as participants of governance. Bob Jessop emphasizes that the growing popularity of this term is connected with the necessity to distinguish between co-management and governance - the former would refer to various methods of governance, while the latter to a government and its 
institutions equipped with the possibility to govern. The need for such a distinction is connected with the previous paradigms' inability to explain the changing organization and distribution of power - the traditional dichotomies such as market vs. hierarchy in the economy or private vs. public in politics appear to be simplifications which do not fit contemporary reality (Jessop 2016: 13).

In this context, it should be noted that the translation of the English notion of governance in the Polish academic discourse often functions as co-governing or co-management because the word governance does not refer only to the state and its institutions, being in fact a negation of the Weberian tradition of thinking about the role of the state (Hausner, Mazur 2016: 354). The concept of governance understood as co-governing assumes that the state is only one of the many subjects of governance oriented towards acting jointly with other centers of power possessing resources ensuring subjectivity; additionally, their subjectivity is accepted by the state apparatus and included in the process of co-management. Thus, the state functions in the conditions of the decentralization of power, and its competencies are limited for the benefit of networks of interests existing at various levels of social organization and bottom-up initiatives (Hausner, Mazur 2016: 354-355). Therefore, the notion of governance is of a relational and processual character because it takes into consideration the role of all entities which are the most important in a given context and potentially involved in the process of making decisions about public matters as well interactions among them. The essence of this understanding of governance is conveyed in the definition proposed by Transparency International according to which governance goes "beyond the traditional notion of government and focuses on relations among political leaders, public institutions, and citizens as well as processes through which they make and implement decisions" (Transparency International 2009: 22). Governance understood in this way means that the objects of governance quality assessments at the commune level are not only formalized governing bodies but also other entities which could play the co-governing role in the local setting. Applying the concept of governance to communes, Sigmund Barczyk writes that "local government, as a sovereign constitutional body, factually takes advantage of particular institutional attributes in matters of key importance for the functioning and development of communes, but it simultaneously seeks an arrangement of joint decision making relations with other partners of the commune game that would be the most advantageous for communes" (Barczyk 2010: 160). Thus, a general assessment concerns the condition of a whole local community consisting of many more or less institutionalized actors. Additionally, official governing bodies play obviously a key role as the administrators of important public resources. This scope of assessment is reflected in the principles and indicators of 
the quality of governance selected for the purposes of this study many of which consist in assessing the condition of a local community rather than the condition of local political institutions. Obviously, between these two dimensions there exist interactions and relationships which the authors attempt to present in more detail in the descriptions of the particular indicators. At this point, the authors want only to emphasize that the final governance quality assessment to be scored by the particular communes on the basis of the measurement methodology proposed here should be interpreted with respect to the comments above.

Measuring the quality of governance requires an answer to the fundamental question, namely: When can governance be referred to as good? Contrary to the stand taken by Fukuyama, a governance quality assessment is rooted in the axiology of the Western democracies, which formulates objectives to be pursued by those who govern (Wilkin 2013: 32-34). It is possible to distinguish international and national sources of criteria of good governance which constitute a normative point of reference for the assessment of the quality of governance in concrete political units. Tab. 3 presents four such sources. It should be kept in mind that they are just a few of many examples, although more representative ones ${ }^{14}$. A comparison of these sources indicates similarities with respect to the criteria of good governance ${ }^{15}$ - the principles of accountability, efficiency, participation, or openness belong to the repertoire of good governance functioning in the global discourse on the quality

of governance ${ }^{16}$. Among the standards above, what is a source of particular importance because of its dedication to the local level is The Strategy for

14 A review of the criteria and indicators of good governance in various approaches $\mathrm{cf}$. (Wojciechowski, Podgórniak -Krzykacz 2008; Łopaciuk-Gonczaryk 2013; Borys 2014).

15 This similarity is particularly visible in the case of $\mathrm{EU}$ and Polish sources, which appears to be an effect of the implementation of these principles in Poland in consequence of its accession to the European Union. The fulfilment of the so-called Copenhagen criteria, the prerequisite for joining the $\mathrm{EU}$, meant the necessity to build a system of the rule of law and institutions guaranteeing stable democracy. Subsequently the concept of good governance appeared in the so-called first programming period in the 2007-2013 national strategic reference framework and later became a foundation for priority $\mathrm{V}$ in the Human Capital Operational Programme.

16 The notion of "the global discourse on the quality of governance" may be understood as referring to the major international organizations whose aims include the improvement of the quality of governance, governments cooperating with such institutions, nongovernmental organizations, and researchers that jointly create objectivized knowledge and values (standards, recommendations, research reports, commentaries, seminars, conferences) rooted in the ideal of a well-arranged state. Here the inspiration was the notion of a global anti-corruption industry proposed by Stephen Sampson (Sampson 2010). 
Tab. 3: Selected sources of the principles of good governance

\begin{tabular}{llll}
\hline international sources & & domestic sources \\
\hline World Bank (1996) & $\begin{array}{l}\text { European Union } \\
\mathbf{( 2 0 0 1 )}\end{array}$ & $\begin{array}{l}\text { Council of } \\
\text { Europe (2007) }\end{array}$ & $\begin{array}{l}\text { Poland's Ministry of } \\
\text { Regional Development } \\
\mathbf{( 2 0 0 8 )}\end{array}$ \\
\hline $\begin{array}{llll}\text { 1. Accountability and } \\
\text { participation }\end{array}$ & $\begin{array}{l}\text { 1. Openness } \\
\text { 2. Participation }\end{array}$ & $\begin{array}{l}\text { The 12 principles } \\
\text { of good }\end{array}$ & $\begin{array}{l}\text { 1. Openness } \\
\text { 2. Partnership }\end{array}$ \\
$\begin{array}{l}\text { 2. Political stability and } \\
\text { absence of violence }\end{array}$ & $\begin{array}{l}\text { 3. Accountability } \\
\text { governance at the }\end{array}$ & $\begin{array}{l}\text { 3. Accountability } \\
\text { local level such } \\
\text { as fair elections, }\end{array}$ & $\begin{array}{l}\text { 4. Efficiency } \\
\text { 5. Effectiveness and } \\
\text { cohesion }\end{array}$ \\
$\begin{array}{l}\text { 3. Government's } \\
\text { effectiveness }\end{array}$ & $\begin{array}{l}\text { 5. Cohesion } \\
\text { participation, } \\
\text { responsiveness, } \\
\text { efficiency, }\end{array}$ & \\
$\begin{array}{l}\text { 5. Rulity of regulations } \\
\text { 6. Fight with corruption }\end{array}$ & & $\begin{array}{l}\text { transparency, } \\
\text { accountability }\end{array}$ & \\
\hline
\end{tabular}

Source: the authors' own work based on: D. Kaufmann, A. Kraay, M. Mastruzzi, Governance Matters VI: Governance Indicators for 1996-2006, World Bank Policy Research Working Paper No. 4280, 2007; European governance: a white paper, European Commission, COM(2001) 428, Brussels, 25.7.2001; Strategy for Innovation and Good Governance at Local Level - Extract from the Valencia Declaration 15th Conference of European Ministers Rresponsible for Local and Regional Government (2007), Appendix I, Council of Europe, Valencia, 15-16 October; Koncepcja good governance - refleksje do dyskusji, Ministerstwo Rozwoju Regionalnego, Warszawa 2008.

Innovation and Good Governance at Local Level adopted by the Council of Europe, which, according to its fragment, is also based on the experiences of other international organizations ('Strategy' 2007). This strategy includes twelve principles of good governance at the local level:

1. Fair elections, representation and participation in order to provide all citizens with opportunities to express their opinions on local public matters.

2. Responsiveness in order to ensure that local authorities address citizens' legal expectations and needs.

3. Efficiency and effectiveness in order to ensure the achievement of formulated objectives based on the best possible use of resources.

4. Openness and transparency in order to ensure public access and information and facilitate addressing and dealing with local public matters.

5. The rule of law in order to ensure fairness, impartiality, and predictability.

6. Ethical behavior in order to ensure the priority of public interests over private ones.

7. Competencies and talents in order to ensure the proper fulfilment of duties by local officers and representatives. 
8. Innovation and openness to change in order to ensure the advantageous use of new solutions and good practices.

9. Sustainable development and long term orientation in order to take into consideration the interests of future generations.

10. Prudent financial management in order to ensure the sagacious and productive use of public funds.

11. Human rights, cultural diversity, and social cohesion in order to ensure that all citizens can enjoy safety and respect and that nobody is discriminated against or excluded.

12. Accountability in order to ensure that local officers and representatives assume responsibility and may be brought to justice for their actions.

The set of principles proposed by the Council of Europe shows the multidimensional character and complexity of the assessment of local politics, but also a wide range of possible directions of research on its quality. This is reflected in international research experiences. In A Practical Guide to Measuring Governance at the Local Level mentioned above, we can read that research on the quality of local governance focuses the most often on the following four topics (Wilde et al. 2009: 8):

1. decentralization - what is studied in this case is the degree and forms of decentralization (e.g. devolution, delegation), taking into consideration the fiscal, administrative and political dimensions of decentralization, as well as the national decentralization environment, i.e. institutions, acts of parliament, and policies at the central level.

2. local governance - in this case, the subject matter of research is the basic dimensions and determinants of local governance such as a local political system (the rule of law, elections, civil liberties, access to information, the strength of the civil society), elected institutions and their functioning (public procurement, financial policy, corruption), social issues (gender equality, environmental protection, ensuring tax revenues), and a business environment.

3. local democracy - in this case, research focuses on the procedure of electing local authorities, the role of civic organizations, and the influence of minority and opposition groups on the process of governance; the subject matter of analysis is formal mechanisms guaranteeing the transparency, representativeness, and accountability of authorities, as well as the practical functioning of these mechanisms from the point of view of citizens.

4. local authorities and their achievements - in this case, researchers concentrate on the results of local politics expressed in the quality of goods and services provided to the self-governing community; the subject matter of analysis 
is the quality of services in one or more selected sectors of local authorities' activities (such research is often accompanied by an analysis of financial, institutional, and human resources aimed at assessing local authorities' abilities to carry out particular programs and tasks).

Tab. 4 presents examples of tools developed to assess the quality of governance at the local level together with their normative orientation, that is dimensions constituting the subject matter of analysis. The repertoire of evaluation criteria is very similar to the standards developed for the national level; additionally, at the local level there appears an additional dimension referred to as "equity". A more thorough analysis of such tools shows that the dimension of "equity" is understood to a large extent as the existence of institutional solutions preventing the exclusion of certain social categories or a state of relative equality within a local community ${ }^{17}$. In view of the fact that it is a certain additional dimension which appears to be diversifying slightly the axiology of measuring the quality of governance at the local and national levels, the authors decided to choose it as one of the good governance criteria at the commune level. They also decided to use the notion of "equality" instead of the notion of "equity" since the former appears to be a category that is less encumbered axiologically.

On the basis of the analyses above, the authors decided to distinguish the following five principles of good governance: equality, effectiveness, accountability, openness, and participation. Each of the principles was assigned 5 indicators allowing an assessment of the quality of governance with respect to compliance with a given principle. The indicators are of a diversified character because they are so-called focused indicators related to input, output, and processes in contrast to perception-focused indicators (Wilde et al 2009) for which no relevant data

17 In the case of the Municipal Governance Index, the principle of equity was operationalized by means of the following indicators: 1 . The existence of a civil rights charter guaranteeing the right of access to basic public services 2 . The percentage of women in the municipal council 3. The percentage of women in key positions 4 . The pursuit of a special water fee policy targeted at people living in poverty 5 . The use of a system of incentives to undertake informal business activities. According to the Local Governance Barometer, equity consists of the following elements: 1. Legal guarantees of protection for civil rights 2. A degree of access to participation in the exercise of power 3. A degree of access to work and income 4. A degree of access to health care and education 5. A degree of exposure to the risk of domestic violence. On the other hand, in the case of the Good Governance Index for Local Development, equity comprises the following elements: 1 . Conducting affirmative actions for those living in poverty 2. Conducting affirmative actions for women (Wilde et al. 2009: 56-75). 


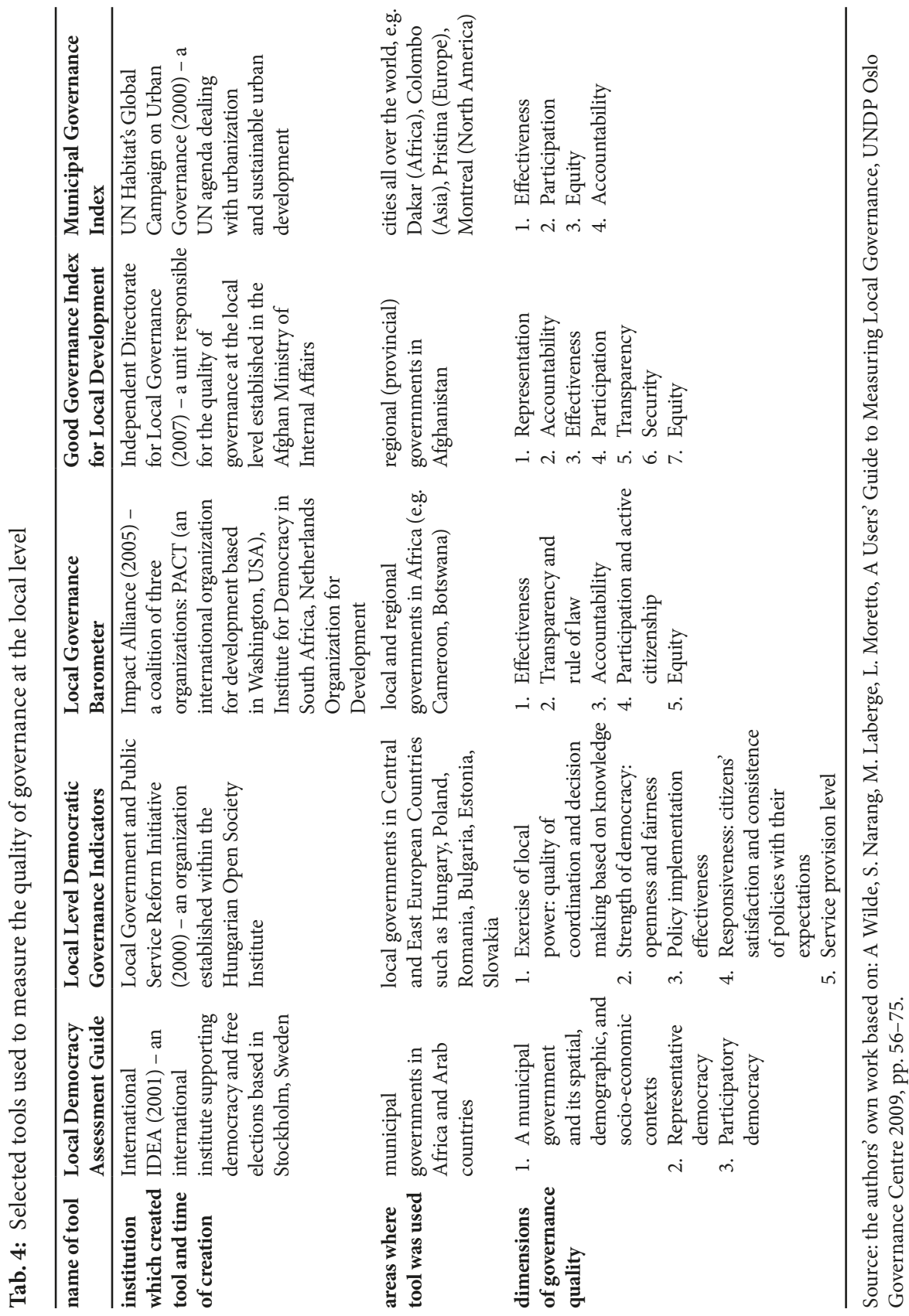


are available. Efforts were made to ensure that the indicators met certain basic requirements indicated by Tadeusz Borys. According to Borys, the indicator of the quality of governance at the commune level should be characterized by the following features: a) it should constitute a substantive reflection of a given dimension of governance, b) it should be easy to interpret, c) it should allow the monitoring of changes in time, d) it should allow comparisons among communes, e) it has to have a referential value, $f$ ) its validity should be based on a consensus, $g$ ) it should be formulated in a manner facilitating its use in information systems, $h$ ) it should be measurable, that is based on available, documented, reliable, and updated data (Borys 2014: 64-65). A detailed description (essence, data sources, period, weaknesses) of each of the selected indicators is presented in the annex. At this point it should be noted that the selected indicators range in value from 0 to 1 , therefore, the maximum number of points to be scored by a commune in the assessment of the particular principles of good governance was 25 . This was the basis for creating the commune-level governance quality index consisting of five sub-indexes of the same weight (cf. Tab. 5). The subsequent paragraphs present the authors' understanding of each of the principles and the resultant selection of indicators.

Under the notion of equality, the authors understand a degree to which groups traditionally exposed to exclusion are represented in a commune's public life. This definition causes the need to look for the indicators of such equality to be found at the commune level. On the basis of these characteristic features, the authors selected equality indicators concerning the following four social groups exposed to the risk of exclusion: women, the elderly, the youth, the poor $^{18}$. It should be noted that some of the selected equality indicators may be also regarded as participation indicators because, for example, a senior citizens council is simultaneously a participatory body. It is one of the problems related to the measurement of the particular governance quality principles resulting from the fact of substantive connections among the particular principles. For example, participation may simultaneously fulfil the role of an accountability mechanism and increase equality in a local public space. It seems that deciding about assigning a particular indicator to a given principle of good governance, the researcher has to exercise some degree of discretion.

18 The authors are aware that social categories are not disjunctive, i.e. those exposed to the risk of poverty are simultaneously elderly women or young people in long term unemployment. Thus, in practice, a particular indicator comprises a few social categories. For example, an active senior citizens council may represent the interest of not only elderly people but also women living in poverty. 
The notion of effectiveness should be understood as the degree to which the local authorities perform their obligations to the self-governing community with respect to the fulfilment of their needs and reasonable management of the commune's property. Let us focus on the problems related to the assessment of effectiveness. From the perspective of assessment-related procedures in local government units, effectiveness is "a relation among products, results and (especially financial) resources allocated for their achievement" (Grzywa 2008: 15). Thus, effectiveness is an economic category and its essence is achieving formulated objectives by reasonably managing available resources - effective means achieving the best possible results with the least possible expenditures. In order to ensure such effectiveness in the functioning of public administration units management processes need to be based on strategic planning, control of expenses, policies oriented towards savings, simplification of procedures, and improvement of the quality of provided services (Żołnierczyk, Szumowski 2014: 122-124). With respect to measurement, a literal treatment of effectiveness constitutes a challenge because it requires that expenditures and expected results be defined precisely. Even if such a relation can be determined, there appears a problem with allocating particular values to expenditures and especially to results as well as assessing such values with respect to the optimal utilization of available resources. While it is possible to determine a commune's expenditures on primary education or promotional activities, it is rather difficult to assess the value of the effects of incurring such expenditures, particularly if such effects are postponed in time and are influenced by other factors. Therefore, the selected effectiveness indicators are only partly compatible with this abstract category. On the one hand, these indicators refer to the economic results of a commune's policy concerning the acquisition of financial resources (its own revenues) and the use of such resources for development purposes (capital expenditures and fight with chronic poverty). On the other hand, two indicators refer to the functioning of a commune's administration in terms of applied procedures aimed at increasing effectiveness and expenditures on administration.

Accountability should be understood as mechanisms and competences allowing the enforcement of local political decision makers' liability for their decisions. The principle of accountability creates special difficulties with finding relevant indicators allowing its measurement as well as comparison among communes. As Mark Bovans writes, accountability is a social relation between an actor and a forum within which the actor is obliged to explain and justify their actions, the forum may ask questions and make judgements, and the actor may take the consequences of their actions. Obligations to provide explanations may have an either formal or informal character, similarly to the consequences taken by the 
Tab. 5: The Local Level Governance Quality Index (25 points)

\begin{tabular}{|c|c|c|c|c|}
\hline $\begin{array}{l}\text { equality } \\
\text { sub-index } \\
5 \text { (points) } \\
\end{array}$ & $\begin{array}{l}\text { efficiency } \\
\text { sub-index } \\
5 \text { (points) }\end{array}$ & $\begin{array}{l}\text { accountability } \\
\text { sub-index } \\
5 \text { (points) }\end{array}$ & $\begin{array}{l}\text { openness } \\
\text { sub-index } \\
5 \text { (points) }\end{array}$ & $\begin{array}{l}\text { participation } \\
\text { sub-index } \\
5 \text { (points) }\end{array}$ \\
\hline $\begin{array}{l}\text { To what } \\
\text { degree are the } \\
\text { groups typically } \\
\text { exposed to } \\
\text { social exclusion } \\
\text { represented } \\
\text { in local public } \\
\text { life? }\end{array}$ & $\begin{array}{l}\text { To what degree } \\
\text { do the local } \\
\text { authorities } \\
\text { perform their } \\
\text { obligations to the } \\
\text { self-governing } \\
\text { community } \\
\text { with respect to } \\
\text { the fulfilment } \\
\text { of their needs } \\
\text { and reasonable } \\
\text { management of } \\
\text { the commune's } \\
\text { property? }\end{array}$ & $\begin{array}{l}\text { To what } \\
\text { degree are the } \\
\text { mechanism and } \\
\text { competences } \\
\text { allowing the } \\
\text { enforcement of } \\
\text { the local political } \\
\text { decision makers' } \\
\text { liability for } \\
\text { their decisions } \\
\text { functional and } \\
\text { effective? }\end{array}$ & $\begin{array}{l}\text { To what degree is } \\
\text { information on } \\
\text { the actions of the } \\
\text { local authorities } \\
\text { made publicly } \\
\text { available? To } \\
\text { what degree } \\
\text { do the local } \\
\text { authorities } \\
\text { cooperate with } \\
\text { the local social } \\
\text { environment? }\end{array}$ & $\begin{array}{l}\text { To what degree } \\
\text { is the local } \\
\text { community } \\
\text { involved in local } \\
\text { public life? }\end{array}$ \\
\hline $\begin{array}{l}\text { 1. The } \\
\text { percentage } \\
\text { of women } \\
\text { in the } \\
\text { commune } \\
\text { council. }\end{array}$ & $\begin{array}{l}\text { 1. Investment } \\
\text { expenditures } \\
\text { from the } \\
\text { commune } \\
\text { budget per } \\
\text { capita. }\end{array}$ & $\begin{array}{l}\text { 1. The } \\
\text { existence of } \\
\text { a local media } \\
\text { organization } \\
\text { that is not } \\
\text { controlled by } \\
\text { the commune } \\
\text { authorities. }\end{array}$ & $\begin{array}{l}\text { 1. The } \\
\text { commune's } \\
\text { responding } \\
\text { to the } \\
\text { questionnaire } \\
\text { by the set } \\
\text { deadline. }\end{array}$ & $\begin{array}{l}\text { 1. The number } \\
\text { of non- } \\
\text { governmental } \\
\text { organizations } \\
\text { in the } \\
\text { commune } \\
\text { per } 10,000 \\
\text { inhabitants. }\end{array}$ \\
\hline $\begin{array}{l}\text { 2. The } \\
\text { percentage } \\
\text { of women } \\
\text { holding key } \\
\text { positions } \\
\text { in the } \\
\text { commune } \\
\text { office. }\end{array}$ & $\begin{array}{l}\text { 2. The } \\
\text { commune's } \\
\text { own revenues } \\
\text { per capita. }\end{array}$ & $\begin{array}{l}\text { 2. The } \\
\text { publication } \\
\text { of internal } \\
\text { inspection } \\
\text { reports in } \\
\text { the Public } \\
\text { Information } \\
\text { Bulletin. }\end{array}$ & $\begin{array}{l}\text { 2. Easy access } \\
\text { to and } \\
\text { availability of } \\
\text { a valid annual } \\
\text { programme of } \\
\text { cooperation } \\
\text { with non- } \\
\text { governmental } \\
\text { organization } \\
\text { in the Public } \\
\text { Information } \\
\text { Bulletin or on } \\
\text { the commune } \\
\text { office's } \\
\text { website. }\end{array}$ & $\begin{array}{l}\text { 2. The number } \\
\text { of library } \\
\text { members } \\
\text { per } 1000 \\
\text { inhabitants. }\end{array}$ \\
\hline
\end{tabular}


Tab. 5: Continued

\begin{tabular}{|c|c|c|c|c|}
\hline $\begin{array}{l}\text { equality } \\
\text { sub-index } \\
5 \text { (points) }\end{array}$ & $\begin{array}{l}\text { efficiency } \\
\text { sub-index } \\
5 \text { (points) }\end{array}$ & $\begin{array}{l}\text { accountability } \\
\text { sub-index } \\
5 \text { (points) }\end{array}$ & $\begin{array}{l}\text { openness } \\
\text { sub-index } \\
5 \text { (points) }\end{array}$ & $\begin{array}{l}\text { participation } \\
\text { sub-index } \\
5 \text { (points) }\end{array}$ \\
\hline $\begin{array}{l}\text { 3. The } \\
\text { activities of } \\
\text { the youth } \\
\text { council. }\end{array}$ & $\begin{array}{l}\text { 3. The } \\
\text { percentage } \\
\text { of people } \\
\text { using social } \\
\text { assistance } \\
\text { services on } \\
\text { a long-term } \\
\text { basis in } \\
\text { relation to } \\
\text { all people } \\
\text { receiving } \\
\text { social benefits. }\end{array}$ & $\begin{array}{l}\text { 3. The number } \\
\text { of candidates } \\
\text { for the } \\
\text { position of } \\
\text { commune } \\
\text { leader/ } \\
\text { mayor in the } \\
\text { 2014 local } \\
\text { government } \\
\text { elections. }\end{array}$ & $\begin{array}{l}\text { 3. The passing } \\
\text { of a resolution } \\
\text { determining } \\
\text { the rules and } \\
\text { procedures } \\
\text { of social } \\
\text { consultations. }\end{array}$ & $\begin{array}{l}\text { 3. The average } \\
\text { mark in } \\
\text { the junior } \\
\text { secondary } \\
\text { school } \\
\text { examination in } \\
\text { the knowledge } \\
\text { of society and } \\
\text { history. }\end{array}$ \\
\hline $\begin{array}{l}\text { 4. The } \\
\text { activities of } \\
\text { the senior } \\
\text { citizens } \\
\text { council. }\end{array}$ & $\begin{array}{l}\text { 4. Expenditures } \\
\text { on the public } \\
\text { administration } \\
\text { per } 1 \\
\text { inhabitant. }\end{array}$ & $\begin{array}{l}\text { 4. The } \\
\text { publication } \\
\text { of the } \\
\text { councillors' } \\
\text { and the } \\
\text { commune } \\
\text { leader's } \\
\text { property } \\
\text { statements } \\
\text { in the Public } \\
\text { Information } \\
\text { Bulletin } \\
\text { before } \\
2 \text { June } 2017 \text {. }\end{array}$ & $\begin{array}{l}\text { 4. The number } \\
\text { of non- } \\
\text { governmental } \\
\text { organizations } \\
\text { which have } \\
\text { submitted } \\
\text { comments } \\
\text { on the } \\
\text { programme of } \\
\text { cooperation } \\
\text { with non- } \\
\text { governmental } \\
\text { organizations. }\end{array}$ & $\begin{array}{l}\text { 4. Funds from } \\
\text { the } 1 \% \\
\text { mechanism } \\
\text { acquired by } \\
\text { the commune's } \\
\text { public benefit } \\
\text { organizations } \\
\text { per capita. }\end{array}$ \\
\hline $\begin{array}{l}\text { 5. The degree } \\
\text { of the } \\
\text { poverty risk. }\end{array}$ & $\begin{array}{l}\text { 5. The } \\
\text { commune's } \\
\text { usage of } \\
\text { one of the } \\
\text { three quality } \\
\text { management } \\
\text { systems. }\end{array}$ & $\begin{array}{l}\text { 5. The } \\
\text { percentage } \\
\text { of the } \\
\text { councillors } \\
\text { with higher } \\
\text { education. }\end{array}$ & $\begin{array}{l}\text { 5. The } \\
\text { publication } \\
\text { of commune } \\
\text { council } \\
\text { session } \\
\text { minutes in } \\
\text { the Public } \\
\text { Information } \\
\text { Bulletin. }\end{array}$ & $\begin{array}{l}\text { 5. The percentage } \\
\text { of votes cast for } \\
\text { voters' election } \\
\text { committees in } \\
\text { relation to the } \\
\text { total number } \\
\text { of votes cast in } \\
\text { the commune } \\
\text { council } \\
\text { elections. }\end{array}$ \\
\hline
\end{tabular}

Source: the authors' own work. 
actor for their actions before the forum. Additionally, the very risk of the occurrence of particular consequences may be regarded as an accountability mechanism (Bovans 2006: 9). Looking for fora before which local political actors are accountable for their actions, we should first of all mention external institutions responsible for supervision over the local government system and specified in Article 171 of the constitution, that is the President of the Council of Ministers, provincial governors, regional accounting chambers, and the Sejm, which has the authority to dissolve a commune council ('Constitution' 1997). Supervision over the activities of local governments is also exercised by the Supreme Chamber of Control or the Central Anti-corruption Bureau ${ }^{19}$. These are external bodies exercising the controlling function, but there are also internal control mechanism such as managerial control obligatory under the Public Finances Act and the related secondary legislation (Małecka-Łyszczek 2015: 243-250). It is also possible to indicate social control that is exercised in the course of local government elections, local referenda, and local media, as well as by means of complaints and requests submitted under the Code of Administrative Proceedings.

However, from the perspective of this research, there appears a certain major problem because the existing accountability mechanisms have been designed as a part of the position of the commune and supervision over the commune within the structure of the political system and are applicable to all communes. Therefore, in order to differentiate among the communes with respect to the degree of accountability, we should compare the communes of the province with respect to the frequency of using such mechanisms in each commune. It is not only a problem of access to data, but rather a problem of their interpretation as measures of a degree of accountability. If the provincial governor or the regional accounting chamber issues a negative opinion on commune $\mathrm{A}$ and commune $\mathrm{B}$ does not receive any such opinion, does it allow us to conclude that commune A has a higher level of accountability (irregularities have been identified) than that of commune B? After all, commune B may be subject to equally strict inspections as commune $\mathrm{A}$, but there are no irregularities in commune $\mathrm{B}$, while they are detected in commune $\mathrm{A}$. In such cases, negative opinions should be regarded rather as a measure of the legality of activities or bad financial management in commune $\mathrm{A}$ in comparison to commune $\mathrm{B}$ or possibly a

19 Article 1 of the Act on the Central Anti-corruption Bureau declares that it is an institution responsible for fighting corruption, "particularly in state and local government institutions". The Central Anti-corruption Bureau Act of 9 June 2006 (Journal of Laws of 2016, item 1310). 
measure of the effectiveness of external control institutions. But such inspections cannot be used to compare the degrees of accountability among communes as they are connected with the functioning of supra-communal mechanisms. The cases of irregularities or corruption ascertained by the Supreme Chamber of Control or the Central Anti-corruption Bureau concern a few communes only and are rather a measure of the quality of commune governance ${ }^{20}$. There is also a lack of access to data concerning managerial control, which would make it possible to compare communes on a regular basis (e.g. reports on the status of managerial control which are to be drawn up by managers of particular organizational units are rarely published in Public Information Bulletins). On the other hand, there are so few cases of dismissing a commune leader/mayor or commune/town council in the Opolskie province that no systematic qualitative comparisons are possible ${ }^{21}$. Complaints and requests submitted by commune inhabitants could constitute a source of comparable knowledge on accountability in the communes, but also in this case we face the problem of access to data and their interpretation. Not all communes answered the questionnaire, in which the authors asked, among other things, about citizens' complaints and requests, and the Public Information Bulletin did not suffice to complement the missing information. Furthermore, the number of complaints and requests may be interpreted on the one hand as a measure of commune inhabitants' readiness to control the authorities by means of this instrument, but on the other hand a large number of complaints and requests may be a measure of a low effectiveness of the local bureaucracy (and hence a lower quality of governance). Thus, a larger number of complaints and requests cannot be regarded as a positive phenomenon ${ }^{22}$. An election turnout could be used as one of the indicators of

20 Nevertheless, post-inspection data may be used in developing a commune accountability indicator, which is discussed in more detail in the annex.

21 According to the data of the State Electoral Commission, since 199317 dismissal referenda have been held in the Opolskie province (status as at 20 August 2017) (there have been two simultaneous referenda concerning the dismissal of both a council and a mayor): 3 have concerned district councils, 9 - town councils, 2 - commune councils, 1 - a town president, 3 - mayors, and 1 - a commune leader. Among these referenda there was only one successful dismissal of town council - in Niemodlin in 2001. Cf. http://opole.kbw.gov.pl/352_Wybory_i_referenda.

22 Nevertheless, it seems that the institution of a request submitted by a citizen under the Code of Administrative Proceedings may be a better measure of social accountability in comparison to the instrument of a complaint because of the differences between these two instruments. A complaint concerns actions that have already taken place or 
accountability at the commune level, but, for reasons described in the following sections, the authors decided not to use the data concerning participation in elections. Consequently, the selected indicators and their pertinence should be assessed taking into consideration the difficulties outlined above. The authors tried to identify such mechanisms and competencies that function strictly at the local level, can occur in all communes, adopting various values, and can be assessed quantitatively on the basis of reliable data.

The notion of openness should be understood as regularly publishing information on the activities of local authorities and the active cooperation of such authorities with the social/institutional environment. Openness is a quite wide-ranging category as it combines such qualities as transparency, readiness/ ability of authorities to cooperate with other social life actors, and readiness/ ability to undertake innovative actions (Lisowska 2014: 79-85). It seems that the central features of openness are transparency, partnership and cooperation with the social environment. Understood in this way, openness is an important supplement to and a condition for accountability because without the knowledge of authorities' actions and the rules of their functioning ensured by transparency, it is difficult to bring them to account ${ }^{23}$. On the other hand, cooperation between authorities and the social environment results in the necessity to accept assessments given by partners, to take into consideration their needs and expectations, and to justify made decisions. Openness is also close to equality because it requires the acknowledgement of the subjectivity of various social stakeholders - to some extent, these two principles overlap as the degree to which groups exposed to social exclusion are represented in the social space is also a measure of the openness of the system of power to the interests of such groups.

The notion of participation should be understood as the degree to which a local community is involved in the local public life. Understood in this way, participation is to a considerable extent identical to the strength of the local civil society whose primary feature is the involvement of private entities in the pursuit of public objectives (Szacki 1997). Research on social participation at the

are being performed and cause negative opinions of stakeholders, while a request is a demand to eliminate certain irregularities in the future. Thus, a request is of a preventive character and, unlike a complaint, is often submitted in the social interest (Kurzawa 2015: 235).

23 Therefore, transparency itself is only one of the conditions for preventing corruption and its anti-corruption potential is unlocked only when information on the actions of authorities reaches the public in a system including accountability mechanisms (Naurin, Lindstedt 2005: 6-10). 
local level usually focuses on various manifestations of civic activity and is used to assess the quality of the civil society - in such research, the notion of social participation is used interchangeably with the notion of civic participation or civil society (Skrzypiec 2002: 12; Pietraszko-Furmanek 2012: 62-65). Civic participation is regarded as one of the integral principles of good governance, which results from the very idea of joint governing included in the notion of governance, although it should be noted that there are studies in which participation is also regarded in the category of social capital and is then distinguished as a separate dimension interacting with the quality of governance (Łopaciuk-Gonczaryk 2013). In the presented study, an assessment of civic participation is an assessment of one of the dimensions of the quality of governance since the authors assume that the presented definition of governance obliges the researcher to assess the condition of a whole self-governing community together with its infrastructure of social and political institutions, and not just the state of the institutions of local political representation. Therefore, in their research, the authors took into consideration broadly understood civic participation, i.e. both individual and collective actions which need not be of a purely political character (e.g. voting for candidates from inhabitants' election committees), but may be interpreted as a manifestation of a sense of responsibility for the public good and the possession of relevant resources making it possible to pursue the public good (e.g. civic competencies or the strength of a local non-governmental sector).

It should be noted that in this study, the authors did not use the data concerning the election turnout as an indicator of civic participation or accountability, although such data are often used as one of the indicators of the quality of governance as they are easily available. This results from the unique character of the Opolskie province, where the problem of election data reliability occurs because of so-called suspended migration. Romuald Jończy, one of the leading authorities in the field of research on migration in the Opolskie province, has estimated that in 2006, $25 \%$ (approximately $80,000-85,000$ people) of the Germans living in the region were people who had emigrated permanently, but were still officially registered as residing in the Opolskie province. This constitutes $8 \%$ of the province's population; however, if the geographical distribution of this group is taken into consideration, it becomes evident that suspended emigration is typical primarily of the communes examined in this research, that is rural communes with a high percentage of Silesian and German populations (Jończy, Łukaniszyn-Domaszewska 2014: 19-21). Therefore, the authors decided not to use the data concerning the election turnout because the possibly lower turnout in these communes may be the effect of suspended migration. 
As it has been mentioned above, a detailed description of each of the indicators is included in the annex. What should be indicated at this point are general problems with which the authors had to cope while looking for governance quality indicators at the commune level. Firstly, a particular indicator may be assigned to different principles of good governance, because these principles overlap. As a result the researcher faces the problem of discretionary assigning a particular indicator to a given principle of good governance. Secondly, the indicators provide information about the current state only, while conclusions concerning the conditions and consequences of such a state (that is about the governance processes whose measurement constitutes the core of the research) are, in a sense, a theoretical speculation that would require an in-depth empirical verification at the level of each commune. Thirdly, some indicators are the basis for evaluating communes in the area which, although included in the range of communes' own tasks, is also influenced by external influences that are rather difficult to assess. Consequently, a commune may be assessed for something over which it has a limited control. The last problem concerns data on the local reality. In Poland, a lot of quantitative data allowing comparisons among territorial units concern districts and provinces (e.g. the Local Data Bank of the Central Statistical Office $)^{24}$. Therefore, the selection of the governance quality indicators at the local level is determined rather by the availability of relevant data. Thus, sometimes what is researched is not what the researcher finds interesting, but what can be researched thanks to available data. Assessing the relevance and reliability of the methodology of measuring the quality of governance proposed in this study, one should take into consideration the aforementioned problems.

24 Aldona Podgórniak-Krzykacz observed that the problem with the availability of statistical data allowing the measurement of good governance occurs already at the level of provinces (Podgórniak-Krzykacz 2013: 173). 


\section{A characterization of the Opolskie province. Cultural diversity as a distinctive feature}

This chapter is devoted to a characterization of the Opolskie province as a separate region, with a particular focus on the region's history of multiculturalism, its changes after 1944, and the present state of its ethnic diversity. The final part of the chapter will be devoted to relations between the multiculturalism of the region and the quality of governance as perceived by other researchers.

The Opolskie province is Poland's most diversified region in terms of ethnicity (Barwiński 2006). At the same time, with respect to its ethnic constitution, Poland is one of the most homogeneous countries in Europe (cf. Alesina et al. 2003; Fearon 2003), which puts these deliberations on the dynamics of changes in ethnic diversity in a rather specific light. In our research, an example of a multicultural region is a province where $88 \%$ of inhabitants declare their identification with the majority group. From this perspective, the phenomenon of the imagined "multiculturalism" of Silesia, including the Opolskie province, is the consequence of the contrast between the discourse on the ethnic "purity" of Poland initiated in the 1950s and the fact of minority groups' identification with other nationalities or ethnic groups. Nevertheless, the multiculturalism of the Opole Region is an interesting research topic in the context of the ongoing debate on national and regional minorities in Poland (Barwiński 2014; 2016; 2017; Łodziński 2016; Rykała 2014; Rykała and Sobczyński 2016), the influence of ethnic diversity on social and political life (Putnam 2007; Schaeffer 2013), as well as the historical tradition of multiculturalism of this part of Europe.

\section{The Opolskie province as a region}

The administrative reform conducted in Poland in 1999 resulted in the establishment of 16 provinces which replaced the previous arrangement of 49 provinces (introduced in 1975). The Opolskie province existed as an administrative region both before and after the reform. What changed, however, was the area of the province. In comparison to its territory before 1999, the Opolskie province was enlarged by the communes of Dobrodzień, Olesno, Gorzów Śląski, Praszka, Radłów, and Rudniki, which had belonged to the Częstochowskie province before the reform. Two of these communes - Praszka and Rudniki - do not belong to the historical territory of Silesia. This and the fact that a part of the territory of 
the Opolskie province belongs to the historical territory of Lower Silesia provoked a debate - in both the academic and local/regional politics - whether the Opolskie province should remain on the administrative map of Poland or should be liquidated and divided between the Śląskie province and Dolnośląskie province (Berlińska 1998; Habuda i Habuda 2014; Honka 2014; Lis 1998; Malarski 1998; Simonides 1998; Sokołowski 2014; Zaborowski 2009). Taking into consideration arguments concerning the province's economic and social functionality, in the contemporary debate, the Opolskie province is given as an example of a region that has become a "victim" of the administrative reform as a region whose territory is too small, which is poorly populated and insufficiently urbanized. Simultaneously, from the perspective of regional identity, it is one of a few regions whose inhabitants show strong regional identification, which manifested itself, among other things, in effective lobbying for the maintenance of the province on the administrative map of Poland after the territorial division reform (Geisler 2009).

Referring to arguments of a historical character, it should be noted that in the past Opole was an important center of state and ecclesiastical administration systems, and the region's territory referred to nowadays as Opole Silesia started to take shape in the 19th century after the establishment of the Opole District as an administrative unit of the Prussian state. After World War II Opole Silesia was administratively separated from Upper Silesia (simultaneously with the establishment of the Opolskie province in 1950). The creation of the Opolskie province was also the consequence of the division of the region's inhabitants into two distinctive groups: one in the industrialized part of Upper Silesia, and the other in the agricultural areas of Opole Silesia (Berlińska 1999; Geisler 2009). Moreover, unlike the present Dolnośląskie and Śląskie provinces, the Opolskie province was characterized by a high degree of cultural diversity. After the war it was inhabited by both the autochthonous Silesian population (as an indigenous ethnographic group within the "political" Polish nation), the German or Germanized Silesian population (which in its majority emigrated to Germany in the years 1956-58 and in the 1980s; cf. Korbel 1990; Kamusella 1999), people forcefully displaced from the areas of the Second Republic of Poland, and settlers from different parts of Poland. The migration processes created a new cultural and social situation that was quite different from that in the other parts of the so-called recovered territories of post-war Poland. The arguments presented above proved that the Opolskie province can be defined as a region not only in the sense of administrative division, but also as a culturally distinctive area. 
At present the Opolskie province covers the area of $9412 \mathrm{~km}^{2}$ and is populated by 990,000 people $^{25}$. It is located in the south-western part of Poland. Its southern boundary runs along the state border between Poland and the Czech Republic. It is one of the most permanent administrative borders in Europe ${ }^{26}$. The Opolskie province borders on the Dolnośląskie province to the west, the Śląskie province to the east, as well as the Lódzkie province and the Wielkopolskie province to the north. It is the smallest province in Poland with respect to its area and population. The city of Opole is the seat of the provincial authorities. Besides Opole inhabited by 128,000 people, the most populous towns are Kędzierzyn-Koźle and Nysa with 62,000 and 44,000 inhabitants respectively. The province is divided into 11 districts and one municipal district (Opole) as well as 71 communes ( 3 urban communes, 33 urban-rural communes, and 35 rural communes).

Analyzing the region with respect to minority group, we can divide the province into two parts: the eastern part with a considerable percentage of Germans and Silesians, and the western part, practically without any larger groups representing ethnic minorities. This phenomenon is illustrated in Map. 2.

As it has already been mentioned, in comparison to the other provinces in Poland, the Opolskie province is the smallest and the least populous (see Tab. 6). However, in terms of some life quality indexes, it stands out among the other Polish provinces (see Tab. 7). Despite the relatively low average level of material wealth, the region's inhabitants enjoy some of the highest life conditions and social well-being indexes in Poland ${ }^{27}$.

As regards the data concerning selected governance quality indexes, what draws attention is first of all the lowest percentage of women - councillors of the provincial assembly. It is only $10 \%$, while the average for Poland is $25 \%$. There are more women in commune councils ( $30 \%$ as compared to the national average of $27.5 \%$ ). The level of education of commune councillors ( $40.4 \%$ of councillors with higher education) also places the region above the national average of $36 \%$.

25 https://opole.stat.gov.pl/files/gfx/opole/pl/defaultstronaopisowa/1163/1/1/18w_05.pdf (Accessed 20 March 2019).

26 Its course was established in 1763 under the Treaty of Hubertsburg ending the Third Silesian War (and the Seven Years' War). Although the course of the border did not change with time, the states that it separated did. In the past the territory of the present Opolskie Province was held by Prussia, the German Empire, the Weimar Republic, the Third Reich, and eventually Poland.

27 Social well-being is "the absence of a sense of loneliness; a sense of being loved and respected; having friends” (Czapiński and Panek 2015: 436). 
Tab. 6: The Opolskie province against a background of the other Polish provinces in terms of the basic geographic and demographic data

\begin{tabular}{lllll}
\hline Province & $\begin{array}{l}\text { Area } \\
\left(\mathbf{k m}^{2}\right)\end{array}$ & $\begin{array}{l}\text { Population } \\
(\mathbf{( 0 0 0 )}\end{array}$ & $\begin{array}{l}\text { Urbanization } \\
\text { index } \mathbf{( \% )}\end{array}$ & $\begin{array}{l}\text { Internal and external } \\
\text { migration balance } \\
\text { per 1000 people }\end{array}$ \\
\hline Mazowieckie & 35558 & 5365.9 & 64.3 & 2.4 \\
Wielkopolskie & 29826 & 3481.6 & 54.7 & 0.3 \\
Lubelskie & 25122 & 2133.3 & 46.4 & -1.9 \\
Warmińsko-mazurskie & 24173 & 1436.4 & 59 & -2.1 \\
Zachodniopomorskie & 22892 & 1708.2 & 68.5 & -0.6 \\
Podlaskie & 20187 & 1186.6 & 60.6 & -1.1 \\
Dolnośląskie & 19947 & 2903.7 & 69 & 1 \\
Pomorskie & 18310 & 2315.6 & 64.2 & 1.5 \\
Łódzkie & 18219 & 2485.3 & 62.9 & -0.6 \\
Kujawsko-pomorskie & 17972 & 2083.9 & 59.5 & -0.8 \\
Podkarpackie & 17846 & 2127.7 & 41.2 & -0.8 \\
Małopolskie & 15183 & 3382.3 & 48.4 & 1.1 \\
Lubuskie & 13988 & 1017.4 & 64.9 & -0.8 \\
Śląskie & 12333 & 4559.2 & 77 & -1 \\
Świętokrzyskie & 11711 & 1252.9 & 44.6 & -1.4 \\
Opolskie & $\mathbf{9 4 1 2 ( 1 6 )}$ & $\mathbf{9 9 6 . 1 ( 1 6 )}$ & $\mathbf{5 1 . 9 ( 1 2 )}$ & $\mathbf{- 1 . 4 ( 1 3 )}$ \\
\hline
\end{tabular}

Source: Rocznik Statystyczny Województw, GUS, Warszawa 2017; Społeczeństwo informacyjne w Polsce. Wyniki badań statystycznych $z$ lat 2012-2016, GUS, Warszawa 2016.

The province is one of the regions where the percentage of people using public administration services over the internet is the lowest (see Tab. 8).

\section{The place of the Opolskie province in the European Governance Quality Index}

As a starting point in an analysis of the position of the Opolskie province on the European map of good governance, it is worth taking into account its specific character as it was perceived by the region's elites and inhabitants during the period of fight for the continued existence of the province during the period of preparing the administrative reform of 1998. The research conducted by sociologists from the University of Opole shows that at that time both the elites and ordinary inhabitants created an image of the Opolskie province in 
Tab. 7: Selected life quality indexes for the Opolskie province

\begin{tabular}{|c|c|c|c|}
\hline Index & Value & $\begin{array}{l}\text { Place in } \\
\text { ranking } \\
\text { (1-the best } \\
\text { ranked unit } \\
\text { out of } 16 \\
\text { provinces) } \\
\end{array}$ & $\begin{array}{l}\text { Average value } \\
\text { for Poland }\end{array}$ \\
\hline Ability to communicate in English & $19.8 \%$ & 6 & 19.9 \\
\hline Access to internet & $61.8 \%$ & 10 & 64.8 \\
\hline Average net personal income & 1408.81 zlotys & 10 & 1549 \\
\hline $\begin{array}{l}\text { Percentage of households using external } \\
\text { assistance }\end{array}$ & $12 \%$ & 13 & $9.7 \%$ \\
\hline $\begin{array}{l}\text { Living conditions of households (synthetic } \\
\text { measure) }\end{array}$ & 0.364 & 2 & no data \\
\hline $\begin{array}{l}\text { Percentage of town/city inhabitants very } \\
\text { satisfied or satisfied with their place of living }\end{array}$ & $60.6 \%$ & 5 & $58.4 \%$ \\
\hline $\begin{array}{l}\text { Percentage of people sensitive to damage to } \\
\text { public goods }\end{array}$ & $56.5 \%$ & 5 & $51.9 \%$ \\
\hline Civilization level & -0.08 & 11 & no data \\
\hline Social well-being & 0.16 & 1 & no data \\
\hline Material wealth & -0.16 & 12 & no data \\
\hline Social pathologies & 0.03 & 10 & no data \\
\hline Social capital & 0.00 & 8 & no data \\
\hline Physical well-being & -0.05 & 13 & no data \\
\hline $\begin{array}{l}\text { Percentage of children in crèches (day care } \\
\text { centers)* }\end{array}$ & $12.5 \%$ & 2 & $8.6 \%$ \\
\hline Unemployment rate ${ }^{*}$ & 9.0 & 9 & 8.2 \\
\hline Matura examination success rate & 77.6 & 12 & $78.5 \%$ \\
\hline $\begin{array}{l}\text { Percentage of children aged 3-5 attending } \\
\text { kindergartens* }\end{array}$ & 89.7 & 2 & 84.7 \\
\hline Average gross salary* & 4144.91 zlotys & 7 & 4527.89 \\
\hline
\end{tabular}

Source: the authors' own work based on Diagnoza Społeczna 2015 (Czapiński i Panek 2015) and Local Data Bank $\left(^{*}\right)$. The data from Diagnosis come from 2015, the data from the Local Data Bank - from 2017.

opposition to the Katowickie province, to which the Opole Region was to be joined within the scope of Poland's administrative division into 12 provinces. According to the stereotype developed in that period the Opole Region was perceived as a thrifty and law-abiding region with a road network of good quality, 
Tab. 8: The position of the Opolskie province in comparison to the other provinces with respect to selected governance quality indexes (data for 2016; in \%)

\begin{tabular}{|c|c|c|c|c|c|}
\hline Province & $\begin{array}{l}\text { Percentage } \\
\text { of women } \\
\text { among } \\
\text { commune } \\
\text { councillors }\end{array}$ & $\begin{array}{l}\text { Percentage } \\
\text { of women } \\
\text { in the } \\
\text { provincial } \\
\text { assembly }\end{array}$ & $\begin{array}{l}\text { Percentage } \\
\text { of } \\
\text { councillors } \\
\text { with higher } \\
\text { education }\end{array}$ & $\begin{array}{l}\text { Percentage } \\
\text { of people } \\
\text { using the } \\
\text { internet on } \\
\text { a regular } \\
\text { basis }\end{array}$ & $\begin{array}{l}\text { Percentage of } \\
\text { people using public } \\
\text { administration } \\
\text { services over the } \\
\text { internet in the past } \\
12 \text { months } \\
\end{array}$ \\
\hline $\begin{array}{l}\text { Zachodnio- } \\
\text { pomorskie }\end{array}$ & $1(33.2)$ & $5(30)$ & $2(42.2)$ & $1(76.5)$ & $5(32.5)$ \\
\hline Lubuskie & $2(33.1)$ & $5(30)$ & $5(40.1)$ & $8(69.4)$ & $15(22.9)$ \\
\hline Dolnośląskie & $3(32.3)$ & $8(25)$ & $3(40.4)$ & $7(70)$ & $8(27.1)$ \\
\hline $\begin{array}{l}\text { Warmińsko- } \\
\text { mazurskie }\end{array}$ & $4(32.1)$ & $1(40)$ & $8(37.7)$ & $13(66.9)$ & $14(25)$ \\
\hline Opolskie & $5(29.9)$ & $16(10)$ & $3(40.4)$ & $5(71.5)$ & $11(26)$ \\
\hline Pomorskie & $6(29.7)$ & $11(18.2)$ & $7(38)$ & $3(72.9)$ & $4(32.9)$ \\
\hline $\begin{array}{l}\text { Kujawsko- } \\
\text { pomorskie }\end{array}$ & $7(28.5)$ & $14(15.2)$ & $14(33.1)$ & $12(67.3)$ & $12(25.6)$ \\
\hline Mazowieckie & $7(28.5)$ & $3(37.3)$ & $12(33.4)$ & $2(74.3)$ & $2(36.4)$ \\
\hline Śląskie & $9(28.2)$ & $2(37.8)$ & $1(43.1)$ & $4(71.9)$ & $1(36.7)$ \\
\hline Łódzkie & $10(27.9)$ & $4(30.3)$ & $13(33.2)$ & $14(66.2)$ & $10(26.5)$ \\
\hline Wielkopolskie & $11(26.1)$ & $9(23)$ & $6(38.4)$ & $10(68)$ & $8(27.1)$ \\
\hline Świętokrzyskie & $12(25.7)$ & $15(13.3)$ & $9(36.6)$ & $16(62.4)$ & $16(22.6)$ \\
\hline Małopolskie & $13(24.6)$ & $12(17.9)$ & $11(35.2)$ & $6(70.4)$ & $3(34.8)$ \\
\hline Lubelskie & $14(24.2)$ & $10(21.2)$ & $16(29.1)$ & $15(64.5)$ & $6(28.5)$ \\
\hline Podlaskie & $15(23.8)$ & $13(16.7)$ & $15(30)$ & $11(67.6)$ & $7(27.9)$ \\
\hline Podkarpackie & $16(19.4)$ & $7(27.3)$ & $10(35.6)$ & $9(68.5)$ & $13(25.5)$ \\
\hline
\end{tabular}

Subsequently in every field: the place in the ranking of provinces, in parentheses: the absolute value Source: Rocznik Statystyczny Województw, GUS, Warszawa 2017; Społeczeństwo informacyjne w Polsce. Wyniki badań statystycznych z lat 2012-2016, GUS, Warszawa 2016.

efficient work organization, better looking towns and villages, and a political culture characterized by dialogue and readiness for compromise. The excellent example of the last quality was to be the peaceful coexistence of representatives of various cultures, not only the German one but also that of the former eastern borderlands (Berlińska and Nijakowski 2001: 27-33). This image became an essential component of the ideology of the burgeoning regional movement and an argument for the preservation of the Opolskie province that was presented to the central authorities in the form of various expert opinions and reports 
(ibidem: 46). However, as Borys Cymbrowski notes, despite attempts to build a positive image of the multicultural and harmonious Opole Region, the end of the 1990s marked the beginning of a visible fight between the German minority and the Polish majority in the field of collective memory. The fight involved conflicts about monuments of German soldiers and former German names of towns and villages (especially those given in the years 1935-1936) being reinstated by particular communities. These issues caused strong divisions in the regional community of the province (Cymbrowski 2006; see also Kosmala 2005). Thus, in the opinion of regional elites, the Opolskie province - at least at the end of the 20th century - was a modern region characterized by a high level of political, labor, and civic culture and a positive implementation of a policy of multiculturalism.

The regional stereotype was based to some extent on reality, which can be proved by a regularly conducted research on the quality of governance in regions. The research is prepared and conducted by scholars from the Quality of Government Institute in Gothenburg, Sweden. An assessment of the quality of governance in particular regions is based on telephone interviews conducted with their inhabitants in their native languages. Thus, the resultant index is based on citizens' perception. Respondents are asked to give their opinions on the functioning of the public administration system (education, health care, and justice) with respect to the following three dimensions of the quality of governance: service quality, impartiality, and corruption (Charron, Dijkstra \& Lapuente 2012: 5). So far the research has been carried out three times. Consequently, we have access to data for the province from different periods. In 2010 and 2013 the Opolskie province scored the most points among the 16 provinces, and in the latest edition of the research in 2017 it was in the second place, behind the Pomorskie province (see tab. 9).

A detailed picture of the places of the Opolskie province in the ranking for the year 2017 is available on the website of the European Commission. It presents assessments of particular regions with respect to the following three dimensions of the quality of governance: the quality of provided services, impartiality, and corruption. With the average score of 42.88 (on a 0-100 scale), the Opolskie province received the most points in the category of the impartiality of the functioning of the public administration system $(54.8)^{28}$. Additionally, the region was compared to 15 other European regions (out of 202 participating in the ranking)

28 See Scorecards - Interactive Tool:https://ec.europa.eu/regional_policy/en/information/ maps/quality_of_governance $\# 2$. 
Tab. 9: The scores of the Polish regions achieved in the European Governance Quality Index in the successive editions of the research (the scale from 0 to 100 , where 0 indicates the lowest quality, and 100 - the highest quality)

\begin{tabular}{llll}
\hline Province & $\mathbf{2 0 1 0}$ & $\mathbf{2 0 1 3}$ & $\mathbf{2 0 1 7}$ \\
\hline Opolskie & $\mathbf{4 7 . 0 8}$ & $\mathbf{4 7 . 0 4}$ & $\mathbf{4 2 . 8 8}$ \\
Warmińsko-mazurskie & 45.98 & 42.46 & 41.88 \\
Świętokrzyskie & 43.40 & 38.23 & 38.22 \\
Łódzkie & 42.61 & 37.30 & 34.97 \\
Podkarpackie & 42.43 & 36.94 & 35.71 \\
Pomorskie & 42.36 & 43.84 & 46.46 \\
Zachodniopomorskie & 41.97 & 41.67 & 41.36 \\
Małopolskie & 41.85 & 41.24 & 40.59 \\
Lubelskie & 41.47 & 39.04 & 35.60 \\
Lubuskie & 40.93 & 43.69 & 40.42 \\
Kujawsko-pomorskie & 40.53 & 46.33 & 41.99 \\
Podlaskie & 40.42 & 44.31 & 39.44 \\
Mazowieckie & 39.66 & 36.48 & 37.98 \\
Wielkopolskie & 39.55 & 39.42 & 39.26 \\
Dolnośląskie & 37.35 & 34.47 & 38.85 \\
Śląskie & 37.28 & 34.52 & 38.89 \\
\hline
\end{tabular}

Source: Charron, Dijkstra \& Lapuente (2010; 2013; 2017).

with similar GDP per capita. The conclusion was that the assessment of the quality of governance in the Opolskie province was higher than those in other regions with a similar level of wealth. It means that the assessment of the quality of governance in the Opolskie province may be influenced by some additional factors, not necessarily ones related to the economic position of its inhabitants.

\section{The Opolskie province's history of multiculturalism}

The greater part of the present Opolskie province belongs to the historic area of Upper Silesia. Opole Silesia started to emerge as a separate subregion in the 20th century. Therefore, it is from the perspective of the region's history that the multiculturalism of the Opolskie province should be perceived. One of the fundamental elements of research on the history of Upper Silesia is the conviction of its frontier character (Bialasiewicz 2002; Kisielewicz 2015; Kwiatek 2015; Trzcielińska-Polus and Opioła 2013). The frontierness of Upper Silesia 
comprises the legacy of the multi-ethnic settlement structure, the blending of the Polish, German and Czech cultures, as well as changes in the political and national affinities - from the Czech and Polish ones, through the Prussian and Austrian ones, to the Czechoslovakian, German and Polish ones.

However, in the case of research on national or ethnic identities in the longterm perspective, a basic methodological error consists in applying - to long periods of time and on the basis of various statistical data and historical sources - the same analytical categories and interpreting such data and sources ahistorically. In the case of the territory of the Opolskie province, which has been a border region for centuries, it is unjustified to apply the category of nationality in its modern meaning to data coming from the 19th century or maybe even from the period up to World War II (cf. Kokot 1973). The development of nations and nationalism as a sense of an "imagined community" (Anderson 1997) as well as the building of identification with such a community are processes that accelerated considerably in the 18th and 19th centuries. At the beginning they comprised elites, but simultaneously with the development of the press, the elimination of illiteracy, and the increasing access to high culture, they were influencing more and more groups of the population (Szacki 1997; Gelner 2009). In border areas where living next door to people speaking different languages or representing different faiths or denominations was a natural part of the local culture, national consciousness understood as a sense of being different from one's neighbor was developing the latest. National ideologies (the dominant German one, the Polish one, and the least dynamic Silesian one) appeared in the Opole Region as late as the second half of the 19th century. Interestingly, they were three projects competing simultaneously for the support of the local population. In many ethnographic and sociological studies conducted in the 20th century, the national - Polish or German - identity of the inhabitants of Silesia appears to be secondary to the regional identity expressed in the sense of "localness", being a Silesian, "being a Silesian more than a Pole", "being a Silesian more than a German", etc., depending on the categories used by researchers (cf. e.g. Berlińska 1999; Kurczewski 2007). Actually, in various research Silesia and Silesians were analyzed as a disadvantaged social group, a peripheral culture, or an internal colony exploited economically by successive jurisdictions and treated as a territory to conquer and subdue, also culturally (Szmeja 2000; Geisler 2015). Piotr Madajczyk, who studied both the actions of the Third Reich authorities towards Poles and the actions of the Polish authorities towards Germans in Opole Silesia after World War II, observed that they had 

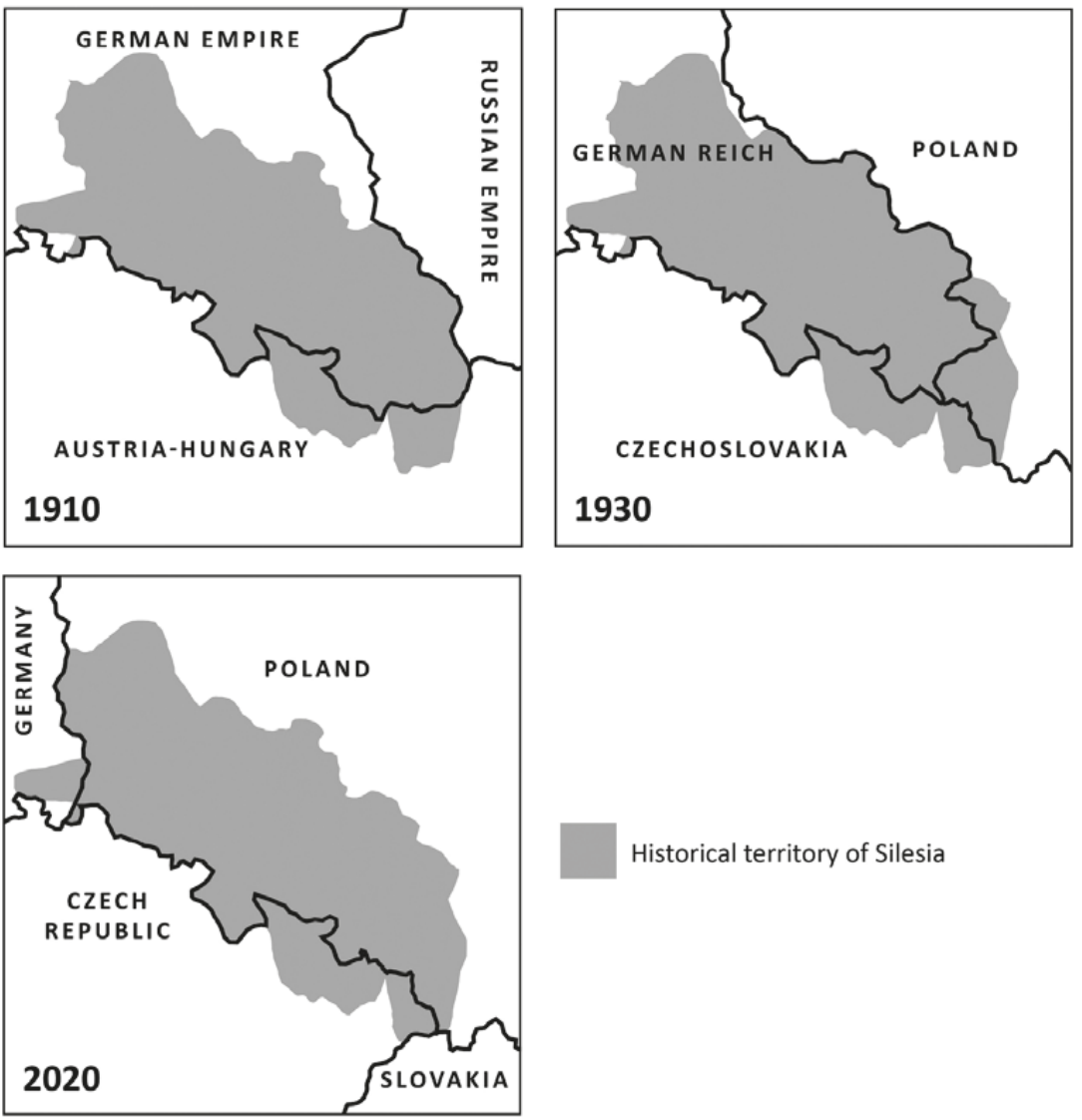

Historical territory of Silesia

Map 3. Border changes in Silesia. Source: the authors' own work

been conducted in accordance with the same pattern. The first step was to displace the clergy and elites representing the other national option; this was followed by the replacement of prayer books, the prohibition against church services in a particular language, and the change of geographical names, personal names and surnames (Madajczyk 1996).

This observation leads to the first conclusion according to which, with respect to the pre-war history of Opole Silesia, Polishness, Silesianness, and Germanness should be interpreted as ethnic identities (whether Silesians are an ethnic or national group - cf. Nijakowski 2004). In many districts the majority 
of inhabitants were ethnic Poles the majority of whom, however, did not develop Polish national identity. Upper Silesia, including the Opole Region, is perceived in historical research as an area inhabited from the Middle Ages by the population speaking the Polish language. As a historical region, it remained successively under the jurisdiction of the Piast dynasty, the Czech crown, and Prussia. However, until the end of the 17th century the ethnic identification of the population had not constituted a "political problem". The first organized assimilation project was the Prussian policy of Germanization launched in the middle of the 18th century during the reign of Friedrich II. Despite this policy, Prussian population registers from before World War I show that the area of Opole Silesia was dominated by the Polish speaking population. Looking for evidence for the historical Polishness of the region after World War II, Polish historians and political scientists quoted, among other things, Prussian statistics concerning the languages spoken at home or used in church services (e.g. Kokot 1973).

Nevertheless, the state of affairs looks different in the context of political science. In the 19th century, economically, culturally and socially disadvantaged, Polish speaking inhabitants of Upper Silesia could choose among the three competing national ideologies: German, Polish and Silesian. Germanization was an element of Prussia's repressive policy of unification. The Polish national ideology was a reaction to that policy (Berlińska 1998). At the end of the 19th century, in parallel to the aforementioned processes, Silesian separatism started to develop on the basis of the sense of Silesian - national or regional - identity (Madajczyk 2005). After Nazis came to power until the end of World War II Upper Silesia was the place of a policy of national assimilation and repressions against culturally different people.

Visible in the current ethnic geography of the province (see Fig. 1), its clear division into the part inhabited by Germans and Silesians is the result of the aforementioned history of the settlement of the Polish and German speaking populations in Silesia before World War II. The area constituting at present the western part of the province was inhabited primarily by the German speaking population, and the Polish speaking minority underwent Germanization during the course of the 18th and 19th centuries. After World War II the inhabitants of these communes - regarded as Germans - were forcefully relocated to Germany. Their households were taken over by Poles relocated to the newly acquired western territories. Meanwhile, before the war the central and eastern parts of the province had been dominated by the Polish speaking population, which to a rather limited degree surrendered to the impact of Germany's national ideology. The majority of this population was not relocated, and the inflow of new settlers 
to these communes was smaller. It was from this particular group of autochthonous Silesian inhabitants of the region that the German minority would develop after 1989.

The process of post-war migrations: the voluntary and forced relocation of citizens of pre-war Germany who did not want or were not able to prove their Polish roots and the settlement of Opole Silesia with the incoming ethnically Polish population was a long-lasting process and - contrary to the prevailing belief - lasted in fact until the 1980s. Its first stage was the mass and forced relocation of the German population conducted in the years 1945-1950. During the same period the Polish population was being forcefully relocated from the territories of prewar Poland which, in consequence of the post-war changes of national borders, became a part of the Soviet Union. Besides relocated people, Opole Silesia became a destination also for settlers from so-called central Poland who, in fact, came from practically all rural areas of Poland suffering from overpopulation and poverty.

The second stage was the so-called family reunification campaign, i.e. a programme of organized migration of pre-war German citizens to Germany under the agreement entered into between the People's Republic of Poland and the German Democratic Republic. The programme was carried out in the years 1950-1952, and subsequently after 1956. In the years 1956-1970 193,000 people emigrated from Upper Silesia to Germany. The emigration process lasted until the end of the 1980s. In total, between 1956 and 1985 more than 400,000 Germans left Upper Silesia (Korbel 1990; Rauziński 1982).

It should be noted that the ethnic structure of the Opolskie province was also under the influence of other factors. Between the years 1950 and 1973 the average population growth rate in the districts with the majority of the autochthonous population was much lower than in the districts dominated by the incoming population. The main reason for this phenomenon was the demographic structure determined by the war, including the gender ratio (much more disadvantageous among the native population) and the age structure (Grodecka 1980). The result was a gradual reversal in the proportion of the number of settlers from the territories of pre-war Poland and people relocated from the eastern borderlands plus their descendants to the number of autochthonous inhabitants plus their descendants; in the 1980s and 1990s it was 2:1. Furthermore, it should be remembered that marriages between the native population and the incoming population were not rare occurrences as early as the 1950s. In the years 19501964 such marriages constituted $6.75 \%$ of the total number of marriages. This rate continued to grow in the subsequent years (Kwaśniewski 1968). 
During the whole era of the People's Republic of Poland and the first years of the Third Polish Republic official statistics and academic research did not refer to the German or Silesian ethnic identification of the inhabitants of Opole Silesia. Just the opposite, authorities and researchers emphasized their unequivocal Polish national orientation (e.g. referring to them as "native Poles", as opposed to Poles coming from other parts of the country; cf. e.g. Kowalski 1972; Jacher 1991). The disclosure of complicated national identities took place in connection with the by-election for a vacant seat in the Senate in 1990 (i.e. in parallel to the processes of democratization and pluralization) when a candidate representing the German minority was running for the first time for such a high office, and the establishment of the Social and Cultural Association of Germans in Opole Silesia in Stradunia, near Krapkowice on 7 April 1990 (Berlińska 1999). It was at that time that researchers noticed and started to study the heterogeneity of the national consciousness of the province's inhabitants. According to Bogdan Cimała and Stanisław Senft (1994), the population that after the war decided to remain in Poland and acquire Polish citizenship can be divided into three groups. The first of them comprises members of the Association of Poles in Germany, who probably represented the strongest sense of Polishness. This group, however, constituted only a few percent of the total autochthonous population. The second group includes people who maintained connections with Polish culture, i.e. read the Polish press, participated in events organized by the Association of Poles in Germany. The historians mentioned above estimate that this group constituted $1 / 3$ of the total autochthonous population. The decisive majority of the native population were people referred to by Germans as labile Zwischenschicht, and who referred to themselves as Upper Silesians or Silesians (Cimała and Senft 1994). In this group, it is possible to distinguish many variants of attitudes ranging from indifference through a sense of regional identity to a double or ambivalent identity. These communities were rather poorly susceptible to either German or Polish nationalistic campaigns conducted during the Silesian uprisings and later during the two decades between the World Wars. Naturally, their contacts with German culture were more frequent and stronger than with Polish culture as they were citizens of the Weimar Republic and subsequently the Third Reich.

Another factor used to explain the appearance of people of German origin after 1989 was economic motivations for adopting a national identification. A declaration of German nationality made it possible to acquire a German passport and, consequently, the right to work in Germany, which was connected with 
economic and social advancement. Another reason for changes in the national self-identification of the inhabitants of the Opolskie province was the ineffectiveness of the policy of Polonization pursued by the Polish authorities during the period of Stalinism. A number of factors caused a loss of Silesians' trust in Poland and Polishness embodied in the unfriendly local bureaucratic machine (schools, commune offices). They included hostility of the incoming population against the autochthonous population, discrimination against and persecution of many pre-war activists of the Association of Poles in Germany, filling administrative positions with representatives of the incoming population, or everyday discrimination of the local population because of its origin, as well as linguistic and cultural differences. The Polish United Workers' Party admitted having pursued its ineffective policy aimed at the native population of the areas incorporated into Poland after World War II in a resolution of its Central Committee adopted in 1960 (Strauchold 2005). This problem concerned not only Silesians but also Mazurians; the inclusion of these groups in the Polish nation was "an argument legitimizing the change of the western border" (Madajczyk and Berlińska 2008: 240).

The uniqueness of the ethnic geography of the Opolskie province against the background of Poland is reflected in regional and local politics. The German minority is well organized and politically empowered in the part of the province inhabited by Germans and Silesians; it is the key grouping in the provincial assembly as well as many commune and district councils (Fig. 2; see also Ganowicz and Opioła 2017). Furthermore, the only representative of national minorities sitting in the parliament is Ryszard Galla, representing the electoral committee of the German minority in the Opolskie electoral area and holding the seat constantly since 2005 . Through its organizational representation - the Social and Cultural Association of Germans in Opole Silesia - the German minority is also an actor of Polish-German public diplomacy, aiming to strengthen economic, social and cultural relations between the Opolskie province and Germany. A similar, though less comprehensive role is fulfilled by the Diocese of Opole and Caritas of the Diocese of Opole (Bartek 2015). The multiculturalism of the region is also reflected in regional strategic documents, although it appears that its potential is not fully utilized. In The Development Strategy of the Opolskie province until 2020, an extensive description of the region's multicultural character appears in the diagnostic part:

Nowadays the Opolskie province is inhabited in harmony by Silesians, Germans and the immigrant population of diversified regional origins, including people relocated from the Eastern Borderlands of the Second Republic of Poland [Borderlanders]. This 
historically shaped multiculturalism of the Opolskie province, particularly the presence and initiative of the largest group of the German minority in Poland, constitutes a distinctive feature of the present image of the region and its significant characteristic against the background of the whole country ('Strategia' 2012: 28).

Although the SWOT analysis included in the strategy identifies cultural diversity as one of the strengths of the region, the potential offered by multiculturalism has not been utilized sufficiently enough at the level of objectives. Among 36 operational objectives formulated in the strategy, only one refers directly to multiculturalism.

\section{The present state of multiculturalism in Opole Silesia}

In view of the analyses presented above, it should be stated that at present the region's multiculturalism is shaped first of all by people of Polish, German and Silesian national identities. Regardless of these three nationalities, it is possible and even advisable - to distinguish separate Polish ethnographic groups that are the outcome of post-war migrations and the blending of representatives of various ethnographic groups in the territories constituting settlement destinations (Masurians, natives of Greater Poland, Lesser Poland or the region of Lviv and Tarnopil). For these reasons, after the war the Opolskie province was the area where inhabitants with an integral national identity constituted a decisive minority. Following Antonina Kłoskowska (1996), who postulates that research on nationality should take into equal consideration the indicators of national identity and of cultural valence (cultural valence understood as adopting a given national culture and treating it as one's own), it is possible to distinguish the following dominant categories of the province's inhabitants:

a) inhabitants manifesting an integral national identification (e.g. "I am Silesian") and a cultural bivalence (the adopted German and Polish cultures);

b) inhabitants manifesting an integral national identification ("I am either Polish or German") and a cultural bivalence ("more often Polish and Silesian"; "less often German and Silesian");

c) inhabitants manifesting a double national identification ("I am Silesian and Polish"; "I am German and Polish") and a cultural bivalence or ambivalence;

Nevertheless, the process of post-war relocations resulted in the strengthening and, consequently, the present domination of the fourth category: 


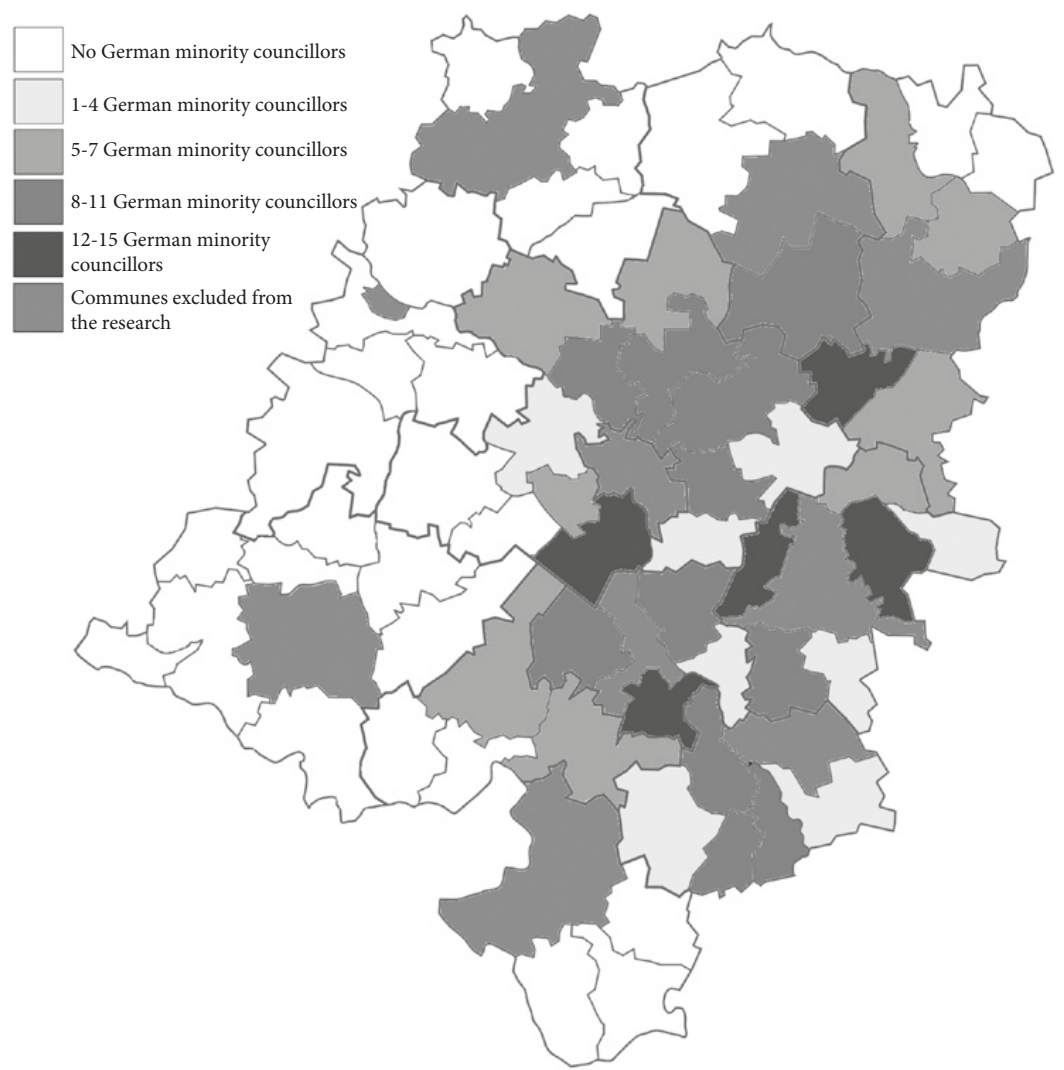

Fig. 3: The number of councillors representing the German minority in the commune councils of the Opolskie province during the term of office 2014-2018 ${ }^{29}$. Source: the authors' own work based on the data from the National Electoral Commission

d) inhabitants manifesting an integral national identification ("I am Polish") and a cultural univalence (the adopted Polish culture).

The recent years have witnessed a dynamic increase in the number of people coming from Ukraine to the territory of the Opolskie province. This process is typical of the whole territory of Poland: according to estimates, approximately

29 All communes included in the research have councils consisting of 15 members (with the exception of the commune of Głuchołazy, which has 21 councillors). 
2 million Ukrainians study, work and live in Poland. The Ukrainian population was not included in the latest census because the mass process of settlement immigration from Ukraine is a relatively new phenomenon. The outbreak of the war in Donbas in 2014 can be regarded as an event that accelerated this process. According to the data of the National Insurance Institution, in 2018 the number of Ukrainians in legal employment in the Opolskie province exceeded 14500 (Hanszke 2018). Meanwhile, according to the Provincial Labour Office, there were 64000 Ukrainians working legally in the Opolskie province in 2018 (Dimitrow 2019). In view of the fact that the number of Germans living in the province equaled 78000 in 2011 (according to the national census), the scale of migration from Ukraine strongly influences the academic discourse on the region's multiculturalism. In the case of our research, the influence of the presence of Ukrainians in the province on research results is ignored for two reasons. Firstly, the decisive majority of them have the status of foreigners, thus, naturally, they have no influence on many areas related to the quality of governance. Secondly, they live mostly in the largest urban centers, which are excluded from our research.

Summing up, let us present the ethnic structure of the Opolskie province. At the provincial level, the latest data come from the national census carried out in 2011. According to these data, the Opolskie province was inhabited by 895,000 people declaring Polish nationality ${ }^{30}, 106,000$ people declaring Silesian nationality, and 78,000 declaring German nationality. Furthermore, the census failed to establish the identity of over 22,000 people. Also, the number of people of Romany nationality was established at around 200 (according to the estimates of the Provincial Office, there are between 1500 and 2000 Romanies in the province), and 2700 people declared nationality other than Polish, Silesian, German or Romany. In comparison to the data of the 2011 national census, because of demographic processes (migrations, population growth), the respective sizes of the Polish, Silesian, and German populations have decreased, and a group of foreigners of Ukrainian nationality has appeared. Its size is estimated at about 70,000 people. The total population of the province (including foreigners) amounts to over 1 million people.

30 In the case of persons declaring a double identification, they were classified as being of the first declared national identification. 



\section{Quantitative analysis: the results of measurements and their interpretation}

The quantitative analysis comprised 60 communes of the Opolskie province: 25 urban-rural ones and 35 rural ones. The communes constituting towns being simultaneously the seats of district authorities, i.e. the communes of Opole, Brzeg, Głubczyce Kędzierzyn-Koźle, Kluczbork, Krapkowice, Namysłów, Nysa, Olesno, Prudnik, Strzelce Opolskie, were excluded from the analysis because of the possible influence of other variables on research results. The selected information on the demographic, economic and political situation of the communes under examination is presented in Tab. 10. Since we assume that the quality of governance can be also influenced by other factors such as the size or urbanization level of a commune, at the stage of the statistical analysis we examined the hypothetical potential of the dependence of the quality of governance as related to several independent variables and calculated partial correlations between the ethnic fractionalization index and the quality of governance, taking into consideration the influence of other factors. Because a statistical analysis was not an aim in itself, but rather a method making it possible to observe relationships and to select a few cases for a further qualitative analysis, we decide to apply such measures as correlation and scatter plot analysis. In some cases we made additional use of such measures as coefficient of determination and partial correlation.

The research sample is dominated by the communes inhabited by from 5000 to 10000 people. The most populous is the commune of Głuchołazy - 26447 people; the commune of Świerczów has the fewest inhabitants - 3710. Głuchołazy is also the largest among the towns included in the research (13,700 inhabitants). Because of a large disproportion between the commune of Głuchołazy and the other communes, the decision was made not to include it in the qualitative analysis, irrespective of the result of governance quality measurement.

\section{General characteristics of selected communes}

With a few exceptions, the selected communes are characterized by a low level of industrialization, which is indirectly indicated by the percentage of people in employment (exclusive of agriculture and enterprises employing up to 9 persons) $)^{31}$. The commune of Skarbimierz can be regarded as industrialized (the

31 The used indicator is the percentage of people in employment, monitored on a regular basis by the Central Statistical Office. It should be understood as the ratio of people in 
percentage of people in employment: $37.9 \%)$. With respect to political participation at the local level, what deserves attention is the higher percentage of electoral areas with one candidate per one seat in a council in the multi-ethnic communes. These relationships will be analyzed in detail in the further part of this chapter.

\section{Results of the governance quality measurement}

Tab. 11 presents the values of the governance quality index. The manners in which the measures are developed and data are obtained are described in Chapter 2. Detailed information on each of the 25 indexes is included in the attachment to the book. At this point we would only like to present a few pieces of information concerning the quantification of the quality of governance. Each of the 25 indexes was transformed to a $0-1$ scale. In this way, the governance quality index was included in a scale from 0 to 25 , and each of its sub-indexes (participation, equality, effectiveness, accountability, openness) in a scale from 0 to 5 . In practice, it was impossible to score 25 points because each index was scaled to an "ideal" value, i.e. a value for which " 1 " indicates a desired state from the point of view of the idea of good governance.

The average value of the governance quality index for all 60 communes covered by the research was 11.09 . The values of the particular sub-indexes equaled, respectively:

- the participation sub-index: 2.69;

- the equality sub-index: 1.87 ;

- the efficiency sub-index: 1.87;

- the accountability sub-index: 1.85 ;

- the openness sub-index: 2.82 .

The geographic distribution of the communes in accordance with the governance quality index is presented in Fig. 4. A geographic analysis does not reveal any particular "pattern". What draws attention is that the majority of the communes with the more than average GQI index (the colors red and brown) are located in the central and eastern parts of the province. Simultaneously, the communes

employment to the total population, with the exception of people working in agriculture and employed in micro-enterprises with up to 9 employees. This indicator provides indirect information on the percentage of people employed in industrial enterprises: in small communes the majority of entities employing more than 9 persons are public institutions and industrial enterprises. 


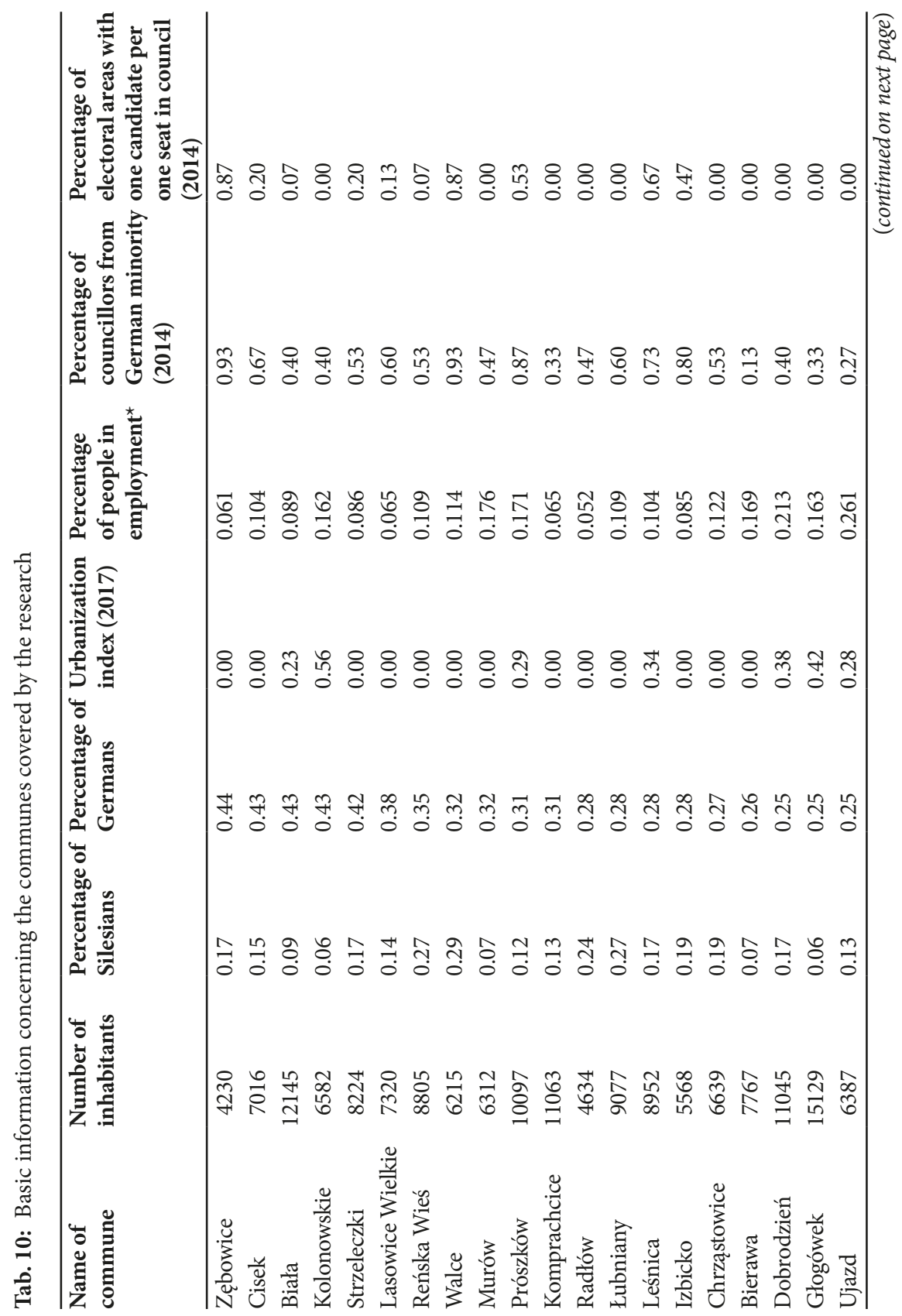




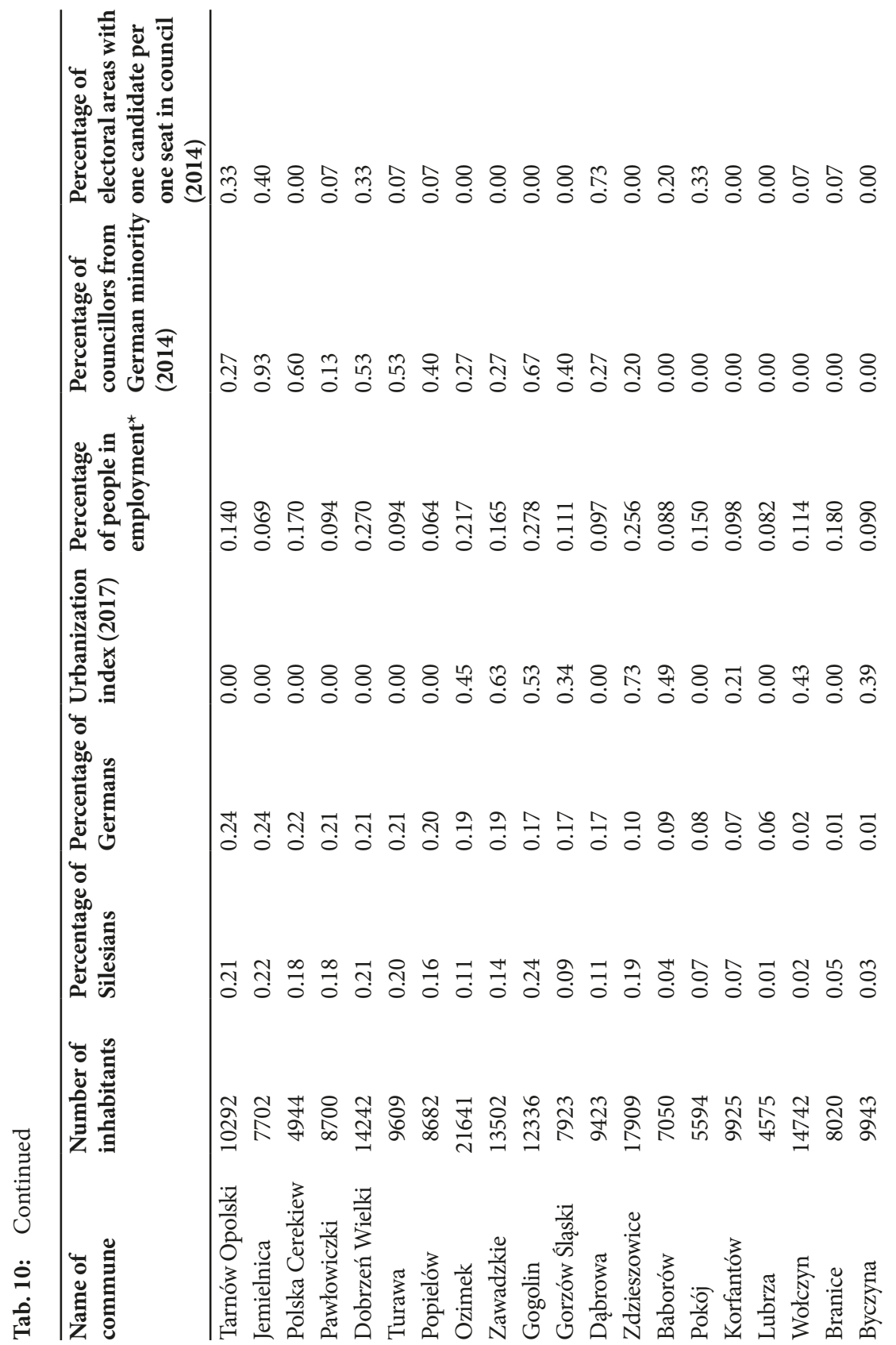




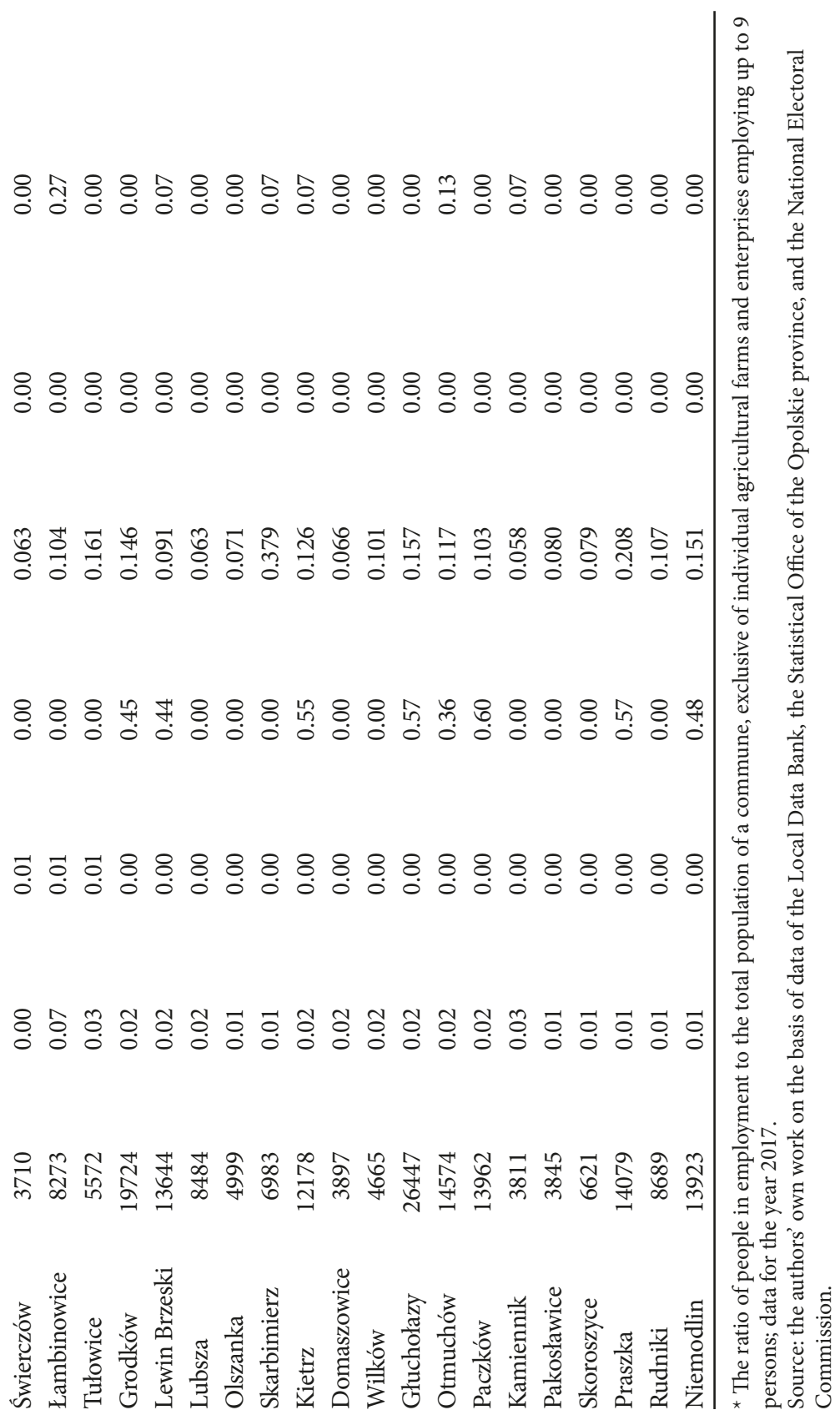




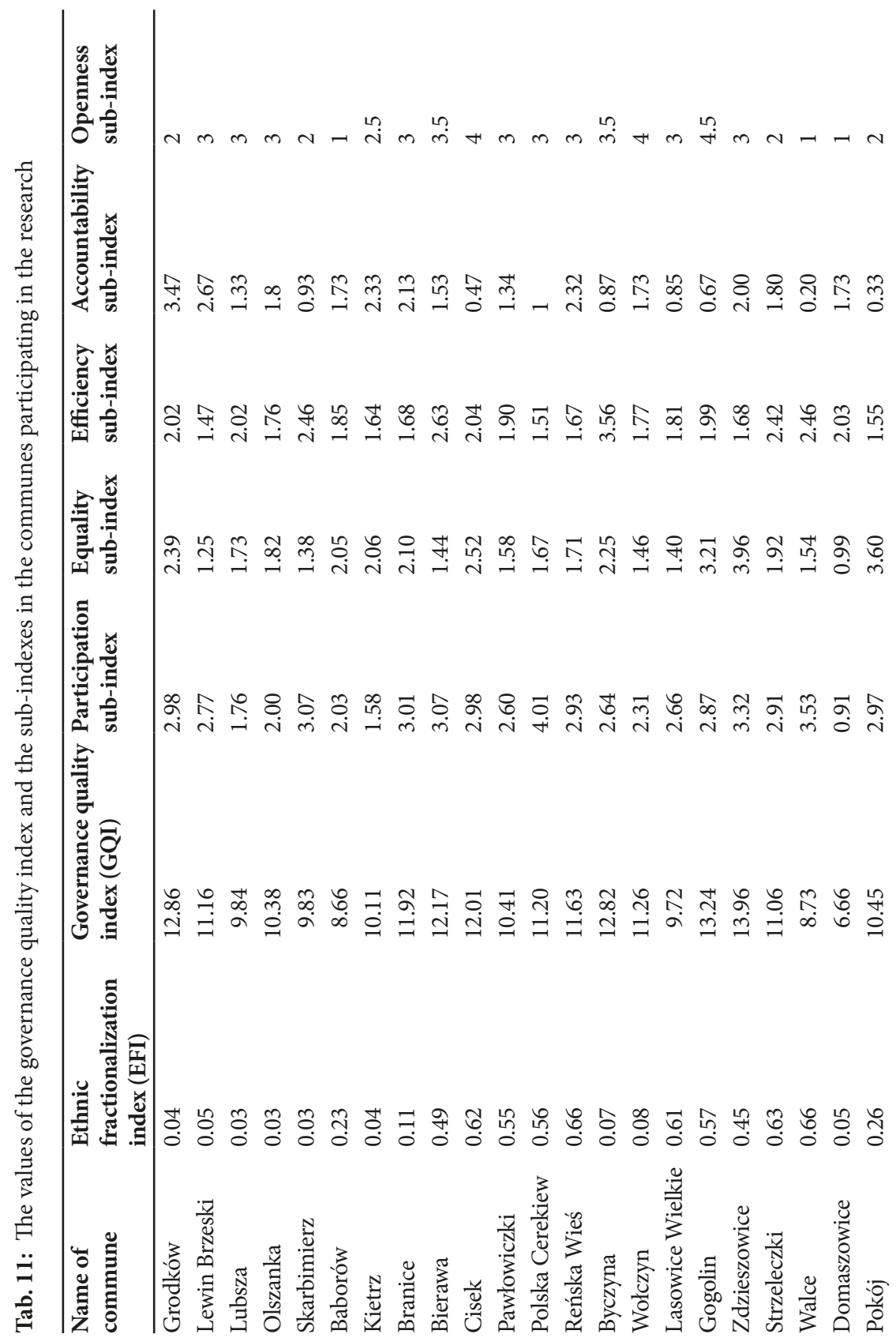




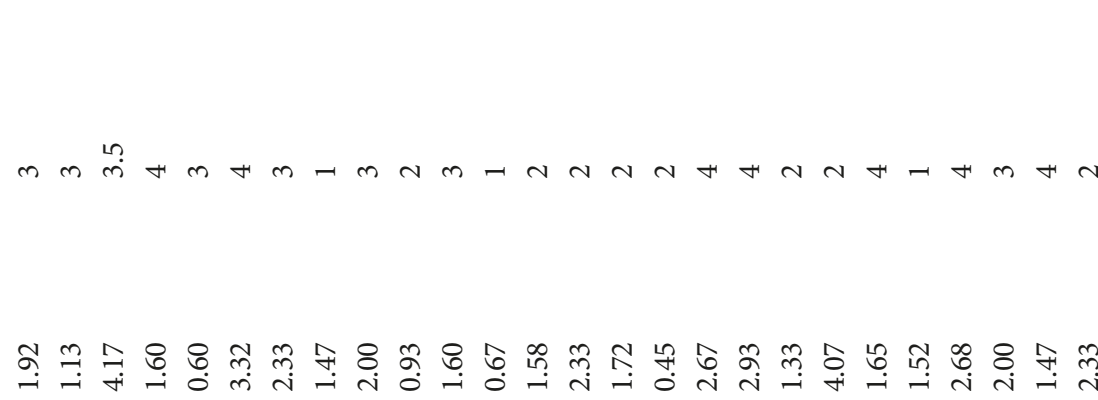

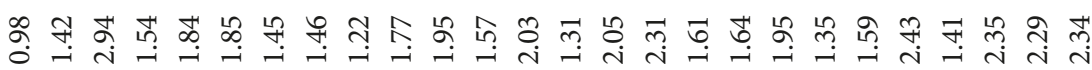

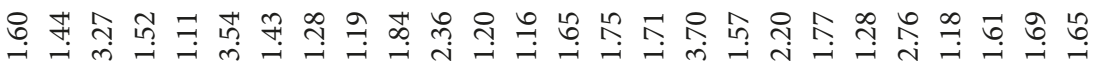

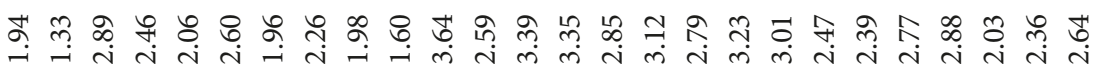

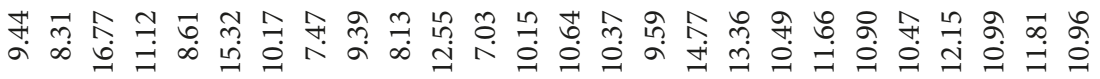

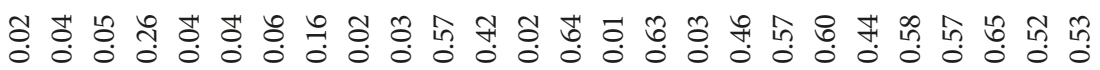

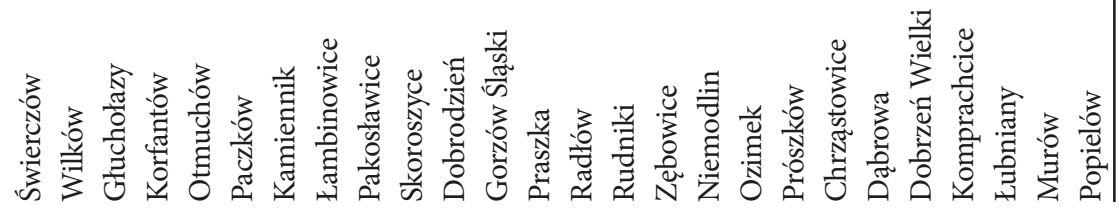




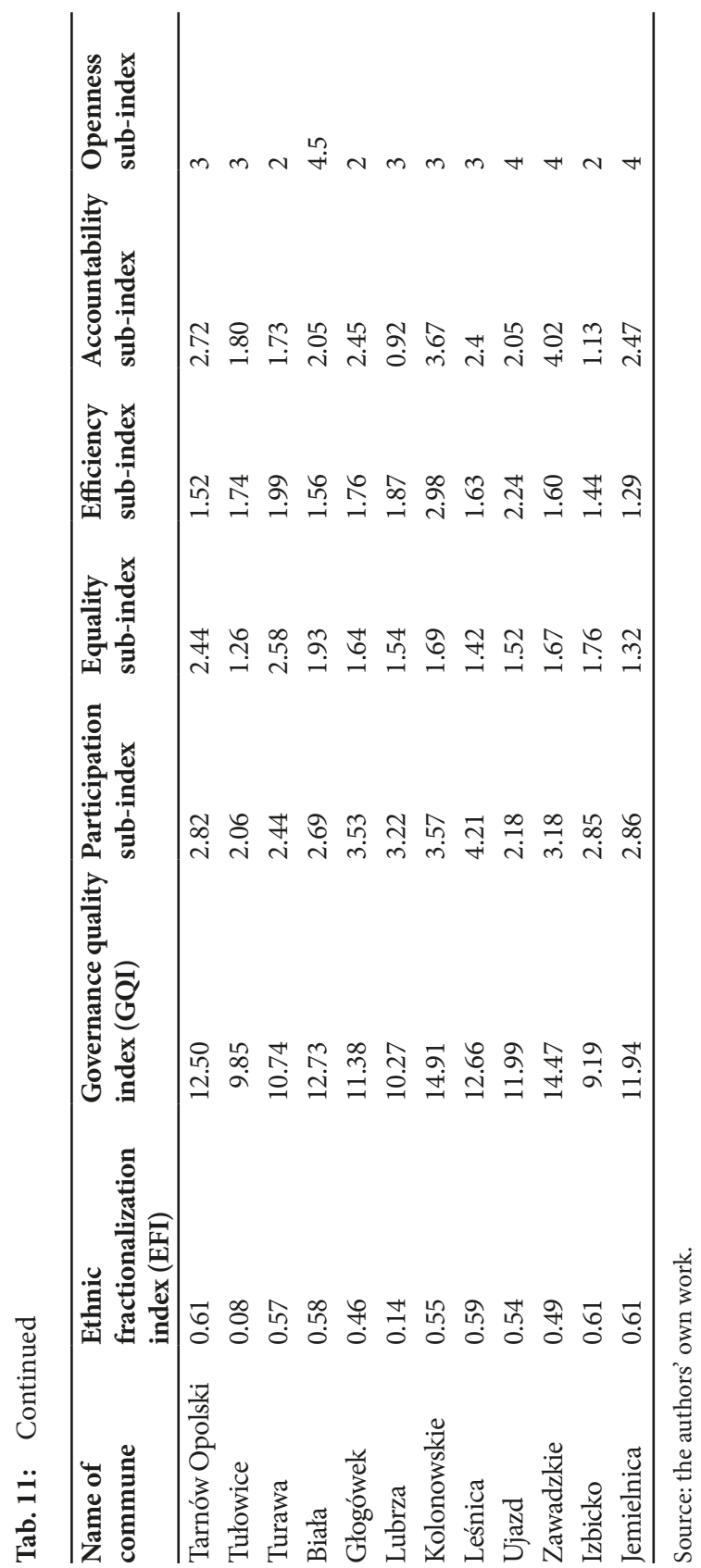




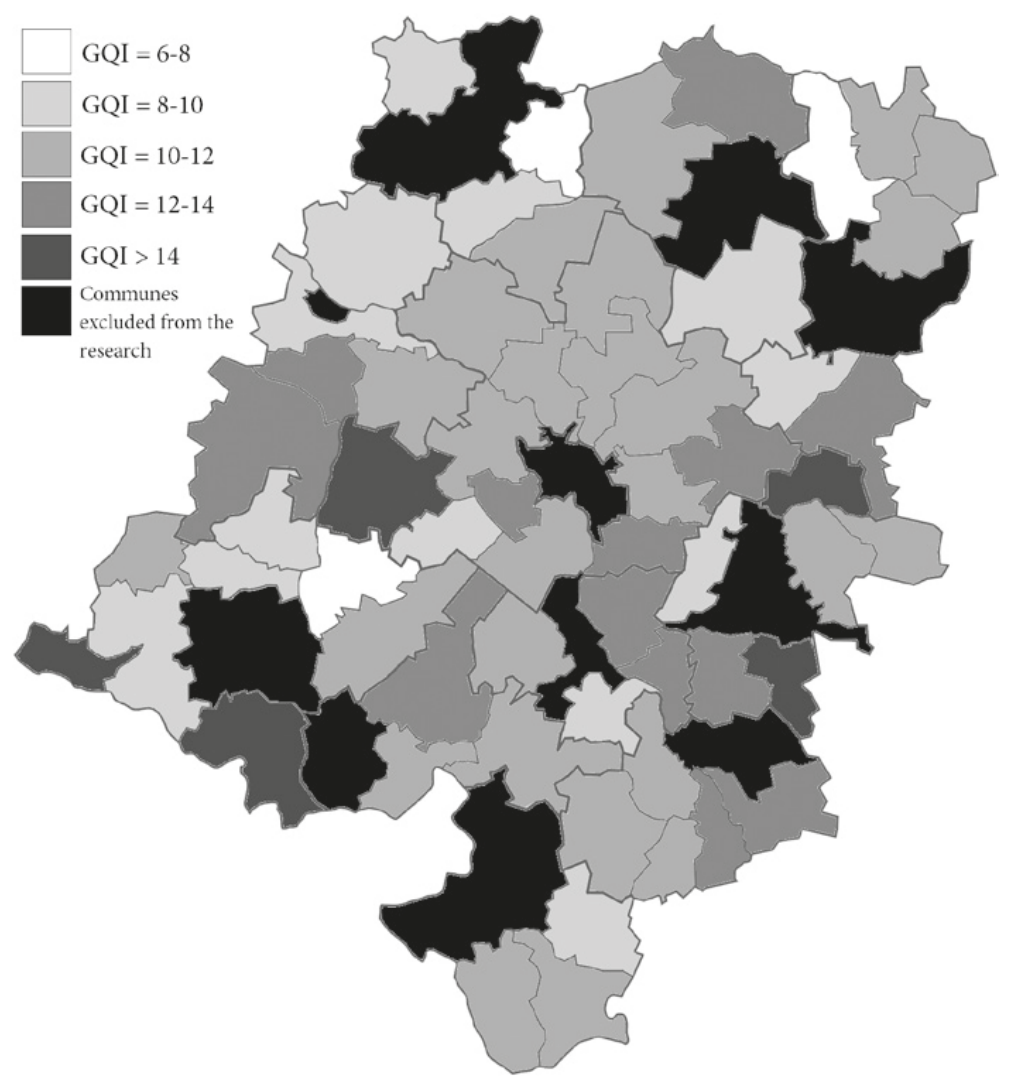

Fig. 4: The governance quality index in the communes of the Opolskie province. Source: the authors' own work

with the highest GQI index are located in the south-western part of the province. The common feature is that the five communes with the highest GQI index are urban-rural communes. Among the five communes with the lowest values of the index, only one is an urban-rural commune. No impact of the sub-regional level (district) on the quality of governance was observed. In only one district (the Namysłowski district), all communes had similar values of the index (all of them below the average for the whole province). In the other districts, considerable differences among particular communes could be observed. The conurbation effect does not influence the quality of governance, either: the communes around the city of Opole are characterized by the level of governance close to the average for the whole province. 


\section{Correlation analysis}

Tab. 12 presents the values of the correlations under examination. As far as the interdependence between ethnic diversity and government quality is concerned, these variables poorly correlated with each other (the correlation is statistically insignificant, and the coefficient of determination equals 0.03). Fig. 5 present a scatter plot for these variables. Testing the other independent variables, we observed a statistically significant relationship between the number of inhabitants in a commune (0.589) plus the urbanization index (0.531) and the quality of governance. These relationships are shown in Figures 6-7. There occurs a poor, but statistically significant interdependence between the percentage of people in employment and the quality of governance.

Summing up, we did not identify a simple relationship between ethnic diversity and the quality of governance. Thus, the hypothesis put forward at the beginning of the book was proven wrong. The quality of governance at the communal level is strongly influenced by the other variables which despite the formulated preliminary assumptions (e.g. the exclusion of district towns in order to eliminate the impact of the size of a commune) influenced our sample. For the purpose of an additional verification, we calculated partial correlations between ethnic diversity and governance quality, taking into consideration the impact of the other tested independent variables (see Tab. 13). Taking into account the level of urbanization, we notice a significant correlation between ethnic diversity and governance quality. Thus, our hypothesis may be true exclusively for the rural communes, i.e. in the ethnically diversified rural communes, the quality

Tab. 12: The correlations between the selected variables $(n=60)$

\begin{tabular}{lllllll}
\hline & $\begin{array}{l}\text { Governance } \\
\text { quality index }\end{array}$ & $\begin{array}{l}\text { Participation } \\
\text { sub-index }\end{array}$ & $\begin{array}{l}\text { Equality } \\
\text { sub-index }\end{array}$ & $\begin{array}{l}\text { Efficiency } \\
\text { sub-index }\end{array}$ & $\begin{array}{l}\text { Accountability } \\
\text { sub-index }\end{array}$ & $\begin{array}{l}\text { Openness } \\
\text { sub-index }\end{array}$ \\
\hline $\begin{array}{l}\text { Ethnic } \\
\text { fractionalization }\end{array}$ & 0.180 & 0.488 & 0.013 & 0.056 & -0.029 & 0.043 \\
$\begin{array}{l}\text { index (EFI) } \\
\begin{array}{l}\text { Number of } \\
\text { inhabitants }\end{array}\end{array}$ & 0.589 & 0.246 & 0.416 & 0.179 & 0.456 & 0.240 \\
$\begin{array}{l}\text { Urbanization } \\
\text { index }\end{array}$ & 0.531 & 0.237 & 0.382 & 0.153 & 0.391 & 0.225 \\
$\begin{array}{l}\text { Percentage } \\
\text { of people in } \\
\text { employment }\end{array}$ & 0.315 & 0.340 & 0.310 & 0.272 & 0.008 & 0.071 \\
\hline
\end{tabular}

Source: the authors' own work. 


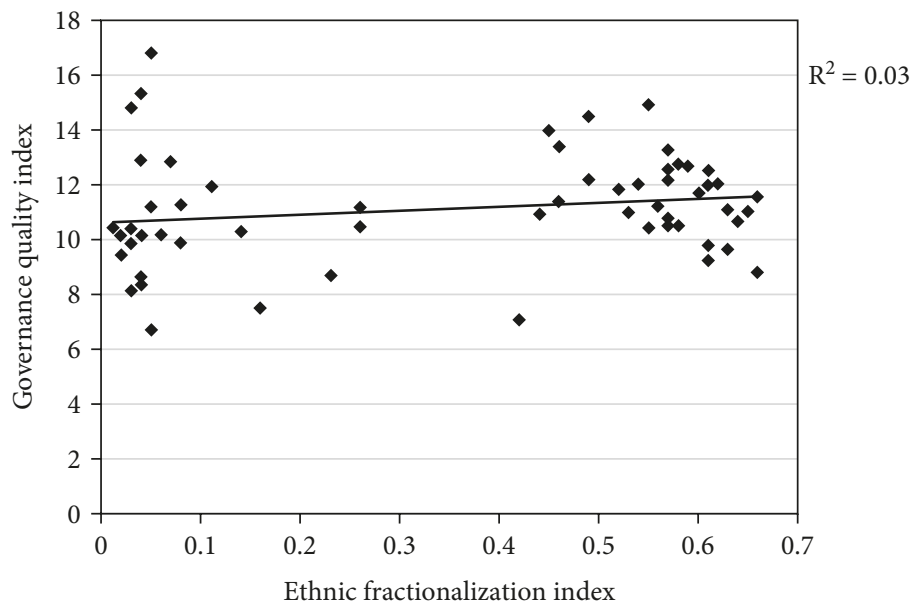

Communes

Linear (Communes)

Fig. 5: The relationship between ethnic diversity and the quality of governance at the communal level. Source: the authors' own work

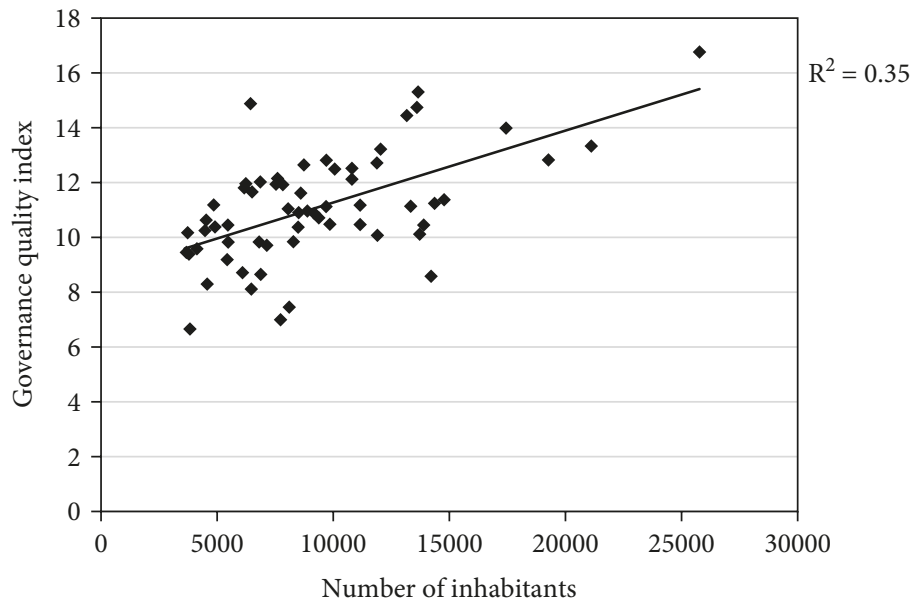

Communes Linear (Communes)

Fig. 6: The relationship between the number of inhabitants in a commune and the quality of governance at the communal level. Source: the authors' own work 


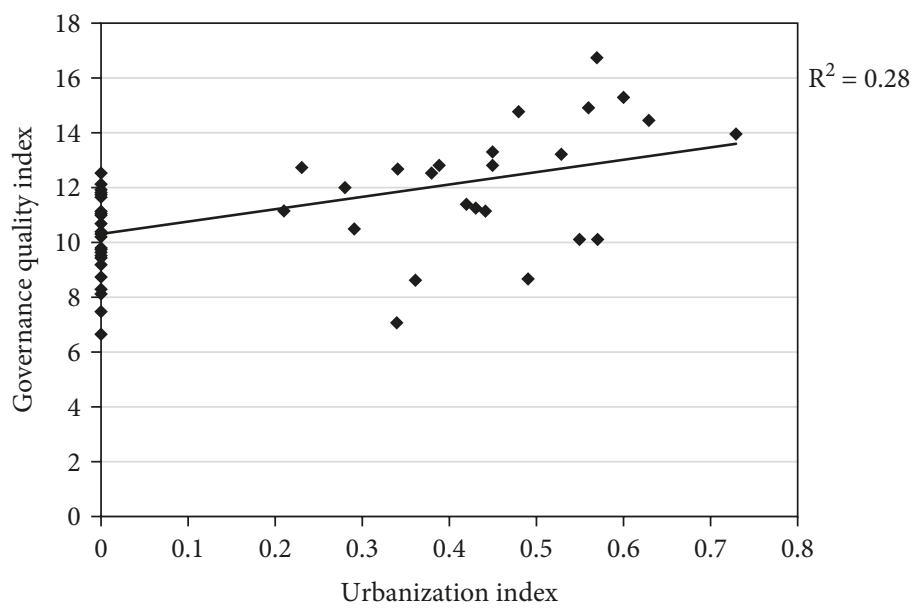

Communes Linear (Communes)

Fig. 7: The relationship between the urbanization index and the quality of governance at the communal level. Source: the authors' own work

Tab. 13: Partial correlations between EFI and the governance quality index adjusted for the impact of the selected variables

\begin{tabular}{lll}
\hline $\begin{array}{l}\text { A partial correlation between EFI and the governance } \\
\text { quality index: }\end{array}$ & Value & Relevance level \\
\hline Adjusted for the impact of the number of inhabitants & 0.297 & 0.022 \\
Adjusted for the impact of the level of urbanization & 0.332 & 0.010 \\
$\begin{array}{l}\text { Adjusted for the impact of the number of people in } \\
\text { employment }\end{array}$ & 0.170 & 0.198 \\
\hline
\end{tabular}

Source: the authors' own work.

of governance is higher than in the ethnically homogeneous rural communes. In order to verify this, we calculated additionally correlation coefficients for different sets of the communes included in our sample:

- for the communes with more than 10,000 inhabitants, no correlation between ethnic diversity and governance quality was identified;

- for the communes with fewer than 10,000 inhabitants, a statistically significant interdependence between the two examined variables was identified; 
- for the urban-rural communes, a poor and statistically insignificant correlation was identified;

- for the rural communes, a strong and statistically significant interdependence between ethnic diversity and governance quality was identified (see Tab. 14).

We also calculated the correlation between the independent variables and the particular sub-indexed of the governance quality index (Tab. 3, Tab. 6). The obtained data indicate that the participation sub-index correlates the strongest with ethnic diversity, and in many cases it is the only sub-index correlating with ethnic diversity. This tendency is so clear that it can be concluded that only one of the dimensions of the quality of governance - participation - is interdependent with ethnic diversity. Figures 8 and 9 present scatter plots illustrating this interdependence for all communes covered by the research (Fig. 8) and for the rural communes only (Fig. 9).

\section{Interpretation}

Summing up the results of the quantitative analysis, we should conclude that the hypothesis put forward at the beginning of the book was invalidated, although a picture of relationships between ethnic diversity and governance quality is more complicated, which was shown in the more detailed analysis. It is more important that while the quality of governance at the communal level does not correlate with ethnic diversity, we can observe a statistically significant and positive interdependence between the participation dimension of the quality of governance and ethnic diversity. In the multicultural communes of the Opolskie province, social participation, i.e. active citizenship and inhabitants' responsibility for the local community, is higher than in the ethnically homogeneous communes. Nevertheless, is it possible to draw conclusions about a better or worse governance quality in a given commune and the condition of the community of its inhabitants on the basis of the adopted participation indexes? For example, what is the significance of such an index as the number of non-governmental organizations per 10,000 inhabitants? According to the collected data, many more nongovernmental organizations are active in the ethnically diversified communes. But does it prove a higher level of social capital in these communes in general (and a high level of bridging social capital in particular; cf. Putnam 2007; 2008, Opioła 2019; Ziółkowski 2012) or just the opposite, i.e. a lower level of normative and cultural integration within the community (because each ethnic group develops its own institutions, hence, statistically, their number is higher)? 


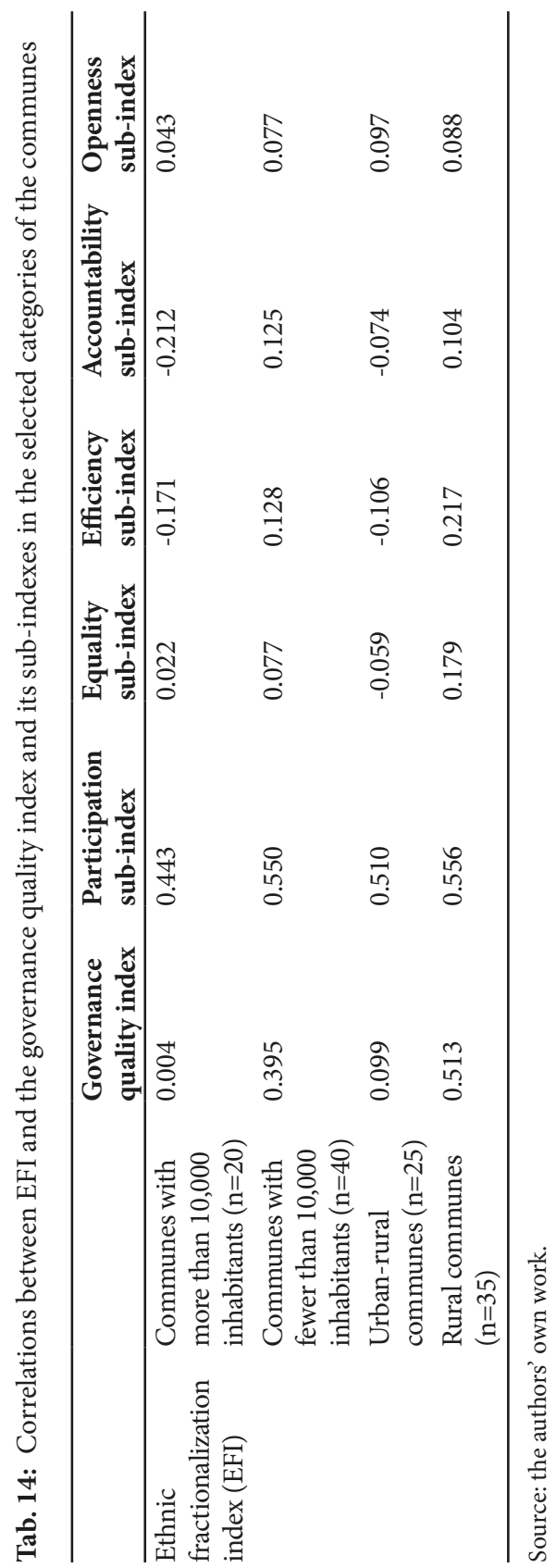




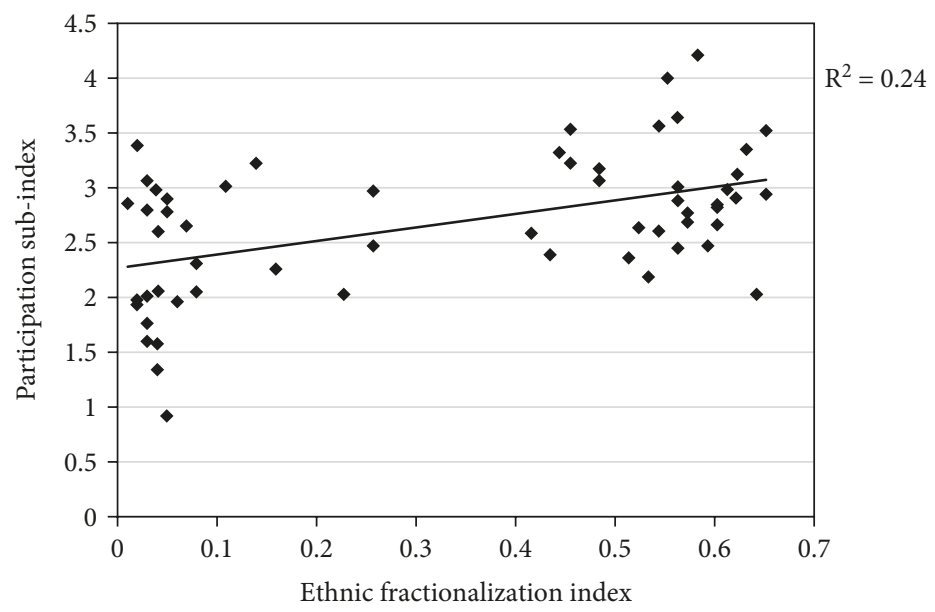

Communes Linear (Communes)

Fig. 8: The relationship between ethnic diversity and the sub-index of participation in all communes covered by the research. Source: the authors' own work

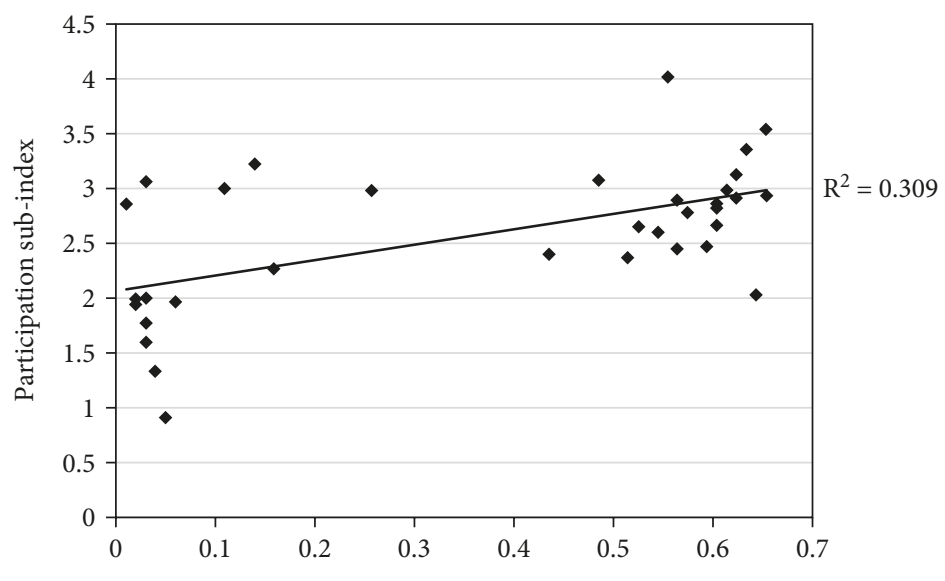

Ethnic fractionalization index

Communes Linear (Communes)

Fig. 9: The relationship between ethnic diversity and the sub-index of participation in the rural communes. Source: the authors' own work 
Another important observation is the influence of the "urban" character of a commune on the obtained values of the governance quality index. Although the urban-rural communes included in the sample are small communes with up to 20,000 inhabitants, this particular factor - the level of urbanization -exerts a significant impact on the quality of governance in a commune. Nevertheless, we still do not know what this interdependence consists in, i.e. how the fact of the existence of a town in a commune's settlement structure increases the quality of governance. Are the larger number of non-agricultural functions fulfilled by such communes and the larger percentage of people in non-agricultural employment the decisive factors? It should be remembered, however, that correlated with the governance quality index, the variable of the number of people in employment (including those employed outside agriculture) does not show any statistically significant interdependence (cf. Tables 12 and 14). The presence of a town may also influence the identity of the inhabitants of a commune, their attitudes, the frequency of interactions among them, and the existence of the cultural pattern of "center vs. periphery". How this translates into a higher governance quality is the question requiring further research. 


\section{Qualitative analysis. Case studies of selected communes}

In accordance with the adopted method of nested analysis, the statistical analysis was a stage that was to be first of all a source of knowledge about which units should be chosen for an in-depth qualitative analysis. From the quantitative analysis, we already know that there is no positive correlation between ethnic diversity and governance quality, with the exception of a clear connection between ethnic diversity and the participation dimension of good governance. However, we would like to examine more thoroughly the meaning of multiculturalism in the context of governance quality because the quantitative analysis showed that the multi-ethnic communities were characterized by greater diversity in this respect, which still entitles us to ask about the role of multiculturalism. We can assume that there are multicultural communes where this factor has some, positive or negative, influence on the quality of governance, and simultaneously there are communes where it is not of much importance. Therefore, the question whether in a particular communal context, ethnic diversity plays any role from the perspective of governance quality (not only in the participation dimension) remains topical. However, an answer to this question will not suffice to formulate generalizations about relations between our variables because it will be valid for concrete cases only. But it will make it possible to show a more multi-dimensional picture of relations in which multiculturalism and governance quality may enter in various local contexts. It may even result in debunking numerous generalizations concerning the impact of "Silesianness/ Germanness" on the quality of governance. Additionally, we would like to find out which factors may be responsible for a high or low place on our good governance scale in both multicultural and culturally homogeneous communes.

As it has already been noted in Chapter 1, we decided to apply the method of extreme cases (cf. Seawright and Gerring 2008). Therefore, for the further analysis, we selected four communes holding extreme positions with respect to governance quality. We chose two communes which are characterized by a high degree of ethnic diversity and simultaneously hold respectively the lowest and the highest positions on the governance quality scale and two such ethnically homogeneous communes:

a) Kolonowskie - an ethnically diversified commune holding the highest position on the scale of governance quality; 
Tab. 15: Selected information on the communes selected for the qualitative analysis

\begin{tabular}{|c|c|c|}
\hline & high level of governance quality & low level of governance quality \\
\hline \multirow{2}{*}{$\begin{array}{l}\text { high level of ethnic } \\
\text { diversity }\end{array}$} & Kolonowskie & Walce \\
\hline & $\begin{array}{l}\text { (number of inhabitants: } 6582 \text {; } \\
\text { ethnic fractionalization } \\
\text { index: } 0.55 \text {; governance quality } \\
\text { index: } 14.91 \text { ) }\end{array}$ & $\begin{array}{l}\text { (number of inhabitants: } 6215 \text {; } \\
\text { ethnic fractionalization } \\
\text { index: } 0.66 \text {; governance quality } \\
\text { index: } 8.73 \text { ) }\end{array}$ \\
\hline \multirow{2}{*}{$\begin{array}{l}\text { low level of ethnic } \\
\text { diversity }\end{array}$} & Paczków & Domaszowice \\
\hline & $\begin{array}{l}\text { (number of inhabitants: } 13962 \text {; } \\
\text { ethnic fractionalization } \\
\text { index: 0.04; governance quality } \\
\text { index: } 15.32 \text { ) }\end{array}$ & $\begin{array}{l}\text { (number of inhabitants: } 3897 \text {; } \\
\text { ethnic fractionalization } \\
\text { index: } 0.05 \text {; governance quality } \\
\text { index: } 6.66 \text { ) }\end{array}$ \\
\hline
\end{tabular}

Source: the authors' own work.

b) Walce - an ethnically diversified commune holding the lowest position on the scale of governance quality;

c) Paczków - an ethnically homogeneous commune holding the second highest position on the scale of governance quality ${ }^{32}$;

d) Domaszowice - an ethnically homogeneous commune holding the lowest position on the scale of governance quality.

Selecting these communes, we had to face a major dilemma, namely differences in their respective demographic potentials. The commune of Paczków has 14,000 inhabitants, Kolonowskie - 6,600 inhabitants, Walce - 6,200 inhabitants, and Domaszowice - 3,900 inhabitants. Thus, it seems that there may be some problems with their comparability, especially in view of the conclusions drawn from the quantitative analysis of relations between demographic variables and governance quality. Nevertheless, we decided to keep these cases $^{33}$, because we

32 The highest position on the scale is held by the commune of Głuchołazy, but as it is also the largest of the communes under examination (more than 25,000 inhabitants), we decided to exclude it from the groups of our case studies.

33 For the particular communes, we took into consideration various options. For example, instead of the commune of Paczków, we were considering the smaller $(10,000$ inhabitants) commune of Byczyna, which also had a high position on the governance quality scale, but still 2.5 points fewer than the exceptional Paczków. Instead of the small commune of Domaszowice, we were thinking of choosing the larger commune of Łambinowice (8,000 inhabitants), but the latter's ethnic fractionalization index was just 0.17 and its place on the governance quality scale was higher. Walce was chosen instead of the commune of Gorzów Śląski, which was larger (8,000 inhabitants) and 
assumed that their comparison was only one of the objectives of our research. What was of primary importance for us, leaving aside the comparative context, was to understand each case as a separate microworld offering data important from the point of view of the conducted research. Cases $a$ and $b$ themselves provide a significant insight in the relations included in our hypothesis, and either case $\mathrm{c}$ or case $\mathrm{d}$ offers an opportunity to ponder on local determinants of governance quality specific for a given context (after all, such opportunities are also provided by cases a and b). It does not rule out comparisons and particular conclusions drawn from such comparisons. The issue of the influence of demographic factors on governance quality acquires an interesting meaning when we focus on the fact that, slightly bigger than the commune of Walce, the commune of Kolonowskie managed to achieve a completely different result (see tab. 15). It is also worth noting that the selected communes are located far away from large urban centers (thus, they do not collect any location rent, although their locations may also influence their positions on our governance quality scale) and are peripheral units on the map of the Opolskie province.

The studies of the aforementioned cases were to allow the exploration of the following three major problems:

a) a deeper exploration of our, already disproved, hypothesis by attempting to answer the question about the significance of multiculturalism in the selected communes in the context of governance quality;

b) an explanation of potential reasons for a given commune's high or low position on the good governance scale;

c) a comparison of the features common to the communes with a high level of governance quality which, simultaneously, do not occur in the communes with a low level of governance quality, which is to make it possible to abstract the factors that influence a given commune's high position on the governance quality scale.

had a lower place on the governance quality scale, but its ethnic fractionalization index was too low. We decided to stick to the commune of Walce because of its high ethnic diversity and a very low position in the governance quality ranking, which is especially important from the perspective of the major hypothesis for this research (Walce is a complete contradiction of this hypothesis). Thus, our choice was the result of various compromises within the attempt to maintain the extreme values of the ethnic fractionalization index, the governance quality index, and demographic potential - the most important were the extreme values on the governance quality scale, but they were adjusted by taking into consideration the degrees of ethnic diversity. 
The attempt to clarify the foregoing problems will be based on an analysis of each of the communes. Such an analysis will include a description of the following dimensions of a commune:

a) a commune's governance quality profile (a more detailed presentation based on the values of the particular sub-indexes);

b) a commune's geographic and demographic position;

c) a commune's economy;

d) a commune's specific features in the material area (e.g. architecture, infrastructure, natural environment) as well as the symbolic and identity-related area;

e) a commune's political elite (the governing coalition, political leaders and their personality profiles, e.g. a bureaucrat, a visionary, a businessperson).

The case studies are based on the analysis of both secondary and primary data. The former include documents concerning a commune such as development strategies and other data published on a commune's website (or a Public Information Bulletin); academic, popular, and promotional publications; data provided by the State Electoral Commission, and press materials. We also used minutes of commune council sessions for the year 2016. They constituted a basis for an analysis of the activity of commune authorities (commune councillors), the most important issues a commune had to cope with in 2016, as well as relations between the commune leader/mayor and the commune/ town council. Access to the minutes allowed us to formulate a general view on the political situation in a commune and certain conclusions concerning the political culture of local authorities. In general, the analysis of the secondary data made it possible for us not only to obtain an insight into the unique character of a given commune, but also to prepare properly for partly structured interviews with the representatives of each commune. On the basis of the knowledge acquired from the analysis of the existing data, it was determined which issues should be raised in the particular communes in order to take into account their respective specific characters. We did not inform our respondents that the interviews concerned the quality of governance, but, similarly to the conducted questionnaire, local democracy. Selecting questions for the interviews, we were inspired by the individual interview scenario developed by Cezary Trutkowski and Sławomir Mandes (Trutkowski and Mandes 2005: 301-305) for the purposes of research on social capital in small towns. On this basis, the following general questions were formulated for each of the communes:

a) Introductory questions: How do you assess the commune's position in comparison to those in the neighboring communes? What are the most important 
advantages and disadvantages of living in the commune? Has the commune benefited from Poland's accession to the EU? What changes have occurred in the commune in connection with Poland's accession to the EU? Who, in your opinion, has the greatest influence on what happens in the commune? Is this individual persons or rather groups of people?

b) Assessment of the local authorities: How do you assess the commune council and its activities for the benefit of the commune? How do you assess the commune leader and the offices subordinate to the commune leader? Do the commune authorities have a commune development vision? If so, what are the characteristic features of such a vision? If not, what are the reasons for the lack of such a vision? Do the commune authorities cooperate with anybody from outside the commune authorities with a view to solving the commune's problems? In your opinion, are commune inhabitants satisfied with the services provided by the commune offices? What are the criteria for employing people in the commune/town office? Are contacts necessary or is employment based first of all on qualifications? Are the commune authorities involved in dialogues with inhabitants? Do they inform inhabitants of their activities, invite them to consultation sessions before making important decisions, encourage them to participate in common activities for the benefit of the commune? What should be changed in the functioning of the commune authorities?

c) Assessment of the other local stage actors

Are inhabitants interested in commune matters? If so, how does this interest manifest itself? If not, what are the reasons for the lack of interest? Are there any groups or organizations critical of the activities of the commune authorities? Do inhabitants get involved in activities for the benefit of the commune, e.g. solving the commune's problems? Do you think that inhabitants have any influence on the situation in the commune, i.e. on decisions made by local politicians, the commune's economy, infrastructure or cultural life? If such influence exists, how is it exercised? Which business enterprise has the greatest influence on life in the commune? Where does such influence result from? Do the commune authorities cooperate with businesspeople? If such cooperation exists, what does it consist in? Is there any local press (printed or online)? If so, who is the publisher? If not, what are the reasons for the lack of the press? What issues are raised by the existing press? Are there any issues that should be raised, but are not?

Thus, the case studies presented below are based on qualitative data. We are aware that an in-depth analysis of the functioning of local communities allowing 
for their comprehensive description requires rich factual materials and a genuine insight into the imagined world of the inhabitants of each commune. The collection of such materials requires a lot of time and financial resources, and the authors of the research were rather limited in their access to either of them. It seems that what acquires special significance in the examination of the quality of governance at the local level is trust from potential interviewees. It is trust that determines access to respondents and the quality of materials obtained during interviews. A solid examination of informal relations, often constituting an important dimension of governance processes at the local level, requires time necessary for winning the trust of respondents and their genuine opinions on local politics. Thus, it should be noted that temporal, personnel, and financial limitations allowed us to present a rather general picture of each commune, and the conducted case studies are of an exploratory character which is to allow a formulation of preliminary conclusions constituting an inspiration for subsequent, more in-depth research. Such conclusions will be present in the last part of the book.

\section{Kolonowskie}

\section{Governance quality profile}

The commune of Kolonowskie had the third highest governance quality index with the score of 14.91 points $^{34}$. It is simultaneously a commune with a high ethnic fractionalization index (0.55). The commune is inhabited first of all by people declaring their Polish (51\%) and German (43\%) identification. The percentage of the Silesian population is small and equals approximately $6 \%$.

In the sub-index of participation, the commune had 3.57 points (the fourth highest value among the communes covered by the research). Analyzing the particular indexes, we can indicate the following characteristic features. The commune has 18 active non-governmental organizations, including public benefit entities. Under the $1 \%$ mechanism, the public benefit organizations received 8,700 zlotys (1.33 zlotys/inhabitant). The percentage of voters supporting voters' election committees was $100 \%$ : Kolonowskie is one of the nine communes included in the research that did not have any party-based election committees. However, as it has been indicated in Chapter II, a low

34 Among the 60 communes included in the research, only the communes of Paczków and Głuchołazy had higher index values. As it has been mentioned above, Głuchołazy was not selected for case studies because of its large population. 
party dependency level is characteristic of small communes with up to 20,000 inhabitants. The number of people using the services of the commune library is relatively low (76 persons per 1000 inhabitants; the average for all communes included in the research is 128). The average mark in junior secondary school social science and history examination is $58.4 \%$, which is the fourth highest result in the research.

With respect to equality, the commune received a low score of 1.69 points. The analysis of the particular components of the sub-index shows that among 15 councillors there are 9 women (the average for the 60 communes is $30 \%$ ) and women hold two of the four managerial positions distinguished in the research (treasurer and social assistance center manager). The commune does not have a youth council or a senior citizens council. The poverty risk index is moderate and equals $0.591^{35}$.

With respect to efficiency, the commune scored 2.98 points, which is the second best result in the research. This result is based on high capital expenditures per inhabitant (336.04 zlotys), average income (1490.90 zlotys per inhabitant in 2015) and relatively high current expenditures on public administration per inhabitant (408.92 zlotys in 2014). Among all beneficiaries of social assistance, $41 \%$ were permanently dependent on it. The commune also received 1 point for using a quality management system, being one of only three communes with such a system.

With respect to accountability, the commune scored 3.67 points. The free press is present in the commune; the "Strzelec Opolski" is a weekly with a circulation of 6300 copies distributed in the Strzelecki district ${ }^{36}$. One of the journalists working for the newspaper is allocated to the commune of Kolonowskie. The newspaper as well as the website belonging to the publisher (strzelecopolski. $\mathrm{pl}$ ) presents a lot of information on the commune's local matters. The "Strzelec Opolski" is published by the Silesiana Publishing House, which is independent of local authorities. Besides the "Strzelec Opolski", the commune has one more newspaper, the "Colonnowska". Published by the Kolonowskie Town and Commune Office, it fulfils mainly the informative function. The commune's website contains a subsite with the complete documentation of conducted inspections. The level of electoral competition is also relatively high: in 2014

35 The values of the poverty risk index range from 0 to 1 , where 1 means the lowest risk of poverty, and 0 the highest. More information on this index is presented in the annex. 36 http://www.strzelecopolski.pl/strona/oferta-reklamowa (Accessed 22 May 2019). 
there were 3 candidates running for the post of town mayor. As far as property statements are concerned, all councillors and the mayor had had their statements published before 2 June 2017. Four (out of fifteen) councillors have higher education.

With respect to openness, the commune scored 3 points. It fulfilled its obligation to provide public information, answering the questionnaire in a timely manner. The commune has adopted a special resolution regulating the matter of social consultations. Minutes of council sessions are published on the commune's website. The process of cooperation with local non-governmental organizations is assessed as ineffective: organizations provide no comments on the cooperation programme as part of social consultations, and the commune has not published the said programme of cooperation with non-governmental organizations.

\section{Geographic and demographic position}

Kolonowskie is an urban-rural commune located in the eastern part of the Opolskie province, in the Strzelecki district. The commune consists of four communities: Kolonowskie, Staniszcze Wielkie, Staniszcze Małe and Spórok, as well as the quarter of Fosowskie (an administrative part of the town of Kolonowskie, with its own quarter council and chairperson). The commune is inhabited by close to 6000 people, of which 3380 in Kolonowskie. In the years 1945-1950 the seat of the commune authorities was the village of Staniszcze Wielkie. The commune is characterized by a low population density $\left(71\right.$ persons $\left./ \mathrm{km}^{2}\right)$, which results from a large share of forests in the commune's surface area $(75 \%)$. It is located in the northern part of the Strzelecki district, close to the borderline between the Opolskie province and the Sląskie province. The location is peripheral with respect to both the provincial capital $(35 \mathrm{~km}$ along a provincial road or a railway line) and the district authorities seat in Strzelce Opolskie $(23 \mathrm{~km}$ along local roads). Nevertheless, the commune has other advantages resulting from its location and historical development. It is located in the valley of the Mała Panew River, which is used for tourist purposes. In the 18th and 19th centuries, on the initiative of count Filip Collona, the local landowner, the commune became the place of the intensive development of the steel industry.

There are 18 active non-governmental organizations in the commune. These are five voluntary fire service units, four DFK (Deutsche Freundschaftskreise) circles, a choir and orchestra, as well as three sports clubs. There are also associations whose scopes of activities are broader than local. These are the Success Embassy Association providing assistance to people after laryngectonomy procedures and the "Siedlisko" Association offering help to people with 
disabilities and running a nursing home in Staniszcze Wielki and a social enterprise offering employment to young people with intellectual disabilities ${ }^{37}$.

\section{Economy}

The history of the town of Kolonowskie is connected with the establishment of a steelworks by count Filip Collona in 1780. From the beginning of its existence Kolonowskie was a place where the steel industry was developing intensively. At some time there were two blast furnaces operated in the territory of the commune. In the middle of the 19th century a railway line was laid through Kolonowskie. At the beginning of the 20th century a cardboard factory was opened in the town. It is still an active enterprise operating under the business name of Packprofil sp. $\mathrm{z}$ o.o. The commune's largest enterprise is the factory run by the company Izostal specializing in anti-corrosion protection of steel pipes. The company moved its operations to Kolonowskie from the neighboring commune of Zawadzkie in 2009. It was an important event for the local economy. In the territory of the commune there are a number of small and medium-sized businesses representing the steel, wood processing, paper production, and transport industries. There are also many inhabitants providing tourist services (rental of kayaks and bicycles, organization of kayak trips, agrotourism, lodging services, organization of anniversary events). Altogether there are 190 business enterprises registered in the commune ${ }^{38}$. The commune's characteristic feature is a very low level of unemployment. In comparison to the neighboring communes, a high percentage of inhabitants are employed in the territory of the commune and thus do not have to spend time and financial resources on commuting to work (Wywiad z przedstawicielem kierownictwa gminy 06.06.2019). In 2016 the share of the unemployed in the working-age population was $3.2 \%{ }^{39}$. Kolonowskie is the least agriculturally developed commune in the Opolskie province. This is caused by both the low percentage of agricultural land $(21.4 \%)$ and the low quality of soil.

It is worth mentioning that in the 1990s Kolonowskie and the neighboring communes of Ozimek and Zawadzkie were hit by the collapse of the steel industry

37 http://www.siedlisko.org.pl/firma_spoleczna.html (Accessed 5 July 2019).

38 Strategia Rozwoju Gminy Kolonowskie na lata 2016-2022; http://www.bip.kolonowskie. $\mathrm{pl} /$ download/attachment/22828/uchwala-nr-xv10716-w-sprawie-przyjecia-strategiirozwoju-gminy-kolonowskie.pdf (Accessed 27 May 2019).

39 https://opole.stat.gov.pl/vademecum/vademecum_opolskie/portrety_gmin/strzelecki/ gmina_Kolonowskie.pdf (Accessed 05 June 2019). 
and the consequent sudden increase of unemployment and falling importance of the Fosowskie rail hub ${ }^{40}$. The development of tourist services became an idea for dealing with the economic problems of the local population and time has shown that it has been a successful plan. At present many inhabitants provide tourist services (rental of kayaks and bicycles, organization of kayak trips, agrotourism, lodging services, organization of anniversary events). The commune actively uses available European and domestic funds, executing various projects in the areas of tourism, education and infrastructure. It has a wide network of contacts with partner towns in Germany, Slovakia, Austria and the Czech Republic. Kolonowskie is the only Polish commune to have joined the Climate Alliance $(\text { in } 2006)^{41}$.

\section{Specific features in the material, symbolic, and identity-related areas}

Present in the consciousness of its inhabitants, the specific features of the Kolonowskie commune include the multicultural identity of its inhabitants, as well as its natural and tourist advantages. The history of settlement in the commune is not long. The oldest village is Staniszcze Wielkie, which in the Middle Ages functioned as a small hunting settlement of the Upper Silesian Piasts ${ }^{42}$. The development of settlement in the territory of the commune is connected with Frederick's colonization, i.e. the establishment of German settlements in Silesia in the second half of the 18th century. It was in that period that count Filip Colonna, the owner of the local land, established the villages of Spórok, Kolonowskie and Fosowskie (at present a quarter of the town of Kolonowskie) and started to develop the steel industry. In the whole valley of the Mała Panew River, sixty new colonies were established. The Silesian and German populations living together and the industrial character of the settlement structure defined the identity of the local community in the 19th century (cf. Rajman 2003). Some of the original settlements do not exist anymore, but their remains are present in the area's topography (e.g. the old hamlet and steelworks of Regolowiec on the Bziniczka River, which now is a camping ground of the Zawadzkie Forestry Commission, with the preserved traces of old buildings and information boards).

40 An interview with Józef Kotyś in Radio Opole on 20.08.2018: https://www.youtube. com/watch?v=gl2cDv4ZnaE (Accessed 20 June 2019).

41 http://kolonowskie.pl/6911/9427/wolfsgraben.html (Accessed 27 May 2019). The Climate Alliance is an initiative of over 1700 towns and communes from 26 European countries (http://www.climatealliance.org/about-us.html; Accessed 27 May 2019).

42 http://kolonowskie.pl/2891/9400/staniszcze-wielkie.html (Accessed 28 May 2019). 
That the tradition of multiculturalism is important for the commune is proved by the content of its mission included in the Commune Development Strategy for the Years 2016-2022: "The development of the economy and services oriented towards the improvement of the standard of living in the commune with the simultaneous preservation of the natural environment and the multicultural character of the local community"43. Multiculturalism is closely connected with the cultural, social and political activities of the commune's inhabitants and authorities. In the commune there are four DKF (Deutsche Freundschaftskreise) circles. In three churches located in the commune, Sunday masses are celebrated in the German language. Within the scope of the project executed by the commune of Kolonowskie in cooperation with the Czech microregion of Hranicko, all local sites of memory (roadside crosses and figures, shrines, sculptures, architectural monuments) were provided with information boards in the four languages: Polish, Czech, German, and English. The commune's educational units take advantage of an additional subsidy for the teaching of the German language: in the 2016/2017 school year the subsidy amounted to 1.086 million zlotys $^{44}$. In comparison to the other communes and taking into consideration its size and resources, Kolonowskie is also involved in relatively many projects in which foreign partners participate. Under the Operational Programme of PL-CZ Transborder Cooperation, the commune has carried out or is currently carrying out five projects together with the Czech commune of Belotin and the Czech microregion of Hranicko ${ }^{45}$.

The other important element of the local community's identity is the awareness of the commune's tourist potential and the related care of the environment. As it has been mentioned above, Kolonowskie is the only Polish commune to have joined the Climate Alliance. Membership in this movement is connected with Kolonowskie's partnership with the Austrian commune of Wolfsgraben also a member of the Climate Alliance. On the initiative of a former inhabitant of Kolonowskie, on the very same date (20 June 2006) the commune signed

43 Strategia Rozwoju Gminy Kolonowskie...

44 Informacje o wysokości środków przeznaczonych dla poszczególnych samorządów na oświatę mniejszości narodowych i etnicznych oraz na nauczanie języka regionalnego w ramach części oświatowej subwencji ogólnej w roku 2017. Accessed 28 May 2019 at: http://mniejszosci.narodowe.mswia.gov.pl/mne/oswiata/informacje-dotyczace-o/ rok-szkolny-20162017/10697,Informacje-o-wysokosci-srodkow-przeznaczonych-dlaposzczegolnych-samorzadow-na-o.html.

45 http://kolonowskie.pl/2927/9368/program-operacyjny-wspolpracy-transgranicznejrcz-rp-2007-2013.html (Accessed 28 May 2019). 
a partnership agreement with Wolfsgraben and joined the Climate Alliance ${ }^{46}$. In consequence of this, the commune authorities undertook to implement the provisions of the Kyoto Protocol.

The importance of environmental protection is also emphasized in the commune's development strategy. It is its second most important strategic objective pursued, among other things, through the implementation of the Low-carbon Economy Programme, the elimination of asbestos products, educational activities, the liquidation of illegal landfills, and the proper disposal of waste from water treatment plants ${ }^{47}$. The higher than average ecological culture of the local community can also be noticed in other projects. In the recent years considerable capital expenditures were incurred on connecting successive villages to the natural gas network, which will allow a reduction of households heated with hard coal. Furthermore, various initiatives are to draw attention to the commune's natural environment and its protection. A case in point is the composting toilet at Little Bird Pond in Spórok that was opened in May 2018. It is one of the elements of the so-called Eco-stop: a place of rest in the forest near the village where, beside tourist infrastructure, visitors can take advantage of an environmental education center (Interview 1). In 2018 the Eco-stop won the first award in the "Beautiful Regional Village" competition".

Care of the environment in the commune is connected with expenditures on the development of tourist infrastructure. Kolonowskie was one of the first communes in the province that started to mark out recreational bicycle paths. These activities were initiated by the then mayor of Kolonowskie in $2001^{49}$. On the initiative of the Kolonowskie commune council, seven communes of the region signed an agreement for the joint marking out of a network of bicycle paths (Stecki 2001). At present there are a few bicycle routes running across the

46 http://kolonowskie.pl/2938/miasta-partnerskie.html (Accessed 31 May 2019).

47 Strategia Rozwoju Gminy Kolonowskie... p. 9.

48 http://www.odnowawsi.eu/docs/14_informacja_o_laureatac2.pdf

(Accessed 6 July 2019).

49 See the pre-election debate of candidates for mayor in the 2018 elections in Radio Opole: https://www.youtube.com/watch?v=qU8GXii9DGs (Accessed 2 June 2019). As the then mayor mentioned in one interview, the idea for the development of tourist services had originated from the observations of how the inhabitants of the German commune of Gehrden spent their free time. It is an interesting example of the efficiency of the international partnerships among towns and communities. See the interview with Józef Kotyś in Radio Opole on 20 August 2018: https://www.youtube.com/ watch? $\mathrm{v}=\mathrm{gl} 2 \mathrm{cDv} 4 \mathrm{ZnaE}$ (Accessed 20 June 2019). 
Tab. 16: The composition of the Kolonowskie commune council during the terms 2002-2018

\begin{tabular}{lllll}
\hline $\begin{array}{l}\text { Name of election } \\
\text { committee }\end{array}$ & 2002-2006 & 2006-2010 & 2010-2014 & 2014-2018 \\
\hline Concord and Dialogue & 3 & - & 5 & 1 \\
German Minority & 12 & 10 & 10 & 6 \\
Safe Commune & - & 5 & - & - \\
$\begin{array}{l}\text { Our Commune } \\
\text { Kolonowskie }\end{array}$ & - & - & - & 8 \\
\hline
\end{tabular}

Source: the authors' own work based on the data from the National Electoral Commission.

territory of the commune. One route was marked out around the commune of Kolonowskie. Also, there are three bike rental establishments in the commune.

Another activity, even more important from the point of view of taking advantage of the commune's tourist potential, is the development of the Mała Panew River for the purposes of kayak tourism. It was initiated in 2006 when the first agrotourism farm bought a set of kayaks (Interview 2). At present there are at least eight micro-enterprises specializing in the rental of kayaks and the organization of kayak trips. The commune has a few kayak marinas and offers kayak routes of various lengths. All enterprises providing kayaking services in the territory of the commune have 614 kayaks altogether. The commune supports these entrepreneurs, for example by participating in tourism fairs, organizing kayak traffic along the river, providing sanitary facilities at kayak marinas, modernizing and developing roads and car parks at marinas, and publishing tourist maps ${ }^{50}$.

\section{Political life}

A characteristic feature of the commune's political life is the long-lasting domination of the German minority, which, however, is accompanied by a gradual development of effective political competition from non-party election committees (see tab. 16). Already in the years 1990-1994, i.e. during the first term of local government authorities elected in free elections, one of the regional leaders of the German minority was elected mayor of the commune. The same politician held the post of mayor in the years 1998-2006 to be replaced by another

50 An interview with deputy mayor Konrad Wacławczyk in Radio Doxa, 26 July 2019 (Accessed 2 August 2019). 
German minority representative, who at present holds this post for the fourth term (2018-2024). This phenomenon of the same person's holding the post of mayor for a few terms in a row is characteristic of small communes (Bartnicki 2015: 67) ${ }^{51}$. It should be emphasized that the aforementioned mayors had been elected with the clear support of the majority of the inhabitants already in the first round of elections (in 2010 the incumbent mayor had no rivals and won the non-competitive elections with the support of $76 \%$ of the voters). The situation changed in 2014 when the "Our Commune Kolonowskie" Voters Election Committee nominated its own candidate for mayor. In the 2014 elections the second round was necessary. The winner was the incumbent mayor, who won with the majority of $55 \%$ of votes. In the subsequent elections - which are outside the scope of this analysis, but illustrate a certain trend - the mayor representing the German minority lost the first round, but because his rival from the "Our Commune Kolonowskie" Voters Election Committee did not pass the threshold of $50 \%$ of votes necessary for victory (he received $49.95 \%$ of votes), the second round had to be held. But in the second round, the inhabitants supported the incumbent mayor, who won with a slight majority of votes $(51.1 \% \text { to } 48.9 \%)^{52}$.

Table 16 shows also that the town council was dominated by councillors representing the German minority. In the years 2002-2010 the town council was dominated by two committees: Concord and Dialogue and German Minority (registered as the German Minority Election Committee or the Election Committee of the Social and Cultural Association of Germans in Opole Silesia). The 2006 elections constituted a certain exception because the "Concord and Dialogue" Voters Election Committee did not register a list of candidates and all seats in the council were taken by the "German Minority" Election Committee and the "Safe Commune" Voters Election Committee. Nevertheless, it should be emphasized that in 2006 the councillors representing Concord and Dialogue in the previous and subsequent election were candidates in the lists of Safe Commune and the two Election Committees that appeared in 2006: Law and Justice (Prawo i Sprawiedliwość - PiS), and Silesian Autonomy Movement. The nomination of one PiS candidate in the elections to the town council in 2006,

51 This phenomenon is characteristic first of all of small rural communes. After the 2014 elections $32 \%$ of 1569 such communes had commune leaders who had been in office since 2002 (the percentage of commune leaders who had not held the post during the previous term was the same). In the case of urban-rural communes, $21 \%$ of them had mayors who had held their posts non-stop since 2002 (Bartnicki 2015: 67).

52 All data included in this paragraph come from the website of the National Electoral Commission: www.pkw.gov.pl. 
who eventually did not win a seat on the council, was the only party-related element in the latest history of the local government in Kolonowskie. The party structures in the commune are weak and the political parties may count on support only in the case of the highest level elections (Interview 3).

In higher level elections, it is politicians representing the German Minority or the Civic Platform that receive the most support. In the recent years the most votes were cast for the following parties:

- in the 2014 district council elections: the Civic Platform and the German Minority,

- in the 2014 provincial assembly elections: the German Minority,

- in the 2015 parliamentary elections: the Civic Platform and the German Minority.

Thus the Civic Platform is the party enjoying the greatest support in the commune. Nevertheless, at the local level, this party has never organized an election committee in the commune. The phenomenon of support for the Civic Platform is partially explained after a personal analysis of votes cast for the party's candidates in the commune. In the 2014 district council elections, out of 852 votes cast for Civic Platform candidates, 761 were won by Janusz Żyłka, a member of the Strzelecki district board (an inhabitant of the Kolonowskie commune). Similarly, in 2015, out of 611 votes won by the Civic Platform in the parliamentary elections, 514 votes were cast for Mr. Żyłka. Thus, it is a phenomenon of a strong leader rather than a strong political party as such. In the years 20142018 Janusz Żyłka was a member of the Strzelecki district board, and in 2018 he was the rival of the incumbent mayor in the local government elections. He has sat on the regional board of the Civic Platform in Opole since 2017 (Janowski 2017). He is also a member of the popular duet of Dominika and Janusz Żyłka composing and playing so-called Silesian hits ${ }^{53}$.

What attracts attention is the commune's low support for the Polish Peasants' Party (Polskie Stronnictwo Ludowe - PSL), a party traditionally strong in small communes. There are two reasons for this state of affairs. Firstly, in communes with a high percentage of Germans or Silesians, the PSL is replaced by the Social and Cultural Association of Germans in Opole Silesia. It is a non-governmental organization animating the social and political life of the German minority. It also nominates its own candidates in various elections (usually as the German

53 http://www.januszzylka.pl/ (Accessed 5 June 2019). 
Minority Election Committee $)^{54}$. Secondly, Kolonowskie is not an agricultural commune. In comparison to other small urban-rural communes, Kolonowskie's high percentage of the population working in the production and nonagricultural services sectors determines to a certain extent the electoral profile of the community.

As it has been mentioned earlier, the year 2014 witnessed a new electoral initiative called the "Our Commune Kolonowskie" Voters Election Committee. It was established as an alternative to the German Minority, which had governed the commune for many years. It should be noted that some groups of the inhabitants became convinced that the long period of the German Minority's rule was not good for the commune as its beneficiaries were a small group of people connected with the local authorities. Such opinions critical of the German Minority and the mayor were presented, for example, in the "Strzelec Opolski" newspaper. During the 2014 election campaign and the 2014-2018 term of office there appeared anonymous accusations of the commune's being controlled by the "minority mafia" (or the "Kolonowskie" mafia), i.e. a network of connections advantageous first of all for the members of the German Minority ${ }^{55}$. The mayor was accused of the lack of competences ("besides being a German Minority mayor, he has no talent, knowledge, or professionalism") ${ }^{56}$. The campaign of the candidates for the post of mayor (in the 2014 elections, the second round was necessary) contained also negative elements (e.g. spreading rumors about the rival), and the contenders themselves described it as fierce ${ }^{57}$. The most controversial incident was putting up electoral obituaries that notified of "the departure of the incumbent mayor into political oblivion". Despite reactions from the provincial office of the State Electoral Commission and a notification filed with the police, it was impossible to establish who had initiated such a negative form of the election campaign (ibid. 2014).

54 About the role and strength of the Social and Cultural Association of Germans in Opole Silesia as the main platform of the German minority's political participation in local government authorities - see Mazurkiewicz 2017a. The issue of the Social and Cultural Association of Germans in Opole Silesia appears also in the next case study.

55 See for example comments of readers under one of the articles in the "Strzelec Opolski": http://www.strzelecopolski.pl/artykul/o-wlos-od-zwyciestwa (Accessed 4 May 2019).

56 See a comment for an article in the "Strzelec Opolski": http://www.strzelecopolski.pl/ artykul/trzeba-sprzedac-przystan\#comments (Accessed 4 July 2019).

57 http://www.strzelecopolski.pl/artykul/mamy-burmistrza (Accessed 5 May 2019). 
Already in the first elections after its establishment the "Our Commune Kolonowskie" Voters Election Committee won the majority in the town council with 8 seats (see the Table) ${ }^{58}$, and its candidate for mayor became a real threat to the incumbent mayor representing the German Minority, only to lose in the second round with the political capital of $45 \%$ of votes. The property statements of the councillors representing "Our Commune Kolonowskie" show that they are self-employed entrepreneurs or people working in the private sector. Therefore, as councillors, they are "independent" of the mayor because they do not need to participate in the local system of commune institutions in order to use public resources to build their political positions. Despite this, an analysis of the minutes of town council sessions shows that cooperation between the mayor and the council is of a conciliatory character. In view of the fact that the mayor's group does not have a majority in the town council, the commune's political regime can be classified as a model of a strong mayor controlled closely by a council (Swianiewicz and Klimska 2003: 23). The strategy followed by the majority group of "Our Commune Kolonowskie" is one of cooperation as opposed to one of competition. Draft resolutions proposed by the mayor are not torpedoed, just the opposite, the decisive majority of them are passed unanimously ( $95.4 \%$ of the resolutions on which the council worked in 2016 were passed unanimously; only one resolution was rejected). On the other hand, fulfilling the idea of serving the community and being responsible before it, the mayor treats the council as an important political entity, which manifests itself, for example, in undertaking interventions in matters reported by the councillors and implementing resolutions adopted on the council's initiative. The councillors representing the mayor's political group are more active in the council than the councillors of the majority group (taking into consideration the average number of questions asked and motions proposed per councillor). During the eight analyzed council sessions held in 2016 out of the 139 questions or motions, 133 of them came from the councillors (the others came from village leaders). Each of the councillors was active at least once during the course of the year and eight of them were very active, putting forward questions or motions on more than ten occasions.

The tendencies described above prove the gradually growing dissatisfaction with the rule of the German Minority, despite the objective successes of the

58 In the 2018 elections, the "Our Commune Kolonowskie" Voters Election Committee increased the number of seats on the council to 11 at the expense to the German Minority Voters Election Committee, which holds just four seats on the council during the term of office 2018-2022. 
commune authorities that are reflected in both our governance quality index and all-Poland community rankings ${ }^{59}$. During the course of the conducted analysis we did not identify any deep social or political conflicts, despite the appearance of effective competition in the form of the "Our Commune Kolonowskie" Voters Election Committee.

The compact character of the settlement network and the small number of the villages cause the commune to be well integrated; there are no conflicts among the villages and the local communities are not shut to the outside world. The topics that raised discussions and controversies during the term of office 20142018 concerned mundane matters such as the sequence of local road modernization operations or the activities of the local water supply and sewage disposal enterprise. A case in point was the discussion concerning the repair of Szkolna Street, which was initiated during the election campaign. The rival of the incumbent mayor was of the opinion that it was one of the most important streets in the town, which should have been repaired a long time before. The mayor defended himself, claiming that because he lived at Szkolna Street, he had not wanted to be accused of taking advantage of his position for private gains ${ }^{60}$.

\section{Attempt to explain the governance quality profile}

In our opinion, the high quality of governance in the commune of Kolonowskie is determined by a few factors the most important of which are the industrial and tourist character of the commune's economy, the high level of the local leaders' social capital, and the strong rootedness of the local community.

The contemporary development of the Kolonowskie commune results from historical conditions. The commune does not have agricultural traditions and since the 18th century, i.e. the beginning of intense settlement in its territory, its character has been industrial. The local population worked first of all in the metallurgical and timber processing industry. The high level of afforestation did not allow the development of agriculture on a large scale. On the other hand, the specific character of the population's economic activities was reflected in the settlement network, which is compact and sometimes resembles factory workers'

59 For example, in the ranking prepared by the "Rzeczpospolita" daily in 2018, Kolonowskie took the 51st place among 857 urban and urban-rural Polish communes, and the third place in the same category in the Opolskie province (behind Brzeg and Grodków). Source: https://rankingsamorzadow.rp.pl/wyniki\#result (Accessed 8 April 2019).

60 See the pre-election debate between Norbert Koston and Janusz Żyłka in Radio Opole: https://www.youtube.com/watch?v=qU8GXii9DGs (Accessed 2 June 2019). 
housing estates. All this has positive consequences for governance quality. For example, the compact arrangement of buildings made it possible to connect $98 \%$ of the households in the commune to the sewer system (Interview 3$)^{61}$. Such a spatial arrangement is also a factor facilitating social integration at the level of the particular villages. They are located close to one another, sometimes without any visible borders. Spórok is the only village located at a clear distance from the others; it lies $3 \mathrm{~km}$ to the south-east of Staniszcze Małe. The commune has a high urbanization index (0.56), which in our research correlates positively with governance quality (see Chapter 4). The status of the town and the development of tourism in the commune cause a high percentage of its territory to be public space where inhabitants meet one another or people visiting the commune. Examples of such public space include kayak marinas on the Mała Panew River, agrotourism farms, boarding houses, restaurants, and public facilities belonging to the commune such as schools, kindergartens, day-care rooms, sports fields, a concert hall, squares, offices, a museum, etc.).

The lack of strong agricultural traditions in the commune is connected with the relative weakness of the agricultural model of life and system of values. According to sociologists and ethnographers, in this model, land and farm are of primary importance, and the life of a family is subordinate to their needs pursuant to the rhythm of passing days and seasons. In this model, a family provides cheap labor and social life concentrates on assistance provided by neighbors or relatives in the performance of agricultural work, while the manner of spending free time is determined by the church and religious customs (cf. Drozd-Piasecka 1988; Halamska 2013). Hence, we assume that in such conditions, particularisms characteristic of so-called amoral familism will play a smaller role and the appearance of bridging social capital will be more probable.

A big share of tourist services in the commune's economy results also in frequent meetings between the local population (the owners of kayak rental businesses, agrotourism farms, restaurants) and people coming from other regions to take advantage of Kolonowskie's tourist offer. During such meetings people talk, share their experiences and good practices, exchange opinions, and build interpersonal relations. On the other hand, the commune's inhabitants working in the tourist sector travel to various cities for promotional purposes

61 According to the Local Data Bank of the Central Statistical Office, in 2017 the percentage of the inhabitants of the Kolonowskie commune with access to a sanitary sewage system was $86 \%$, which is a very high ratio in view of the fact that the average for the Strzelecki district is $77 \%$, and for the Opolskie province $-73 \%$. 
(e.g. tourist fairs in Opole, visits to partner communes) and return home with new ideas for the improvement of the quality of life. In a commune of such a character, the mobility of inhabitants is greater than in a typically agricultural commune.

In our opinion, another important factor is the high level of the local leaders' social capital. For example, the deputy head of the Strzelecki district office and the former deputy marshal of the Opolskie province come from Kolonowskie. Both of them exert influence on the local cultural and political life. In 2018 the deputy head of the district office (previously a member of the district board) was the candidate of the "Our Commune Kolonowskie" Voters Election Committee for the position of mayor. He is also an active member of the regional structures of the Civic Platform. The former deputy marshal is now director of the Library and Cultural Centre in Kolonowskie. He is also one of the leaders of the Social and Cultural Association of Germans in the Opolskie province. The activities of both politicians exceed the limits of local politics. Both of them have acquired strong social and political capital, which may constitute an important "asset" in the political life of the commune. Such capital is based on the practical knowledge of how district and provincial offices function, announced competitions, recruitment procedures, regional or national programs, etc., as well as contacts with people operating in this area. These two politicians are the most prominent examples, but it should be added that a few other persons who can be regarded as having considerable social capital of a bridging or linking character are also connected with the Kolonowskie commune personally or professionally.

It is also worth noting that membership in various associations or organizations aiming to improve the quality of provided public services is a natural phenomenon in the commune. Selected tasks from the scope of communal services are carried out within the framework of an association of communes called "The Clean Region". Public transport services are provided by the communal association called "Ride with Us"62. In the opinion of the commune authorities, cooperation within such organizations is beneficial for Kolonowskie, while

62 Established in 2008, “The Clean Region” Inter-communal Association specializes in waste management. It comprises eleven communes from the Strzelecki, Kędzierzyńskokozielski and Krapkowicki districts. "Ride with Us" Special Purpose District and Communal Association carries out tasks related to public transport on roads. It consists of the Strzelecki district and all seven communes located in the territory of the district. Inter-communal associations perform public tasks entrusted to them by particular communes. Such a solution allows small communes to fulfil their public tasks with greater efficiency. 
communes that perform such tasks individually have to wrestle with problems. A decision to establish cooperation with the inter-communal association was, among other things, the effect of observations of solutions functioning in Kolonowskie's partner communes in Germany (Interview 3). Taking advantage of good practices observed in partner communes appears often in the utterances of local leaders (also in the context of creating a network of bicycle paths or developing kayak tourism). In our opinion, it is yet another proof for the positive use of social capital held by local leaders. Another example of well used social capital of a linking character is how the commune coped with the flood in 2010. Despite the fact that for coping with such critical situations, the commune has only a network of voluntary fire service units, according to the mayor, the commune dealt with the flood so well that no help from the outside was necessary and the commune's voluntary fire service units were able to help the neighboring commune to deal with the consequences of the flood (Interview 3 ).

The last factor which, in our opinion, deserves closer attention is the rootedness of the commune's inhabitants in the local community and the maintenance of the continuity of local social institutions. In comparison to many other communes in the province, Kolonowskie did not suffer much in consequence of the two world wars. Post-war relocations affected a relatively small part of the local community. Also, the number of relocatees from the Eastern Borderlands was not large. The pre-war enterprises such as the timber preserving plant and the cardboard factory had not been destroyed and resumed operations soon after the war, maintaining the local structure of industry and employment. The current owners of these enterprises refer to their pre-war history: Packprofil (cardboard manufacture), Kopgard (timber preservation).

The local collective memory is fostered not only by businesspeople. In consequence of the joint execution of a project with a Czech partner, the commune inventoried and documented all local places of remembrance. They were subsequently provided with detailed information boards in the Polish, Czech, German and English languages. There are several dozen such places in the territory of the commune. Similar information boards were put next to architectural monuments such as roadside crosses and shrines. Presented information is often based on the oral traditions of the local community. For example, one of the crosses standing in the forest commemorates a suicide committed by a local inhabitant; the roadside shrine in the centre of the village commemorates an accident in which a horse-drawn cart knocked down a groups of pilgrims on their way to the sanctuary on St. Anna's Mountain, and the stone shrine standing at one of the private buildings is a votive offering from the commune's former inhabitants who had emigrated to the United States before the war. 
Many dozen such stories were collected in the territory of the commune. On the one hand, it enriches its tourist potential and, on the other hand, it proves a high level of the rootedness and a strong sense of community of the present inhabitants of Kolonowskie. In our opinion, rootedness in the local community combined with the spirit of enterprise and the predominantly non-agrarian model of life is one of the factors determining the high quality of governance in the commune.

With regard to the key issue of our research, i.e. the influence of ethnic diversification of governance quality, we observe a few regularities.

Firstly, in the everyday practice of local politics and in the media discourse concerning the commune, we observed no tendencies to distinguish Silesianness as an identity equivalent to the Polish and German ones. Silesianness is rather a cultural category related to the local dialect used by some inhabitants, secular and religious customs, local music, etc. Poles and Germans constitute two groups of inhabitants which are politically empowered; however, at the local level, ethnic issues are raised exclusively by German minority activists (through the name of the minority's association, the institutions of social life, and partly their programme). Holding the majority of the seats in the town council, the "Our Commune Kolonowskie" committee does not define itself with respect to any ethnic category.

Secondly, there are no social conflicts among the particular ethnic groups. Even the negative campaigns conducted by the competitors for the post of mayor in the local elections held in 2014 and 2018 did not result in any greater conflicts. Just the opposite, the commune offers numerous examples of cooperation for the benefit of the local community. We did not observe any activities which could be interpreted as manifestations of one group's hostility towards another (e.g. destroying bilingual village name plates, painting offensive texts on walls, ethnically motivated assaults).

The third regularity is the aforementioned monopolizing (but also participatory) mechanisms of the institutions of the German minority. Through their institutions and with the support of the regional structures of the Social and Cultural Association of Germans, local German minority activists are able to maintain a high level of their members' mobilization to ensure not only victory in local elections but also the smooth functioning of local social life organizations (voluntary fire service units, parish councils, village councils, sports clubs). Such monopolization, however, does not cause social polarization. It should be noted that a similar mechanism is observed in many communes in the Opolskie province, governed or co-governed by the German minority. 


\section{Walce}

\section{Governance quality profile}

The performed quantitative analysis shows that the commune of Walce holds one of the lowest places on the governance quality scale and the lowest one among the communes with a high ethnic fractionalization index. In the case of Walce, this index equals 0.72 . In light of the data from the 2002 census, $32 \%$ of the commune's inhabitants (2014 people) declared to be of German nationality, $16 \%$ (965 people) - of Silesian nationality, and $39 \%$ (2412 people) - of Polish nationality. No national identity was established for $13 \%$ (818 people) of the population. This means that inhabitants declaring Polish nationality constituted a minority in the commune of Walce. The value of governance quality index for the commune equals 8.73 points. Walce scored 3.53 points in the sub-index of participation. The analysis of the particular indexes shows that there are 20 nongovernmental organizations conducting activities in the commune (including 7 voluntary fire service units and 7 regional units of The Social and Cultural Association of Germans in Opole Silesia). They include public benefit entities, which on average acquired 1.08 zlotys per inhabitant (in total 67223 zlotys) under the $1 \%$ mechanism. The percentage of voters supporting voters' election committees is $100 \%$. The number of people using the services of the commune public library is relatively high (155 per 1000 inhabitants). The average mark in junior secondary school social science and history examination is 51.8 points.

With respect to equality, the commune scored 1.54 points. Women constitute $40 \%$ of commune councillors and hold two of the four managerial positions in the commune (commune secretary and social assistance centre manager). The commune does not have a youth council or a senior citizens council. The poverty risk index is 0.639 (the value of 1 indicates the lowest poverty risk level), which constitutes a relatively good result against the background of the whole province.

In the dimension of efficiency, the commune's index equals 2.46. This resulted from relatively high capital expenditures (640 zlotys per inhabitant), a low level of the commune's own income (1112.19 zlotys per inhabitant) and 346.60 zlotys per inhabitant spent on public administration. Among all beneficiaries of social assistance, $33 \%$ of them were permanently dependent on it (the lowest value in the district and the third best result among all communes under examination). The commune does not use any quality management system.

With regard to accountability, the commune scored 0.2 point, which is the lowest value in the whole research sample. There is no local press in the commune and the commune office does not publish internal inspection reports 
(the Public Information Bulletin included only a list of inspections without post-inspection documentation). The elections of commune leader are of a plebiscitary character - in the 2014 local government elections, there was only one person (the incumbent commune leader) running for this post. On its official website, the commune office did not publish any property statement (of either councillors or the commune leader) by the statutory deadline ${ }^{63}$. Among the 15 councillors, three of them have higher education.

With respect to openness, the commune scored 1 point because it responded to the CAWI questionnaire within the designated timeframe. The commune did not adopt any resolution concerning the matter of social consultations and did not publish any minutes of commune council sessions for the year 2017. The commune's website or Public Information Bulletin did not include an annual programme of cooperation with non-governmental organizations for the year 2017. Furthermore, during the consultations concerning the preparation of an annual programme of cooperation with non-governmental organizations for the year 2017 none of the organizations submitted any comments.

\section{Geographic and demographic position}

The commune of Walce was established in 1973. It is located in the south-central part of the Opolskie province, in the Krapkowicki district. In 2015 it was inhabited by 5550 people. The commune has a negative population growth. Walce is a rural commune consisting of 9 hamlets and 10 villages $^{64}$. The commune lies within the Opole Conurbation, although it is situated $36 \mathrm{~km}$ from the provincial capital. The commune is crossed by the DK 45 (Opole-Racibórz) national road, but it

63 It should be noted that at present the commune's website contains a complete set of property statements from the previous term of office. The scanned copies of the documents show that they were submitted to the commune office and the supervisory and legal department of the Provincial Office by the required statutory deadline. However, the obligation to publish them on the commune's website by the statutory deadline was not fulfilled. The analysis of the properties of the pdf files of the property statements posted on the commune office website indicates that the scans were made on 27 June 2017, while, according to the adopted analysis method, they should have been made available on the commune's Public Information Bulletin website on 2 June 2017 at the latest. A similar delay was observed in the following year when property statements were published on 14 June 2018.

64 https://opole.stat.gov.pl/vademecum/vademecum_opolskie/portrety_gmin/ krapkowicki/gmina_Walce.pdf (Accessed 10 July 2019). 
is characterized by a low level of public transport connections with the closest urban centers, including Opole ${ }^{65}$.

\section{Economy}

For a long period of time Walce was an agricultural commune with arable land constituting $86 \%$ of its area ${ }^{66}$. However, at the end of the 20th century it lost its predominantly agricultural character in consequence of small and middle-sized farms' turning into intensive production enterprises specializing primarily in pig husbandry (Miczka 2006: 7). In the structure of business entities, $57 \%$ are service enterprises, $39 \%$ belong to the construction and industrial sectors, and $5 \%$ represent agriculture. Out of 327 registered businesses, 317 are micro-enterprises employing up to 9 people. The others employ 10 or more people, with one having over 50 employees. The largest employers include the company Goodmills (production of flour), the company Bischof+Klein (production of industrial foils), and public sector enterprises ${ }^{67}$. In 2015 the share of the unemployed in the working-age population was $4 \%{ }^{68}$. The commune has some attractive environmental and historical characteristics connected with its location in the Odra River Valley. In its territory there are over 70 objects with the status of a historical monument. Despite this, the commune has not developed any tourist infrastructure, although its development strategy identifies potential for the development of tourism based on hiking, bicycling, horse riding, and water sports

\section{Specific features in the material, symbolic, and identity-related areas}

One of the commune's characteristic features in the identity-related dimensions is the strong position of Germans and Silesians, who, on the scale of the commune, constitute a majority of the population. After all, this is a feature constituting one of the criteria for choosing a commune for a case study. The political dimension of the presence of a minority will be presented in more detail in the following sub-chapter. At this point, we want to highlight its social and cultural significance. As it has been mentioned in Chapter 4, the presence of

65 Strategia Rozwoju Gminy Walce, pp. 76-79. http://walce.pl/download/attachment/13298/strategia-rozwoju-gminy-walce-na-lata-2015-2022.pdf (Accessed 10 July 2019).

66 Ibidem: 53.

67 Ibidem: 70-72.

68 https://opole.stat.gov.pl/vademecum/vademecum_opolskie/portrety_gmin/ krapkowicki/gmina_Walce.pdf (Accessed 10 July 2019). 
a minority has a positive influence on the participatory dimension of governance quality. Although Walce's governance quality index is one of the lowest among the communes covered by the research, in terms of participation it had one of the highest places in the ranking. At the institutional level, the presence of the minority manifests itself in the existence of 7 local units of the Social and Cultural Association of Germans in Opole Silesia and enriches the local cultural life. For example, since the beginning of the 1990s Walce has organized the Festival of the German Minority's Choirs and Bands in which numerous choirs and bands from the Opolskie, Śląskie and Dolnośląskie provinces participate (Ogiolda 2018). Walce is also the seat of the Silesian Women's Association established in 1994, whose activities go beyond the territory of the commune. The association's objective is to improve the social and economic position of its members and to strengthen the position of women in the rural environment. The association has 800 members divided into 30 regional groups ${ }^{69}$. Its activities constitute one of the major factors responsible for a high representation (40\%) in the commune council. Brożec, one of the villages in the commune, is the birthplace of Rev. Archbishop Alfons Nossol, one of the most outstanding figures of the regional cultural, academic and social life, as well as an activist in the movement for a rapprochement between Poland and Germany (e.g. in 1989 he celebrated the famous reconciliation mass in Krzyżowa during which Chancellor of the Federal Republic of Germany Helmut Kohl and prime minister of the government of Poland Tadeusz Mazowiecki exchanged the sign of peace). It should be also remembered that it was Stradunia, a village located in the commune of Walce, where the Social and Cultural Association of Germans in Opole Silesia was established in April 1990 (Berlińska 1999: 393).

\section{Political life}

The main characteristic feature of the political life in the commune is the domination of the German minority and the long period of its control of the commune authorities. The data of the State Electoral Commission show that in the years 2002-2018 both the commune council and the post of commune leader were controlled by the representatives of the German Minority Election Committee. It should be noted that in the period 2010-2018, almost the whole commune council, with the exception of just one member, consisted of German minority members (see Table 17). From 2006 to 2018 the post of commune leader was filled by the same person. This political domination was accompanied by a low

69 See the organization's website: http://www.kobiety-silesia.pl/historia.php. 
level of competitiveness. During the four consecutive elections for commune leader held in the years 2002-2014 only in 2010 there were two candidates for this post, and the candidate appointed by the German Minority received $78 \%$ of votes already in the first round of the elections. In the elections held in the years 2002, 2006, and 2014 there was only one candidate who won with the overwhelming support of voters ${ }^{70}$. A measure of the low level of competitiveness in commune council elections is the fact that in 2014 voting was conducted in two out of fifteen constituencies, which means that in thirteen constituencies German minority candidates had no rivals and became councillors without voting ${ }^{71}$.

Thus, for many years the commune has been controlled by the same political group and has not had any opposition capable of challenging this domination. There are no structures of political parties in the commune. The majority of nongovernmental organizations are connected personally or institutionally with the Social and Cultural Association of Germans in Opole Silesia. Consequently, civic society organizations cannot be expected to generate an alternative to the group governing the commune.

An analysis of the minutes of commune council sessions for the year 2016 shows that the commune leader enjoys complete support of the council and all proposed resolutions are passed, usually unanimously. Out of the 68 resolutions passed in 2016, only one resolution received one vote against it. The minutes allow the conclusion that the council is rather passive as a controlling body that initiates debates. During the eight sessions held in 2016 councillors asked questions or proposed motions on 16 occasions. Eight councillors did not speak during sessions at all, and three councillors took the floor just once. It was a period of a high level of unanimity, although it should be noted that in the pre-election period in 2018 there appeared cracks on this harmonious picture. During the session held in February 2018 one of the German Minority councillors accused the commune leader of failing to notify

70 In 2002 the candidate received 1152 "in favour" votes and 239 "against" votes; in 2006 1076 "in favor" votes and 133 "against" votes; in 2014 - 1122 "in favor" votes and 273 "against" votes (data of the State Electoral Commission).

71 This means that in 2014 there were only 684 people entitled to vote for candidates for commune council members in two constituencies; 305 of them cast their votes. Data for the years from 2002 show that it is a permanent feature of local council elections in the commune of Walce (with the exception of 2010 when the "Silesian Village" Voters Election Committee appointed its candidates in six out of the seven constituencies). In 2002 voting was not conducted in three out of the eight constituencies, and in 2006 - in four out of the seven constituencies. 
the councillors of the activities of the commune authorities and to attract new investors (Kliszewski 2018). During the subsequent session the same councillor, supported by two others, declared the establishment of an Independent Councillors' Club and proposed a motion to withdraw the draft resolution on a change to the commune budget because, in his opinion, he had not been able to become acquainted with it. He claimed that such circumstances constituted a breach of Article 20 of the Local Government Act, pursuant to which a notification of the convening of a council session is accompanied by an agenda and draft resolutions. Eventually 12 councillors passed the resolution on a change to the commune budget. The councillor also asked why during the past 12 years no tendering procedures had been announced for the maintenance of roads and squares in winter and what amounts had been paid to the enterprises performing that task in the years 2007-2017 (Smolarz 2018). Thus, there appear some signs of controlling activities and critical opinions about the commune leader, but it seems that it is not a permanent trend in local politics ${ }^{72}$, but rather an attempt to emphasize one's presence in the commune council or an internal conflict within the local German Minority structures, which is also proved by the lack of support for the incumbent commune leader in the primary elections held in 2018 (more on this topic in the further part of the chapter).

\section{Attempt to explain the governance quality profile}

Attempting to explain Walce's low governance quality index, we should note that the commune scored the fewest points in the sub-indexes of accountability and openness (jointly 1.2 points), which raises the question about factors responsible for this. There are two basic and complementary directions towards a reliable explanation. One of them is the long lasting domination of one political group in the local governing bodies, which entails the necessity of taking into consideration the issue of multiculturalism and its impact on the quality of governance in the commune under examination. The other is the specific character of the local community and its relations with the commune authorities.

Walce is a multicultural commune inhabited by people identifying themselves as Germans, Poles or Silesians. Nevertheless, at the level of local political

72 It should be emphasized that a review of the minutes of the commune council sessions for the year 2019 shows that the March and May session lasted about 20 minutes. 
Tab. 17: The structure of the council of the commune of Walce during the past four terms of office in terms of the number of seats held by the particular groupings

\begin{tabular}{lllll}
\hline $\begin{array}{l}\text { Name of election } \\
\text { committee }\end{array}$ & $2002-2006$ & 2006-2010 & 2010-2014 & 2014-2018 \\
\hline $\begin{array}{l}\text { German Minority } \\
\begin{array}{l}\text { The Walce Village } \\
\text { Council }\end{array}\end{array}$ & $\underline{9}$ & $\underline{11}$ & $\underline{14}$ & $\underline{14}$ \\
$\begin{array}{l}\text { Education Sector } \\
\text { Employees }\end{array}$ & 1 & & & \\
$\begin{array}{l}\text { Supporters of Leszek } \\
\text { Kłosowski }\end{array}$ & 1 & 1 & \\
$\begin{array}{l}\text { Supporters of Zygfryd } \\
\text { Machoń }\end{array}$ & 1 & & & \\
$\begin{array}{l}\text { The Walce Village Sports } \\
\text { Club }\end{array}$ & & 3 & & \\
$\begin{array}{l}\text { The Silesian Village } \\
\text { RdO }\end{array}$ & & & 1 \\
\hline
\end{tabular}

Source: the authors' own work based on the data from the National Electoral Commission.

institutions, the German Minority has dominated the commune authorities for many years. The organizations of Silesian autonomists do not have any local structures in the Walce commune. This is a situation in which one national group has managed to monopolize power and base local politics on a high level of unanimity (possibly coerced by peer pressure) and local level cooperation. The political power of the German Minority, which constitutes a majority in Walce, is based, among other things, on its high organizational potential anchored in the local units of the Social and Cultural Association of Germans in Opole Silesia. It should be remembered that the Association, being a foundation for the German minority's political activity on the provincial scale, is one of the strongest non-governmental organizations in the region. Therefore, its local units in the commune of Walce are parts of a larger, well organized and financed structure ${ }^{73}$. Moreover, while particular election committees competing

73 Local units (so-called German friendship circles) are established by the main board of the Social and Cultural Association of Germans in Opole Silesia, but they are subordinate to a local commune board of the Association, which functions as a middle-man between the central authorities of the Association and its local units. On 
against the German Minority were active only in the pre-election period, the Association functions in the commune on a permanent basis as a driving force for social and cultural life (Interview 4). The local units of the Social and Cultural Association of Germans in Opole Silesia embrace active people interested in the life of their villages and commune, being simultaneously grassroots entities anointing candidates for councillors (Interview 5). The position of the German Minority in Walce may also be strengthened by the fact that it is one of the strongest groupings in the council of the Krapkowicki district and governed the district in the years 2002-2010 (Szczerbaniewicz 2011). Another important factor attracted the attention of one of the journalists of the newspaper published in the Krapkowicki district. In her opinion, critical comments in the discussion on the role of the German Minority are very rare and neutral journalists "find it very difficult to present negative comments on the environment of the minority" (Szczerbaniewicz 2015). The result is a situation in which the German Minority authorities receive nothing but praise, which distorts the true picture of this social group. As a journalist of a local newspaper published in the district where the German Minority enjoys considerable political influence, she emphasizes that there are people who complain in secret about the discrimination against Poles (Ibidem). Thus, we have a situation in which the local public opinion exerts pressure on eliminating criticism targeted at the German Minority authorities. It should also be noted that the German Minority peer tribunal received demands that the members from Walce and two other communes who ran for seats in the council from competitive election committees in the 2014 local government elections be punished for their actions $^{74}$. It shows that the German Minority is ready to prevent the appearance of any alternative political group among the German population. Commenting on this fact, Sebastian Fikus, a researcher specializing in the issues related to the German minority in Opole Silesia indicated that its elites follow an anti-intellectual strategy aimed at neutralizing the influence of the burgeoning middleclass groups within the German minority. It is to allow them to maintain their

the provincial scale, it is a three-level integrated structure whose governing boards are selected on a bottom-up basis by delegates. See: http://skgd.pl/o-nas/statut/ (Accessed 1 July 2019).

74 The peer tribunal is one of the bodies of the Social and Cultural Association of Germans in Opole Silesia; its competencies are set forth in the Statute of the Association. The tribunal may punish a member with a warning, temporary suspension of a member's rights (for up to one year) or dismissal from the Association. See: http://skgd.pl/o-nas/ statut/ (Accessed 1 July 2019). 
power anchored in folklore, hence their concentration on supporting initiatives of a folklore, popular, or light-entertainment character. Simultaneously, the expectations of the middle class are ignored and German minority activists who change their political affiliations and try to address people's new needs and expectations are being ostracized (Fikus 2015).

Thus, the commune is governed by a well-organized national group deeply rooted in local institutions and characterized by a strong sense of cultural identity. It seems that it is an important factor determining a low level of political competitiveness in the commune, that is a small number of, or no, rivals in commune council or commune leader elections, which may result from the conviction that chances for winning are low in light of the strength of the German minority. The absence of recognizable political competitors among people declaring Polish nationality is accompanied by the spirit of unanimity and conformism among the German minority, which reduces the risk of internal political rivalry ${ }^{75}$. Consequently, we have a situation in which truly democratic elections are impossible and dissatisfied voters are not able to reject the local political elite. The only candidate for commune leader in the 2018 elections commented on this state of affairs, "As far as other candidates for commune leader are concerned, I haven't heard of any, and it's a pity. For a long time Walce hasn't had true elections where people could choose from more than one candidate" (Szczerbaniewicz 2018).

What requires explanation in the context above is the lack of a political representation of people declaring Polish nationality. It is possible to distinguish a few overlapping factors responsible for this. The German minority has been very active in the commune since the beginning of 1990s when it created and developed a basis for social organizations to form a strong platform of defence for the minority's interests. It was mobilized by the awareness that in a democratic system, a minority has a chance to make decisions important for it at least at the level of commune politics. It is also necessary to take into consideration the fact that despite the present appearance and politicization of Silesian identity, in that period the Social and Cultural Association of Germans in Opole Silesia was a natural political representation for many Silesians. Thus, it represented both

75 It should be noted that in the 2018 local government elections, two constituencies had candidates for commune councillors who belonged to the German Minority, but represented election committees competitive with that of the German Minority. After being elected, they joined the German minority club in the commune council, thus ensuring $100 \%$ of the seats in the council for the German minority (Interview 4). 
those who declared openly to be German and those who preferred to define themselves as Silesians (but all of them had the same origin and a majority of them had two passports). In Walce, these groups constituted (and continue to constitute) a majority. Thus, the political domination of the German minority is the heritage of its organizational structures and influence developed already in the 1990s. Poles did not have such a vigorous organizational network and were a minority in Walce, hence it was difficult for them to overcome the real and imaginary barrier preventing their entry to the local political institutions. Furthermore, the divisions and antagonisms visible at the beginning of the 1990s gradually disappeared. Many Poles regarded the structures of the German minority as their own political representation and even ran for seats in the council from its election committees. Additionally, the present voting system applicable to small communes with single-mandate constituencies is advantageous for these groups that have an arithmetic majority at the level of a constituency and encourages political consolidation around one candidate (Interview 5).

Nevertheless, it should be stressed that the local ruling elite has internal accountability mechanisms, which was proved in the 2018 elections for commune leader when the incumbent leader holding office for 12 years did not receive recommendation from the local structures of the German Minority as its candidate in the next elections. The German Minority appointed its candidate for commune leader in a two-stage procedure. At the first stage voting was carried out in the seven local units, five of which supported the incumbent commune leader. It should be noted, however, that members voted in an open ballot, which, in such a small community, may have helped the incumbent leader. Subsequently, in May 2018 the Commune Convention of the Social and Cultural Association of Germans appointed the manager of the Commune Culture Centre as its candidate. He received eight of the eleven votes. The voting was preceded by the presentation of election programs, but the Convention was able to become familiar only with the programme of the eventually successful candidate because the incumbent commune leader failed to appear at the meeting. The chairperson of the commune board of the Association declared that he was not surprised with the result of the voting because for some time inhabitants and the local units of the Association had been complaining about the leader's style of management and expecting a new approach to matters important for the commune (Szczerbaniewicz: 2018a).

During the three years preceding the aforementioned election the new and only candidate for commune leader in the 2018 elections had become known as an important social activist and local leader holding the post of manager of the Commune Culture Centre. Besides managing the Commune Culture Centre, he 
was also director of a local brass band, head of a local instrumental ensemble, member of the Opole Philharmonic Orchestra, founder of a football school, and member of a voluntary fire service unit. As manager of the Commune Culture Centre, he revived local cultural life, implementing a number of initiatives and winning the title of the friendliest official in a poll organized by a local district newspaper in 2017. In one of his interviews, he said that it was inhabitants that were encouraging him to run for the post of commune leader (Szczerbaniewicz 2018b). The case of the primary elections held by the German Minority in 2018 shows that, although in the local political system there are no competitive groups, there are some bottom-up mechanisms allowing the replacement of leaders in the ruling national group. Such a mechanism was launched in a situation of dissatisfaction with the rule of the commune leader and the simultaneous appearance of a new leader capable of winning the support of the local community. Withdrawing support for the incumbent commune leader during his third term of office (2014-2018), i.e. the period which was evaluated in the study, indicates indirectly that our assessment corresponds to the opinions of commune inhabitants. For example, the survey conducted among inhabitants within the scope of the commune's development strategy for the years 2015-2022 ${ }^{76}$, in which participants were asked to assess the execution of public tasks, shows that $41 \%$ of them assessed such execution as bad or very bad, $26 \%$ - as neutral, and $33 \%$ - as good or very good. When asked about the quality of life in the commune, $57 \%$ of respondents assessed it as average, $29 \%$ - as good, $7 \%$ - as very good, and only $7 \%$ - as very bad. On the basis of these unrepresentative data, it is possible to read a tendency according to which an assessment of the general quality of life in the commune is better than an assessment of the commune authorities, which met with a higher level of discontent ${ }^{77}$.

The issue of accountability in Walce should be complemented by reference to the issues of the local media and the publication of property statements. Although in the commune there are no media critical of the local authorities, this function is fulfilled by the district press which published articles showing irregularities in the commune office. The most significant example with far-reaching consequences is the matter of the director of the Commune Culture Centre which appeared on the front page of the "Tygodnik Krapkowicki" weekly

76 It should be emphasized, however, that the questionnaire was filled in by 14 inhabitants only, thus, its results are highly unrepresentative.

$77 \mathrm{http} / /$ walce.pl/download/attachment/13298/strategia-rozwoju-gminy-walce-nalata-2015-2022.pdf (Accessed 10 July 2019). 
in 2014. From 2008 the director of the institution had been simultaneously a member of the management board in a private enterprise, which constituted a breach of the so-called Anti-corruption Act of $1997^{78}$. It is worth noting that the director every year declared such a fact in his property statement and when asked about the combination of such functions, he claimed not being familiar with the provisions of the Anti-corruption Act. Meanwhile, the commune leader, who was responsible for checking property statements, said in an announcement for the press that his deputy had dealt with property statements. It means that for many years the director of the Commune Culture Centre was breaking the law and was declaring it in his property statements, while his superior was doing nothing about it. This case shows that the procedure of publishing property statements does not guarantee compliance with anti-corruption standards, but creates certain conditions for initiating control mechanisms, if they exist. In this case, it was the local district media which revealed irregularities and forced the commune leader to act accordingly. Eventually, the director was dismissed disciplinarily and the commune announced a competition for a new director. The new director soon became a local leader and in 2018 - a new commune leader ('Dyrektor' 2014).

The matter described above also allows the conclusion that the local media are interested in the property statements of local public officials and use them in their everyday work. It should be remembered that one of the accountability indexes used in this research is the timely publication of property statements, which we regard as the index of "accountability culture" rather than true accountability. Under this index, the analyzed commune did not score any points, but it should be noted that the role of property statements in the commune of Walce is not deprived of importance and thanks to the media, they have an important controlling function to fulfil. A case in point is not only the matter of the Commune Culture Centre director but also a review of published property statements conducted by the media operating in the district. In April 2015, i.e. at the beginning of the new council's term of office, the "Tygodnik Krapkowicki” weekly published photographs of all councillors and lists of their property such as savings, real property, and movable property worth over 10,000 zlotys as well as debts ('Rolnicy' 2015). In December 2015 the paper published another article in which, on the basis of documents from a commune council session, it referred to the analysis of property statements carried out by the tax

78 The act on restrictions on business activities conducted by persons holding public offices of 21 August 1997 (Journal of Laws of 1997, no. 106, item 679). 
office. In consequence of the analysis, the tax office suspected irregularities in the statements of two councillors (Szczerbaniewicz 2015a). It means that although the commune did not meet the accountability culture criteria related to the index, property statements themselves (after their publication) were monitored by the local media capable of disciplining the local authorities.

Another issue is the commune's low level of openness which should be considered in the context of specific relations among the local authorities and the inhabitants of the commune organized in local social integration institutions.

As it has been mentioned earlier, the commune is characterized by a high level of social participation which is accompanied by cooperation between the authorities and inhabitants through the agency of such institutions as the local units of the German Minority, voluntary fire service units, village leaders and councils, associations and parishes. The members of particular institutions' governing bodies often fulfil a few functions at the same time, e.g. a councillor can be a member of a parish council or a voluntary fire service unit. Similarly to other small communes, the number of active members of local organizations in Walce is several dozen. The same persons are cultural life promoters and decision makers in local politics (Interview 5). The characteristic feature of Walce is the protective (formal or informal) supervision of the Social and Cultural Association of Germans in Opole Silesia over the majority of such local groups.

It should be emphasized that as early as 1997 the commune joined the Rural Revival Programme of the Opolskie province. Since that time the particular villages of the commune have been getting involved in the programme within which so-called revival groups consisting of local leaders representing various environments are established. At the first stage of the programme revival plans were developed for the particular villages and various training events and seminars were organized. Subsequently, every year the villages from the Walce commune participated in competitions for the most beautiful village in the Opolskie province and won high positions in final ranking ('Gmina' 2017). For example, in 2016 the village of Stradunia was awarded the title of the most beautiful village in the province. This success was the effect of the grass-roots activities of its inhabitants, who established the Association for the Development of the Stradunia Village. Its head is the village leader, but cooperation between the association and the commune leader is also of considerable importance (Dimitrow 2016).

The role of the village leader deserves special attention because in the commune of Walce village leaders are not a façade institution deprived of influence and competences, but fulfil the function of true local leaders. They are responsible 
for small projects financed from village funds, cooperate with village councils, voluntary fire service units, parishes, waste disposal businesses, and the commune German minority board (Malkusz 2014a; 2014b). In one of the interviews, the village leader emphasizes the special role of village leaders who "understand the idea of a village fund". This is proved by the fact that $97 \%$ of the available resources were used in 2016 (Marx 2017). Village leader elections are also in the centre of attention of the local media, which reported their course in 2015. Such reports included information on the voting process as well as the achievement of particular villages where elections were being held. Village leader elections are usually non-competitive (without rivals) and incumbent leaders are usually elected for another term of office with a great support of voters (over $90 \%$ ). Village leader and council elections constitute an important event in the life of a local community. For example, in 201588 voters participated in the elections for the Walce village leader and 86 of them supported the incumbent leader, whose success was received with an ovation ('Jest' 2015; 'Owacje' 2015).

The commune is dominated by a spirit of cooperation anchored in mutually related institutions constituting forums for the articulation of interests of particular social groups and everyday communication with the commune authorities. The village leaders, village councils, voluntary fire service units ${ }^{79}$, local units of the German minority and their representatives in the commune council ${ }^{80}$ or the commune office structures are in close, also informal, relations. In such conditions, from the perspective of the local community, typical solutions aimed at strengthening openness such as a resolution on social consultations, the publishing of commune council sessions or access to an annual programme of cooperation with non-governmental organizations may be defined as inessential because their substitute is a small distance between active village communities

79 It is worth noting that voluntary fire service units have been functioning in the particular villages of the commune for over a hundred years. Despite changes in the political borders in 1945, the local population maintained its institutions, which constitute a framework for social integration and identification with the local community (Miczka 2006: 8).

80 In a survey conducted among the councillors for the purposes of the Development Strategy of the Walce Commune for the years 2015-2022, analyzing the various areas of the commune's functioning, the councillors gave the highest marks to their cooperation with the commune office (Strategia Rozwoju Gminy Walce: 102). Of course, it can be supposed that such positive opinions are connected with the councillors' and the commune leader's membership in the German minority monopolizing the local authorities. 
and formal governance institutions. It should be stressed that such a small distance is not a result of the size of the population, but rather its organizational vitality. Thus, paradoxically, Walce's high participation index may explain the deficit in the selected sub-indexes of openness.

In summary, the picture of the quality of governance in the commune of Walce is not as unambiguous as it could be expected on the basis of the preliminary quantitative analysis. The commune's low position in the ranking is caused first of all by the dimensions of accountability and openness. Nevertheless, its score in the dimension of participation was very high. An explanation of this specific situation requires taking into consideration the commune's multiculturalism and the unique position of the German minority, which for many years has been monopolizing power in the commune, being simultaneously responsible for the high level of local participation. From the perspective of governance quality, the presence of a national minority which, in the commune under examination, constitutes a percentage of the population high enough to allow it to dominate the local political scene, is of a both ambivalent and paradoxical character. A long-lasting monopoly of one political group favors the weakening of some accountability (and maybe also openness) mechanisms, but the conducted analysis shows that it does not mean that there is no possibility of dismissing local leaders from their office. Simultaneously, such political monopoly is determined by the German minority's organizational resources and high level of participation, which allow it to maintain power in the commune. Thus, the high level of participation may facilitate long-lasting domination of one political group, which, subsequently, increases its mobilization potential, using local institutions. At the same time a spirit of participation and cooperation within local power structures generates a sense of access to inputs of a local political system, which replaces more formalized solutions aimed at ensuring the openness of commune authorities. Therefore, in this particular case, multiculturalism is not a factor unidirectionally influencing the holistic understanding of governance quality, but rather a state which can generate positive or negative phenomena, depending on the various dimensions of the quality of governance.

\section{Paczków}

\section{Governance quality profile}

The conducted quantitative analysis indicates that the commune of Paczków holds one of the highest positions on the governance quality scale with 15.32 points. It is simultaneously a commune with a low ethnic fractionalization index. 
Paczków scored 2.6 points in the sub-index of participation. The commune has 18 active non-governmental organizations ${ }^{81}$, including public benefit entities. Funds donated to public benefit organizations under the $1 \%$ mechanism amount to 0.92 zlotys per inhabitant (12,800 zlotys in total). The percentage of voters supporting voters' election committees is $81 \%$. The number of people using the services of the commune public library is relatively high: 173 per 1000 inhabitants (the average for the Nyski district is 120). The average mark in junior secondary school social science and history examination is $51 \%$.

With respect to equality, the commune scored 3.5 points. Among the 15 councillors there are 8 women (the average for the 60 commune councils covered by the research is $30 \%$ ), and women held 2 of the 4 managerial positions distinguished in the research (commune secretary and social assistance centre manager). The commune has a youth council and a senior citizens council. The poverty risk index as assessed by the Regional Social Policy Centre was relatively high and equaled 0.504 (the lowest value for a commune on a scale from 0 to 1 meaning the highest level of poverty risk was 0.482 ).

With respect to efficiency, the commune had a low score (1.85 points), which was caused by relatively low capital expenditures per inhabitant in 2015 (130.75 zlotys) and a low level of the commune's own income in 2015 (the lowest value among the Nyski district communes - 1,295.99 zlotys). In 2014 current expenditures on public administration per inhabitant amounted to 294.21 zlotys. Among all beneficiaries of social assistance, $34 \%$ were permanently dependent on it (the commune had the best score in the district with 0.66 point). The commune does not use any of the indicated quality management systems. This criterion was fulfilled by only 3 of the 60 communes covered by the research.

With respect to accountability, the commune scored 3.32 points. Established in 2009, Paczków24 is a popular website in the commune. Its founder was an opposition councillor during the term 2010-2014 and a candidate for mayor in 2014. The website includes a tab called "Local Government" where local political events are described (e.g. town council sessions) and commented. Particular articles are followed by numerous critical comments. The website has 5000-6000 visits per day, and inhabitants propose on average 10 issues per week to be investigated by its journalists (Interview 6). The commune's Public Information Bulletin website contains a list of inspections conducted in the years 2015-2016

81 Although the website of the Paczków Town Office lists 35 non-governmental organizations (including 6 voluntary fire service units and 5 village sports clubs, it is important to remember the used methodology of counting such organizations. 
(14 inspections in total), but post-inspection documentation (so-called postinspection reports) is published only for inspections conducted by the Regional Accounting Chamber. During the local government elections in 2014 there were 5 candidates for mayor - these elections ended the long period from 1998 to 2014 when the post of mayor was held by one person ${ }^{82}$. As far as property statements are concerned, on 2 June 2017 the commune's Public Information Bulletin contained the mayor's property statement only. Among the 15 councillors, four of them have higher education.

With respect to openness, the commune scored 4 points. It fulfilled its obligation to provide public information, answering the questionnaire in a timely manner. The commune has adopted a special resolution regulating the matter of social consultations. Its website contains a current programme of cooperation with non-governmental organizations and minutes of commune council sessions for the year 2017. However, the process of consultation concerning this programme was assessed as ineffective: no non-governmental organizations submitted comments on the programme.

\section{Geographic and demographic position}

Paczków is an urban-rural commune located in the south-western part of the Opolskie province, in the Nyski district. The commune consists of the town of Paczków and 12 villages, covers the area of $80 \mathrm{~km}^{2}$, and in 2015 had approximately 13,000 inhabitants, with $60 \%$ of them living in Paczków. The commune is characterized by a high population density of 162 persons per $\mathrm{km}^{2}$, which gives it the 10th place in the province ${ }^{83}$. The commune is located on the periphery of the province. It borders the Dolnośląskie province to the west and the Czech Republic to the south. It should be noted that Paczków is peripheral with respect to both the provincial capital (the distance from Paczków to Opole is $80 \mathrm{~km}$; the distance to Wrocław, who is a much more attractive migration destination, is also approximately $80 \mathrm{~km}$ ) and its location at the border between Poland and the Czech Republic. The peripheral location of the town was one of the factors determining its selection as a subject matter of a discussion at a session of the Parliamentary Committee of the Local Government and Regional Policy. The town lies on the Nysa Kłodzka River between Otmuchowskie Lake and Paczkowskie Lake, near the Kłodzka Valley and the Golden Mountains. The commune is crossed by the

82 It should be emphasized that the incumbent mayor did not run for the office in 2014.

83 https://opole.stat.gov.pl/vademecum/vademecum_opolskie/portrety_gmin/nyski/ gmina_Paczkow.pdf (Accessed 12 September 2018). 
Opole-Kłodzko national road no. 46. Because of its location and rich history, the commune has some potential for the development of tourism ${ }^{84}$. The commune is a member of the Polish Communes' Association of the Pradziad Euroregion; its cross-border partner is the Czech town of Jawornik. Cooperation between the partners includes, among other things, a project called the Virtual Eye of Culture in the Paczków-Jawornik Borderland ${ }^{85}$.

\section{Economy}

After World War II the former German industrial enterprises located in the commune were nationalized ${ }^{86}$ and the new state owner continued their development. A considerable part of the population was employed in a few industrial plants, which were the largest employers in the commune. According to the data for the year 1982 the five largest industrial enterprises employed the following numbers of people: the Paczków Furniture Factory (750), the "Famad" Paczków Plant of the Forestry Machinery Industry (340), the "Zremb" Repairs and Production Enterprise (320), the Opole Furniture Factory no. 5 in Paczków (300), the "Pollena" Paczków Household Chemistry Plant (295) (Białek 1983: 44). The political system transformation caused the privatization and bankruptcy of many businesses, which resulted in the problem of structural unemployment. According to the data for November 1994, among all communes of the Opolskie province, Paczków had the highest rate of unemployment (18.7 \%; Dąbrowski 1996: 76) ${ }^{87}$. The Local Revitalization Plan for the Town of Paczków until 2023 indicates that unemployment is the basic social problem in the commune. In 2004 the rate of unemployment in the whole Nyski district was $31.9 \%$ (20 \% in the Opolskie province), while in 2014 it was $16.8 \%$ (11.8\% in the Opolskie province). Thus, the commune was located in the district which, together with the Brzeski district, was characterized by the highest rate of unemployment in the

84 https://paczkow.pl/download/attachment/4961/lokalny-program-rewitalizacji-miastapaczkow-do-roku-2023.pdf (Accessed 12 September 2018).

85 The project's website: http://wokppj.eu/19/8/aktualnosci.html.

86 The industrial sector started to develop in Paczków as early as the 18th century with the establishment of a factory manufacturing candles and wax products. The 19th century witnessed the construction of enterprises manufacturing fire fighting products and extinguishers, matches, as well as soap. The most important business was a factory owned by the Schneider family and specializing in the manufacture of drawing equipment that was exported to many countries in Europe and both Americas (Głuszczak 2001: 27).

87 Dąbrowski K., Paczków - szkice z dziejów miasta, Opole 1996, p. 76. 
province $^{88}$. In 2015 the share of the unemployed in the total number of workingage population was $8.5 \%$ (6.8 \% in the district), which shows a falling trend characteristic of the whole country.

According to the data for $2004,39.3 \%$ of the workforce were employed in the industrial and construction sectors, $37.1 \%$ in the service sector, and $23.6 \%$ in agriculture ${ }^{89}$. In 2014 the commune's entrepreneurship index was $127 / 1000$, while that for the whole province equaled 100/1000. A considerable part of enterprises (36\%) represented the commercial and automotive repairs sectors, the construction sector (18\%), and the industrial processing sector (9\%). Among all business entities, $96 \%$ were micro-enterprises ${ }^{90}$. Besides the Town Office, the group of large employers includes Famad, a factory producing industrial machinery and equipment (80 employees), and Wienerberger, the world's leader in the manufacture of bricks, which had bought the local brickyard in 2016. Simultaneously, it should be noted that despite its tourist attractiveness, the commune does not have a single accommodation facility with more than 10 beds $^{91}$.

\section{Specific features in the material, symbolic, and identity-related areas}

The long history of Paczków as well as its urban and environmental advantages should be regarded as the town's specific features present in the identity of its inhabitants. The history of Paczków goes back to 1254 when a trading post was established under a location privilege issued by the bishop of Wrocław ${ }^{92}$.

88 https://paczkow.pl/download/attachment/4961/lokalny-program-rewitalizacji-miastapaczkow-do-roku-2023.pdf (Accessed 12 September 2018).

89 In the Local Development Plan for the Years 2004-2013 which includes the aforementioned employment structure data Paczków is presented as an agricultural commune, although the employment structure contradicts this description. This shows the quality of some strategic documents prepared for communes in the period before accession to the European Union. See: http://www.archiwum.paczkow.pl/files/Plan_Rozwoju_ Lokalnego_Gminy_Paczkow_2004-2013.pdf (Accessed 14 September 2018).

90 https://paczkow.pl/download/attachment/4961/lokalny-program-rewitalizacji-miastapaczkow-do-roku-2023.pdf (Accessed 12 September 2018).

91 https://opole.stat.gov.pl/vademecum/vademecum_opolskie/portrety_gmin/nyski/ gmina_Paczkow.pdf (Accessed 12 September 2018).

92 It is worth mentioning that according to a local legend, Paczków was established as early as in the 4th century by the Roman leader Lucca, who was coming through the territory of contemporary Paczków from a war expedition. Subsequently in the year 500 the town was allegedly destroyed by Hungarians. It is only one of many legends from the Paczków-Jawornik borderland. They were written down by Eugeniusz Mazurkiewicz, see (Mazurkiewicz 2017b). 
According to historical records, the Town Council was established allegedly in 1345 , but for a long period of time it was subordinate to the mayor who was a liegeman of the bishops of Wrockaw (Steinborn 1982: 128). This medieval heritage is still present in inhabitants' everyday life, because the town still has its 14th century defence wall surrounding the centre and three towers constituting in the past starting points in journeys towards Kłodzko, Nysa and Wrocław. This is why the town is called Polish Carcassone, and because of its historical architecture, it has the status of a monument of history ${ }^{93}$. Visible in the urban space, this centuries-old history appears to be a source of inhabitants' pride and an important element of local identity. Identification with Paczków as "a pearl of history" was to be built already after World War II when the town's schools taught the history of Paczków and the region as an obligatory subject (Szypowska 1965: 5) ${ }^{94}$. For over 30 years the town's public library has organized the Paczków History Competition, which is a form of regional education for the town's school age inhabitants. The competition is addressed to young people from the town and commune ('Dużo' 2017).

An example of an activity aimed at building and developing identification with a local homeland is also the competition for the best poem about Paczków organized every year from 1997 by the town's Centre of Culture and Recreation. The competition was open for both young people and adults. Henryk Romańczyk, who for many years worked as director of the Paczków Centre of Culture and Recreation, writes that the competition concerns "the same and unchanging reality in which we live and which we create together with others, where people's thoughts committed to paper focus on just one theme: Paczków, my home town..."95. There were 13 editions of the competition and its effect was 5 volumes of poetry about Paczków. Another similar initiative is a competition for limericks about Paczków organized by the "Pegasus" Association. It is addressed to "the lovers of Paczków" and aims to develop local patriotism, interest in history, and artistic talents ${ }^{96}$.

93 For this reason, the National Heritage Institute in cooperation with the Polish Television Culture produced a documentary about Paczków (Pomnik Historii odc. 14 - Paczków 2016): https://www.youtube.com/watch?v=taGS8D7QuKk\&feature=share\&list=PL9W zZUVLsKgO-MmuixQJWJgWJg6y6dHPf\&index=14 (Accessed 18 September 2018).

94 One can only guess that it must have been a part of the propaganda justifying the appropriation of the so-called recovered territories by new communist authorities.

95 For example, the fifth edition of the competition held in 2002 attracted 52 authors who submitted 72 literary works. ('Paczków' 2002:. 5).

96 The website dedicated to the competition: http://pegaz.org.pl/wydarzenia/limeryk/. 


\section{Political life}

During the years 1998-2014 the commune was governed by the same mayor who decided not to run for the office in the 2014 elections. It is rather difficult to assess his terms of office unambiguously. An interview conducted with a representative of the new town office authorities indicates that it was a period of stagnation during which none of the 12 villages was equipped with a sewer system and there remained a number of households without access to a sewer system in the town itself. The commune has to repay debts incurred by the previous authorities, which also wasted many years without preparing any areas for business development purposes. At present the commune authorities are trying to make up for the lost time, which should be understood as dragging the commune from the state of backwardness, mainly by the intensive utilization of available EU funds (Interview 7). A similar image is presented by a local government activist from the commune according to whom the previous mayor's terms of office were wasted. For example, his effectiveness in acquiring EU funds was much worse than that of the new mayor. The former mayor's remaining in office for a long period of time resulted from the fact that he was generally liked by inhabitants, had numerous connections, and functioned in the capacity of an employer for many people, which provided him with a considerable support base (Interview 8). It should be noted, however, that in the 2014 local government elections, one of the 5 candidates running for the office of mayor was the former mayor's deputy, who symbolized the continuity of the previous style of government and offered voters "peaceful, reasonable development, without a revolution" (Strauchman 2014). That candidate took part in the second round of the elections, but lost, scoring $42 \%$ of votes (with the voter turnout of $41 \%$ ), which indicates that still a considerable group of active voters had positive opinions about the previous mayor and his many terms of office. The winner of the 2014 elections had run for the office of mayor in 2010 as candidate of the Civic Platform. He had lost with the incumbent mayor in the second round, getting $43 \%$ of votes, with the voter turnout of $40 \%$. He won eventually in the 2014 elections, when he was appointed by a voters' election committee. In the years 2006-2014 the new mayor was the sole representative of the commune of Paczków in the Nyski district council. It means that at present the commune has no representation at the district level, while the neighboring commune of Otmuchów has five district councillors. Such a low level of representation in the district council weakens the commune's position in such matters as expenditures on road maintenance, cultural policy (e.g. the district office's plan to shut down 
the Visual Artists' House located in the Paczków market square), or health care ('Bez radnego' 2015).

The commune's local politics is characterized by a large number of political groupings in the subsequent town councils and a low level of councillors' dependency on political parties. The table 18 shows that since 200219 different organizations or voters' committees have had their representatives in the town council. The average number of political groupings in the town council during the past four terms of office is 7 . The majority of councillors are not related to political parties. The average for the past terms of office is 4.5 councillors from party-based committees in the council consisting of 14 members. This indicates a high level of political competition, a high level of local political activity, representations of various environments and interest groups, as well as political fragmentation.

During the term of office 2014-2018 12 out of the 15 members are new councillors, which means that there had been a replacement of the local political elite. The council includes 2 councillors representing a political party. An analysis of the council session minutes for 2016 shows that the mayor enjoys considerable support among the councillors, although officially, just 5 of them represent his election committee. A measure of this support is voting on subsequent resolutions: out of the 106 resolutions passed in 2016, 102 were passed unanimously. In the remaining cases, one or two councillors abstained from voting. The most controversial issue was the vote on the resolution increasing the mayor's salary, when 3 councillors abstained from voting ${ }^{97}$. According to the minutes, council sessions are conducted without interruptions and in an atmosphere of mutual respect. With the exceptions specified below, the mayor usually adopts a conciliatory attitude towards the councillors and an inclusive attitude towards groups interested in particular decisions. A case in point is the risk of the liquidation of the secondary school when the mayor said that, "the mayor, councillors, and teachers will have to do our best and find a solution"98. The councillors ask questions, but their activity is diversified and rarely critical. In their statements, they submit requests and draw attention to concrete problems requiring the authorities' reaction. Altogether there were 75 questions asked and comments made during 12 sessions, with 16 statements made by inhabitants or village leaders participating in them. Three councillors did not take the floor a single time, and two councillors presented their opinions publicly only once. The most active councillor, who does not belong to the incumbent mayor's

97 https://paczkow.bip.net.pl/?a=5962 (Accessed 10 August 2018).

98 https://paczkow.bip.net.pl/?a=5964 (Accessed 10 August 2018). 
election committee, spoke on 16 occasions. The second most active councillor, who represents the mayor's voters' election committee, took the floor during 8 council sessions. An analysis of the minutes shows that the mayor has no opposition and he himself is capable of persuading the councillor to accept his point of view and seems to be the main driving force for the process of governance in the commune. The strength of his influence can be measured by the fact that in the 2018 local government elections 10 councillors were running for seats in the council from his election committee, which means that the mayor had doubled the number of his supporters in the council during the term of office (Interview 7). Nevertheless, it should be noted that the mayor is also regarded as a man with domination tendencies (which is not reflected in the session minutes), who has managed to subordinate the council to himself (Interview 9). Thus, we can talk about local politics in which the mayor is the central driving force. He has managed to build a coalition of councillors supporting his vision of the commune's development and to start implementing this vision, taking advantage of available instruments. At the same time, the mayor's attitude of readiness for cooperation with the councillors and non-governmental organizations is accompanied by his tendencies towards domination characteristic of a resolute and sometimes uncompromising governor.

\section{Attempt to explain the governance quality profile}

The authors distinguished three factors which may determine the position of the commune of Paczków on the governance quality scale. The first factor is the role of the mayor as an entity initiating and conducting various activities in the commune. The second factor is the commune's rich cultural life and its presumed consequences. The third factor is the low level of party-dependence and fragmentation of the local political life.

The role of the mayor is particularly important because it allows observations of direct relations between his governance and the implementation of the solutions for which points are scored in the governance quality index. The mayor supports various forms of local participation. During his term of office in 2015 the senior citizens council was established. It consists of 10 persons: 2 persons appointed by the mayor and 8 persons appointed by non-governmental organizations $^{99}$. Already in his policy statement, among the priorities of his governance, the mayor emphasized the necessity of supporting senior citizens, announcing the construction of a daily care centre ('Expose' 2014). During one of the town

99 https://paczkow.bip.net.pl/?a=5236 (Accessed 12 August 2018). 
Tab. 18: The structure of the Paczków town council during the four terms of office in terms of the number of seats held by particular groupings, the number of groupings, and the number of councillors affiliated with political parties

\begin{tabular}{|c|c|c|c|c|}
\hline $\begin{array}{l}\text { Name of election } \\
\text { committee }\end{array}$ & 2002-2006 & 2006-2010 & 2010-2014 & 2014-2018 \\
\hline $\begin{array}{l}\text { Supporters of Artur } \\
\text { Rolka }\end{array}$ & & & & 5 \\
\hline $\begin{array}{l}\text { "Local Government } \\
\text { Forum" Association }\end{array}$ & 2 & 5 & 5 & 2 \\
\hline Polish Peasants' Party & 2 & 3 & 3 & 2 \\
\hline Horizon & & & & 2 \\
\hline $\begin{array}{l}\text { Supporters of } \\
\text { Mieczysław Wilczek }\end{array}$ & & & & 1 \\
\hline “Opportunity” & & & & 1 \\
\hline Tradition and Future & & & & 1 \\
\hline $\begin{array}{l}\text { The Nyski District } \\
\text { League }\end{array}$ & & & & 1 \\
\hline Paczków 24 PL & & & 1 & \\
\hline Civic Platform & & 3 & 3 & \\
\hline Michael & & & 2 & \\
\hline $\begin{array}{l}\text { "Perspective" } \\
\text { Supporters of } \\
\text { Krzysztof Kumor }\end{array}$ & & & 1 & \\
\hline $\begin{array}{l}\text { The Common } \\
\text { Commune }\end{array}$ & & 2 & & \\
\hline Open to Everybody & & 2 & & \\
\hline $\begin{array}{l}\text { Everything for the } \\
\text { Town }\end{array}$ & & 1 & & \\
\hline $\begin{array}{l}\text { Supporters of Ryszard } \\
\text { Milczanowski }\end{array}$ & & 1 & & \\
\hline $\begin{array}{l}\text { Coalition of the } \\
\text { Democratic Left } \\
\text { Alliance and the } \\
\text { Labour Union }\end{array}$ & 2 & & & \\
\hline $\begin{array}{l}\text { The Paczków } \\
\text { Commune League }\end{array}$ & 3 & & & \\
\hline $\begin{array}{l}\text { "The Active } \\
\text { Commune" }\end{array}$ & 2 & & & \\
\hline Our Commune 2002 & 2 & & & \\
\hline $\begin{array}{l}\text { Everything for the } \\
\text { Town }\end{array}$ & 1 & & & \\
\hline
\end{tabular}


Tab. 18: Continued

\begin{tabular}{|c|c|c|c|c|}
\hline $\begin{array}{l}\text { Name of election } \\
\text { committee }\end{array}$ & $2002-2006$ & $2006-2010$ & 2010-2014 & 2014-2018 \\
\hline $\begin{array}{l}\text { "The Commune } \\
\text { Activist" }\end{array}$ & 1 & & & \\
\hline $\begin{array}{l}\text { Number of groupings } \\
\text { holding seats in the } \\
\text { town council }\end{array}$ & 8 & 7 & 6 & 8 \\
\hline $\begin{array}{l}\text { Number of } \\
\text { councillors } \\
\text { representing political } \\
\text { parties }\end{array}$ & 4 & 6 & 6 & 2 \\
\hline
\end{tabular}

Source: the authors' own work on the basis of the data of the State Electoral Commission.

council sessions held in 2016 the chairperson of the senior citizens council presented the results of a survey conducted among 1000 senior citizens and consequent recommendations for the commune's particular policies. The mayor accepted the recommendations and expressed his readiness for further cooperation. It should be stressed that the preparation of the statute of the senior citizens council, and establishment of the council itself, and the organization of the survey were elements of the project called "Active Senior Citizens" carried out by the Plan B Foundation and financed by the Ministry of Labour and Social Policy. In cooperation with the mayor and the director of the local cultural centre, the foundation established a senior citizens club and in all villages trained 21 leaders who subsequently, under a civic initiative procedure, submitted a request for the establishment of the senior citizens council ${ }^{100}$. Thus, the establishment of the council was the effect of cooperation among a few institutions, and the mayor's support for it seems to be an important, if not decisive, factor. An interview with one of the local senior citizens and activists shows that the mayor played the major role in the mobilization of the local community. According to the interviewee, he is interested in cooperation with representatives of non-governmental organizations, which is proved by their participation in commune council meetings during which they can put forward their proposals. People have a sense of influence on the existing reality (Interview 10) ${ }^{101}$. During the new mayor's term of

100 https://paczkow.bip.net.pl/?a=5962 (Accessed 10 August 2018).

101 It should be emphasized, however, that although the senior citizens council is perceived positively by its members, various problems appear. Sharing her opinions on 
office in 2016 the council also re-established the young citizens self-government forum whose members are pupils from schools located in the commune ${ }^{102}$. The functioning of the forum is supervised by appointed teachers and the head of the education department of the town office ('Młodzież' 2017). In 2015 the commune authorities launched a citizens budget. It should be noted however, that this project had been approved during the council's previous term of office on the initiative of the Horizon club ('Paczków też' 2014). The first edition of a citizens budget enjoyed considerable support and mobilized many local groups interested in distributing 100,000 zlotys. Nevertheless, the data in Table no. 20 show that this capital was largely exhausted. Also in 2016 the mayor reactivated the commune's quarterly entitled the "Głos Paczkowa", which had been published as a monthly magazine by the Paczków Friends' Association before 2003. The periodical is distributed free of charge in 3500 copies by the town office (ads1 2016). Because of the character of the publisher, the "Głos Paczkowa" does not present information critical of the authorities, but it can be regarded as a factor increasing the transparency of local politics, providing information on the authorities' initiatives, and promoting such initiatives. During his term of office the mayor introduced a few solutions promoting inhabitants' greater participation. They received support from the town council and are regarded as important elements of local governance.

According to a representative of the commune authorities, the local nongovernmental sector is becoming more and more active and the mayor is interested in supporting it financially, mainly in the form of grants. It can be observed that local non-governmental organizations attract more and more members (e.g.

the Third Session of the Senior Citizens' Parliament held in 2017, one of the activists writes that, "in Paczków, a senior citizens' council has been established and, in principle, there are no obstacles to its activities". At the same time she notes that "there are very important matters that senior citizens would like to have some influence on, but somehow nothing can be done about it". She adds that one of the problems in the functioning of the senior citizens' council is conflicts among the leaders of particular groups organizing various events. She writes that, "sometimes our senior citizens activists lack something to be fully mature and responsible" (Popiel 2017).

102 In this context, an important mobilization function was fulfilled by Europa Iuvenis, a non-governmental organization from Opole, which recommended that the commune establish youth councils. The mayor notified the councillors thereof during one session, adding that the topic "has been appearing since the beginning of this term of office" and "young people are willing to act in such a council". See: https://paczkow. bip.net.pl/?a=6319 (Accessed 30 July 2018). 
Tab. 19: Financial support provided to non-governmental organizations and the number of organizations that received such support on the basis of the reports on the execution of annual programs of cooperation with non-governmental organizations in the Paczków commune

\begin{tabular}{lllllllll}
\hline Year & $\mathbf{2 0 1 1}$ & $\mathbf{2 0 1 2}$ & $\mathbf{2 0 1 3}$ & $\mathbf{2 0 1 4}$ & $\mathbf{2 0 1 5}$ & $\mathbf{2 0 1 6}$ & $\mathbf{2 0 1 7}$ & $\mathbf{2 0 1 8}^{\mathbf{1 0 3}}$ \\
\hline $\begin{array}{l}\text { Financial } \\
\text { support } \\
\text { amount }\end{array}$ & $\begin{array}{l}51,000 \\
\text { zlotys }\end{array}$ & $\begin{array}{l}60,000 \\
\text { zlotys }\end{array}$ & $\begin{array}{l}35,000 \\
\text { zlotys }\end{array}$ & $\begin{array}{l}63,000 \\
\text { zlotys }\end{array}$ & $\begin{array}{l}81,000 \\
\text { zlotys }\end{array}$ & $\begin{array}{l}92,000 \\
\text { zlotys }\end{array}$ & $\begin{array}{l}121,000 \\
\text { zlotys }\end{array}$ & $\begin{array}{l}94,500 \\
\text { zlotys }\end{array}$ \\
$\begin{array}{l}\text { Number of } \\
\text { organizations } \\
\text { receiving } \\
\text { support }\end{array}$ & & 5 & 6 & 8 & 16 & 16 & 15 & $-? ?$ \\
\hline
\end{tabular}

Source: the authors' own work on the basis of the reports on the execution of annual programmes of cooperation between the Paczków commune and non-governmental organizations for the years 2011-2018.

the pigeon fanciers' association or the anglers' association), also from the neighboring communes, because "a lot is going on in them" (Interview 7). Interviews with a representative of non-governmental organizations also indicate that the mayor supports them financially: "Every year, whatever we plan to do, we eventually organize" (Interview 9). An example of such support for non-governmental organizations is making local sports facilities (a sports hall and a stadium) open to associations for free ('Dwa' 2015). This form of social mobilization is also visible in the reports on the execution of annual programs of cooperation with nongovernmental organizations for the years 2011-2018. Table no. 19 shows that during the new mayor's term of office the number of non-governmental organizations receiving subsidies from the town office was doubled and the amount of provided financial assistance increased considerably (the average for the years 2011-2014 was 52,000 zlotys, while for the years 2015-2018 - 97,000 zlotys).

Non-governmental organizations are also invited in the capacity of partners to participate in some EU-funded projects aimed at town revitalization ('Zrewitalizują' 2017). They also often appear in the local press.

Nevertheless, this picture of support for local non-governmental organizations should be supplemented with critical opinions according to which there are no

103 A report for the year 2018 is not available yet. The given amount reflects the level of support specified in the 2018 programme of cooperation between the Paczków commune and non-governmental organizations (Uchwała nr XLIII/342/2017). 
true partnership and honest dialogue between the mayor and NGOs. Cooperation with those organizations can be assessed in different ways and some leaders are not willing to cooperate with the mayor because of his authoritarian tendencies and uncompromising character, which put many activists off. For example, consultations about a large EU project connected with the renovation of the market square surface were attended by many inhabitants, but their character was that of unidirectional announcements made by the authorities. Participants' suggestions, for example those concerning the preservation of old cobblestones, were not taken into consideration. The lack of partnership was experienced particularly strongly by the lovers of the history of Paczków. They constitute a small group, but express great dissatisfaction with the conduct of work related to the revitalization of the Paczków market square. The asymmetry of relations between the authorities and non-governmental organizations results also from the financial weakness of the non-governmental sector, which depends on public funds (after all, this is the source of weakness of all NGOs in Poland). It should also be noted that the initial outburst of social activity stimulated by the first edition of the citizens budget ( 21 submitted proposals) was weakened after some time and now the citizens budget is much less popular among inhabitants. This is to a considerable extent the result of actions taken by the authorities. They changed the application preparation rules, introducing the obligation to submit detailed cost estimates (Interview 8). A comparison between the application forms effective respectively in 2015 and 2017 shows that the authorities not only introduced the obligation to submit a "detailed cost estimate" or "a detailed cost calculation" of a proposed project but also narrowed down the scope of proposals to initiatives related to construction, modernization, or renovations operations. Thus, the possibility of submitting proposals for so-called soft projects was eliminated. But it should be noted that the minimum number of people supporting a given project was reduced from 25 to 15 .

Interest in the citizens budget decreased also because after one of the projects proposed by young people had won, it was not eventually executed in its original form, but was "scaled down", which means that the mayor and other officials narrowed down its scope, invoking issues related to security and costs (Interview 8). Consequently, in 2018 town inhabitants did not submit a single proposal and only two projects were proposed for the rural part of the citizens budget ${ }^{104}$. It is worth mentioning that during one of the council sessions the mayor had to defend the subsequent edition of the citizens budget for the year 2017 when

104 The citizens budget in Paczków amounts to 50,000 zlotys to be spent on projects proposed by villages and 50,000 zlotys for projects proposed by the town itself. 
Tab. 20: The citizens budget of the Paczków commune - the number of submitted project proposals and the number of participating voters

\begin{tabular}{lrrrr}
\hline Edition & $\mathbf{2 0 1 5}$ & $\mathbf{2 0 1 6}$ & $\mathbf{2 0 1 7}$ & $\mathbf{2 0 1 8}$ \\
\hline Number of valid votes cast & 3152 & 4176 & 4449 & 1879 \\
Number of proposals put to vote & 14 & 6 & 5 & 2 \\
Number of rejected proposals & 6 & 0 & 0 & 0 \\
\hline
\end{tabular}

Source: the authors' own work based on the data from the Paczków town office.

two councillors opposed its organization. They indicated that some projects were "ill-considered", "underestimated". Referring to the necessity of modernizing the market square, they claimed that "instead of getting sidetracked, the council should do something concrete". The mayor answered that he respects all opinions, but "eliminating the citizens budget, the council would move in the wrong direction" because "the citizens budget is a grass-roots social initiative" 105 . Thus, we are in a situation in which some councillors show their lack of understanding for the idea of a citizens budget as a participatory tool, reducing it to a mechanism aimed at bringing about concrete and measurable infrastructural results. On the other hand, the mayor appears to be an advocate of this idea, emphasizing its mobilizing and civic functions, which he announced in his policy statement, declaring that "no decision concerning the commune without its inhabitants' consent" ('Expose' 2014).

Besides supporting participatory solutions, the mayor is involved in the execution of an extensive investment programme for the commune based to a considerable extent on external financing. He advocates "development through investment" (Interview 7). It is worth mentioning that he defines the commune as an area which has to be pulled out of backwardness caused by his predecessors ${ }^{106}$. He started his governance from unpopular decisions and saving

105 https://paczkow.bip.net.pl/?a=6319 (Accessed 10 September 2018).

106 For example, during a town council session the mayor said that Paczków was a backward commune and compared it to the better functioning commune of Otmuchów. According to him, the past 20 years were wasted, especially as regards funds available under EU programs (see: https://paczkow.bip.net.pl/?a=6318; accessed 10 September 2018). In one of the interviews given at the end of his first term of office, he said that during 16 years the commune authorities had not managed to create a special economic zone for businesspersons: "This is the effect of many years of neglect on the part of my predecessors. It has to be said straight: the lack of workplaces and infrastructure, plots of land open to development didn't encourage young people to stay here. People 
projects. The personnel of the town office was reduced from 64 to 53 employees and the number of lighting points on town streets and in commune institutions was decreased seriously ('Musieliśmy' 2016). In his policy statement, the mayor referred to the idea of an "efficient office" on four occasions and mentioned EU operational programs, drawing attention to the necessity of establishing a special economic zone for potential businesspeople ('Expose' 2014). In the years 20152018 the town office acquired 22.6 million zlotys of external financing for 72 projects with the combined value of almost 40 million zlotys. In the year 2015 the value of the commune's budget expenditures was 35 million zlotys. The budget for the year 2018 was planned at the amount of 67 million zlotys, including 23 million zlotys of capital expenditures (Wolniak 2018). The town office took actions aimed at establishing a special investment zone. It approved a new study on the commune's conditions and directions of spatial development ${ }^{107}$. The commune carried out a few serious infrastructural projects. The most representative of them was the project of renovating the surface of the market square in Paczków. The aim of the project is to restore the historic character of the centre of the town. It is being carried out in partnership with the Czech town of Jawornik as part of the plan to establish a cross-border tourist services centre ('Rewolucja' 2016). The project is not only large (it is worth 9.5 million zlotys) but also visible and bothersome for all inhabitants of the commune as the centre of the town has changed into a construction site, which hinders vehicle traffic and activities of the businesses located in the market square. But it also shows the authorities' readiness and determination to carry out difficult tasks and symbolizes changes following the election of the new mayor.

Nevertheless, the mayor does not function in a social and political vacuum. Therefore, it is necessary to focus on the commune's another distinctive feature - its rich cultural life. In our opinion, it does influence Paczków's governance profile. Located in the market square, the Visual Artists' House has been an important cultural institution and arts centre since the 1970s. The importance of this place for the local community was confirmed by its reactions to the district board's attempts made in 2013 to liquidate the arts centre and sell the building, which mobilized many inhabitants in its defence. The mayor and

don't want to live in a backward commune, without opportunities for development and prospects for the future. Whole families were leaving this place. We'll do our best to reverse this trend" (Wolniak 2018). This information is important because it yet again raises the question about the value of the indexes used in the research, but we will return to this matter at the end of this study.

107 paczkow.bip.net.pl/?a=7024 (Accessed 10 September 2018). 
the town council adopted a resolution opposing the district board's decision and inhabitants established a Public Protest Committee which collected 1593 signatures of inhabitants demanding its withdrawal. The matter attracted the attention of the regional press, radio and television. Under the pressure of the inhabitants of Paczków, the district board withdrew its decision and ceded the title to the Visual Artists' House to the commune of Paczków (Ziółkowski 2014). The effectiveness of that defence shows also that the commune is capable of bottom-up integration around inhabitants' common interests anchored in local cultural institutions.

In the years 1985-2003 the Paczków Friends' Association published the "Głos Paczkowa", a local newspaper which presented also information important from the point of view of local government politics. Since 1989 the town has organized "Terepaczków", an all-Poland young people’s music festival dedicated to travel songs popular among scouts spending summer holidays in the Bieszczady Mountains ${ }^{108}$. Another dynamic institution is the Centre of Culture and Recreation, which cyclically organizes the Paczków Film Meetings in the Kopernik cinema. The fourteenth edition of this event was organized in 2017. The same year also witnessed the fifth edition of the "Vocal Camp" singing workshop. The centre was also the organizer of the aforementioned thirteenth competition for the best poem about Paczków.

Since 1978 Paczków has cooperated with the French town of Uzès and since then Polish and French delegations have been exchanging visits. The first such visit took place in 1978 when 44 inhabitants of Uzès visited Paczków. Such visits were co-organized by the Paczków Friends' Association, but its dissolution in 2007 froze cooperation. In 2015, on the initiative of the new mayor, the French visited Paczków again ('Delegacja' 2015). In 2016 a Polish-French Association was established in Paczków. Another important element is cooperation between the town authorities and the German town of Einbeck. In 1992 the authorities of the two towns entered into a cooperation agreement. Einbeck is a German town in which the inhabitants of pre-war Paczków had settled after the war. Thanks to the agreement, the towns organize youth exchange programs, and bee-keepers and voluntary fire service units share their experiences. The delegations of the local authorities visit their partner towns. For example, in 2003 the delegation from Einbeck visited Paczków under the motto of "Small steps towards Europe". In the years 1992-2003 this cooperation at the level of local governments was

108 More information about this event can be found on its website: http://terepaczkow. $\mathrm{pl} /$. 
part of the more general tendencies towards cultural integration with Europe and Poland's preparations to join the EU (Paczków-Einbeck 2002: 4).

What is worth noting is the intensifying activity of local non-governmental organizations, primarily those functioning in the areas of culture, science, history and sport. Since 2013 Paczków has been the seat of the "Idea of a Notion" Biernacki Family Foundation, which has established the Metamuseum of the Automotive Industry. The foundation also runs a modern art gallery which organizes various cultural events (e.g. an international plein-air workshop), and its founder has opened a vineyard, which is a regional attraction. Since 2014 the aforementioned "Pegasus" Association has organized cyclical events (e.g. a bicycle race) aimed at promoting tourism and the history of Paczków ${ }^{109}$. The year 2016 witnessed the establishment of "The Three for Children", an association of teachers and parents connected with one of the primary schools. It is known for the organization of the so-called Paczków Ten or the Race of Mountains and Lakes.

In 2013 a so-called Paczków Tourism Card was established. It was a grassroots initiative of local entrepreneurs, active also in non-governmental organizations, aimed at creating a discount card offering its holders discounts at about 40 establishments such as restaurants, shops, sports and cultural centers, as well as local tourist attractions. The card is to promote the commune and particular businesses participating in the project ('Paczkowska' 2013). The functioning of this "tourism product" shows that Paczków is a place of complex relations among the local non-governmental organizations, businesspeople and cultural institutions. These relations are based on a motive of cooperation aimed at developing local tourism as well as informal connections existing thanks to the sociological uniqueness of a small town. One of the local activists representing non-governmental organizations and familiar with the specific character of this initiative stresses the important role of informal connections facilitating cooperation among businesspeople, non-governmental organizations and the commune's public institutions (Interview 9). Thus, it is possible to indicate the shaping of unique social capital consisting in the integration of local groups representing various sectors, which support one another in promoting their respective interests. The commune's still unused tourist qualities become a force encouraging them to cooperate rather than to compete.

109 The information comes from the association's website: http://pegaz.org.pl/o-nas/. 
The question can be posed about the role of a rich cultural and social life from the perspective of the commune's particular place on the governance quality scale. We are of the opinion that such a state of affairs indicates a large number of local leaders capable of expressing their opinions, manifesting their expectations, and mobilizing local communities. They promote their community's development, advance its interests (but also their own sector-specific interests), and constitute a force capable of influencing the local authorities, with which, after all, they have numerous relations resulting from the implementation of common initiatives. In such conditions, it is much more probable that local authorities will be characterized by openness, people will compete for power, local media will be established, and people will support solutions oriented towards participation. It should be noted that the commune's rich social and cultural life is accompanied by the aforementioned anchoring of many cultural initiatives in the building of people's identification with Paczków as their local homeland and the presentation of its unique features. One of our respondents indicates that the inhabitants of Paczków "love their town" and many households still keep local postcards printed before the war or during the town's glorious period in the People's Republic of Poland. The strength of this identification is also reflected in the establishment of the Paczków Friends' Association (Interview 8). Thus, the rich social and cultural life coexists with the clearly crystallized identity.

Finally, it is also of some importance that local politics is characterized by a low level of party-dependence and a high level of fragmentation in the town council. It has already been mentioned that the former is characteristic of small communes with 10,000-20,000 inhabitants. With only two councillors elected from party lists and the mayor representing so-called single non-partyism, the commune meets a certain general standard. Nevertheless, it does not change the fact that a low level of party-dependency is perceived as a positive phenomenon from the point of view of the quality of governance because it reduces ideological polarization and facilitates decision makers' focus on concrete problems of the commune. In such conditions, it is easier to pursue compromise and cooperation within the council and in relations between the council and the mayor. As it has been mentioned earlier, the analysis of the minutes of commune council sessions for the year 2016 shows that the commune is dominated by a spirit of cooperation and high support for the mayor. It seems that another influential factor is a high level of political fragmentation (8 groupings in the town council) which hinders the creation of strong opposition blocks, but also makes it easier for the mayor to acquire support for his own initiatives from individual councillors. In the long run it is possible that the absence of critical opposition groups may have a negative impact on the quality of local politics. Nevertheless, the effective 
implementation of large investment projects and solutions oriented towards participation is easier in the conditions of consensus and a strong mandate of the executive body.

In summary, the commune of Paczków is characterized by the strong leadership of the mayor, who supports pro-participation solutions and has a clear vision of the commune's development. At the same time, his actions are performed and possible thanks to strong social, cultural, and political foundations. The commune's rich social and cultural life, bottom-up cooperation among the representatives of various groups, and inhabitants' identification with their local homeland constitute social capital making it easier for the executive body to govern. Simultaneously, such activities enjoy the support of fragmented and rather non-partisan political groups deeply rooted in the local reality and its interests. Thus, what we witness is mutual interactions and cooperation among the most important actors of the local political stage whose driving force is the executive body.

\section{Domaszowice}

\section{Governance quality profile}

The conducted quantitative analysis indicates that the commune of Domaszowice holds the lowest position on the governance quality scale. In three out of the five indexes, it scored not more than 1 point; it scored 2 points for efficiency. It is simultaneously a commune with a low ethnic fractionalization index.

The commune scored less than 1 point in the sub-index of participation. The number of people using the services of the commune public library is relatively low; in 2015 it was 48 per 1000 inhabitants. Slightly less than $8 \%$ of voters supported voters' election committees. It means that citizens' election initiatives enjoy limited support of the local community. The average mark in junior secondary school social science and history examination is $45.6 \%$. The commune has about a dozen non-governmental organizations and no public benefit organizations. It should be noted, however, that associations in small communes may be characterized by a low level of formalization; if there are any non-governmental organizations in them, they are often local branches of big national organizations such as the OSP, PTTK or the Association of Pensioners (Trutkowski and Mandes 2005: 182-185). In the case under analysis, the majority of associations are voluntary fire service units and sports clubs related to particular villages. An interview with a representative of the commune authorities indicates that such organizations as voluntary fire service units or village housewives' associations still enjoy considerable respect in the commune and the most dynamic 
grass-roots initiatives are the effect of cooperation among village leaders, housewives' associations, and voluntary fire service units. The respondent referred also to three other associations, but two of them do not exist anymore. These shortlived associations were initiated in the spring-summer season, which is a period of increased activity in the local public life, still influenced by the rhythm of the seasons of the year (Interview 11).

In the dimension of openness, the commune scored 1 point, which indicates the existence of the following features. Among the fifteen councillors there is only one woman; out of the five managerial positions distinguished in the research, two positions are held by women (commune secretary and social assistance centre manager). The commune does not have a youth council or a senior citizens council and the poverty risk index as assessed by the Regional Social Policy Centre was relatively high and equaled 0.52 .

The commune has the highest efficiency index, which results from a high level of capital expenditures per inhabitant in 2015 (600.71 zlotys) and relatively high income per inhabitant in 2015 ( 1626.72 zlotys). As far as the other sub-indexes of efficiency are concerned, among all beneficiaries of social assistance, $64 \%$ were permanently dependent on it ${ }^{110}$. The commune also had relatively high current expenditures on public administration per inhabitant in 2014 (509.83 zlotys), although it should be noted that this is a nationwide phenomenon, i.e. administration maintenance costs per inhabitant are higher in small rural communes (Swianiewicz 2014: 14-15). The commune does not use any quality management system distinguished by the authors.

As far as accountability is concerned, the commune does not have any local press independent of the authorities ${ }^{111}$. It scored one point for publishing internal

110 In this respect, a picture of the commune is a reflection of a picture of the province because in the whole province, $64 \%$ of the beneficiaries of social assistance depend on it on a permanent basis. This index has the lowest value in the commune of Turawa (26\%), and the highest (100\%) in the communes of Kamiennik and Świerczów (ROPS 2016b: 39).

111 Maybe this is why there are so many comments to some articles about the commune of Domaszowice published in the regional daily "Nowa Trybuna Opolska". The article describing the public prosecutor's charges against the commune leader and the commune secretary concerning illegal influence on the course of the 2014 local government elections received 191 comments. Their analysis shows that they were written by people familiar with matters related to the commune (e.g. some people commented the harvest festival in which they themselves participated) and clearly divided in their opinions about the commune leader. His opponents write that the 
inspection reports for the years 2015-2016, but it should be remembered that the publication of just one document sufficed to fulfil this criterion. The accusation of the commune's failure to publish the Regional Accounting Chamber's postinspection reports on its Public Information Bulletin was also mentioned in an interview with the leader of the opposition in the commune council. According to him, it is a deliberate action aimed at hiding irregularities identified by the Chamber from the public (Interview 12). There were four candidates running for the post of mayor in the 2014 local government elections. Before 2 June 2017 the commune's Public Information Bulletin had not contained any property statements. Among the 15 councillors, two have higher education.

With respect to openness, the commune scored 1 point because of the publication of the minutes of commune council sessions for the year 2017. It did not answer our questionnaire by the proposed deadline (eventually, we did not receive any response from it, even after asking the same questions under the procedure provided for in the Public Information Access Act) and did not provide us with an annual programme of cooperation with non-governmental organizations for the year 2017. None of the non-governmental organizations submitted any comments to such a programme during relevant consultations. The commune did not adopt any resolution specifying the procedure for, and principles of, conducting public consultations. An analysis of the minutes of commune council sessions held in 2016 showed that the matter of relations with non-governmental organizations did not arouse the councillors' interest. None of them took the floor during votes on the approval of the report on the execution of the annual programme of cooperation with non-governmental organizations and the approval of a new annual programme of cooperation with non-governmental organizations ${ }^{112}$.

commune office functions as if it were a private property of a few persons ("Korea in the Domaszowice edition"); there appear accusations of unethical enrichment in the case of some officials, using commune office employees for the commune leader's private purposes ("lawn mowing"), or the lack of independent media that would present the true picture of the commune and counteract the authorities' "propaganda of success". Such critical opinions are, obviously, anonymous. Therefore, they should not be regarded as a reliable source of data concerning particular persons, but their number and content show that there are many people critical of the situation in the commune and feeling the need to share their opinions in a forum run by an independent medium (Staśkiewicz 2017).

112 See: http://www.bip.domaszowice.pl/download/attachment/5799/protokol-z-xvsesji-rady-gminy-domaszowice-w-dniu-15-kwietnia-2016-r.pdf and http://www. bip.domaszowice.pl/download/attachment/6100/protokol-z-xx-sesji-rady-gminydomaszowice-w-dniu-16-listopada-2016-r.pdf (Accessed 3 June 2018) 


\section{Geographic and demographic position}

The commune of Domaszowice was established in 1973 as part of the historical Namystów region. It is located in the northern part of the Opolskie province, where it borders on the Wielkopolskie province. Domaszowice is a rural commune; it consists of 11 hamlets and 13 villages (Morga, Bak 2012: 2). The commune is crossed by the Kluczbork-Oleśnica national road. It has a direct railway connection with Wrocław (1.5 hours), but does not have one with Opole (a change is necessary in Kluczbork). In 2015 the commune was inhabited by 3647 people, which made it one of the least populous communes in the Opolskie Province. In 2014 the average population of a Polish commune was 15,500 people (Kaczmarek 2016: 72). Thus Domaszowice should be classified as a small commune. According to the data for 2013, Poland had 618 small communes with fewer than 5000 inhabitants and the average rural commune comprised from 11 to 20 villages (Swaniewicz 2014:6-10). Domaszowice is an example of a small commune and does not constitute any exception in terms of its population. With respect to population density, in 2015 the commune was in the last but one place in the province with 32 inhabitants per $1 \mathrm{~km}^{2113}$.

\section{Economy}

Its character is typically agricultural; arable land constitutes $60 \%$ of its area, and forests - $30 \%$ (Morga, Bak 2012: 2-4). In 2015 the share of the registered unemployed in the total number of working-age population was $5.6 \%$, while the average for the Namysłowski district was $6 \%^{114}$. According to the Local Development Plan for the Years 2007-2013 (the commune does not have an updated development strategy), the four major employers in the commune are the following entities:

a) the state enterprise Ferma-Pol in Zalesie (pig husbandry),

b) the Group of Schools in Domaszowice,

c) the Domaszowice commune office,

d) Fuels Trade Enterprise - Piotr Owczarek in Domaszowice ${ }^{115}$.

113 https://opole.stat.gov.pl/vademecum/vademecum_opolskie/portrety_gmin/ namyslowski/gmina_Domaszowice.pdf (Accessed 22 May 2018).

114 https://opole.stat.gov.pl/vademecum/vademecum_opolskie/portrety_gmin/ namyslowski/gmina_Domaszowice.pdf (Accessed 22 May 2018).

115 The last firm selling fuels is no longer located in Domaszowice; its registered office has been moved to Oława. 
It also means that the commune and the entities subordinate to it are some of the major employers. In the territory of the commune, in the village of Zalesie, the Opolskie province's first biogas plant is located. It acquires methane from pig slurry generated in Ferma-Pol. The facility cost 30 million zlotys (PAP 2012) and appears to be the only large private capital expenditure project carried out in the commune in the past five years.

\section{Specific features in the material, symbolic, and identity-related areas}

Among the commune's characteristic features, it is possible to distinguish its natural and tourist advantages. In its territory there are 65 stationary and 9 movable monuments of history and nature (all 6 monuments of nature are located in the village of Gręboszów), archaeological sites, a manor park and a protected landscape area called the Forests of Stobrawa and Turawa (Morga, Bak 2012: 2-4). Despite having interesting natural features, the commune is not an attractive tourist destination and has no tourist infrastructure. It has no tourism development strategy or tourism product. There is also no possibility of overnight accommodation ${ }^{116}$. In the commune there are 64 archaeological sites and numerous monuments of architectural history (distilleries, manor farms, tombstones). Among the commune's buildings, it is possible to distinguish the 40th Anniversary housing estate (a number of small blocks of flats erected in the past for FermaPol employees) and the small former hotel located in the centre of Domaszowice. Nevertheless, it is possible to venture an opinion that the commune's characteristic features constituting the elements of the local elites' identity include the long-lasting governance of the Democratic Left Alliance, which can be perceived as a local phenomenon in the context of the party's gradual weakening after 2005.

\section{Political life}

As it has been mentioned above, one of the major features is the long-lasting domination of one party governing the commune, namely the Democratic Left Alliance. The statements made by the former commune leader (in the years 19901994) and the councillor in the years 2014-2018 indicate that during the period of the People's Republic of Poland the structures of the Polish United Workers' Party enjoyed considerable support in the commune. According to one of the

116 Using an Internet search engine, the author failed to find any overnight accommodation in the commune of Domaszowice. He managed to find accommodation in an agrotourism farm located in a neighboring commune. 
Tab. 21: The structure of the council of the commune of Domaszowice during the past four terms of office in terms of the number of seats held by the particular groupings

\begin{tabular}{|c|c|c|c|c|}
\hline Name of election committee & $2002-2006$ & 2006-2010 & 2010-2014 & 2014-2018 \\
\hline $\begin{array}{l}\text { SLD (in } 2002 \text { SLD-Unia Pracy; } \\
\text { in } 2014 \text { SLD Lewica Razem) }\end{array}$ & 8 & 8 & 11 & 8 \\
\hline PIS & & & 1 & 7 \\
\hline PSL & 6 & 3 & 1 & \\
\hline $\begin{array}{l}\text { The Namysłów Region } \\
\text { Development Forum }\end{array}$ & & 3 & 3 & \\
\hline $\begin{array}{l}\text { The National Party of Old Age } \\
\text { and Disability Pensioners }\end{array}$ & & 1 & & \\
\hline Gręboszów & 1 & & & \\
\hline
\end{tabular}

Source: the authors' own work based on the data from the National Electoral Commission.

jokes popular at that time, $104 \%$ of the inhabitants of Domaszowice were party members (Staśkiewicz 2015). The data included in the table 21 show that after 2002 the majority of seats in the commune council were held by SLD councillors, and in the years 2010-2014 it was the decisive majority of 11 out of 15 councillors.

Simultaneously, the council was undergoing the process of political polarization because in the years 2002-2014 non-SLD councillors represented first two, and subsequently three different organizations, while in the years 2014-2018 the council was dominated by just two political groupings: SLD and PiS ${ }^{117}$. The incumbent leader has governed the commune since the times of the People's Republic of Poland, when he held the post of so-called prefect, with a break in the period 1990-1994, when the posts of commune leader was held by one of the present leaders of the opposition in the commune council (Staśkiewicz 2015). Thus, we deal with the case of one commune leader's remaining in power for many terms of office, which is characteristic of rural communes where holding power for four terms of office occurs the most often.

It should be noted that holding an office for many terms coexists with the commune council's being dominated by the same political grouping as the one represented by the commune leader. Thus, the commune leader enjoys arithmetic advantage in the council with respect to votes on resolutions concerning matters of key importance for the commune, such as a budget resolution, votes of approval, or

117 Although the councillors who had run as PiS candidates act officially as the Independent Councillors Club. 
a long term financial plan. An analysis of the minutes of the commune council sessions held in 2016 with respect to councillors' activity showed that the councillors representing the majority rarely submitted requests or asked questions. Their activity in this area was limited to obtaining information on matters related to such problems as road repairs or the cutting of trees and bushes on particular plots of land. The eight SLD councillors took the floor on 17 occasions; the most active of them spoke 5 times, while the least active one did not take the floor even once ${ }^{118}$. Meanwhile, the seven opposition councillors took the floor altogether 134 times. It was mainly the leaders of the opposition in the council that were responsible for this result; they took the floor 49,34 , and 31 times respectively.

The analysis of the council meeting minutes projects an image of a group of 8 passive councillors supporting the commune leader in all votes and a group of 3 opposition councillors critical of the commune leader and accusing him of treating the commune as private property. There are many squabbles, accusations of absolutism, and demands that the commune leader resigns. During the 18th session, when one of the important items on the agenda was the restructuring of the commune's debt under so-called subrogation, the opposition councillors invited journalists to monitor the course of the meeting, which the commune leader referred to as a "spectacle" organized by the opposition councillors. During that session the opposition councillors accused the commune leader of bad management of the commune reflected in the debt of 5 million zlotys and demanded his resignation. It should be noted at this point that one of the councillors supporting the leader proposed that the opposition present an alternative solution to the commune's financial problems. The incumbent leader's main opponent and former leader answered that the commune's financial management was the responsibility of the leader and that the credits had been obtained during the previous council's term of office, that is before $2014^{119}$. Thus, the former leader did not put forward any constructive solutions, but implied that he was not responsible for the incurred debt.

During the vote on the resolution concerning subrogation the seven opposition councillors voted against the proposal submitted by the leader. Similarly,

118 This drew the attention of the deputy chairperson of the commune council, who accused the 8 councillors of being unprepared for council sessions, failing to ask questions, and getting excited about "tree branch cutting". http://www.bip.domaszowice.pl/download/attachment/6006/protokol-z-xviii-sesji-rady-gminy-domaszowice-w-dniu-19wrzesnia-2016-r.pdf (Accessed 23 May 2018).

119 http://www.bip.domaszowice.pl/download/attachment/6006/protokol-z-xviii-sesjirady-gminy-domaszowice-w-dniu-19-wrzesnia-2016-r.pdf (Accessed 23 May 2018). 
during the 16th session seven opposition councillors voted against the resolution approving the leader's discharge of duties ${ }^{120}$. These votes show a high intensity of conflict over the matters of key importance for the proper functioning of the commune. Also the deputy commune leader drew attention to a lack of constructive criticism on the part of the opposition. In the newsletter published by the commune office, he calculated that during the whole term of office, i.e. 32 sessions, the opposition councillors submitted only one of the total number of 204 resolutions $^{121}$. At this point, it should be added that the commune's statute provides for the possibility of initiating a resolution by a group of 5 councillors ${ }^{122}$.

Attention should be drawn to the fact that the opposition councillors monitor and supervise the functioning of the commune authorities, which manifests itself in critical comments on the functioning of the commune. During the analyzed sessions the councillors asked questions concerning, for example, the course of a competition procedure for the appointment of director and deputy director of the commune's junior secondary school, agreements entered into with a consulting firm providing services related to the subrogation process and the costs of such services, or the problem of the poor effectiveness of acquiring EU funds ${ }^{123}$. They also highlighted various cases of wastefulness. The opposition councillors also work for the sake of transparency. A case in point is a complaint

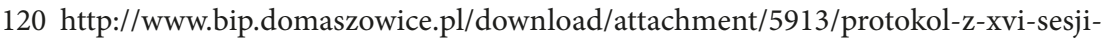
rady-gminy-domaszowice-w-dniu-21-czerwca-2016-r.pdf (Accessed 23 May 2018).

$121 \mathrm{http}: / /$ domaszowice.pl/download/attachment/6630/gazeta-gminy-domaszowice-nr16-2018-wyd-styczen-luty.pdf (Accessed 2 June 2018).

$122 \mathrm{http}: / /$ www.bip.domaszowice.pl/download/attachment/5799/protokol-z-xv-sesjirady-gminy-domaszowice-w-dniu-15-kwietnia-2016-r.pdf (accessed 22 May 2018).

123 Enclosure 10 to minutes no. XV.2016 of the council session shows the position of the commune of Domaszowice with respect to the use of EU funds in comparison to the other communes in the district. The numbers of agreements entered into by the respective communes under the Regional Operational Programme of the Opolskie Province for the years 2007-2013 were as follows: Domaszowice - 1; Świerczów - 2; Wilków - 3; Pokój - 6; Namysłów - 22. With respect to agreements entered into under the regional component of the Human Capital Operational Programme for the years 2007-2013, the respective numbers were as follows: Wilków - 8; Pokój 17; Świerczów - 18; Domaszowice - 19, Namysłów - 58. These data show that Domaszowice achieved a poor result in acquiring EU funds, which are spent to a considerable degree on infrastructure (so-called hard projects), while in the case of soft projects related to human capital, the commune was second best behind Namysłów (http://www.bip.domaszowice.pl/download/attachment/5913/protokol-z-xvi-sesjirady-gminy-domaszowice-w-dniu-21-czerwca-2016-r.pdf; accessed 23 May 2018). 
filed by one of them with the council chairperson and relating to the authorities' failure to publish the commune leader's orders, external inspection reports concerning the education system, or minutes of commune council sessions in the Public Information Bulletin. The chairperson proposed a motion to have the matter examined by the audit committee ${ }^{124}$. It is an example of an activity aimed at increasing the commune's transparency and initiated by the opposition in the commune council, which is an institution responsible for accountability. This case shows causal relationships between the existence of accountability mechanisms and transparency because during the following session the deputy commune leader explained why the aforementioned documents had not been published (the lack of required software) and declared that the missing documents would be published by the end of the first quarter of 2017 .

This critical and controlling attitude towards the executive body is accompanied by some kind of powerlessness on the part of the opposition councillors, which results from the arithmetic of support for the commune leader allowing him to force through his own ideas. It also seems that the commune leader's strong position in the council may go hand in hand with the opposition councillors' lack of understanding for the controlling function. A case in point is a statement of the council chairperson. Commenting on interviews conducted by journalists with some councillors, he said that "it's unbecoming" to assess other councillors ${ }^{125}$. The newsletter published by the commune authorities constitutes a measure of their reaction to critical opinions about the functioning of the commune office. An interview with the leader of the opposition in the commune council indicates that the opposition councillors requested that at least one page in the newsletter be given at their disposal, but their request was declined. Justifying the negative decision, the commune office stated that the opposition would use such space in the newsletter to criticize the authorities. Therefore, the opposition is working on publishing its own newsletter entitled the "Echo Domaszowic" which is to be a counterbalance for the "commune authorities' propaganda mouthpiece" ${ }^{\text {" }}$. The

$124 \mathrm{http}: / /$ www.bip.domaszowice.pl/download/attachment/6099/protokol-z-xxi-sesjirady-gminy-domaszowice-w-dniu-06-grudnia-2016-r.pdf (Accessed 23 May 2018).

$125 \mathrm{http} / /$ www.bip.domaszowice.pl/download/attachment/6051/protokol-z-xixsesji-rady-gminy-domaszowice-w-dniu-05-pazdziernika-2016-r.pdf (Accessed 23 May 2018).

126 The respondent provided the author with the first trial page of the first issue of the newsletter being prepared for circulation. A fragment of the editorial: "Dear Inhabitants of the Commune of Domaszowice!!! Today we give you the first issue 
councillor also emphasized that another problem was limited access to information on the office's activities - officials provide opposition councillors with information on the office's current work very unwillingly (Interview 12). An analysis of council session minutes shows that this accusation appeared also during one session because some information related to the functioning of the commune is submitted to councillors a few days before a session or on the day of a session, which prevents councillors from preparing properly for a council session.

The most significant example of controlling activity on the part of the opposition is an election complaint filed against the commune leader in connection with the conduct of the 2014 local government elections in the commune. The incumbent leader won with the candidate of the Law and Justice party in the second round, with the majority of 54 votes. According to one of the opposition leaders (and the commune leader of Domaszowice in the years 1990-1994), the victory was a result of election manipulations, therefore, he filed an election complaint accompanied by a list of 50 names of people who, in his opinion, did not live in the commune, but voted in the elections. The administrative court which examined the case dismissed the complaint, but the public prosecution office became involved in this matter and, in November 2016, charged the commune leader and the commune secretary with violating the freedom of voting by persuading people to vote for a particular candidate, driving voters to the seats of election commissions, entering ineligible people in the electoral register, or urging witnesses to make false statements (Staśkiewicz 2017). The same councillor filed also a complaint about the public prosecution office's sluggishness to the minister of justice and simultaneously the public prosecutor general, requesting that the investigation be under special supervision and the community be governed by a commissioner. The letter reads that before the elections, the commune office had received 70 requests for permanent residence registration from people who did not live in the village and were related to the commune leader, the commune secretary, the councillors supporting the leader, or the commune office's employees (Skarga 2017). On the one hand, it is a case of

of our new local government newsletter! We will do our best to convey the objective truth despite the commune office's propaganda mouthpiece, where the commune leader's subordinates sing his praises, while the commune is drowning in debt. It is only natural that newsletters published by communes are not objective and serve the authorities' interests only. We are independent, and to the best of our abilities, we are going to show the true face of those in power and their actions, and you will form your own opinions on them" (the material in possession of the authors). 
local authorities being controlled by the opposition, but, on the other hand, it should be regarded as an element of electoral competition and an attempt to use the available accountability mechanisms (courts, public prosecutors, regional media ${ }^{127}$ ) for the purpose of weakening a political opponent.

\section{Attempt to explain the governance quality profile}

To some extent, the conducted analysis touches on the issues of the quality of governance in a small rural commune and the influence of the size of a commune on governance quality. The literature on the subject indicates that in a small community, because of a short distance between authorities and inhabitants, it is easier to pursue the ideals of democracy, but there are barriers to the effective provision of public services. Based on a survey carried out in 2007, the research conducted by Paweł Swianiewicz shows that small Polish communes are characterized by greater interests in local politics, better knowledge of the functioning of local government authorities, and greater trust in such authorities. The inhabitants of small communes, particularly those with higher education, declare a greater sense of influence on the course of public affairs. With regard to the efficiency of authorities, inhabitants of small communes have better opinions of the quality of services provided by local government offices and public services (education, health, social assistance), while people living in larger communes are satisfied more with the development of infrastructure and the promotion of economic development (Swianiewicz 2010:12-16). It seems that the data gathered by the authors allow them to present a few basic themes.

First of all, attention should be drawn to the long-lasting domination of one political grouping, including its leader, as one of the important factors contributing to the commune's low government quality index. Both the representative of the opposition in the commune council and the representative of the commune authorities drew attention to one particular feature, mainly the centralized management model based on the commune leader. A professed opponent of holding an office for many terms, the leader of the opposition in the council described the commune as a "crystal clear" specimen of a "political scene embedded in concrete". He emphasized that comparing Domaszowice to other communes in the district, one could easily see civilization backwardness; additionally, the commune was "always last" in various rankings, e.g. one organized by the periodical

127 The councillor, who filed the complaint, willingly appears in the regional media that report the case. 
"Wspólnota". He also pointed out that Domaszowice was the most indebted commune in the district ${ }^{128}$. He called the commune a "socrealistic backwater", adding that already in the period of the People's Republic of Poland, it had been one of the national leaders in terms of communist party membership, and at present it was governed dictatorially, with its inhabitants brainwashed with "the propaganda of success" and lied to by the authorities. This critical assessment of the commune's reality caused the respondent to decide to return to politics and run for a seat in the council in 2014. In his words, it is "a fight for democracy" (Interview 12).

The representative of the commune authorities used a more delicate language in his description of the local political relations. In his opinion, it was one of the "more red communes" where the "eastern style of governance" dominated. Asked about the phenomenon of the commune leader's holding the office for many terms, he referred to the "old style of governance" consisting in making decisions individually by the leader, where "the leader decides about everything and assumes responsibility for it". According to the respondent, such a style of governance was received well by the inhabitants. He declared that he was aware of the increasingly fossilized character of the commune governance model and the necessity of modernizing the commune office, there were no areas available for new business undertakings, sports activities were practically non-existent, and there were no initiatives aimed at the integration of the whole community. He added that a more active attitude needed to be adopted in order to attract potential investors. Asked about the leader's passivity in these respects, he indicated some kind of standstill preventing him from adopting a more development oriented strategy. Answering the question about potential for establishing a youth council or a senior citizens council, the respondent said that such initiatives were not undertaken because the model of single person decision making was too strongly rooted in the commune. Thus, he showed a clear connection between the style of governance in the commune and the fulfilment of the particular criteria for the principle of equality in the governance

128 After the interview, the respondent sent the author data concerning his activity as a councillor and data concerning the commune's debt per inhabitant as published by the Ministry of Finance. According to these data, indebtedness per inhabitant in the communes of the district (in the third quarter of 2017) was as follows: Domaszowice - 1293; Namysłów - 1128; Świerczów - 1042; Pokój - 915; Wilków - 492. http:// samorzad.pap.pl/depesze/wiadomosci_centralne/179893/Zadluzenie-gmin--DaneMinisterstwa-Finansow-o-zadluzeniu-poszczegolnych-gmin (Accessed 3 July 2017). 
quality index. The commune leader regarded the potential establishment of such bodies as a threat to his authority and a risk of other groups' becoming stronger. According to the respondent, the commune was at a turning point because of the appearance of a new group of young voters (some of them became familiar with other standards while staying abroad) who expected governance based on "openness" and needed both changes and success (Interview 13).

The respondents also emphasized that such a manner of governing a commune turned out to be ineffective, which was proved by the commune's problems with modernization, absence of any ambitious plans ("no forward drive"), and the growing dissatisfaction of inhabitants expecting greater openness and modernity ${ }^{129}$. It should be noted that one of the objective measures of the commune's approach to the issue of development is the lack of an up-to-date development strategy. The latest such strategy covered the period of 2007-2013. Although it is no longer valid, it makes it possible to draw conclusions about the efficiency of governance as one of the priorities indicated in the document was the construction of a sanitary sewer system. However, it is necessary to take into consideration the fact that sewer systems are a problem in many small rural communes where population density and the lie of the land hinder the construction of such infrastructure. Therefore, it may be concluded that the absence of such a system does not have to be a reflection of the inefficient governance of a commune, but rather decision makers' rationality justified by a diagnosis of the costs of a whole undertaking. Nevertheless, the commune's Local Development Plan for the Years 2007-2013 presents the construction of a sanitary sewer system as the most important project to be carried out in the territory of the commune ${ }^{130}$. It means that the commune's strategic document identifies the project as a factual need of the local community (the plan was developed also on the basis of a survey conducted among inhabitants) and a local development priority. Such a diagnosis had already been established before 2007, and according to the data of the Central Statistical Office for 2015, in $20157 \%$ of the commune's inhabitants had access to a sewer system (while the average for the district was $53 \%$ ). Thus, the commune authorities failed to achieve the major objectives clearly identified

129 In the commune there is no cash machine, although there is a small bank. Thus, the only opportunity for obtaining cash in the amount of up to 300 zlotys is provided by the Dino supermarket.

$130 \mathrm{http}: / /$ www.static.domaszowice.pl/download/1655/plan_rozwoju_lokalnego_gminy_ domaszowice_na_lata_20072013.doc $+\& c d=1 \& \mathrm{hl}=\mathrm{pl} \& \mathrm{ct}=\mathrm{clnk} \& \mathrm{gl}=\mathrm{pl}$ (Accessed 25 May 2018). 
in their own development strategy. It should be added that in 2017 the commune acquired funding under the Operational Programme for the Development of Rural Areas for the construction of a sanitary sewer system ${ }^{131}$.

Another characteristic feature which can help in interpreting the commune's place in the ranking is a high level of political polarization, which hinders constructive cooperation aimed at solving common problems and undertaking initiatives for the development of the commune. The results of the latest local government elections (in which the commune leader won with the majority of 54 votes), the council session minutes, and information acquired during the interviews show a strong division in the local community and a culture of political conflict. The representative of the commune authorities emphasized that the local opposition was pursuing a policy consisting in "bashing", lies, undermining the credibility of commune office employees, and spreading gossip about their private lives. In his opinion, the opposition is not interested in compromise (Interview 13). Meanwhile, the opposition leader accused the authorities of authoritarian tendencies, unwillingness to accept criticism, and preventing access to information on the functioning of the commune office. He also mentioned problems that he had to cope with in connection with the organization of a meeting with a PiS Member of Parliament. There is no village hall in Domaszowice, therefore, a room for a meeting with an MP had to be rented from the commune office ${ }^{132}$. According to the interviewee, the office was deliberately protracting the whole procedure until the closure of the office's cash desk at 2:00 pm so that it became impossible to pay a fee for the use of the meeting room. Eventually, the fee was paid in a bank and the meeting was held as planned (Interview 12). It is difficult to settle unambiguously to what extent the provided information is true and to what extent it is the result of political emotions and squabbles. Nevertheless, it shows evidently the absence of mutual understanding and the mutual attribution of bad intentions. This model of relations among the main political groupings may result from the long-lasting monopoly of the arbitrary governance of the commune by the leader wary of dialogue accompanied by the gradual appearance of a politically inexperienced opposition attempting

131 https://bip.opolskie.pl/wp-content/uploads/2017/06/zal.-3798.pdf (Accessed 25 May 2018).

132 It also means that all events independent of the commune authorities have to be organized in the rooms of the commune office, which have to be formally rented from the office. This, in turn, allows the authorities to learn about the character of such events and to hinder their organizations. 
to make use of the available instruments of exerting pressure on the executive body (without having resources comparable to those in the leader's disposal).

The division into the supporters and opponents of the commune leader extends also to relations with the commune office because the leader's opponents assume that they will not be treated impartially. There are inhabitants who do not go to the commune office because they do not trust anybody there (Interview 11). The aforementioned circumstances may cause the maintenance and strengthening of strong relations between the office and a separate group of satisfied citizens with the simultaneous lack of any critical feedback from dissatisfied citizens, which may facilitate the continuation of the current governance model.

The last important issue shedding light on the quality of governance in the commune is the condition of the local community and its relations with the institutions of the commune authorities. The conducted interviews indicate that the level of interest in commune matters and readiness to act for the common good is rather low. This does not mean that there are no grass-roots initiatives, but they are usually limited to the level of individual village and are implemented with traditional rural social integration institutions such as a village leader, a voluntary fire service unit, or a village housewives' association. According to one of the village leaders, "everybody lives for themselves". In a village of 400 people, a recent village meeting was attended by 15 people. The meeting concerning the possibility of selling alcohol in the village was attended only by the village leader and a representative of the commune office. According to one village leader, "people are self-contained" and leave local matters to the commune leader, council, and village leaders (Interview 14). At the level of villages, the attitude is that the commune is responsible for solving all problems - inhabitants push the whole weight of this responsibility onto commune authorities. Attendance at hamlet meetings is very low, despite the fact that such meetings are devoted, among others, to the distribution of funds for the financing of local undertakings. ${ }^{133}$. In the particular villages, the level of integration is also low; loyalty and mobilization are determined by familial criteria. There is no sense of a self-governing local community or readiness to make small sacrifices of one's interests for the benefit of the other inhabitants and the commune budget. An example given by the representative of the authorities is school transport in the commune. Inhabitants would like the

133 According to the budget resolution for the year 2017, the village fund is to amount to 179,000 zlotys. Depending on a village, amounts available for individual projects oscillate between 8,000 and 30,000 zlotys (http://www.bip.domaszowice.pl/download/ attachment/6119/uchwalaxxii13420162016-12-29-w-sprawie-uchwalenia-budzetugminy-na-2017-r.pdf accessed 23 May 2018). 
school bus to pick up each child individually from his/her home; they demand a bus stop in every village so that they do not have to walk far to catch a bus, but do not want to take into consideration the procedural (the opening of a bus stop), temporal, and financial costs of such solutions. According to one of the respondents, many inhabitants are not able to look at their commune from a bird's eye view and grasp the whole self-governing community; because of particular interests, they want solutions which, in the long run, will turn out to be disadvantageous for them because of related costs (Interview 13).

Thus, the commune under analysis is divided into social microworlds dominated by identification with one's own village. An interview with one of the respondents indicates that the only plane of integration among the villages is the commune harvest festival during which the representatives of the particular villages decorate various places in Domaszowice, which constitutes a basis for "healthy competition". Activity at the village level depends to a considerable extent on local leaders who mobilize inhabitants. However, the most dynamic initiatives are the effect of cooperation among an active village leader, voluntary fire service units, and village housewives' associations. As far as the role of councillors is concerned, they act as middlemen between villages and the commune authorities. Defending their villages' interests, they simultaneously strengthen inhabitants' village-based identities (Interview 11). An important point is that village leaders often do not perceive their functions as political. The respondent (village leader) is not interested in being a part of local politics, adopting an attitude of a safe distance to politics because "if you are not careful, you can get burned" (Interview 14). Thus, politics is perceived as something reserved for formal political institutions, i.e. the commune leader and the commune council, and involvement in politics is regarded as a potential threat.

It appears that this state of inhabitants' being distanced from local politics, failure to identify with the local community, and placing responsibility for everything on the commune authorities can be explained by reference to a few factors. On the one hand, we can observe features characteristic of small, agricultural and rural communities focused on their own interests, indifferent to matters from outside their village, simultaneously obsequious towards and mistrustful of local authorities. In an interview with one of the local businesspeople who lived in a big city before settling down in the commune, Domaszowice is described as a place where "democracy is the village leader" and his own urban origin is still a barrier to integration with the local community (Interview 15).

Another important factor emphasized particularly by the representatives of the commune authorities is the borderland origin of a large part of the commune's population. According to them, the villages dominated by the population 
coming from eastern Poland are characterized by more intense local ties rooted in familial structures than the villages dominated by settlers from central Poland (they refer to "clannish identities"). Settlers coming from the former Eastern borderlands still create closed communities where in time one surname starts to dominate and there is no lack of endogamous relationships. Thus, what we witness is villages characterized by what Robert Putnam referred to as binding social capital, where strong intra-group ties coexist with a lack of ties to the outside world. According to the respondents, coming from the former Eastern borderlands also influences the lower quality of managing one's own property, the state of tidiness in a village, and the aesthetic qualities of households - there are still visible differences between the villages inhabited by the descendants of settlers coming from eastern Poland and those from central Poland (Interview 11; Interview 13).

The last factor explaining the low quality of the civic society is the already discussed model of one-man commune governance. It can be supposed that the specific character of the long-lasting politics of the commune leader which was a reproduction of the power exercise models inherited from the times of socialism facilitated the petrification of the aforementioned attitudes. The local population was being accustomed to the top-down and centralized formula of governance in which a community's bottom-up mobilization was perceived as something redundant or a threat to those in power. It is necessary, however, to refer to one more feature characteristic of Domaszowice which weakens the argument of a low level of participation, namely a high voter turnout in successive local government elections.

In comparison to the other communes in the district, Domaszowice has the highest voter turnout in local government elections. Although not so big, this advantage is also true in the case of parliamentary elections. Taking into consideration the commune's position on the governance quality scale, we can observe an interesting case showing that a high voter turnout is not always an indication of a high quality of governance. In this case, the high voter turnout can be explained by the unique character of local social and political relations connected with the commune leader's power of mobilization and the fact that he has held the office for a long time. Thus, the question arises: How is it possible to hold power for many terms of office in the circumstances of a low quality of governance?

Firstly, it seems that during the many terms of office the commune leader managed to create a well-functioning system of connections with the local electorate. One of the methods of developing such connections was using public resources and distributing them in accordance with the logic of patronage and 
clientelism relations. The interview with the representative of the commune authorities indicates that the commune has a clear pyramid-shaped political hierarchy comprising the commune leader, the local priest, the village leaders, and the voluntary fire service unit, and ensuring support for the commune leader. One of the instruments of strengthening this structure was the distribution of the commune budget, e.g. a considerable percentage of the budget was allocated to the local voluntary fire service units ${ }^{134}$, which constitute a strong election base for the commune leader (Interview 13). The representative of the opposition also referred to the use of the commune's resources. He said that it was one of the methods of rewarding for loyalty and punishing for the lack of it. In his opinion, the uses of available communal resources are more diversified; they include employment in the commune office and its subordinate entities (according to one councillor, the result of any competitive procedure is obvious from the very beginning), dealing with matters in the commune office (disloyal persons have to cope with administrative hindrances, the course of their matters is delayed), and public works as an instrument of distributing employment opportunities in the commune (Interview 12).

The aforementioned newsletter entitled "Gazeta Gminy Domaszowice" constitutes an example of using the commune's resources to create a positive image of the commune office. The newsletter fulfils important functions in the lives of inhabitants as an instrument of providing information on communal matters and integrating the local community. Its circulation is 1000 copies so that every household could get its own copy (Interview 11). Simultaneously, an analysis of the first eight issues of the newsletter published from March 2017 to June 2018 shows that it is an instrument for promoting the commune leader and

134 In one of the interviews, the commune leader states that, among the communes of the Namysłowski district, Domaszowice allocates the largest percentage of its budget to the functioning of the fire protection system, i.e. approximately $2.5 \%$ (in 2017 it was 336,000 zlotys). The commune leader participates in reporting meetings of the local voluntary fire service units and has a very good opinion of firemen and cooperation with their units. Simultaneously, in the interview he responds to some councillors' suggestion that the voluntary fire service units should undergo reviews and assessment, indicating that the commune leader can exercise no control over their structure or activities because formally, they are independent associations. It means that there appear critical opinions about the local voluntary fire service units, and the commune leader clearly plays the role of the protector of their autonomy and good reputation. http://domaszowice.pl/download/attachment/6630/gazeta-gminy-domaszowice-nr16-2018-wyd-styczen-luty.pdf (Accessed 26 May 2018). 
officials subordinate to him. Seven of the eight issues feature an interview with the commune leader, and every issue contains a page (usually page 3 ) dedicated to the presentation of the deputy leader's opinions. Opinions of local activists are also presented in the newsletter, and they have one page in every issue at their disposal. However, such activists are always people related to the commune authorities, e.g. SLD councillors, village leaders, the chairperson and chiefs of the voluntary fire service units, and the chairperson of the local sports club. In five issues of the newsletter there is no information on the opposition in the commune council, and in three issues there is criticism aimed at the opposition councillors.

Besides the distribution of resources as a method of building local support, it is impossible to disregard emotional ties between the commune leader and his supporters. It seems that some of his advocates support him because of his deep roots in the local community, personality traits, and ability to build personal relations with people ${ }^{135}$. Back in the times of the People's Republic of Poland, in the capacity of the first secretary of the local unit of PZPR, he was regarded as a person who could arrange important things for local farmers, e.g. spare parts for tractors. This strategic position and personal charisma ensured that he was held in high esteem in the local community. Representing the peasants' party PSL, his main rival in commune leader elections (in the years 2002, 2006 and 2010) already in 2004 stated that the commune leader "had perfectly mastered techniques of social engineering", implying that his opponent from Solidarity did not know "how to talk to people" (Zyzik 2004). In an interview, one of the village leaders, a supporter of the commune leader, declared that he voted for the commune leader because he "knew him" and the leader "was from here" (Interview 14). One of the inhabitants, a supporter of PiS, emphasized that the commune leader was a polite man who said hallo to everybody, had lived in the commune for a long time, and was always ready to help; an example of "one of us", whose friends and acquaintances always voted for him in elections (Interview 16). Thus, the commune leader is defined as a fellow-countryman who skillfully builds personal relations constituting social capital which is converted subsequently into political capital during elections. This is a case of so-called prescription annuity whose important components are the recognizability of a local leader and the

135 The tab "Commune leader's profile" on the commune's Public Information Bulletin website informs the reader that the leader has a degree in sociology, and has been connected with the commune of Domaszowice since 1976. Privately, he loves "nature, forests, and gardening". 
fact that people get used to a leader who has held an office for a few terms in a row (Żurek 2012: 176-177).

The final factor explaining the examined phenomenon of the commune leader's holding the office for many terms is the long-lasting absence of any attractive and strong alternative. It results also from the features discussed above such as the leader's style of governance, available power consolidation tools, potential sanctions against political opponents, and the weakness of the local community. According to one of our respondents, such an arrangement has functioned for a long time because the majority of inhabitants do not want to get involved in any activities being convinced that "after all, nothing will come out of it". The commune has no alternative leaders, some groups are interested in maintaining the status quo, and others are afraid of sanctions which the commune leader may impose on them (Interview 12). On the other hand, according to a representative of the authorities, in the commune there is no opposition competent in terms of knowledge, language and "visual imagery" (Interview 13).

The above interpretation of the phenomenon of holding an office for many terms complements a description of factors responsible for the commune's low position on the governance quality scale. It shows the dynamic character of selfstrengthening relations among governance styles, holding an office for many terms, and governance quality. Allowing him to hold the office of commune leader for many terms, the governance style used by the leader simultaneously resulted in a rather low level of governance quality (at least in the light of the indexes proposed here). Nevertheless, there remained a group of the beneficiaries of this style of governance which was large and organized enough to ensure the reproduction of the existing power structure guaranteed by the commune leader during the periods of electoral mobilization. At the same time the number of those dissatisfied with the existing social and political relations remained relatively stable. Passive and silent for a long time, only in the recent years did it produce a stronger and coherent political representation by providing support to the local structures of $\mathrm{PiS}^{136}$.

136 A party which, similarly to the SLD, attracts people experiencing social exclusion and demanding a moral cleansing of public life (Gdula, Dębska,Trepka 2017). 



\section{Conclusions}

The starting point for the conducted research was the authors' assumption that there existed differences in the quality of governance between the western, more ethnically homogeneous part of the Opolskie province, and its south-eastern part inhabited by the German and Silesian minority. This assumption had the character of common-sense knowledge determined by stereotypical convictions functioning in the consciousness of many inhabitants (as well as regional political elites and journalists) of the province and concerning its division into a poorer western part and a more successful eastern part, which is under a considerable political, economic, and cultural influence of the German minority. At the perceptual level, this division was strengthened by differences in the aesthetics and development of rural areas between the western and eastern parts of the region. This dissimilarity stirred imagination, resembling the Weberian concept of Protestant values and stereotypes about German order and work organization, and raising the question about the impact of the German-Silesian factor on the quality of governance at the commune level. Besides the influential book by Robert Putnam, it was to a considerable degree everyday experience of the local reality that motivated us to formulate a research problem whose focus was possible relations between ethnic diversity in the province and the quality of governance in its particular communes.

We were interested in finding answers to the question whether the quality of governance would be factually higher in ethnically diversified communes than in ethnically homogeneous ones. We also wanted to find out what possible connections between the existence of the German and Silesian minority and quality of governance consisted in. Based on everyday experience, our hypothesis was that the quality of governance would be higher in communes characterized by ethnic diversity. We also assumed that it would result from the minority's sense of separate identity and political interests that constituted a force mobilizing minority members to spare no effort with respect to the exercise of power. In order to verify the proposed hypotheses, we carried out the research in two stages. Conclusions drawn from both of them are presented in the subsequent paragraphs.

The conducted quantitative analysis indicates that there are no clear relations between ethnic diversity and the holistically perceived quality of governance, i.e. in light of our data, governance quality in ethnically diversified communes is not higher than that in the other communes. Speaking of the holistically perceived 
quality of governance, we mean the total value of a particular commune's governance quality index proposed by the authors and based on five principles. Thus, it can be concluded that the authors' hypothesis was not confirmed. However, if we take into consideration the particular sub-indexes of governance quality and their relations to ethnic diversity identified in both the qualitative analysis and the case studies, it seems that ethnic diversity plays a certain role. In comparison to the ethnically homogeneous communes, the ethnically diversified ones are characterized by a higher level of participation. The qualitative analysis shows that it is first of all the effect of the functioning of active non-governmental organizations, with the special role of the Social and Cultural Association of Germans as a multilevel, province-wide structure with strong foundations at the level of communes and villages in the form of commune boards and German friendship circles. The local structures of the Social and Cultural Association of Germans constitute a platform for local integration in the social, cultural, and political dimensions. The higher level of participation may also result from the minority's greater attachment to little homelands whose strength results from the fact that the minority comprises the autochthonous population which lived in the region before World War II and which refers to the pre-war period (through the continuity and maintenance of collective memory, the institutions of the economic, religious, and cultural life, and symbolic politics). Accepting the findings made by Danuta Berlińska in her research conducted in the 1990s (Berlińska 1999), we also do not rule out that the awareness of belonging to a minority is a force encouraging people to be more active at the level of local governments. It is believed that it is the local government level that creates the greatest opportunities for protecting people's interests and rights, and strong rootedness in local power structures guarantees such protection.

It should be also remembered that in one of the variants of the analysis of correlations between governance quality and ethnic diversity in which only rural communes were taken into consideration, the interdependence between the variables was clearly visible. Nevertheless, this topic did not draw special attention in the qualitative analysis mainly in view of the fact that the quality of governance in rural communes had turned out to be evidently worse than that in rural-urban communes. It is highly probable (which can be concluded from an analysis of the tables and graphs presented in Chapter IV) that this interdependency is determined by the much higher level of participation in the ethnically diversified communes.

The phenomenon of high participation occurs also in the community of Walce, where the overall quality of governance is low. An analysis of this case allowed the authors to reach the conclusion that at a local level, strong 
participation might have negative consequences for the assessment of the quality of governance in the other dimensions. The strength of the minority's local institutions facilitating participation may lead to the monopolization of a local political scene and the weakening of such classical accountability mechanisms as regular and competitive elections. It can also lower the level of openness because the strength of institutional and informal connections between local authorities and a local community (dominated by the representatives of the minority) is great enough to guarantee minority members access to the local political system and to weaken the need to use more formalized and transparent solutions. Thus the quantitative data and the case studies show that ethnic diversity is not a factor influencing unidirectionally the holistically perceived quality of governance, but that its character is rather ambivalent, i.e. depending on a governance quality dimension, it may generate positive or negative phenomena. In order to verify this observation by means of the quantitative data, having completed the qualitative analysis, we conducted an analysis of correlations between the dimension of participation and the dimension of accountability. In the group of the rural communes, we observed a negative, although weak, correlation $(-0.172 ; n=35)$. In the whole sample $(n=60)$, we found no interdependencies between either these dimensions or participation and openness. However, in our opinion, the described mechanism is important and interesting enough for us to recommend the continuation of research in this area at the level of small rural communes.

Despite the fact that the conducted research did not confirm the proposed hypothesis, the added value of the performed analysis is the fact that the quality of governance in the ethnically diversified communes is not worse than that in the homogeneous ones. Such a possibility was implied by the literature review presented in Chapter I. The majority of research indicates a negative correlation between ethnic diversity and phenomena such as social trust, social cohesion, the strength of the civic society, and economic equalities. We did not find the multi-ethnic communes to be characterized by a high degree of social polarization or an open inter-group conflict. Nevertheless, we regard the case of the Opolskie province as, in a sense, unique. The factors that should be taken into consideration in this context include the following:

- a relatively short cultural distance between the particular groups;

- a legal regime guaranteeing the representatives of all studied groups Polish citizenship, equality before the law, and additional guarantees for the German minority under the Act on National and Ethnic Minorities and Ethnic Languages; 
- a good economic status of the majority, which fulfils the role of an antidiscrimination mechanism.

Furthermore, we would like to draw attention that what distinguishes Opole Silesia from other multi-ethnic regions around the world is the fact that in a relatively short period of time, i.e. approximately forty years after the war, the autochthonous population became dominated by the immigrant population with respect to both the numerical strength and the roles played in the region's politics, culture, and economy.

If we were to try to indicate determinants with the greatest influence on the quality of governance in the communes under examination, we could refer to the features common for Paczków and Kolonowskie, which at the same time do not occur in Walce and Domaszowice. These features are the tradition of employment in industrial enterprises and consequent urbanization manifesting itself in the existence of a small urban centre. Another feature is the existence of competitive, but simultaneously conciliatory, political groups in a commune. It should also be noted that the communes with the highest values of the governance quality index aspire to be tourist centers and take effort to use their tourism development potential as an important element of the local economy and their own identity. These characteristic features cannot be found in Domaszowice or Walce1. At this stage of the research we are not able to provide an exhaustive and fully reliable answer to the question about the nature of the influence of these features on the quality of governance, the weight of each of them, or mutual relations among them. In the case of some determinants, particularly the issue of a competitive and conciliatory political scene, we face the problem of the direction of causal determinants. It seems that we can assume that the traditions of industrialization and urbanization as well as the existence of objective (i.e. geographical and architectural) foundations for the development of tourism are the primary, structural determinants of a higher quality of governance. However, in the case of a competitive and conciliatory political scene, we can conclude that it can be not only a cause but also a result of a high quality of governance.

We do not know how exactly the fact of industrial traditions and the existence of a small urban centre can translate into a higher quality of governance. The sociological imagination suggests that industrialization and urbanization should change the character of interpersonal relations in a given area, weakening local particularistic interests and simultaneously broadening the scope of interpersonal contacts in parallel to the appearance of larger urban centers. The existence of the industrial economy may have influenced the wealth of the local community, its life style, and expectations of the local elite. The presence of industrial 
enterprises in the local landscape required also that the commune authorities provide necessary administrative services and professional personnel. Maybe the sociological fact of a small town as a centre of political and cultural integration facilitates more professional and open local administration. Also, political competition that does not exclude the possibility of supporting particular solutions and projects pursued by those in power appears to be a source of dynamics in local politics, constituting an alternative to local authorities and an entity supervising their actions. Focused naturally on people and institutions from outside a commune, tourism requires openness, a professional approach, and coordination/cooperation among local authorities and all grassroots entities interested in attracting tourists to their locality. At this stage of the research these are only interpretations that constitute inspiration for the formulation of further hypotheses and more systematic research on the determinants of the quality of governance at a local level.

What deserves separate attention is the role of commune leaders/mayors. The conducted case studies showed that their actions were of considerable importance from the perspective of governance quality. We are aware that this conclusion is open to the charge of banality because their special position results from the legal and political roles they play on the local political scene. What dominates in the Polish local government system is the model of a strong mayor, hence it is only natural that they have considerable impact on the standards of governance at the commune level. But the case studies show that a strong position in a local political system may lead to different consequences for the quality of governance because another thing that counts is a style of governance represented by the head of an executive body. Although commune leaders/mayors function in an institutional environment that imposes certain limitations on them, the cases of Paczków and Domaszowice show that they are able to initiate or block numerous initiatives, thus influencing the shape of the local public space. They may pursue more participatory agendas oriented towards risky investment projects or strategies aimed at the concentration of power and avoidance of large and risky projects. The case of Kolonowskie indicates also the importance of their social capital, i.e. connections with the structures of the local government at the provincial level that may favor the development of their communes. This leads to the conclusion that a leader's personality and experience considerably influence the quality of local institutions. Making proper decisions, voters can seriously influence the quality of governance, but it is also possible that after they have made their choices the quality of governance will depend too much on the personality and management style of just one person. 
What is also very important is conclusions concerning the methodological aspects of the conducted research. At the particular stages of the research process there appeared dilemmas and problems that have to be taken into consideration in an assessment of the research results presented here. Undoubtedly, the major problem that we had to address was a method of measuring governance quality. This problem is described in detail in Chapter II and the annex. Nevertheless, in this part devoted to conclusions, we can supplement this description on the basis of the knowledge which we had not had at the stage of developing the governance quality index, and which we acquired in the course of the case studies. They showed once more how difficult it was to select measures that could fully reflect the application of the good governance principles in small rural communes. The case of Walce showed that the sub-indexes of openness and accountability were not able to capture governance mechanisms characteristic of a small commune and corresponding to the idea of good governance. This does not mean that these sub-indexes are deprived of any diagnostic value, but rather that they refer to official manifestations of openness and accountability, leaving aside more subtle and difficult to quantify mechanisms. We are also willing to risk the hypothesis that if the governance quality measuring methodology were based on the inhabitants' perception, the places of the particular communes on the governance quality scale would be different. Maybe a representative survey conducted among the inhabitants of Walce and Domaszowice would show that a considerable part of them perceive, for example, their local authorities as open and accountable, and local relations as egalitarian. It seems, however, that it is a manifestation of a more general problem that those studying the social reality have to deal with, namely discrepancies between the imagined world and the sphere of objective conditions/processes. The authors are aware of the methodological weaknesses and problems of the presented research undertaking; therefore, they try to provide possibly the most exhaustive and detailed description of the applied research methodology. Thus, the presented research results should be interpreted with some scientific detachment taking into consideration the problems facing the researcher measuring the quality of governance in small communes whose primary objective is to verify formulated hypotheses empirically despite methodological difficulties identified during the course of the research process. 


\section{Annex 1}

\section{A table of the governance quality indexes}

\begin{tabular}{|c|c|c|c|}
\hline index & $\begin{array}{l}\text { period to } \\
\text { which data } \\
\text { refer }\end{array}$ & data source & sub-index \\
\hline $\begin{array}{l}\text { 1. The number of } \\
\text { non-governmental } \\
\text { organizations in } \\
\text { the commune per } \\
10,000 \text { inhabitants }\end{array}$ & 2016 & $\begin{array}{l}\text { National Court Register, } \\
\text { communal registers } \\
\text { of non-governmental } \\
\text { organizations, communal } \\
\text { representatives for NGOs }\end{array}$ & participation \\
\hline $\begin{array}{l}\text { 2. The number of } \\
\text { library members per } \\
1000 \text { inhabitants }\end{array}$ & 2015 & $\begin{array}{l}\text { Local Data Bank of the } \\
\text { Central Statistical Office }\end{array}$ & participation \\
\hline $\begin{array}{l}\text { 3. The average mark } \\
\text { in the junior } \\
\text { secondary school } \\
\text { examination in } \\
\text { the knowledge of } \\
\text { society and history }\end{array}$ & 2016 & $\begin{array}{l}\text { Regional Examination } \\
\text { Board }\end{array}$ & participation \\
\hline $\begin{array}{l}\text { 4. Funds from the } \\
1 \% \text { mechanism } \\
\text { acquired by } \\
\text { the commune's } \\
\text { public benefit } \\
\text { organizations per } 1 \\
\text { inhabitant. }\end{array}$ & 2015 & $\begin{array}{l}\text { Ministry of Labour and } \\
\text { Social Policy }\end{array}$ & participation \\
\hline $\begin{array}{l}\text { 5. The percentage of } \\
\text { votes cast for voters' } \\
\text { election committees } \\
\text { in relation to the } \\
\text { total number of } \\
\text { votes cast in the } \\
\text { commune council } \\
\text { elections }\end{array}$ & 2014 & State Electoral Commission & participation \\
\hline
\end{tabular}




\begin{tabular}{lll}
\hline index & $\begin{array}{l}\text { period to data source sub-index } \\
\text { which data } \\
\text { refer }\end{array}$ \\
\hline
\end{tabular}

6. The percentage term of Local Data Bank of the equality of women in the office: 2014 Central Statistical Office commune council. $\quad-2018$

7. The percentage February analysis of communes' equality of women holding $2017 \quad$ Public Information key positions in the Bulletins and websites commune office

8. The activities of the July 2017 CAWI

equality youth council

9. The activities of July 2017 CAWI equality the senior citizens council

10. The degree of the 31.12.2015 The Regional Social Policy equality poverty risk Centre in Opole

11. The commune's own income per 1 Local Data Bank of the efficiency inhabitant

12. Investment expenditures from 2015 Central Statistical Office the commune budget per 1 inhabitant 13. The percentage of 2015 The Regional Social Policy efficiency people using social assistance services on a long-term basis in relation to all people receiving social benefits

14. Expenditures on 2014 Report: Swianiewicz P., efficiency public administration per 1 inhabitant Centre in Opole Łukomska J., Oszczędny

2015

The Central Statistical efficiency
Office

urzad. Ranking wydatków na administracje - 2014 r., Periodical "Wspólnota" 


\begin{tabular}{lll}
\hline index & $\begin{array}{l}\text { period to data source } \\
\text { which data } \\
\text { refer }\end{array}$ & sub-index \\
\hline
\end{tabular}

15. The commune's July 2017 CAWI efficiency usage of one of the three quality management systems.

16. The existence of a local media organization that is not controlled by the commune authorities 17. The publication of internal inspection reports in the Public Information Bulletin for the years 2015-2016

18. The number of candidates for the position of commune leader/mayor in the 2014 local government elections.

19. The publication of 2 June the councillors' and 2017 the commune leader's property statements in the Public Information Bulletin before 2 June 2017. 20. The percentage of 2015 Local Data Bank of the accountability the councillors with higher education.

21 . The commune's responding to the April 2017 analysis of communes' Public Information Bulletins

April 2017 analysis of data available in accountability the internet based on key words

accountability

2014

State Electoral Commission accountability analysis of communes' Public Information Bulletins accountability questionnaire by the set deadline, i.e. 21 July 2017 


\begin{tabular}{lll}
\hline index & $\begin{array}{l}\text { period to data source } \\
\text { which data } \\
\text { refer }\end{array}$ & sub-index \\
\hline
\end{tabular}

22. Easy access to and August

analysis of Public

openness

availability of a valid 2017

annual programme

Information Bulletins and

of cooperation with

internet content

non-governmental

organization (for

the year 2017) in the

Public Information

Bulletin or on the

commune office's

website

23. The number of

2016

CAWI

openness

non-governmental

organizations which

have submitted

comments on the

programme of

cooperation with

non-governmental

organizations for the

year 2017
24. The passing
July 2017 CAWI
openness
of a resolution
determining the rules
and procedures of
social consultations.
25. The publication
15 August
analysis of communes'
openness
of commune council 2017
Public Information
session minutes for
Bulletins
the year 2017 in the
Public Information
Bulletin 


\section{Annex 2}

\section{A detailed description of the particular governance quality indexes}

\section{Participation sub-index}

\section{The number of non-governmental organizations in the commune per 10,000 inhabitants}

The institutional power of associations is a measure used frequently in research on social participation. This index caused the fewest doubts. According to Robert Putnam "civic associations contribute to the effectiveness and stability of a democratic government (...) because of their both «external» impact on particular members and «external» impact on wider social groups. (...) A dense network of secondary associations both embodies effective social cooperation and contributes to it" (Putnam 1995: 137-138). Nevertheless, gathering reliable data turned out to be rather problematic. The National Court Register is the basic register of foundations and associations. But it is a "register of birth" of such organizations rather than a reliable tool that can be used to verify the number of factually functioning entities. Collecting data, we compared the data obtained from the National Court Register with data coming from other sources such as communal or district registers of non-governmental organizations, internet databases, and information provided by the representatives of the particular communes. District registers are maintained within the scope of administrative supervision of the heads of district offices over organizations. Communal registers are not maintained obligatorily, however, they are sometimes placed on commune offices' websites within the scope of the duties of a communal representative for non-governmental organizations. Furthermore, a database of non-governmental organizations functioning in the Opolskie province has been established recently. It is available at the following address: ngo.opolskie.pl. The last source of data was requests for the provision of public information, i.e. the number of factually functioning entities, sent to the communal representatives for non-governmental organizations. None of the aforementioned sources provided us with information that was $100 \%$ reliable. Therefore, we conducted a verification consisting in removing from the broad register of non-governmental organizations those entities that were not recorded 
in other sources. In doubtful cases we conducted an additional search for the traces of the activities of a particular organization such as a website or a Facebook profile. Eventually, we managed to establish the number of non-governmental organizations functioning in the Opolskie province at 2258 as compared to 3058 entities registered in the National Court Register. In our opinion, such a considerable difference justifies the necessity of verification.

The necessity of verification resulted also from a narrower definition of a nongovernmental organization adopted for our purposes. First of all, it should be emphasized that the register of associations includes also entities that are usually not identified with the so-called third sector, i.e. health care centers, trade unions, or agricultural machinery sharing cooperatives. Many doubts arise over the classification of voluntary fire service units and sports clubs as nongovernmental organizations. The former are accused of having their roots in the People's Republic of Poland and excessively close relations with local authorities, while the latter are perceived as having nothing to do with active citizenship and no interest in local matters, being in fact businesses operating under the aegis of non-profit organizations (Opioła 2017). On the other hand, there are strong organizations which function on the basis of active field structures and large numbers of members and volunteers, which are entered in the register as a single entity. Consequently, we decided to exclude organizations that are not usually associated with non-governmental organizations (health care centers, trade unions, political parties, agricultural machinery sharing cooperatives) and sports clubs as they do not fulfil our definition of civil society. At the same time we included the regional units of The Social and Cultural Association of Germans in Opole Silesia, which is an organization with the largest number of members in the province (over 30,000 members the majority of whom pay membership fees). We also included voluntary fire service units in the register of non-governmental organizations. We regard the argument concerning their communist origin as illogical and indicating a political character of the debate rather than attention to analytical precision. Despite their obvious connections with local authorities as well as politicizing (or even dependence on a particular political party), we consider fire service units as neighborhood watch organizations which, in many villages, are the only institutions - besides the Church - of communal life.

\section{The number of library members per 1000 inhabitants}

The functioning of communal public libraries entails a number of positive consequences from the point of view of local participation. Libraries provide citizens with free access to information and culture, thus multiplying the intellectual 
capital and social capital of local communities. They also fulfil other social and cultural functions: they are meeting places, venues for cultural events or various activities for children and adults (Głowacka 2011: 2017-230). We were interested not so much in the very fact of the functioning of libraries as in their usage by commune inhabitants. Many studies conducted in the recent years prove that the level of general readership, and particularly press readership, correlates positively with so-called civic literacy $y^{139}$ understood as skills of participating in public life. For example, people reading newspapers participate in elections more often than those who do not and have a better knowledge of political issues (Gentzkow et al. 2011; Milner 2002; Ipsos MORI 2010 $)^{140}$. Since we have no results concerning readership at the local level, we decided to use another index, i.e. the number of library readers per 1000 commune inhabitants, which is published by the Local Data Bank of the Central Statistical Office. For us, the number of persons who use a library during the course of a year is a measure of interest in public affairs as well as skill of using public services. Indirectly, this index provides also some information on political participation (correlated with press readership) and the strength of local social ties (the tendency to use public space).

\section{The average mark in the junior secondary school examination in the knowledge of society and history}

This index is to reflect the level of young people's knowledge and skills important from the point of view of civic participation, e.g. identification with the rules and requirements of a democratic state. We selected the junior secondary school examination, and not the senior secondary school examination, for two reasons. Firstly, young people attending senior secondary schools have a greater choice of schools outside the place of their permanent residence, which results in the outflow of the most ambitious pupils to better schools in larger towns and cities. Junior secondary schools are covered by the zoning system. Secondly, the most important comparative research on pupils' competencies and skills conducted, among others, by OECD (the PISA research; OECD 2012), focuses on young

139 We use the notion of social proficiency, which was coined by Maciej Dobras. But it seems that it would be more adequate to speak about civic proficiency (Dobras 2016: 681-689).

140 Slightly different conclusions can be drawn from the research conducted by C.J. Pattie and R.J. Johnston: press readership does influence a voter turnout and knowledge of politics, but increases in the level of readership does not translate into a further rise in a voter turnout (Pattie, Johnston 2003). 
people aged 14-15. From the available data, we selected the result in history and the knowledge of society, which have the greatest influence on young people's attitudes and skills important from the point of view of participation.

\section{Funds from the $1 \%$ mechanism acquired by the commune's public benefit organizations per 1 inhabitant}

We want to use this index to measure charity (with the reservations below) and the factual strength of civic organizations. The one-percent mechanism allows taxpayers to donate $1 \%$ of their personal income tax to a freely selected public benefit organization (PBO). The status of a $\mathrm{PBO}$ can be acquired by non-governmental organizations (as well as organizational units of churches and religious associations, and also non-profit companies) after fulfilling certain requirements. Although in fact this mechanism has nothing in common with charity (Perkowski 2011) - a taxpayer does not donate their own funds, but a part of tax that they have to pay otherwise - research indicates that people who decide to donate $1 \%$ of their tax to a selected organization are motivated by the willingness to help those in need ${ }^{141}$. However, the most important thing is that available data show that almost $80 \%$ of those who donate $1 \%$ are of the opinion that it is important for the building of civil society (Piechota 2010).

Data concerning revenue from one-percent donations are not presented with respect to particular communes, but they can be obtained relatively easily. There are two methods. One of them consists in obtaining information on the amounts of one-percent donations made by the taxpayers living in a particular commune from tax offices; alternatively, it is also possible to acquire data concerning the percentage of taxpayers who have made such donations. We obtained such data under the public information access procedure from nine tax offices (out of 11 tax offices functioning in the province). The other method provides for obtaining information on amounts donated for the benefit of particular PBOs (relevant reports are available on the website of the Ministry of Labour and Social Policy), and subsequently allocating them to communes and calculating the amount of donation per one inhabitant of a given commune. We used the latter method in the calculation of our index. Its advantage over data provided by tax offices

141 This can be inferred from the results of the research carried out by Grażyna Piechota in the Sląskie province. Among the respondents who admitted making a one-percent donation, the most frequent reason for such a decision was willingness to provide assistance: "I want to help, and it doesn't cost me anything" (49.65 \%), (Piechota 2010). 
consists in the possibility of checking the potential of local PBOs and their skills in acquiring funds and developing a network of "donators"142.

\section{The percentage of votes cast for voters' election committees in relation to the total number of votes cast in the commune council elections}

Because of the unique character of the Opolskie province, we were not able to regard data on a voter turnout, which are usually used as a measure of participation, as reliable. Looking for an index that could be a good substitute for a voter turnout in the dimension of local political participation and responsibility for the community, we decided to take into consideration the strength of election committees established by voters in local elections. The literature on the subject presents the view according to which the party-based character of local government institutions, especially at the local level, is not a desired phenomenon from the perspective of the quality of governance, self-government, and the strength of local communal ties within the framework of the so-called new political culture. The idea of strengthening a local civil society motivated the authors of the electoral law, which, in the case of local government elections, provides for the possibility of registering election committees by entities other than political parties. Thus, non-partyism is the feature of a local democracy (Gendźwiłł 2011). This results to a considerable degree from the weakness of institutional political parties "in the field", but also from conflicts of interest (a party's interests do not have to be coincident with those of a local community). According to the concept of new political culture, political parties, especially at the local level, "do not perform well as public life institutions when society is moving towards post-materialistic values", and their "representatives holding local power can be less innovative" (Ibidem: 17). Of course, we often witness electoral camouflage: because of the low level of trust in political parties, party candidates run for offices under the aegis of local organizations or as private persons; nevertheless, local governments are regarded as bastions of non-partyism (Ganowicz, Opioła 2017). We are of the opinion that the higher percentage of votes cast for voters' election committees is the manifestation of inhabitants' greater ability to undertake bottom-up political initiatives and greater responsibility for the local community.

142 It should be noted that although the most probably local PBOs receive one-percent support primarily from the inhabitants of their respective communes, they can receive donations from all over Poland. 


\section{Equality sub-index}

\section{The percentage of women in the commune council}

This index indicates the level of women's political representation in a commune council, thus it is a measure of gender equality. As a measure of equality, it is based on the assumption that the share of women in a commune council is a reflection of their position/strength in the local community and makes it possible to draw conclusions about how their interests are represented. Data concerning the percentage of women in the particular commune councils are provided by the Local Data Bank of the Central Statistical Office. It is possible to indicate two basic weaknesses of this index. The first weakness is connected with the fact that it can be also classified as an index of participation or openness, but it is a general problem of many indexes, which was described in Chapter II. Another weakness is the lack of the possibility of drawing conclusions about factors responsible for the level of women's representation in commune councils. It has already been mentioned that there is an assumption concerning women's strong positions in communes as a factor determining the level of their representation, but it is of an a priori character. The index shows only the factual condition, but it does not prove that, for example, a small representation of women in a commune council is a measure of discriminatory practices in local elections or a low level of social capital. What causes a particular level of women's representation in a given commune council would require a thorough empirical analysis of a concrete commune.

\section{The percentage of women holding key positions in the commune office}

Similarly to the previous one, this index indicates the level of political representation in executive authorities. It is a complementation of a picture of gender equality in a commune based on an analysis of who holds managerial and executive positions. The selected configuration of positions is the same for all communes: commune leader/mayor, deputy commune leader/deputy mayor (there are communes without deputy commune leaders/deputy mayors; however, because we are interested in percentage shares, the data remain comparable), secretary, treasurer, social assistance centre manager. In order to obtain these data we had to analyze the websites or Public Information Bulletins of the particular communes presenting the organizational structure and personnel of their offices. 


\section{The activities of the youth council}

A youth council is a commune body that allows the articulation of the interests of young people in local politics and the development of young people's competencies related to participation in public life. Pursuant to Article $5 \mathrm{~b}$ of the Local Government Act, a commune undertakes activities supporting and promoting the idea of self-government, particularly among young people. Consequently, at the request of interested citizens, commune authorities may give their consent to the establishment of a youth council which has a consultative character. Thus, the content of the Act indicates that commune authorities cannot establish a youth council themselves - this can happen only in response to a bottom-up initiative of inhabitants. This means that the existence of such a council is also a measure of young people's civic activity, and not only a measure of institutional solutions resulting from the will of authorities ${ }^{143}$. But if we assume that communes' duties include supporting and promoting the idea of self-government among the youth, we can deduce from this an obligation to encourage young people to establish such a council. Therefore, we treat the existence of a youth council as a measure of commune authorities' commitment to creating a body strengthening the position of the youth in the local public space. Information concerning youth councils was obtained thanks to a questionnaire sent to the commune offices. Also in the case of this index, we have to face the problem of its "overlapping" with participation as another dimension of the quality of governance. Another problem is the fact that the functioning of a youth council does not prove its real influence - its voice may be ignored, it may be just a façade, or its sessions may be convened sporadically. In this study, we do not undertake to check the factual position of youth councils in local power structures; we only identify whether they exist or not.

\section{The activities of the senior citizens council}

Similarly to the case of youth councils, this index is a measure of equality strengthened thanks to the articulation of the interests of elderly people in a commune's politics. It is based on the assumption that the existence of senior

143 The research conducted in the Małopolskie province by the Stańczyk Foundation in 2013 shows that the establishment of a youth council is a rare event. Among 183 communes, only 16 communes had youth councils. Youth councils had existed earlier in 16 communes, but they had been dissolved in 11 of them because of practically no interest on the part of young people (Niedośpiał 2013). 
citizens councils increases the level of local egalitarianism by preventing discriminatory practices targeted at the elderly. Since the 2013 amendment to the Local Government Act and the introduction of Article 5c, communes have been encouraged to establish senior citizens councils which fulfil consultative, advisory and initiative functions. Pursuant to Article $5 c$, commune councils "on their own initiative or at the request of interested groups, may establish a senior citizens council. The formulation "may establish" indicates that the appointment of such a council by commune authorities is non-obligatory, but because a commune itself may undertake an initiative to establish such a council (unlike in the case of a youth council), the existence of a senior citizens council is an indicator of authorities' involvement in a dialogue with senior citizens. The weakness of this index is its correspondence with the principle of participation and the same problem that applies to youth councils - the existence of a senior citizens council does not make it possible to draw conclusions about its factual influence ${ }^{144}$.

\section{The degree of the poverty risk}

This index is a measure of the social marginalization risk among the inhabitants of a particular commune; the higher the risk of such marginalization, the lower the level of socio-economic equality. The degree of the poverty risk may be determined on the basis of data provided by the Regional Social Policy Centre in Opole, which publishes reports on the risk of poverty in the particular communes of the Opolskie province. Such reports use an indicator describing the risk of poverty. Its value ranges from 0 to $1^{145}$. It seems that one of the major weaknesses of this index is the fact that the level of poverty in a commune depends not only on commune authorities' politics, but is also the resultant of historical and macrostructural conditions. Thus, a commune is assessed on the basis of what it is only partly responsible for.

144 Research on senior citizens councils shows that they are established very rarely. In 2014 only 76 such councils functioned in almost 2500 communes. Research indicates also that their character is activating rather than advisory and consultative and their relations with commune authorities are not based on partnership, pp. 64-65.

145 Such reports are published regularly by the Social Policy Observatory at the Regional Social Policy Centre (ROPS, 2016a). 


\section{Efficiency sub-index}

\section{The commune's own income per 1 inhabitant}

Pursuant to the constitution, territorial self-governing units are entitled to financial independence expressed in their right to own property, other propertyrelated rights, and the right to impose taxes and fees within statutorily determined ranges ${ }^{146}$. Local government units have their own income, i.e. all income that is not general grants or subsidies paid from the national budget. Such income comes from sources located in the territory of a given local government and is transferred to it in whole and without any time restrictions. A local government can exert influence on the sources of such income (Kotlińska 2009: 144$145)^{147}$. Consequently, the amount of a commune's own income can be regarded as a result of its financial policy and, simultaneously, a measure of its financial autonomy (Zawora 2013: 525). Thus, we use the data on the amounts of the communes' own income per 1 inhabitant as published by the Local Data Bank of the Central Statistical Office as a measure of their efficiency. It should be noted that the level of a commune's own income depends on a number of external factors such as a general economic position of the country, the legal system regulating local governments' financial matters, the size of a commune, its infrastructural development, location with respect to major transport routes, or the qualities of its natural environment (Ibidem: 525-526). From the perspective of inter-communal comparisons within the province, of particular importance are the three last factors that can determine the size of a tax base and the amount of inflows independently of the activities of commune authorities in this respect. On the other hand, commune authorities have also at their disposal instruments allowing them to shape the dynamics of social and economic development. If they are to bring about expected results, even advantageous external factors have to be incorporated in an effective local development strategy.

\section{Investment expenditures from the commune budget per 1 inhabitant}

This index, in a sense, complements the previous one because the amount of investment expenditures depends on a commune's own income. Eugeniusz

146 See Articles 165,167, 168 of the Constitution of the Republic of Poland of 2 April 1997.

147 The most important income is income from taxation (including a share in natural and legal person income tax) and fees, income derived from a commune's property, as well as income from fines and penalties (The Act of 13 November 2003). 
Sobczak notes that if a large part of income comes from external sources, a commune finds it more difficult to plan long-term investment projects because of the uncertainty of financing sources (Porycka 2016). Capital expenditures concern technical, transport, social and educational infrastructure. They are an important instrument of building a commune's competitive advantage and thus also conditions for sustainable economic development (Ibidem). Investment expenditures are referred to as active expenditures as they are the effect of local authorities' deliberate intervention in the local socio-economic system (Zygmunt, Mach 2011: 168). Thus, they are a measure of commune authorities' readiness and ability to ensure a long-term growth for the commune. The data concerning the amounts of the communes' investment expenditures per 1 inhabitant come from the relevant report of the Central Statistical Office concerning the Opolskie province.

\section{The percentage of people using social assistance services on a long-term basis in relation to all people receiving social benefits}

Article 7 of the Commune Government Act obliges communes to ensure the provision of social assistance. At the same time the best situation occurs when people receiving social assistance are not permanently dependent on it. The contemporary system of social assistance in Poland, or at least its official philosophy, requires that Social Assistance Centres (SAC) conduct an active social policy consisting in activating, educating and integrating beneficiaries with respect to the main aspects of the socio-economic life of a commune (Łojko 2014: 206-211). New instruments have been introduced, e.g. a social contract which, through an individualized approach to a beneficiary and their social activation, is to help them to overcome difficult socio-economic circumstances. The essence of this tool is an increase in the effectiveness of social support programs and an attempt to limit the range of unconditionally granted social security benefits (ROPS 2014). In the context of a social policy understood in this way, we decided that the ratio of persons receiving social assistance on a long term basis to all social security beneficiaries was a relevant measure of the effectiveness of a commune's activation measures. People receiving social security benefits for long periods of time are defined as those who were registered in the social assistance system for at least 18 months during a period of 36 months. A high percentage of such persons indicate that a commune is not effective in the area of social inclusion as both a body carrying out a social policy through its Social Assistance Centre and a body responsible for the policy of local development. The data come from the report of the Regional Social Policy Centre (ROPS 2016b). Assessing this index, we should 
remember about its weaknesses. The level of permanent reliance on social assistance depends also on factors unique for a particular commune (e.g. the areas of former State Agricultural Enterprises), an economic situation, which only partly depends on commune authorities, and actions undertaken by the other institutions providing social support, e.g. employment services. The Polish system of the so-called active social policy is characterized by a high level of fragmentation consisting in the parallel functioning of a few institution sectors and the lack of cooperation among them. Consequently, there is no integrated and thus, effective, approach to the problem of social exclusion (Rymsza 2014: 168-170). What happens at the level of communes is also the effect of macrosystem dysfunctions.

\section{Current expenditures on public administration per 1 inhabitant}

The proposed index concerns the "weight" of the costs of local bureaucracy and thus, it is regarded as a measure of a commune's thrift and economical management. In this case, we decided to use the data from the ranking prepared by Paweł Swianiewicz and Julita Łukomska for the periodical "Wspólnota". In the all-Poland ranking called "The Frugal Office", they took into consideration current expenditures on public administration with the exception of expenditures on current repairs, which were regarded as too incidental and distorting the value of the index (Swianiewicz, Łukomska 2014). The report shows that in the years 2008-2014 expenditures on administration were rising in rural communes; there was a general tendency towards higher expenditures on administration in smaller local government units. In the smallest rural communes (up to 5000 inhabitants), administration costs more than in large rural communes and the same relationship occurs in the case of small (up to 10,000 inhabitants) and larger towns (Ibidem: 4). Interpreting this index, we should remember that small communes are usually the most expensive. Paweł Swianiewicz emphasizes that what should be taken into consideration is that higher expenditures on administration do not have to mean wastefulness, but rather better and more efficient services for inhabitants or effectiveness in obtaining EU funds. Some of the most expensive local governments also hold high positions in the rankings of the richest ones (Ibidem).

\section{The commune's usage of one of the three quality management systems (CAF, Institutional Development Planning, ISO 9000)}

The possession of a quality management system is a measure of commune authorities' development of a strategic mission with respect to the operational efficiency of the commune office. Local governments have been able to pursue 
such missions since 2008 when opportunities appeared for the acquisition of EU funds for the implementation of quality management systems under the Operational Programme Human Capital 5.2.1 Modernization of management in local government administration. A case study conducted in the commune of Dzierżoniów showed that the implementation of a quality management system had a positive influence on the efficiency of the planning, execution and accounting of projects financed by the EU (Wójtowicz, Paciorek 2012: 9). Thus a quality management system is an important indicator of a comprehensive approach to the problem of efficiency, although, according to data from 2009, it is used relatively rarely. Back in 2009 only $18 \%$ of rural communes, $19 \%$ of rural-urban communes, and $38 \%$ of urban communes declared that they used quality management instruments (Żabiński 2012: 58). This is also confirmed by the results of our survey in which we asked about the use of one of the three most popular quality management models in public administration, i.e. CAF (The Common Assessment Framework), PRI (the method of Planned Institutional Development), and ISO 9000. Only 3 out of the 60 surveyed communes declared that they used one of the three systems ${ }^{148}$. Many researches specializing in this subject indicate that such systems are often introduced by communes because of greater chances of success in applying for financing from external sources. Thus, a quality management system is not always the effect of strategic thinking about how a commune should be managed, but rather a marketing instrument (Bober 2008: 136). Nevertheless, we are of the opinion that irrespective of motivation for its implementation, its existence and functioning is a positive phenomenon promoting efficiency improvement.

\section{Accountability sub-index}

\section{The existence of a local media organization that is not controlled by the commune authorities}

A certain report on websites maintained by towns and villages with fewer than 20,000 inhabitants emphasizes that "in practice, any website dedicated to local

148 In the survey, in order to verify the validity of the functioning of quality management systems we asked also for the date of its latest certification or self-assessment. On this basis, we concluded that a system is being used if the latest process of its certification or self-assessment took place in the years 2016-2017. Consequently, we did not acknowledge the functioning of a quality management system in one commune which declared that it had carried out the self-assessment process in 2015. 
issues sooner or later deals with politics" (Danielewicz, Mazurek 2012: 43). If a person running a website writes, for example, about a street lamp that has been out of order for a few days, this automatically provokes readers to start discussions, ask questions about neglect on the part of the authorities, and make comparisons with other communes. The authors point out that such websites become public opinion catalysts, a counterbalance for authorities, and a controlling institution. The conducted research showed that authorities react differently to the existence of such websites - from open aggression and hostility, through distrust and creation of difficulties in access to public information, to the establishment of cooperation (Ibidem). Even if local media do not have a clearly guarding character and focus more on describing the life of a commune, including the actions of its authorities, we recognized them as a forum where local authorities can be brought to account. The conditions are that such media cannot be established or financed by a commune's executive body, they have to exist at the time of a survey, and they provide information on the actions of authorities, inclusive of critical information. We used quite broad qualification criteria allowing us to acknowledge the existence of such media. Thus, such media included commune periodicals, websites, local television stations or blogs maintained by councillors. Such media had to be rooted in a given commune and frequently refer to its life and events. We searched for information on the existence of local media in each commune on the internet, using the following set of key words: local media in the commune of $\mathrm{x}$; information website of the commune of $\mathrm{x}$; the voice of the commune of $\mathrm{x}$; the news of the commune of $\mathrm{x}$. We are aware of the problems that local media have to cope with such as financial impermanence and dependence on local businesspeople or local government institutions as advertisers (Markowski et al 2014: 73) - obviously, these factors influence their ability to fulfil the function of accountability. But, constructing this index, we do not take into consideration such a complex and multidimensional picture of local media.

\section{The publication of internal inspection reports in the Public Information Bulletin for the years 2015-2016}

This index is based on the assumption that internal inspection reports and what happens to them allow their readers to draw conclusions on a given commune's readiness to account for its own irregularities. One of the communes of the Opolskie province was a source of inspiration for its development. A local nongovernmental organization called Foundation for Future and Development published an article entitled "The Mayor in the Spotlight" (2014) in which it referred critically to a post-inspection report presented by the Regional 
Accounting Chamber. The report allegedly indicated that the mayor had not followed recommendations included in a previous post-inspection report. This case illustrates the role of the availability of documents drawn up by external controlling institutions and the possibility of using such documents by local activists for the purpose of the civil supervision over commune authorities. In this case, the aforementioned non-governmental organization had to obtain the document and publish it because the Public Information Bulletin of the commune did not provide information on external audits or inspections. This constituted a basis for the assumption that publishing such documents (particularly those indicating some irregularities) by entities that are subjects of inspections proves their readiness to undergo public assessment and helps local communities to monitor the actions of local authorities because it highlights concrete irregularities. If a commune publishes reports on external inspections, it shows its identification with the idea of accountability (it accounts for its irregularities) and increases the probability of using such data by inhabitants, i.e. provokes them, as it were, to demand that authorities account for their actions. Post-inspection reports inform a local community whether authorities act honestly. Analyzing this index, we checked whether the particular commune authorities had published any post-inspection document in their Public Information Bulletins for the years 2015-2016. If there was at least one such document in the Bulletin, a commune scored one point; if there was no such documentation, no point was granted. It is highly improbable that no external inspection was carried out in any commune during that period ${ }^{149}$. Mark Bovens indicated that information publication itself does not constitute accountability; it is its preliminary condition because what is necessary is a committed journalist, a local interest group, or a local activist that can use such information to ask authorities difficult questions (Bovens 2006: 13). Therefore, it should be remembered that the proposed index is rather a measure of a commune's organizational culture that creates better or worse conditions for local forums to exercise supervision over decision makers.

149 If we adopt the commune of Chrząstowice which publishes post-inspection reports in a dedicated tab on its website as a point of reference, there were ten such inspections during the years 2015-2016. The commune undergoes inspections carried out by not only the Regional Accounting Chamber and the Provincial Office but also such institutions as the State Archives in Opole, the Treasury Control Office in Opole, the State Labour Inspection, and the Marshal Office. 


\section{The number of candidates for the position of commune leader/mayor in the 2014 local government elections}

We are of the opinion that the absence of political competitors combined with the model of a strong mayor, which frequently occurs in the Polish local government system (Swianiewicz, Klimska 2003: 21-24), may facilitate the abuse of power. As Susan Rose-Ackerman writes, "a strongly competitive political environment raises the stakes and decreases the probability of corruption; consequently, a political system based on competition may reduce corruption" (Rose-Ackerman 2001: 241). Thus, political competition may be regarded as an instrument of accountability making it possible to reduce a sense of having a monopoly on executive power in a commune. Research on the Polish local government system shows that the phenomenon of low political competitiveness concerns first of all small communes and the largest cities, where we can witness the largest share of mayors and city presidents holding their offices for many terms. It is emphasized simultaneously that a lack of a political competitor does not have to indicate the existence of pathological relations in local authorities, but it may be the result of the effective leadership of local authorities and a lack of competent competitors among small local elites (Gendźwiłł, Swianiewicz 2017). Nevertheless, being aware the possibility of the occurrence of such cases, we adopted the assumption that a small number of candidates running for mayor is a negative phenomenon from the point of view of accountability. A candidate without a rival or with a small number of rivals has an attitude towards voters, the commune's matters, and their own place in the local system of power different from that of a person who has to take into consideration the risk of competition and arguments presented by competitors. In such circumstances, many local issues that could be raised by rivals may never appear during the course of an election campaign. Such a candidate is not regularly confronted with a competitive vision of the commune's development and their rivals' critical comments. A lack or a small number of candidates indicate also the strength and mobilization of local groups with respect to their interest in the matters of their commune as well as their readiness to assume responsibility for its governance. Thus, subsequent candidates constitute unique forums where different interest and pressure groups of the local political system are able to present their agendas. The source of data for this index is the National Electoral Commission. 


\section{The publication of the councillors' and the commune leader's property statements in the Public Information Bulletin for the year 2016 before 2 June 2017}

Pursuant to Article $24 \mathrm{~h}$ of the Local Government Act, by 30 April every year local government officials and politicians are obliged to submit property statements valid as at 31 December of the previous year. The submission of property statements is one of the basic instruments allowing people holding public offices to account for their property. It allows the performance of controlling functions by such supervisory institutions as tax offices or the Central Anti-corruption Bureau, as well as social supervision exercised by the mass media, local communities, or non-governmental organizations. A condition for the effective exercise of social supervision is an easy access to property statements based on their publication in Public Information Bulletins. Within the scope of the assessment of accountability, we decided to check whether one month after the statutory deadline for the submission of property statements by councillors and mayors they had already been published in Public Information Bulletins. The adopted deadline results from statutory regulations (Article 24h, Paragraph 5) according to which if a statement is not submitted by 30 April, the entity responsible for the reception of statements is obliged to call the person to submit a statement within 14 days from the date of determining a lack of a statement. Assuming that a lack of a statement should be determined after the so-called long May holiday weekend and taking into consideration additional 28 days for the performance of the procedure described above, on 2 June we checked whether the Public Information Bulletins of the surveyed commune offices had published the property statements of their councillors and mayors. Interpreting this accountability index, we should remember that it does not indicate whether councillors and mayors have submitted their property statements. It is possible that they have been submitted by the statutory deadline, but have not been published yet because the Act does not specify when submitted statements should be published in Public Information Bulletins. The index does not say anything about the quality of the content of property statements. According to the authors, in a sociological sense, the index indicates the degree of local authorities' determination to reveal information concerning the property of their members publicly and effectively.

\section{The percentage of the councillors with higher education during the term of office 2014-2018}

International comparative research on relationships between the level of education and the quality of governance shows that the higher the level of education, 
the better the quality of governance. This results from the fact that educated people tend to file complaints about officials' abuses of power or incompetence and to report crimes. According to researchers, such persons are aware of the available instruments used to report irregularities and are less afraid of the negative consequences of reporting irregularities ${ }^{150}$. Thus, education is cultural capital favoring accountability. Unfortunately, data concerning the percentage of people with higher education at the commune level are not available ${ }^{151}$. Nevertheless, the Local Data Bank of the Central Statistical Office provides data on the level of education of councillors. In the commune accountability regime, the council constitutes a forum performing the controlling function with respect to the executive body. At the same time it is emphasized that one of the problems facing the Polish local government system is a lack of balance in the governance of a commune consisting in the weakness of a commune council in relations with a strong mayor. Councillor has limited possibilities of exercising supervision over executive bodies, while executive bodies receive support from the whole administrative apparatus of a commune (Sześciło 2016). Therefore, it is recommended that, among other things, councillors be provided with experts' support (Ibidem), and the amendments to the Local Government Act introduced in January 2018 are to strengthen their position vis-à-vis executive bodies (Sześciło 2018). In our opinion, the level of councillors' education may be one of the factors determining their substantive preparation for the monitoring and controlling of executive bodies. In this context, higher education is regarded as cultural capital that strengthens the councillors' position in relations with executive bodies. It should be remembered that the proposed index is a measure of resources favoring accountability, and not the application of available accountability instruments.

\section{Openness sub-index}

\section{The local government authorities' timely response to the questionnaire}

The use of this index was inspired by one of the institutional efficiency indexes applied by Robert Putnam in his famous research on Italian regions. In this research,

150 Such conclusions are based on survey data collected in 97 countries within the scope of the World Justice Project and in 78 countries within the scope of the International Crime Victims Survey (Botero, Ponce, Shleifer 2013: 962-967).

151 The latest such data concerning the Opolskie province come from the 2002 census (Rauziński, Szczygielski 2013: 91-92). 
acting the roles of citizens, Putnam's assistants sent various offices in every region requests for information concerning three concrete matters. On the basis of how quickly information was provided and its quality, the researchers assessed officials' willingness to provide citizens with efficient services (Putnam 1995: 111-112). We decided to use our questionnaire not only as a research method but also as a measure of officials' openness to the social environment. But we did not pretend to be ordinary citizens, and introduced ourselves as researchers of local democracy (see the questionnaire in Annex 3), concluding that a timely response to the questionnaire could be one of the indicators of willingness to share information with others. On 7 July 2017 we sent the internet questionnaire together with a request to fill it in by 21 July 2017 to 60 commune offices. Thus, the deadline for returning the questionnaire corresponded to the period of 14 days provided for in the Public Information Access Act of 6 September 2001, but our cover letter did not contain any references to this Act. During that period we sent another email to those commune offices that had not acknowledged the receipt of the previous one and one day before the expiry of the deadline - one more email with a reminder of the deadline for returning the filled in questionnaire. Consequently, before 21 July we had received responses from 42 communes $^{152}$.

\section{Easy access to and availability of a valid annual programme of cooperation with non-governmental organizations}

Pursuant to Article 5a of the Public Benefit Activities and Voluntary Service Act, a commune is obliged to adopt an annual (or long-term) programme of cooperation with non-governmental organizations. Before such a programme is adopted, it needs to be consulted with non-governmental organizations. A commune is obliged to publish a draft programme, to announce related consultations, and to publish a programme execution report. However, there is no obligation to publish such an annual cooperation programme with the exception of its publication in the register of resolutions adopted by a commune council as an attachment to a resolution. The ease of finding such a programme in a Public Information Bulletin or on a commune's website is a measure of a commune's organizational culture rather than its fulfilment of procedural requirements. We adopted the

152 Another 3 communes returned the questionnaire after the deadline. On 26 July the remaining 15 communes were sent an email with an official request to provide public information in the form of answers to the questions included in the questionnaire. Ten of them answered our questions. 
assumption that a commune open to cooperation with non-governmental organizations as institutionalized representatives of a civil society provided the most important information concerning the rules of such cooperation. We followed the following data search procedure: a) write the phrase "annual programme of cooperation with non-governmental organizations in the commune of $x$ " in the Google search engine - if the first page of results showed a link to a document containing a cooperation programme (not a draft) adopted and signed by the commune council, the condition was regarded as fulfilled; b) if the Google search engine did not return any results, we analyzed the commune's website and Public Information Bulletin, looking for a cooperation programme in such tabs as "non-governmental organizations", "cooperation with non-governmental organizations", "public benefit", "strategic documents and programmes". We ignored lists of resolutions adopted by commune councils, assuming that even if they contained an annual cooperation programme (which had not been found earlier by the Google search engine), it was too difficult to locate; c) if both methods failed, the condition was regarded as unfulfilled.

\section{The number of non-governmental organizations which have submitted comments on the programme of cooperation with non-governmental organizations}

As it has already been mentioned in the case of the previous index, the programs of cooperation with non-governmental organizations should be consulted with such organizations. However, the question arises about the factual scope of such consultations, i.e. the number of non-governmental organizations participating in such consultations. We assumed that the number of non-governmental organizations that presented their opinions under the consultative procedure was, on the one hand, a measure of the circulation of information on consultations and, on the other hand, a reflection of the activity of local non-governmental groups. Thus, an assessment formulated on the basis of this criterion concerns the activities of both commune authorities and non-governmental organizations themselves related to their joint work on the most important document determining relations between them. The source of data for this index was the CAWI questionnaire.

\section{The passing of a resolution determining the rules and procedures of social consultations}

Social consultations belong to the most fundamental instruments of a dialogue between authorities and society and the latter's inclusion in the process of exercising power. The Local Government Act obliges every commune to conduct 
consultations in the cases provided for in the Act (e.g. obligatory consultations on annual programs of cooperation with non-governmental organizations) and let's commune exercise discretion as to the organization of consultations about other matters "important for the commune". Pursuant to Article 5a of the Act, the rules and procedures of such consultations are determined in a relevant resolution of a commune council. Nevertheless, it should be emphasized that the Act does not specify whether it is necessary to adopt a document setting forth the general rules of conducting consultations or to adopt a separate resolution for every consultation. Therefore, commune authorities use various solutions and do not always adopt one general resolution regulating the matter of consultations ${ }^{153}$. For example, research conducted in the Podlaskie province showed that such resolutions had been passed by $60 \%$ of the communes (Maszkowska, Wenclik 2014). We assumed that the existence of such a resolution was an indicator of authorities' openness to the idea of social consultations. It should be noted that the existence of such a resolution constitutes the fulfilment of only minimum procedural requirements related to social consultations, i.e. it does not determine the quality of consultations. Thus, our index is a considerable simplification and it should be kept in mind that a multidimensional analysis of consultations as a measure of openness would require answers to a number of questions about the factual use of this institution at the local level. The source of data for this index was the CAWI questionnaire.

\section{The publication of commune council session minutes for the year 2017 in the Public Information Bulletin}

The last openness index is a measure of the transparency of a commune's resolution-making body. Article 11b of the Local Government Act states that the activities of commune bodies are open to supervision, and within the scope of this openness, citizens have the right, among others, to access documentation resulting from the performance of public tasks, including the minutes of meetings held by commune bodies. Therefore, we decided to check whether the communes published successive council meeting minutes in their Public Information Bulletins. On 15 August 2017 we reviewed the Public Information Bulletins of the individual communes with respect to the availability of council

153 Sometimes this matter is regulated in a commune statute or a separate resolution is adopted for individual consultations (Starczewski 2009). 
meeting minutes for the year 2017. A commune council should hold a meeting at least once a quarter. Consequently, we concluded that by August at least two council meetings should have been held (in practice, council meetings are convened on average once a month). Thus, if at least two sets of minutes for 2017 were available, we considered that a commune had fulfilled the criterion of openness in this respect. 



\section{Annex 3}

\section{The CAWI questionnaire (sent on 7 July 2017)}

\section{Dear Madam/Sir}

The Institute of Political Sciences of the Opole University is conducting research on the functioning of commune/town offices in the Opolskie province in the framework of the project funded by the National Science Centre. The objectives of the research include, among others, a diagnosis of the use of solutions facilitating the strengthening of local democracy. In connection with the aforementioned research, we would like to ask you to provide answers to the following questions. The questionnaire consists of 20 questions.

1. Can you provide the name of the commune that you represent?

2. Does your commune have an active youth council?

a) yes

b) no (if the answer "no" is chosen, please move to question 5)

3. If your commune has a youth council, when was it established (this question concerns the year in which the council was established, and not the year of the approval of its latest term)?

4. Can you provide the exact date of the latest session of the youth council?

5. Does your commune have an active senior citizens council?

a) yes

b) no (if the answer "no" is chosen, please move to question 7)

6. If your commune has a senior citizens council, when was it established (this question concerns the year in which the council was established, and not the year of the approval of its latest term)?

7. Can you provide the exact date of the latest session of the senior citizens council?

8. Can you provide the number of interpellations submitted by the councillors, irrespective of whether they were written or oral? 
9. Can you provide the number of questions asked by the councillors, irrespective of whether they were written or oral?

10. Did the commune/town office receive any complaints in the year 2016 (this concerns complaints within the meaning of the Code of Administrative Procedure)?
a) yes
b) no (if the answer "no" is chosen, please move to question 12)

11. If so, can you specify how many complaints the commune/town office received in 2016 ?

12. Did the commune/town office receive any proposals in the year 2016 (this concerns proposals within the meaning of the Code of Administrative Procedure)?
a) yes
b) no (if the answer "no" is chosen, please move to question 13)

13. If so, can you specify how many proposals the commune/town office received in 2016?

14. Has the commune adopted a resolution specifying the rules of conducting social consultations?
a) yes
b) no (if the answer "no" is chosen, please move to question 16)

15. If so, can you provide the exact date of adopting a resolution specifying the rules of conducting social consultations in the commune?

16. How many non-governmental organizations submitted, under the consultative procedure, their comments/opinions concerning the annual programme of cooperation with non-governmental organizations for the year 2017?

17. Did the commune prepare a report on consultations about the annual programme of cooperation with non-governmental organizations for the year 2017?

18. How was the report on the conducted consultations about the annual programme of cooperation with non-governmental organizations for the year 2017 publicized?
a) It was published on the office's website/in the Public Information Bulletin
b) It was sent by regular/electronic mail to the interested parties
c) It was made available for inspection in the commune/town office 
d) no measures were taken to publicize the report

d) others

19. Does the commune use one of the quality management systems mentioned below?
a) ISO 9000
b) PRI (the method of Planned Institutional Development)
c) CAF (The Common Assessment Framework)
d) the commune does not use any of the aforementioned quality management system

20. If the commune uses one of the above systems, in which year was the latest self-assessment or certification procedure conducted? 



\section{List of figures}

Fig. 1: Level of trust towards local authorities, national government and generalized trust in Poland 2002-2018.

Fig. 2: Election turnout to the local and parliamentary elections in Poland 1993-2019*.

Fig. 3: The number of councillors representing the German minority in the commune councils of the Opolskie province during the term of office 2014-2018.

Fig. 4: The governance quality index in the communes of the Opolskie province.

Fig. 5: The relationship between ethnic diversity and the quality of governance at the communal level.

Fig. 6: The relationship between the number of inhabitants in a commune and the quality of governance at the communal level.

Fig. 7: The relationship between the urbanization index and the quality of governance at the communal level.

Fig. 8: The relationship between ethnic diversity and the sub-index of participation in all communes covered by the research.

Fig. 9: The relationship between ethnic diversity and the sub-index of participation in the rural communes. 



\section{List of maps}

Map 1: Minorities in Poland. Source: the authors' own work......................... 15

Map 2: Ethnic diversity of Opolskie province. Source: the authors

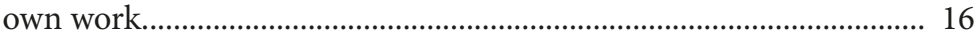

Map 3: Border changes in Silesia. Source: the authors' own work. ................ 72 



\section{List of tables}

Tab. 1: The cultural and ethnic diversity of the Opolskie province in the years 1948-1993: the number of inhabitants, nomenclature, data sources

Tab. 2: Ethnic fractionalization in the communes of the Opolskie province

Tab. 3: Selected sources of the principles of good governance ...................... 50

Tab. 4: Selected tools used to measure the quality of governance at the local level

Tab. 5: The Local Level Governance Quality Index (25 points)

Tab. 6: The Opolskie province against a background of the other Polish provinces in terms of the basic geographic and demographic data

Tab. 7: Selected life quality indexes for the Opolskie province 67

Tab. 8: The position of the Opolskie province in comparison to the other provinces with respect to selected governance quality indexes (data for 2016; in \%)

Tab. 9: The scores of the Polish regions achieved in the European Governance Quality Index in the successive editions of the research (the scale from 0 to 100 , where 0 indicates the lowest quality, and 100 - the highest quality)

Tab. 10: Basic information concerning the communes covered by the research

Tab. 11: The values of the governance quality index and the subindexes in the communes participating in the research 86

Tab. 12: The correlations between the selected variables $(n=60)$ 90

Tab. 13: Partial correlations between EFI and the governance quality index adjusted for the impact of the selected variables

Tab. 14: Correlations between EFI and the governance quality index and its sub-indexes in the selected categories of the communes

Tab. 15: Selected information on the communes selected for the qualitative analysis

Tab. 16: The composition of the Kolonowskie commune council during the terms 2002-2018

Tab. 17: The structure of the council of the commune of Walce during the past four terms of office in terms of the number of seats held by the particular groupings 
Tab. 18: The structure of the Paczków town council during the four terms of office in terms of the number of seats held by particular groupings, the number of groupings, and the number of councillors affiliated with political parties

Tab. 19: Financial support provided to non-governmental organizations and the number of organizations that received such support on the basis of the reports on the execution of annual programs of cooperation with non-governmental organizations in the Paczków commune

Tab. 20: The citizens budget of the Paczków commune - the number of submitted project proposals and the number of participating voters

Tab. 21: The structure of the council of the commune of Domaszowice during the past four terms of office in terms of the number of seats held by the particular groupings 


\section{List of interviews}

Interview 1: Member of local action group, Kolonowskie, 25 July 2018.

Interview 2: Local entrepreneur, Kolonowskie, 2 September 2018.

Interview 3: Representative of local self-government, Kolonowskie, 6 June 2019.

Interview 4: Representative of local self-government, Walce, 23 May 2019.

Interview 5: Former employee of Opolskie Voivodship Office, responsible for national minorities issues, 2 September 2019.

Interview 6: Local journalist, Paczków, 25 July 2018.

Interview 7: Representative of local self-government, Paczków, 23 July 2018.

Interview 8: Member of city council, Paczków, 25 July 2018.

Interview 9: Member of local NGO, Paczków, 20 July 2018.

Interview 10: Member of senior citizens council, Paczków, 18 July 2018.

Interview 11: Employee of communal office, Domaszowice, 15 June 2018.

Interview 12: Member of commune council, Domaszowice, 11 June 2018.

Interview 13: Representative of local self-government, Domaszowice, 15 June 2018.

Interview 14: Head of a village, Domaszowice, 7 June 2018.

Interview 15: Local entrepreneur, Domaszowice, 7 June 2018.

Interview 16: Commune' inhabitant, Domaszowice, 6 June 2018. 



\section{Literature}

ads1 (2016). Urzędowa gazeta do każdego domu. Za darmo, Paczków24.pl, 7.02: http://paczkow24.pl/urzedowa-gazeta-do-kazdego-domu-za-darmo/

Alesina, A., Devleeschauwer, A., Easterly, W., Kurlat, S., \& Wacziarg, R. (2003). Fractionalization. Journal of Economic growth, 8(2), pp. 155-194.

Anderson, B. (1997). Wspólnoty wyobrażone: rozważania o źródłach $i$ rozprzestrzenianiu się nacjonalizmu, Kraków: Znak.

Antoszewski, A. (2014). Lokalne systemy polityczne a dobre rządzenie. In: Dobre rzadzenie w gminach małych: empiryczny wymiar nowego paradygmatu rozwoju, Vol. 1, eds. Kobielska K., Lisowska A., Bydgoszcz: Oficyna Wydawnicza Edward Mitek, pp. 34-51.

Baland, J. M., Bardhan, P., Das, S., Mookherjee, D., \& Sarkar, R. (2007). Inequality, collective action and the environment: Evidence from firewood collection in Nepal. Inequality, cooperation and environmental sustainability, 246-274.

Barczyk, S. (2010). Przedsiębiorczy samorząd lokalny i jego instytucje. Katowice: Wydawnictwo Uniwersytetu Ekonomicznego w Katowicach.

Bartek, R. (2015). Rola mniejszości niemieckiej w regionie opolskim. Pogranicze. Polish Borderlands Studies, 3(2), pp. 205-211. https://doi. org/10.25167/ppbs491.

Bartnicki, S. (2015). Wpływ liczby kadencji nieprzerwanego piastowania lokalnej władzy wykonawczej wyłanianej w wyborach bezpośrednich na wybrane gminy, Zeszyty Naukowe Uniwersytetu Szczecińskiego, Acta Politica, 33 , pp. 58-75.

Barwiński, M. (2006). Liczebność i rozmieszczenie mniejszości narodowych i etnicznych w Polsce w 2002 roku a wcześniejsze szacunki, In: M. Bieńkowska-Ptasznik, K. Krzysztofek, A. Sadowski (eds.), Obywatelstwo i tożsamość $w$ społeczeństwach zróżnicowanych. Białystok: Wydawnictwo Uniwersytetu w Białymstoku.

Barwiński, M. (2014). Struktura narodowościowa Polski w świetle wyników spisu powszechnego z 2011 roku. Przegląd Geograficzny, 86(2), pp. 217-241.

Barwiński, M. (2016). Mniejszości narodowe i etniczne w polskiej przestrzeni publicznej. Łódź: Wydawnictwo Uniwersytetu Łódzkiego.

Barwiński, M. (2017). Borderland of Nations, Religions and Cultures - The Case of Podlasie. European Spatial Research and Policy, 24(2), pp. 111-125. 
Berlińska, D. (1998). Stosunki etniczne na Śląsku Opolskim. Śląsk Opolski, 29, pp. 14-23.

Berlińska, D. (1999). Mniejszość niemiecka na Ślasku Opolskim w poszukiwaniu tożsamości. Opole: Stowarzyszenie Instytut Śląski i PIN-Instytut Śląski w Opolu.

Berlińska, D. (2004). Tożsamość i identyfikacje narodowe Ślązaków po 1989 r. Ślask Opolski, 1(50), pp. 9-24.

Berlińska, D., \& Nijakowski, N. (2001). Lobbing na rzecz polskich regionów w Brukseli. Opole: Stowarzyszenie Instytut Śląski.

'Bez radnego' (2015). Paczków bez radnego. Nowiny Nyskie, 6, p. 12.

Bialasiewicz, L. (2002). Upper Silesia: Rebirth of a Regional Identity in Poland. Regional \& Federal Studies, 12(2), pp. 111-132.

Białek, E. (1983). Paczków. Rozwój demograficzny i gospodarczy miasta w PRL (master thesis). Sosnowiec: Zakład Geografii Ekonomicznej Uniwersytetu Śląskiego.

Bober, J. (2008). Metoda rozwoju instytucjonalnego jako narzędzie doskonalenia administracji publicznej na przykładzie strategii rozwoju samorządów terytorialnych. Zarządzanie Publiczne, 3(1), pp. 125-141.

Borys, T. (2014). Koncepcja dobrego rządzenia - istota, cechy swoiste i pomiar. In: Dobre rządzenie w gminach małych: empiryczny wymiar nowego paradygmatu rozwoju, Vol. 1, eds. K. Kobielska, A. Lisowska. Bydgoszcz: Oficyna Wydawnicza Edward Mitek, pp. 52-70.

Botero, J., Ponce, A., \& Shleifer, A. (2013). Education, Complaints, and Accountability. Journal of Law and Economics, 56(4), pp. 959-996.

Bovens, M. (2006). Analysing and Assesing Public Accountability, A Conceptual Framework. European Governance Papers (EUROGOV), C-06-01.

Chakravarty, S. R., \& Maharaj, B. (2011). Measuring ethnic polarization. Social Choice and Welfare, 37(3), pp. 431-452.

Charron, N., Lapuente, V., \& Dijkstra, L. (2012). Regional Governance Matters: A Study on Regional Variation in Quality of Government within the EU. Regional Studies, 48(1), pp. 68-90.

Charron, N., Lewis, D., \& Victor, L. The QoG EQI Data - Country Level (2010 \& 2013 \& 2017), Quality of Government Institute, University of Gotheburg, https://qog.pol.gu.se/data/datadownloads/qog-eqi-data (Accessed 17 April 2018).

Cimała, B., Senft, S. (1994). Ludność rodzima na Śląsku Opolskim w polityce władz wojewódzkich w latach 1950-1956. Studia Śląskie, LIII, pp. 89-120. 
Collier, P.(2000). Ethnicity, politics and economic performance. Economics \& Politics, 12(3), pp. 225-245.

Collier, P. (2001). Implications of ethnic diversity. Economic Policy, 16(32), pp. 127-166.

Collier, P. (2007). The Bottom Billion: Why the Poorest Countries are Failing and What Can Be Done About It. Oxford: Oxford University Press.

'Constitution' (1997). Constitution of the Republic of Poland, founded on 2 April 1997.

Cybula, A., Majcherkiewicz, T.(2005). Wielokulturowość regionu środkowoeuropejskiego a narody i państwa narodowe. Przykład Górnego Śląska. Sprawy Narodowościowe, vol. 26, pp. 135-156.

Cymbrowski, B. (2006). Regionalne środowiska społeczne jako czynnik rozwoju. Dziedzictwo przeszłości, stan obecny a przyszłość województw opolskiego. In: M. Szczepański, A. Śliz (eds.). (2006). Kapitały: ludzie i instytucje. Studia i szkice socjologiczne, Tychy-Opole: Wyższa Szkoła Zarządzania i Nauk Społecznych w Tychach.

Czapiński, J. (2015). Stan społeczeństwa obywatelskiego. Diagnoza Społeczna 2015, Warunki i Jakość Życia Polaków - Raport. Contemporary Economics, 2015 9/4, pp. 332-372. DOI:10.5709/ce.1897-9254.191.

Czapiński, J., Panek, T. (eds.). (2015). Diagnoza społeczna 2015. Warunki i jakość życia Polaków. Warszawa: Rada Monitoringu Społecznego.

Czepil, B. (2014). Korupcja a rozwój. Analiza funkcjonalnych aspektów korupcji. Prakseologia, (155), pp. 295-324.

Czepil, B. (2015). Kulturowe i instytucjonalne bariery korupcji w państwach nordyckich. Opole: Wydawnictwo Uniwersytetu Opolskiego.

Czepil, B. (2016). The 'Fight Against Corruption' as a Never-Ending and SelfLegitimizing Process. Studia Socjologiczne, 223(4), pp. 201-228.

Dąbrowski, K. (1996)., Paczków - szkice z dziejów miasta, Opole: Instytut Śląski

Dahl, R. A. (1995)., Demokracja i jej krytycy, Kraków: Społeczny Instytut Wydawniczy Znak.

Danielewicz, M., \& Mazurek, P. (2012). Technospołecznicy. Rozkwit mediów lokalnych, Centrum Cyfrowe: Polska, https://nck.pl/badania/raporty/ technospolecznicy-rozkwit-mediow-lokalnych (Accessed 19 May 2019).

De Tocqueville, A. (2005). O demokracji w Ameryce. Warszawa: Fundacja Aletheia.

'Delegacja'(2015). Delegacja z Uzes z wizytą w Paczkowie. Retrieved 13 January 2020 from http://paczkow24.pl/delegacja-z-uzes-z-wizyta-w-paczkowie/ .

Dimitrow, R. (2016). Jak Stradunia zapracowała na tytuł najpiękniejszej opolskiej wsi, Nowa Trybuna Opolska, 05.09.16: https://nto.pl/ 
jak-stradunia-zapracowala-na-tytul-najpiekniejszej-opolskiej-wsi-galeria/ ar/12386068.

Dimitrow, R. (2019). Policzyli Ukraińców po tym, co mają w smartfonach. Accessed 3 April 2019 at: https://nto.pl/policzyli-ukraincow-po-tym-comaja-w-smartfonach/ar/13953229 (Accessed 3 April 2019).

Dinesen, P. T., Sønderskov, K. M. (2018). Ethnic diversity and social trust: A critical review of the literature and suggestions for a research agenda. The Oxford handbook on social and political trust. Oxford: Oxford University Press.

Dobras, M. (2016). Health literacy jako element polskiego systemu opieki profilaktycznej nad pracownikami, "Medycyna Pracy," vol. 67, pp. 681-689, Ddoi: .org/10.13075/mp.5893.00410.

Dolińska, K. (2016). O wielokulturowości pożądanej i niepożądanej w polskim kontekście - wymiar narodowy i lokalny. In: A. Adamczyk, A. Sakson, C. Trosiak (eds.), Polityczne i społeczne aspekty wielokulturowości. Migracje i mniejszości. Poznań: Wydawnictwo Naukowe WNPiD UAM, pp. 425-442.

Drozd-Piasecka, M. (1988). Warunki gospodarczo-społeczne a stosunek mieszkańców wsi południowo-wschodniego Mazowsza do ziemi. Etnografia Polska, 32(1), pp. 263-288.

'Dużo' (2017). Paczków. Dużo wiem o swoim mieście. Nowiny Nyskie, 18, p. 16.

'Dwa' (2015). Dwa miesiące Rolki, Nowiny Nyskie, 7, p. 13.

'Dyrektor' (2014). Dyrektor wbrew prawu, Tygodnik Krapkowicki', 23.04, nr 16.

Działek, J. (2011). Kapitał społeczny-ujęcia teoretyczne i praktyka badawcza. Studia Regionalne i Lokalne, 3(45), pp. 100-118.

Easterly, W., Levine, R. (1997). Africa's growth tragedy: policies and ethnic divisions. The quarterly journal of economics, 112(4), pp. 1203-1250.

Esteban, J. M., \& Ray, D. (1994). On the Measurement of Polarization. Econometrica, 62, pp. :819-851.

'Expose' (2014). Expose nowego burmistrza. http://paczkow24.pl/exposenowego-burmistrza/ (Accessed 19 September 2018).

Fearon, J. D. (2003). Ethnic and Cultural Ddiversity by Country. Journal of Economic growth, 8(2), pp. 195-222.

Fikus, S. (2015)., Mniejszość niemiecka: złote czy kukułcze jajo? Tygodnik Krakpowicki, 36, 08.09.2015.

Flis, J. (2018). Wybory samorządowe - wzory zaangażowania. Downloaded from: http://www.batory.org.pl/dla_mediow/kto_i_jak_zaglosuje_w_ wyborach_samorzadowych_1 (Accessed 30 October 2018). 
Fukuyma, F. (2013). What is governance? Center for Global Development, Working Paper 314, pp. 01, www.cgdev.org/files/1426906_file_Fukuyama_ What_Is_Governance.pdf (Accessed 29 June 2017).

Ganowicz, E., \& Opioła, W. (2017). Specyfika partyjnej rywalizacji politycznej w wyborach do samorządu terytorialnego w roku 2014 na przykładzie województwa opolskiego. Przegląd Politologiczny, 2, pp. 137-155. DOI: 10.14746/pp.2017.22.2.9.

Gdula M., Dębska K., \& Trepka K. (2017). Dobra zmiana w Miastku. Neoautorytaryzm $w$ polskiej polityce z perspektywy małego miasta, Instytut Studiów Zaawansowanych, Warszawa: http://krytykapolityczna.pl/file/ sites/4/2017/10/Dobra-zmiana-w-Miastku.pdf (Accessed 5 February 2018).

Geisler, R. (2009). Górnośląski regionalizm jako praktyka dyskursywna. Studia Socjologiczne, 4, pp. 63-83.

Geisler, R. (2015). Fenomen śląskiej etniczności jako postkolonialna emancypacja. Pogranicze. Polish Borderlands Studies, 3(2), pp. 105-116.

Gelner, E. (2009). Narody i nacjonalizm. Warszawa: Difin.

Gendźwiłł, A. (2011). O partyjności i bezpartyjności demokracji lokalnej, Studia Polityczne, 26, pp. 7-27.

Gendźwiłł, A., \& Swianiewicz, P. (2017). Czy potrzebujemy limitu kadencji w samorzadzie?, Warszawa: Fundacja Batorego, http://www.batory.org.pl/ upload/files/Programy\%20operacyjne/Masz\%20Glos/Czy-potrzebujemylimitu-kadencji-w-samorzadzie.pdf (Accessed 21 November 2018).

Gendźwiłł, A., \& Żerkowska-Balas, M. (2018). Polacy o samorządach. Opinia publiczna u progu samorzadowej kampanii wyborczej. Warszawa: Fundacja im. Stefana Batorego.

Gendźwiłł, A., \& Żółtak, T. (2012). Bezpartyjność w powolnym odwrocie. Analiza rozpowszechnienia bezpartyjności w wyborach lokalnych w Polsce w latach 2002-2010. Studia Regionalne i Lokalne, 1(47), pp. 102-121.

Gendźwiłł, A., \& Żółtak, T. (2014). Why do non-partisans challenge parties in local politics? The (extreme) case of Poland. Europe-Asia Studies, 66(7), pp. 1122-1145.

Gentzkow, M., Shapiro, J. M., \& Sinkinson, M. (2011). The Effect of Newspaper Entry and Exit on Electoral Politics. American Economic Review, 101, pp. 2980-3018, DOI: 10.1257/aer.101.7.2980.

Gesthuizen, M., Van der Meer, T., \& Scheepers, P. (2009). Ethnic diversity and social capital in Europe: tests of Putnam's thesis in European countries. Scandinavian Political Studies, 32(2), pp. 121-142.

Głowacka, E. (2011). Badania wartości ekonomicznej usług biblioteczno informacyjnych i ich wpływu na otoczenie, Biblioteka, 15(54), pp. 217-230. 
Głuszczak, Z. (2001)., Maturzyści z Paczkowa. Rocznik 1951. Opowieść o uczniach jednej klasy, Urząd Miejski w Paczkowie.

'Gmina' (2017). Gmina w programie - podsumowanie, Tygodnik Krapkowicki, nr $45,07.11$.

Golka, M. (2010). Imiona Wielokulturowości. Warszawa: Wydawnictwo Literackie Muza.

Górski E. (2003). Rozważania o społeczeństwie obywatelskim $i$ inne studia z historii idei, Warszawa: Instytut Filozofii i Socjologii PAN.

Grodecka, B. (1980). Starzenie się i starość demograficzna ludności województwa opolskiego w latach 1950-1977. Studia Ślaskie, 37, pp. 171-190.

Grzywa, M. (2008). Ewaluacja - krótki przegląd definicji. In: Ewaluacja w samorzadzie lokalnym - perspektywy i możliwości. Kraków: FRDL/MISTiA.

Habuda, A., \& Habuda, L. (2014). Zasadniczy podział terytorialny państwa. Między racjonalnym wyborem i grą zinstytucjonalizowanych interesów. Wrocławskie Studia Politologiczne, 16, pp. 24-41.

Halamska, M. (2013). Wiejska Polska na początku XXI wieku. Rozważania o gospodarce i społeczeństwie. Warszawa: Wydawnictwo Naukowe Scholar.

Hanszke, E. (2018). Ponad 16 tys. cudzoziemców pracuje obecnie legalnie w województwie opolskim. Większość to Ukraińcy. https://nto.pl/ponad16-tysiecy-cudzoziemcow-pracuje-obecnie-legalnie-w-wojewodztwieopolskim-wiekszosc-to-ukraincy/ar/13452861 (Accessed 4 March 2019).

Hausner, J., Mazur, S. (2016). Zakończenie. In: J. Hausner, B. Jessop, S. Mazur (eds.), Governance. Wybór tekstów klasycznych, Warszawa: Wydawnictwo Naukowe SCHOLAR.

Herbst, J. (2005). Oblicza społeczeństwa obywatelskiego, Warszawa: Fundacja Rozwoju Społeczeństwa Obywatelskiego.

Hofstede, G., Hofstede, G. J., \& Minkov, M. (2011). Kultury i organizacje. Zaprogramowanie umystu. Warszawa: Polskie Wydawnictwo Ekonomiczne.

Honka, N. (2014). Is a New Administrative Division Reform Necessary? A Voice in the Discussion on Self-Government Reform. Srodkowoeuropejskie Studia Polityczne, 3, pp. 169-183.

Hooghe, M., Reeskens, T., Stolle, D., \& Trappers, A. (2009). Ethnic diversity and generalized trust in Europe: A cross-national multilevel study. Comparative Political Studies, 42(2), 198-223.

Ipsos MORI (2010). Voting by Newspaper Readership 1992-2010, Retrieved 12 September 2017 from: https://www.ipsos.com/ipsos-mori/en-uk/ voting-newspaper-readership-1992-2010. 
Jacher, W. (1991). Miejsce i rola ludności rodzimej w społecznościach lokalnych (na przykładzie Śląska Opolskiego). Studia Śląskie, L, pp. 25-38.

Jacher, W. (1994). Z doświadczeń badawczych nad integracją społeczną na Śląsku Opolskim. In: M. Lis (ed.), Ślask Opolski. Nadzieje i zagrożenia demokratycznych przemian, Opole: Instytut Nauk Społecznych Uniwersytetu Opolskiego, pp. 14-22.

Janowski, A. (2017). Opolska Platforma Obywatelska wybrała nowe władze. Nowa Trybuna Opolska, 11.12.2017.

Jeffery, C. (Ed.). (2015). The regional dimension of the European Union. London: Routledge.

Jessop, B. (2016). Narodziny wspótzarządzania i ryzyka jego zawodności: przypadek rozwoju gospodarczego, In: J. Hausner, B. Jessop, S. Mazur (eds.), Governance. Wybór tekstów klasycznych, Warszawa: Wydawnictwo Naukowe SCHOLAR.

'Jest' (2015). Jest nowy sołtys, Tygodnik Krapkowicki, 6, 10.02.

Jończy, R., \& Łukaniszyn-Domaszewska, K. (2014). Wpływ ludności pochodzenia niemieckiego oraz organizacji mniejszości niemieckiej na regionalny rozwój społeczno - gospodarczy. Gliwice-Opole: Dom Współpracy Polsko-Niemieckiej.

Jończy, R., \& Rokita-Poskart, D. (2013a). Fiscal Effects of Migration as a Factor Increasing Disparities in Local and Regional Development - An Example of the Opole Voivodeship in Poland. Economic and Environmental Studies, 13(1 (25)), pp. 9-21.

Jończy, R., \& Rokita-Poskart, D. (2013b). Zmiany w zatrudnieniu mieszkańców województwa opolskiego po akcesji Polski do Unii Europejskiej w świetle badań empirycznych. Studia Ekonomiczne, 134, pp. 94-102.

Jończy, R., \& Rokita-Poskart, D. (2014). Zmiany w zakresie zatrudnienia w Polsce i za granicą ludności autochtonicznej województwa opolskiego w okresie 2004-2010. Studia Ekonomiczne, 196, pp. 145-157.

Kachniarz, M., \& Babczuk, A. (2014). Ocena podziału terytorialnego państwa z uwzględnieniem efektywności funkcjonowania urzędów organów jednostek samorządu terytorialnego - wnioski i rekomendacje (expertise). Retrieved 13 January 2019 from: https://www.nist.gov.pl/files/zalacznik/1452372230_ ocenpodzia\%C5\%82u.pdf

Kaczmarek, T. (2016). Gminny podział administracyjny w świetle 25 lat funkcjonowania samorządu terytorialnego w Polsce „Przegląd Politologiczny", nr 1.

Kamusella, T. (1999). Ethnic Cleansing in Silesia 1950-1989 and the Ennationalizing Policies of Poland and Germany. Patterns of Prejudice, 33(2), pp. 51-73. 
Kaufmann, D., Kraay, A., \& Mastruzzi, M. (2007). Governance Matters VI: Governance Indicators for 1996-2006. World Bank Policy Research Working Paper No. 4280.

Kaufmann, D., Kraay, A., \& Mastruzzi, M. (2010). The Worldwide Governance Indicators: Methodology and Analytical Issues. World Bank Policy Research Working Paper, 5430.

Kemp, B., Jimenez, M. (2013). State of Local Democracy Assessment Framework. Stockholm: International Institute for Democracy and Electoral Assistance.

Khan, H. (2016). The Idea of Good Governance and the Politics of the Global South. An Analysis of Its Effects. New York - London: Routledge.

Kisielewicz, D. (2015). Historyczne uwarunkowania odrębności regionu Śląska Opolskiego. Pogranicze. Polish Borderlands Studies, 3(1), pp. 7-18. https:// doi.org/10.25167/ppbs493.

Kliszewski, S. (2018). Mocne wejście niezależnych, Nowiny Krapkowickie, 20.03: http://nowinykrapkowickie.pl/w/mocne-wejscie-niezaleznych

Kłoskowska, A. (1996). Kultury narodowe u korzeni. Warszawa: PWN.

Kobielska, K., \& Lisowska, A. (eds.). (2013). Standardy dobrego rządzenia w gminach małych. Teoria i praktyka. Bydgoszcz-Wrocław: Oficyna Wydawnicza Edward Mitek.

Kobielska, K., \& Lisowska, A. (eds.). (2014). Dobre rządzenie w gminach matych: empiryczny wymiar nowego paradygmatu rozwoju. Vol. 1, Bydgoszcz: Oficyna Wydawnicza Edward Mitek.

Kokot, J. (1973). Problemy narodowościowe na Ślasku od X do XX wieku. Opole: Instytut Śląski.

Koopmans, R., Schaeffer, M. (2016). Statistical and perceived diversity and their impacts on neighborhood social cohesion in Germany, France and the Netherlands. Social Indicators Research, 125(3), 853-883.

Korbel, J. (1990). Niektóre aspekty emigracji z Polski do RFN w pierwszej połowie lat osiemdziesiątych. Studia Śląskie, 49, pp. 121-134.

Kosmala, G. (2005). Rola pomników narodowych dla tożsamości mieszkańców Śląska Opolskiego. In: J. Haubold-Stolle, B. Linek (eds.), Górny Śląsk wyobrażony: wokół mitów, symboli i bohaterów dyskursów narodowych. OpoleMarburg: Wydawnictwo Instytut Śląski, Verlag Herder-Institut, pp. 267-288.

Kotlińska J. (2009). Dochody własne jednostek samorządu terytorialnego w Polsce. Ruch Prawniczy, Ekonomiczny i Socjologiczny, 3, pp. 143-161.

Kowalski, Z. (1972). Niektóre czynniki kształtujące postawy polityczne autochtonów i repatriantów na Śląsku Opolskim w okresie od stycznia 1947 do sierpnia 1948. Studia Ślaskie, XXII, pp. 277-310. 
Kula, G. (2013). Mierniki jakości rządzenia na szczeblu centralnym, regionalnym i lokalnym. In: J. Wilkin (ed.), Jakość rzązenia w Polsce. Jak ja badać, monitorować i poprawiać, Warszawa: Wydawnictwo Naukowe SCHOLAR, pp. 280-297.

Kumlin, S., Rothstein, B. (2010). Questioning the new liberal dilemma: Immigrants, social networks, and institutional fairness. Comparative Politics, 43(1), 63-80.

Kurczewski, J. (2007). Self-Identification Structure in Opole Silesia and the Kashubia: A Comparative Analysis. Polish Sociological Review, 1, pp. 87-104.

Kurzawa, A. (2015). Proceduralna strona kontroli społecznej sprawowanej przez instytucje skarg i wniosków. Rocznik samorządowy, 4, pp. 226-244.

Kwaśniewski, K. (1968). Adaptacja i integracja kulturowa ludności Śląska po II wojnie światowej. Wrocław: Instytut Śląski w Opolu.

Kwiatek, A. (2015). O Śląsku wymyślonym i wyobrażonym, czyli o śląskoznawstwie w ponowoczesnej narracji. Pogranicze. Polish Borderlands Studies, 3(1), pp. 19-36. https://doi.org/10.25167/ppbs498.

Kwiatek, A. (2018). Wpływ badań śląskoznawczych na kształtowanie się środowiska politologicznego Uniwersytetu Opolskiego. Pogranicze. Polish Borderlands Studies, 6(3), pp. 187-210.

La Porta, R., Lopez-de-Silanes, F., Shleifer, A., \& Vishny, R. (1999). The quality of government. The Journal of Law, Economics, and Organization, 15(1), pp. 222-279.

Lieberman, E. S. (2005). Nested analysis as a mixed-method strategy for comparative research. American Political Science Review, 99(3), 435-452.

Lis, M. (1993). Ludność rodzima na Śląsku Opolskim po II wojnie światowej, 1945-1993. Opole: PIN-Instytut Śląski.

Lis, M. (1998). Historyczne uwarunkowania odrębności regionalnej Śląska Opolskiego. Śląsk Opolski, 29, pp. 5-9.

Lis, M. (2013). Śląsk Opolski w warunkach transformacji ustrojowej państwa od 1989 roku. Opole: PIN-Instytut Śląski.

Lisowska, A. (2014). Otwartość jako zasada dobrego rządzenia. In: Dobre rzadzenie w gminach małych: empiryczny wymiar nowego paradygmatu rozwoju. Vol. 1, eds. K. Kobielska, A. Lisowska, Bydgoszcz: Oficyna Wydawnicza Edward Mitek.

Łodziński, S. (2016). Etniczne „flagowania” rzeczywistości. Problemy wprowadzania dodatkowych nazw miejscowości w językach mniejszości narodowych w Polsce. Pogranicze. Studia Społeczne, XXVII, pp. 223-250. DOI: $10.15290 /$ pss.2016.27.01.15. 
Łojko, M. (2014). Pomoc społeczna wczoraj i dziś. Nowe wyzwania - stare problemy, Studia Ekonomiczne, 179, pp. 206-214.

Łopaciuk-Gonczaryk, B. (2013). Kapitał społeczny a dobre rządzenie. In: Jakość rzadzenia w Polsce. Jak ja badać, monitorować i poprawiać, ed. J. Wilkin. Warszawa: Wydawnictwo Naukowe SCHOLAR.

Łopaciuk-Gonczaryk, B., \& Hardt, Ł. (2013). Pomiar i bazy wskaźników dobrego rządzenia - omówienie i prezentacja wybranych wskaźników. In: Jakość rządzenia w Polsce. Jak ja badać, monitorować i poprawiać, ed. J. Wilkin. Warszawa: Wydawnictwo Naukowe SCHOLAR.

Madajczyk, P. (1996). Przyłączenie Śląska Opolskiego do Polski 1945-1948. Warszawa: ISP PAN.

Madajczyk, P. (2001). Niemcy polscy 1944-1989. Warszawa: Oficyna Naukowa.

Madajczyk, P. (2005). Obcość jako wyznacznik powstawania i funkcjonowania granic etniczno-narodowych na Górnym Śląsku. In: J. Haubold-Stolle, B. Linek (eds.), Górny Ślask wyobrażony: wokół mitów, symboli i bohaterów dyskursów narodowych. Opole-Marburg: Wydawnictwo Instytut Śląski, Verlag Herder-Institut, pp. 109-122.

Madajczyk, P., \& Berlińska, D. (2008). Polska jako państwo narodowe. Historia i pamięć. Warszawa-Opole: ISP PAN i PIN - Instytut Śląski.

Malarski, S. (1998). Struktura administracyjno-instytucjonalna województwa opolskiego jako rozwiniętego, pełnego regionu europejskiego. Śląsk Opolski, 29, pp. 93-106.

Małecka-Łyszczek, M. (2015). Wpływ koncepcji kontroli zarządczej na poprawę sprawności funkcjonowania struktur samorządu terytorialnego. W: Sprawne państwo. Systemowe zmiany w funkcjonowaniu polskiego samorządu terytorialnego, ed. M. Ćwiklicki. Kraków: Uniwersytet Ekonomiczny i Małopolska Szkoła Administracji Publicznej.

Malkusz, Ł. (2014a). Z Krystyną Hruzik, sołtysem Kromołowa, rozmawia Łukasz Malkusz, Tygodnik Krapkowicki, 3. 21.01.

Malkusz Ł. (2014b). Z Romanem Hytrykiem, sołtysem Straduni, rozmawia Łukasz Malkusz, Tygodnik Krapkowicki, 6, 11.02.2014.

Markowski, R., Kotnarowski, M., Wenzel, M., \& Żerkowska-Balas, M. (2014). Demokratyczny Audyt Polski, Centrum Studiów nad Demokracją, Warszawa, http://dap.swps.pl/?page_id=54 (Accessed 18 May 2019).

Marx, A. (2017). Z wójtem gminy Walce Bernardem Kubatą rozmawia Andrea Marx, Tygodnik Krapkowicki, 3, 17.01.

Maszkowska, A., \& Wenclik, A. (2014). Przepis na udane konsultacje społeczne, Fundacja Laboratorium Badań i Działań Społecznych "SocLab", Białystok 
2014, https://partycypacjaobywatelska.pl/wp-content/uploads/2015/06/ Publikacja-Przepis-na-udane-konsultacje_web.pdf (Accessed 18 May 2019). Mazurkiewicz, E. (2017b)., Legendy i opowieści paczkowskiego pogranicza czyli bigos dawnych wierzeń, prawdy i fantazji, Paczków.

Mazurkiewicz, M. (2015). Wielokulturowy Śląsk Opolski - perspektywa politologiczna. Pogranicze. Polish Borderlands Studies, 3(1), pp. 83-101.

Mazurkiewicz, M. (2017a). Partycypacja mniejszości niemieckiej w polskim życiu publicznym po 1989 r. - przypadek Śląska Opolskiego. Rocznik Ziem Zachodnich, 1, pp. 143-164.

Miczka, P. (2006). Historia i wspótczesność gminy Walce, Urząd Gminy Walce.

Mihajlović, J. (2014). The discursive construction of regional development policy of the North Bačka region, Serbia. Regional Studies, Regional Science, 1(1), pp. 269-275.

Milner, H. (2002). Civic literacy: How informed citizens make democracy work. London and Hannover.

'Młodzież' (2017). Młodzież rządzi. Nowiny Nyskie,r 16, p. 16.

Montalvo, J. G., \& Reynal-Querol, M. (2002). Why ethnic fractionalization? Polarization, ethnic conflict and growth. Economics Working Papers 660.

Montalvo, J. G., \& Reynal-Querol, M. (2005). Ethnic polarization, potential conflict, and civil wars. American Economic Review, 95(3), 796-816.

Morga, M., Bak, D. (2012). Gmina Domaszowice, Urząd Gminy Domaszowice.

'Musieliśmy' (2016). Musieliśmy oszczędzać. Nowiny Nyskie, 4.

Naurin, D., \& Lindstedt, C. (2005). Transparency and Corruption. The Conditional Significance of a Free Press. Quality of Government Institute, Working Paper 5, University of Gothenburg.

Newton, K. (2001). Trust, social capital, civil society and democracy. International Political Science Review, vol. 22, no. 2.

Niedośpiał, J. (2013). Rady młodzieżowe w gminach i powiatach województwa małopolskiego, Fundacja Stańczyka, 25.02. http://www.stanczyk.org.pl/ otwarte-dane/ (Accessed 18 May 2019).

Nijakowski, L. (ed.). (2004). Nadciagają Śląacy. Czy istnieje narodowość ślaska? Warszawa: Scholar.

OECD (2012). PISA 2012 results in focus. What 15-year-olds know and what they can do with what they know, Retrieved 13 September 2017 from: http:// www.oecd.org/pisa/keyfindings/pisa-2012-results-overview.pdf.

Offe, C. (2016). Governance - „puste pojęcie” czy naukowy program badawczy. In: Governance. Wybór tekstów klasycznych, eds. J. Hausner, B. Jessop, S. Mazur. Warszawa: Wydawnictwo Naukowe SCHOLAR. 
Ogiolda, K. (2018). XXVII Festiwal Chórów i Zespołów Mniejszości Niemieckiej w Walcach, „Nowa Trybuna Opolska”, 25.11: https://nto.pl/ xxvii-festiwal-chorow-i-zespolow-mniejszosci-niemieckiej-w-walcach/ ar/13692296 (Accessed 12 July 2019).

Opioła, W. (2014a). Historyczna tożsamość pogranicza. Badanie politycznych funkcji pomników w województwie opolskim. Studia Ślaskie, (75), pp. 191-205.

Opiola, W. (2014b). About the role of the state border in the theory of border land. In: W. Chlebda (ed.), Open Europe: Cultural dialogue across borders, 2, Opole: Wydawnictwo Uniwersytetu Opolskiego, pp. 27-35.

Opioła, W. (2015). Pamięć zbiorowa i tożsamość historyczna lokalnej społeczności pogranicza. In: W. Chlebda, I. Dobrotová, (ed.), Pograniczność i pogranicza w perspektywie nauk społecznych. Opole: Wydawnictwo Uniwersytetu Opolskiego.

Opioła, W. (2017). Diagnoza wspótpracy pomiędzy administracja publiczna a trzecim sektorem w województwie opolskim, Opole: Stowarzyszenie Europa Iuvenis; Retrieved 14 September 2017 from: https://depot.ceon.pl/ handle/123456789/12723.

Opioła, W. (2019). Wpływ zróżnicowania narodowościowego na poziom kapitału społecznego lokalnej wspólnoty. Badanie porównawcze w wybranych gminach województwa opolskiego. Studia Regionalne i Lokalne, 75(1), pp. 52-70.

Opioła, W., \& Trzcielińska-Polus, A. (2013). Fenomen pograniczy. Pogranicze. Polish Borderlands Studies, 1(1), pp. 6-11.

'Owacje' (2015). Owacje dla sołtysa, Tygodnik Krapkowicki, 7, 17.02.

Paczkowska' (2013). Paczkowska Karta Turystyczna jest hitem. Nowa Trybuna Opolska, 08.11: https://nto.pl/paczkowska-karta-turystyczna-jest-hitem/ ar/4588035 (Accessed 17 September 2018).

Paasi, A. (2013). Regional Planning and the Mobilization of 'Regional Identity': From Bounded Spaces to Relational Complexity'. Regional Studies, 47, pp. 1206-1219.

'Paczków' (2002). Paczków. Wieczne miasto. Paczków: Ośrodek Kultury i Rekreacji.

'Paczków-Einbeck' (2002). Paczków-Einbeck - 10 lat współpracy. Głos Paczkowa, 83, p. 4.

'Paczków też' (2014). Paczków też będzie miał budżet obywatelski, Nowa Trybuna Opolska, 13.10: https://nto.pl/paczkow-tez-bedzie-mial-budzetobywatelski/ar/4636839 (Accessed 15 July 2018). 
PAP (2012). Opolskie - pierwsza rolnicza biogazownia w regionie, WNP.pl, https://www.wnp.pl/energetyka/opolskie-pierwsza-rolnicza-biogazownia-wregionie,180865.html (Accessed 21 April 2018).

Pattie, C. J., \& Johnston, R. J. (2003). Civic Literacy and Falling Electoral Turnout: The United Kingdom 1992-1997, Canadian Journal of Political Science. 36(3), pp. 579-599, DOI: 10.1017/S0008423903778779.

Pérez-Díaz, V. (1996). Powrót społeczeństwa obywatelskiego w Hiszpanii, Kraków.

Perkowski T. (2011). Mechanizm jednego procentu jako „fałszywa” filantropia, “Trzeci Sektor" no. 24.

Piechota, G. (2010). Motywacje Polaków przy wyborze organizacji pożytku publicznego (której przekazują $1 \%$ podatku) a budowanie lokalnej społeczności obywatelskiej, „Zarządzanie Publiczne” 13(3), pp. 5-17.

Pietraszko-Furmanek, I. (2012). Partycypacja społeczna $w$ środowiskach lokalnych. Kraków: Oficyna Wydawnicza AFM.

Podgórniak-Krzykacz, A. (2013). Dobre rządzenie w teorii i praktyce strategicznego zarządzania publicznego w regionach. Studia Ekonomiczne. Zeszyty Naukowe Uniwersytetu Ekonomicznego w Katowicach, 169, pp. 168-179.

Popiel, S. (2017), Dzień seniora w stolicy, Paczków.pl: http://paczkow.pl/1554/ dzien-seniora-w-stolicy.html (Accessed 15 July 2018).

Portes, A. (1998). Social capital: Its origins and applications in modern sociology. Annual review of sociology, 24(1), 1-24.

Portes, A., Vickstrom, E. (2011). Diversity, social capital, and cohesion. Annual review of sociology, 37, 461-479.

Porycka, D. (2016). Waga inwestycji. Ekspert o różnym stopniu otwartości gmin na działania rozwojowe. http://samorzad.pap.pl/depesze/polecane. kadry/170652/Waga-inwestycji--Ekspert-o-roznym-stopniu-otwartoscigmin-na-dzialania-rozwojowe (Accessed 20 May 2019).

Posner, D. N. (2004). Measuring ethnic fractionalization in Africa. American journal of political science, 48(4), pp. 849-863.

Przewłocka, J., Adamiak, P., Herbst, J.(2013). Podstawowe fakty o organizacjach pozarzadowych Raport z badania 2012. Warszawa: Stowarzyszenie Klon Jawor.

Putnam, R. (1995). Demokracja $w$ działaniu. Kraków: Społeczny Instytut Wydawniczy Znak.

Putnam, R. (1997). Demokracja w działaniu, Kraków: Wydawnictwo Znak.

Putnam, R. (2001). Bowling alone: The collapse and revival of American community. Simon and Schuster. 
Putnam, R. D. (2007). E pluribus unum: Diversity and community in the twenty-first century the 2006 Johan Skytte Prize Lecture. Scandinavian Political Studies, 30(2), pp. 137-174.

Putnam, R. D. (2008). Samotna gra w kręgle: upadek i odrodzenie wspólnot lokalnych w Stanach Zjednoczonych. Warszawa: Wydawnictwa Akademickie i Profesjonalne.

Rajman, J. (2003). Trwałość przemysłowo-osadniczych układów przestrzennych w starym rejonie przemysłowym (przykład dorzecza Małej Panwi). Studies of the Industrial Geography Commission of the Polish Geographical Society, 4, pp. 37-42.

Rauziński R., \& Szczygielski, K. (2013). Współczesne problemy demograficzne śląska opolskiego, Instytut Śląski: Opole.

Rauziński, R. (1982). Z badań nad migracjami zewnętrznymi ludności Śląska Opolskiego w latach 1950-1980. Studia Ślaskie, vol. XL, pp. 241-271.

Rauziński, R. (1986). Społeczeństwo Śląska Opolskiego 1945-1985 (ludność, zatrudnienie, migracje). Opole: Wyższa Szkoła Inżynierska.

Rauziński, R. (1998). Odrębność demograficzna Opolszczyzny. Ślask Opolski, special issue 29, pp. 24-29.

Rauziński, R. (2007). Zastosowanie metody taksonomicznej do oceny rozwoju i zróżnicowania przestrzennego sytuacji społeczno-demograficznej powiatów, miast i gmin województwa opolskiego w 2002 roku. In: Z. M. Nowak, R. Rauziński (eds.), Śląsk 2020. Czynniki i strategie rozwoju. Opole: Wydawnictwa WSZiA; Wydawnictwo Instytut Śląski, pp. 185-199.

'Rewolucja' (2017). Paczków: Rewolucja w centrum miasta. Nowiny Nyskie, 47, p. 16.

Reynal-Querol, M. (2002). Ethnicity, political systems, and civil wars. Journal of Conflict Resolution, 46(1), pp. 29-54.

Riding, J., \& Jones, M. (eds.). (2017). Reanimating Regions: Culture, Politics, and Performance. New York-Abingdon: Taylor \& Francis.

Rohlfing, I. (2008). What you see and what you get: Pitfalls and principles of nested analysis in comparative research. Comparative Political Studies, 41(11), 1492-1514.

'Rolnicy' (2015). Rolnicy na czele, Tygodnik Krapkowicki, 14.04, nr 15.

ROPS (2014). Kontrakt socjalny w praktyce. Raport z badania przeprowadzonego w województwie opolskim. Opole: Obserwatorium Polityki Społecznej, http://ois.rops-opole.pl/download/KONTRAKT\%20 SOCJALNY-\%20raport.pdf (Accessed 18 May 2019).

ROPS (2016a). Stopień zagrożenia ubóstwem w woj. opolskim. Wielowymiarowa analiza porównawcza opracowana na podstawie metody 
wzorca rozwoju. Opole: Obserwatorium Polityki Społecznej, http://www.ois. rops-opole.pl/index.php?id=30 (Accessed 18 May 2019).

ROPS (2016b). Ocena zasobów pomocy społecznej województwa opolskiego w 2015 roku, Opole: Obserwatorium Polityki Społecznej,www.ois.rops-opole. pl/download/OZPS\%202015.pdf (Accessed 18.05.2019).

Rose-Ackerman, S. (2001). Korupcja i rzady, Warszawa: Fundacja im. Stefana Batorego.

Rothstein, B. (2011). The quality of government. Corruption, social trust and inequality in international perspective. Chicago: The University of Chicago Press.

Rothstein, B., Charron, N. (2014). Social trust, quality of government and ethnic diversity. An empirical analysis of 206 regions in Europe. Gothenburg: Quality of Government Institute.

Rykała, A. (2014). Mniejszości narodowe i etniczne w Polsce z perspektywy geografii politycznej. Acta Universitatis Lodziensis. Folia Geographica SocioOeconomica 17, pp. 63-111.

Rykała, A., \& Sobczyński, M. (2016). Naród polski jako żywa struktura. Kształtowanie się poczucia odrębności narodowej Ślązaków pod wpływem uwarunkowań geograficzno-historycznych i geograficzno-politycznych. Studia z Geografii Politycznej i Historycznej, 5, pp. 133-176.

Rymsza, M. (2014). Polityka aktywizacji i programy reintegracyjne w Polsce, in: Reintegracja. Aktywna polityka społeczna w praktyce, eds. A. Karwacki, T. Kaźmierczak, M. Rymsza, Instytut Spraw Publicznych, Warszawa, pp. 137-170.

Sampson, S. (2010). The anti-corruption industry: from movement to institution. Global Crime, 11(2), pp. 261-278.

Schaeffer, M. (2013). Ethnic diversity, public goods provision and social cohesion: Lessons from an inconclusive literature (No. SP VI 2013-103). WZB Discussion Paper.

Seawright, J., \& Gerring, J. (2008). Case selection techniques in case study research: A menu of qualitative and quantitative options. Political research quarterly, 61(2), pp. 294-308.

Simonides, D. (1998). Dlaczego Śląsk Opolski jest odrębnym regionem. Śląsk Opolski, 29, pp. 87-92.

Skrzypiec, R. (2002). Badanie lokalnej aktywności obywatelskiej. In: Lokalne uczestnictwo obywatelskie, eds. R. Skrzypiec, P. Frączak. Warszawa: Asocjacje.

Skrzypiec, R. (2013). Wspieranie rozwoju społeczeństwa obywatelskiego $w$ regionach. Warszawa: Biblioteka Pożytku Publicznego. 
Śmiełowska, M. (1991). Kulturowe uwarunkowania stosunków społecznych w zbiorowościach lokalnych województwa opolskiego. Studia Śląskie, 50, pp. 53-70.

Sokołowski, D. (2014). Niektóre uwarunkowania korekty podziału Polski na województwa. Przegląd Geograficzny, 86(4), pp. 567-590.

Solga, B. (2002). Migracje polsko-niemieckie i ich konsekwencje społeczno-ekonomiczne na obszarach wiejskich Ślaska Opolskiego. Opole: Stowarzyszenie Instytut Śląski w Opolu i Dom Współpracy Polsko-Niemieckiej.

Sołdra-Gwiżdż, T. (1997). Między rzeczywistościa lokalna i regionalną. Wybrane instytucje społeczne Śląska Opolskiego. Opole: Państwowy Instytut Naukowy Instytut Śląski w Opolu.

Starczewski, B. (2009). Konsultacje z mieszkańcami gminy, „Samorząd.

Lex" 13.05, http://www.samorzad.lex.pl/czytaj/-/artykul/konsultacje-zmieszkancami-gminy (Accessed 18 May 2019).

Starzyk, K. (2014). ZOOM na rady seniorów. Diagnoza funkcjonowania, Pracownia Badań i Inicjatyw Społecznych Stocznia, https://stocznia.org.pl/ publikacje/zoom-na-rady-seniorow-diagnoza-funkcjonowania/ (Accessed 19 May 2019).

Staśkiewicz, J. (2015)., Jak Domaszowice zagłosowały w 104 \%, „Nowa Trybuna Opolska", 23.01: http://www.nto.pl/magazyn/reportaz/art/4651786,jakdomaszowice-zaglosowaly-w-104-procentach,id,t.html (Accessed 21 April 2018).

Staśkiewicz, J. (2017)., Jest akt oskarżenia przeciwko wójtowi gminy Domaszowice, „Nowa Trybuna Opolska”, 13.04: https://nto.pl/jest-aktoskarzenia-przeciwko-wojtowi-gminy-domaszowice/ar/11983862 (Accessed 21 April 2018).

Stecki, K. (2001). Rowerem przez Opolszczyznę. https://nto.pl/rowerem-przezopolszczyzne/ar/3942533 (Accessed 2 June 2019).

Steinborn, B. (1982), Otmuchów. Paczków, Wrocław: Ossolineum.

'Strategia' (2012). Strategia Rozwoju Województwa Opolskiego do 2020 roku. Opole: Urząd Marszałkowski Województwa Opolskiego.

'Strategy' (2007). Strategy for Innovation and Good Governance at local level Extract from the Valencia Declaration 15th Conference of European Ministers responsible for local and regional government (2007). Appendix I, Council of Europe, Valencia, 15-16 October.

Strauchman, K. (2014). Kampania w cieniu odchodzącego burmistrza, Nowa Trybuna Opolska, 13 October. 
Strauchold, G. (2005). Historiografia III Rzeczypospolitej wobec zagadnień Śląska Opolskiego po II wojnie światowej. Zarys problematyki. Studia Śląskie, LXIV, pp. 15-28.

Sturgis, P., Brunton-Smith, I., Read, S., Allum, N. (2011). Does ethnic diversity erode trust? Putnam's 'hunkering down'thesis reconsidered. British Journal of Political Science, 41(1), 57-82.

Swianiewicz, P. (2010). Czy rozmiar ma znaczenie? Zróżnicowanie opinii mieszkańców o funkcjonowaniu samorządów lokalnych w zależności od wielkości gminy, Samorząd Terytorialny, 4, 2010, pp. 5-16.

Swianiewicz, P. (2014). An empirical typology of local government systems in Eastern Europe. Local Government Studies, 40(2), pp. 292-311.

Swianiewicz, P. (2014a). Ocena podziału terytorialnego państwa z uwzględnieniem efektywności funkcjonowania urzędów organów jednostek samorządu terytorialnego -wnioski i rekomendacje (expertise). Retrieved 01.06.2019 from: https://www.nist.gov.pl/files/zalacznik/1452372160 Ocena\%20podzialu\%20teryt-ekspertyza\%20prof\%20Swianiewicz.pdf

Swianiewicz, P. (2017). Co dalej z samorzadem? Uwagi do programu Platformy Obywatelskiej. Warszawa: Fundacja im. Stefana Batorego.

Swianiewicz P., \& Klimska, P. (2003). Kto rządzi gminą i jak? Lokalni liderzy polityczni w teorii i praktyce samorządów lokalnych, Studia Regionalne $i$ Lokalne, 14(4), pp. 15-40.

Swianiewicz, P., \& Łukomska, J. (2014). Oszczędny urząd. Ranking wydatków na administracje - 2014 r., Wspólnota, http://www.wspolnota.org.pl/ aktualnosci/aktualnosc/zwalniali-czyli-beda-przyjmowac-rankingwydatkow-na-administracje/ (Accessed 20 May 2019).

Szacki, J. (selection of texts and introduction) (1997). Ani książę ani kupiec: obywatel. Kraków-Warszawa: Znak.

Szacki, J. (1997). O narodzie i nacjonalizmie. Znak, 3, pp. 4-31.

Szacki, J. (1997). Wstęp. Powrót idei społeczeństwa obywatelskiego. In: Szacki, J., (selection of texts and introductions) Ani książę ani kupiec: obywatel. Kraków-Warszawa: Znak.

Szczerbaniewicz, B. (2011)., Krapkowice. Mniejszość z Platformą na wojennej ścieżce, Nowa Trybuna Opolska, 25.02 https://nto.pl/ krapkowice-mniejszosc-z-platforma-na-wojennej-sciezce/ar/4179821.

Szczerbaniewicz, B. (2015)., Jaki jest naprawdę szyld mniejszości?, Tygodnik Krapkowicki, 36, 08.09.

Szczerbaniewicz, B. (2015a)., UKS ma prześwietlić oświadczenia, Tygodnik Krapkowicki, nr 48, 01.12. 
Szczerbaniewicz B. (2018), Kto na burmistrza? Kto na wójta?, Tygodnik Krapkowicki, 21.08. nr 34.

Szczerbaniewicz, B. (2018a)., Niemcy stawiają na Śmiecha, Tygodnik Krapkowicki, 15.05, nr 20.

Szczerbaniewicz, B. (2018b). Żadnej pracy się nie boję, Z Markiem Śmiechem, dyrektorem GOK w Walcach rozmawia Beata Szczerbaniewicz, Tygodnik Krapkowicki, 17.04., nr 16.

Szczepański, M.S. (1998). Regionalizm górnośląski: między plemiennością a systemem globalnym. In: A. Sułek, M.S. Szczepański (eds.), Śląsk-PolskaEuropa. Zmieniające się społeczeństwo w perspektywie lokalnej i globalnej. Katowice: Wydawnictwo Uniwersytetu Śląskiego, pp. 17-39.

Sześciło, D. (2016). Polski samorząd na tle europejskim. Mocne i słabe strony, najważniejsze wyzwania, Fundacja Batorego, Warszawa: https://www. maszglos.pl/wp-content/uploads/2016/03/Polski-samorzad-na-tleeuropejskim_Dawid-Szescilo_Fundacja-im.-S.Batorego.pdf (Accessed 23 November 2018).

Sześciło, D. (2018). Nowe narzędzia dla obywateli i radnych $w$ samorzadzie, Fundacja im. Stefana Batorego, Warszawa: https://www.maszglos.pl/ aktualnosci/nowe-narzedzia-dla-obywateli-i-radnych-w-samorzadzie/ (Accessed 22 October 2018).

Szmeja, M. (1997). Starzy i nowi mieszkańcy Opolszczyzny. Opole: PIN-Instytut Śląski w Opolu.

Szmeja, M. (2000). Niemcy? Polacy? Ślązacy! Kraków: Universitas.

Szmeja, M. (2017). Ślask - bez zmian (?) Ludzie, kultura i społeczność Śląska w perspektywie postkolonialnej. Kraków: Nomos.

Szypowska, M. (1965), Paczków, Warszawa: SiT.

tam (2014). Wyborcze klepsydry na Opolszczyźnie. „Tak walczyć nie należy”. Accessed 9 August 2019 at: https://www.tvn24.pl/wroclaw,44/wyborczeklepsydry-na-opolszczyznie-tak-walczyc-nie-nalezy,484494.html.

Transparency International (2009). The Anti-Corruption Plain Language Guide. Transparency International.

Trosiak, C. (2013). Dyskusja i spory wokół wprowadzania podwójnych nazw miejscowości na terenie Śląska Opolskiego. Przegląd Politologiczny, 2, pp. 149-162.

Trutkowski, C. (2016). Skuteczny urząd samorządowy. Rozwój kompetencji kadr jako element budowy sprawnej administracji lokalnej. Raport z badań zreazliowanych przez Fundację Rozwoju Demokracji Lokalnej. Warszawa: http://frdl.mazowsze.pl/pl/793-skuteczny_urzad_samorzadowy raport (Accessed 2 November 2018). 
Trutkowski, C. \& Mandes, S. (2005). Kapitat społeczny w małych miastach. Warszawa: Wydawnictwo Naukowe SCHOLAR.

Trzcielińska-Polus, A. (1999). Współpraca regionalna i lokalna Śląska Opolskiego z Niemcami na tle partnerstw polsko-niemieckich. Śląsk Opolski, 34, pp. 49-63.

Trzcielińska-Polus, A., \& Opioła, W. (2013). Fenomen pograniczy. Pogranicze. Polish Borderlands Studies, 1(1), pp. 6-11.

Vainikka, T.J. (2015). Reflexive Identity Narratives and Regional Legacies. Tijdschrift voor economische en sociale geografie, vol. 106, issue 5, pp. 503-520.

Wallman Lundåsen, S., \& Wollebæk, D. (2013). Diversity and community trust in Swedish local communities. Journal of Elections, Public Opinion \& Parties, 23(3), pp. 299-321.

Wilde, A., Narang, S., Laberge, M., \& Moretto, L. (2009). A Users' Guide to Measuring Local Governance. UNDP Oslo Governance Centre 2009. http:// www.undp.org/content/undp/en/home/librarypage/democratic-governance/ local_governance/a-users-guide-to-measuring-local-governance-.html (Accessed 29 June 2017).

Wilkin, J. (2008). Badanie dotyczace stworzenia system wskaźników dla oceny realizacji zasady good governance w Polsce. Raport końcowy. Warszawa: ECORYS Polska.

Wilkin, J. (2013). Kategoria jakości rządzenia w naukach społecznych zagadnienia metodologiczne. In: Jakość rządzenia w Polsce. Jak ja badać, monitorować i poprawiać, ed. J. Wilkin, Warszawa: Wydawnictwo Naukowe SCHOLAR.

Wiłkomirska, A., Wiedza obywatelska młodzieży w Polsce i na świecie komunikat $z$ badań międzynarodowych, Forum Oświatowe, 1/2011 (44), pp. 59-69.

Wojciechowski, E., \& Podgórniak-Krzykacz, A. (2008). Pomiar jakości rządzenia. Gospodarka Narodowa, no. 3, pp. 19-38.

Wojciechowski, E., Podgórniak-Krzykacz, A., Dolewka, Z., \& Wojciechowski, M. (2014). Samorząd terytorialny w Polsce - Raport. Łódź: Instytut Diagnoz i Analiz Społecznych.

Wojtowicz, D., \& Paciorek, K. (2012). Systemy i narzędzia zarządzania jakością $\mathrm{w}$ urzędach gmin a efektywne korzystanie z funduszy unijnych, Studia Regionalne i Lokalne, 48(2), pp. 5-19.

Wolniak, D. (2018). Z burmistrzem Paczkowa Arturem Rolką rozmawiamy o budżecie, dotacjach unijnych i najważniejszych inwestycjach w gminie. Nowiny Nyskie, 5, p. 16. 
Wright, M., \& Bloemraad, I. (2012). Is there a trade-off between multiculturalism and socio-political integration? Policy regimes and immigrant incorporation in comparative perspective. Perspectives on Politics, 10(01), pp. 77-95.

Yoder, J. A. (2003). Decentralisation and regionalisation after communism: administrative and territorial reform in Poland and the Czech Republic. Europe-Asia Studies, 55(2), pp. 263-286.

Żabiński, M. (2012). Samoocena systemu zarzadzania w jednostkach samorządu terytorialnego. Porównanie metody "Planowania Rozwoju Instytucjonalnego" $i$ “Wspólnej Metody Oceny CAF”, Zarządzanie Publiczne, 20(2), pp. 57-76.

Zaborowski, Ł. (2009). Podział terytorialny Rzeczypospolitej-spojrzenie krytyczne. Prace Geograficzne, 121, pp. 263-275.

Zawora, J. (2013). Samodzielność finansowa samorzadów gminnych w warunkach spowolnienia gospodarczego, Prace Naukowe Uniwersytetu Ekonomicznego we Wrocławiu, no. 306, pp. 523-533.

Ziółkowski, M. (2012). Kapitały społeczny, kulturowy i materialny i ich wzajemne konwersje. Studia Edukacyjne, 22, pp. 7-27.

Ziółkowski, R. (2014). Jak powiat zlikwidował ognisko artystyczne w Paczkowie, Nowiny Nyskie, 45, 2014, p. 6.

Żołnierczyk, E., Szumowski, W. (2014). Efektywność jako zasada dobrego rzadzenia. In: Dobre rzadzenie w gminach małych: empiryczny wymiar nowego paradygmatu rozwoju, Vol. 1, eds. K. Kobielska, A. Lisowska, Bydgoszcz: Oficyna Wydawnicza Edward Mitek.

'Zrewitalizują' (2017). Zrewitalizuja miasto, Nowiny Nyskie, 20.

Żurek, R. (2012)., Recepta na „długowieczność" wójta. Analiza czynników prowadzacych do reelekcji w wyborach $2010 \mathrm{r}$. na wybranych przykładach, „Prace Naukowe Akademii im. Jana Długosza”, wydanie specjalne.

Zygmunt, J., \& Mach, Ł. (2011). Zróżnicowanie wydatków inwestycyjnych w gminach powiatu kędzierzyńsko-kozielskiego, „Barometr Regionalny”, 26(4), pp. 67-74.

Zyzik, K. (2004). Aktyw od pługa, Nowa Trybuna Opolska, 16.01: http://www. nto.pl/magazyn/reportaz/art/3991973,aktyw-od-pluga,id,t.html. 


\title{
Studies in Politics, Security and Society
}

\author{
Edited by Stanisław Sulowski
}

Vol. 1 Robert Wiszniowski (ed.): Challenges to Representative Democracy. A European Perspective. 2015.

Vol. 2 Jarosław Szymanek: Theory of Political Representation. 2015.

Vol. 3 Alojzy Z. Nowak (ed.): Global Financial Turbulence in the Euro Area. Polish Perspective. 2015.

Vol. 4 Jolanta Itrich-Drabarek: The Civil Service in Poland. Theory and Experience. 2015.

Vol. 5 Agnieszka Rothert: Power of Imagination. Education, Innovations and Democracy. 2016.

Vol. 6 Zbysław Dobrowolski: Combating Corruption and Other Organizational Pathologies. 2017.

Vol. 7 Vito Breda: The Objectivity of Judicial Decisions. A Comparative Analysis of Nine Jurisdictions. 2017.

Vol. 8 Anna Sroka: Accountability and democracy in Poland and Spain. 2017.

Vol. 9 Anna Sroka / Fanny Castro-Rial Garrone / Rubén Darío Torres Kumbrián (eds.): Radicalism and Terrorism in the 21st Century. Implications for Security. 2017.

Vol. 10 Filip Pierzchalski: Political Leadership in Morphogenetic Perspective. 2017.

Vol. 11 Alina Petra Marinescu: The Discursive Dimension of Employee Engagement and Disengagement. Accounts of keeping and leaving jobs in present-day $\mathrm{Bu}-$ charest organizations. 2017.

Vol. 12 Jacek Giedrojć: Competition, Coordination, Social Order. Responsible Business, Civil Society, and Government in an Open Society. 2017.

Vol. 13 Filip Ilkowski: Capitalist Imperialism in Contemporary Theoretical Frameworks. 2017.

Vol. 14 Leszek Leszczyński / Adam Szot (eds.): Discretionary Power of Public Administration. Its Scope and Control. 2017.

Vol. 15 Tadeusz Klementewicz: Understanding Politics. Theory, Procedures, Narratives. 2017.

Vol. 16 Tomasz Bichta: Political Systems of the Former Yugoslavia. 2018

Vol. 17 Miroslav Palárik / Alena Mikulášová / Martin Hetényi / Róbert Arpáš: The City and Region Against the Backdrop of Totalitarianism. 2018

Vol. 18 Jolanta Itrich-Drabarek / Stanisław Mazur / Justyna Wiśniewska-Grzelak (eds.): Understanding Politics. Theory, Procedures, Narratives. 2017.

Vol. 19 Jerzy Juchnowski / R. Jan Sielezin / Ewa Maj: The Image of "White" and "Red" Russia in the Polish Political Thought of the 19th and 20th Century. Analogies and Parallels. 2017.

Vol. 20 Roman Kuźniar: Europe in the International Order. 2018.

Vol. 21 Piotr Jaroszynski: Europe - the Clash of Civilisations. 2018.

Vol. 22 Stanisław Filipowicz: Truth and the Will to Illusion. 2018.

Vol. 23 Andrzej Szeptycki: Contemporary Relations between Poland and Ukraine. The "Strategic Partnership" and the Limits Thereof. 2019. 
Vol. 24 Sylwester Gardocki / Rafał Ożarowski / Rafał Ulatowski (eds.): The Islamic World in International Relations. 2019.

Vol. 25 Jacek Zaleśny (ed.): Constitutional Courts in Post-Soviet States. Between the Model of a State of Law and Its Local Application. 2019.

Vol. 26 Andrzej Antoszewski / Przemysław Żukiewicz / Mateusz Zieliński / Katarzyna. Domagała: Formation of Government Coalition in Westminster Democracies. Towards a Network Approach. 2020.

Vol. 27 Joanna Osiejewicz : Global Governance of Oil and Gas Resources in the International Legal Perspective. 2020.

Vol. 28 Anita Oberda-Monkiewicz : Poland-Mexico towards a Strategic Partnership. 2020.

Vol. 29 Bartosz Czepil / Wojciech Opioła: Ethnic diversity and local governance quality. The case of Opole Province in Poland. 2020.

www.peterlang.com 